\title{
COSTUMING THE SHAKESPEAREAN STAGE: \\ VISUAL CODES OF REPRESENTATION \\ IN EARLY MODERN THEATRE AND CULTURE
}

\section{DISSERTATION}

\author{
Presented in Partial Fulfillment of the Requirements for \\ The Degree Doctor of Philosophy in the Graduate \\ School of The Ohio State University
}

By

Robert I. Lublin, A.M.

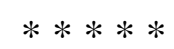

The Ohio State University

2003

Dissertation Committee:

Professor Thomas Postlewait, Adviser

Approved by

Associate Professor Christopher Highley

Associate Professor Alan Woods

Adviser

Theatre Graduate Program 
Copyright by

Robert I. Lublin 2003 


\begin{abstract}
This dissertation provides a two-part study: (1) an investigation of the visual codes governing clothing in early modern England, (2) an examination of the manner in which costumes were employed in the various theatrical venues of the period. Crucial to both of these considerations is an analysis of the social, economic, and political factors that influenced the clothing and costuming practices in English society.
\end{abstract}

In early modern England, clothing possessed the ability to define a person's identity and locate his or her position within multiple, overlapping cultural categories. The apparel a person wore established one’s sex, rank, occupation, nationality, and even religion. Taken together, one’s clothing served to produce an individual as a member and constituent of the body politic.

This dissertation has five chapters. The first establishes the visual codes governing clothing that maintained in early modern England. Looking at royal proclamations, paintings, woodcuts, plays, historical accounts, sermons, and legal documents, I piece together the means by which individuals were visually understood at the time. This information contributes to how theatre was experienced. For instance, looking at both the extensive sumptuary legislation passed by Queen Elizabeth and the evidence from the drama, I argue that actors on the London 
professional stages regularly wore costumes that visually asserted the social class of their characters to a high degree of specificity.

Chapter two examines the costumes employed in court masques. I argue that the visual presentation of the courtier-masquers had political implications that challenge current understandings of the elite entertainment. Chapter three explores the various ways that costumes were used by the professional theatre companies. Chapter four pursues an in-depth analysis of a single play, Middleton's A Game at Chess, to consider the site specific, historically contingent manner in which costumes were employed at the time. Chapter five elucidates the function that apparel served in the annual Lord Mayor's Shows in London.

This study of the visual codes employed in production serves as an analysis of the society that established its particular ways of dressing and seeing. "Costuming the Shakespearean Stage” articulates the complex manner in which costumes and apparel informed the substance, the staging, and the reception of performance in early modern England. 
Dedicated to my family 


\section{ACKNOWLEDGMENTS}

I would like to thank my advisor, Thomas Postlewait, for his guidance during the writing of this work and his mentorship throughout my time at OSU. His recommendations inform both the structure and the substance of this dissertation, and I feel truly lucky to have had the opportunity to study for three years with an advisor who is so dedicated to his graduate students.

Thanks also to Christopher Highley and Alan Woods who both responded to chapters during the writing process and contributed significantly to the development of my argument and to the clarity of its articulation.

I would also like to acknowledge the debt I owe to Lynn Morrow, my Theatre professor at Albright College, who taught me how to write and set me down the path that ultimately led to the successful completion of this dissertation.

Thanks to Lee Bleyer, William Heller, Brett Clifton, and Michael Jaros for their years of close friendship and support.

And last, I want to express my most sincere gratitude to my family. Their love and encouragement has played as large a role in the writing of this dissertation as any effort I put forward. I include in this a thank you to Karie Kirkpatrick whose support and love proved even more important to the completion of this work than the help she provided with the bibliography. 
VITA

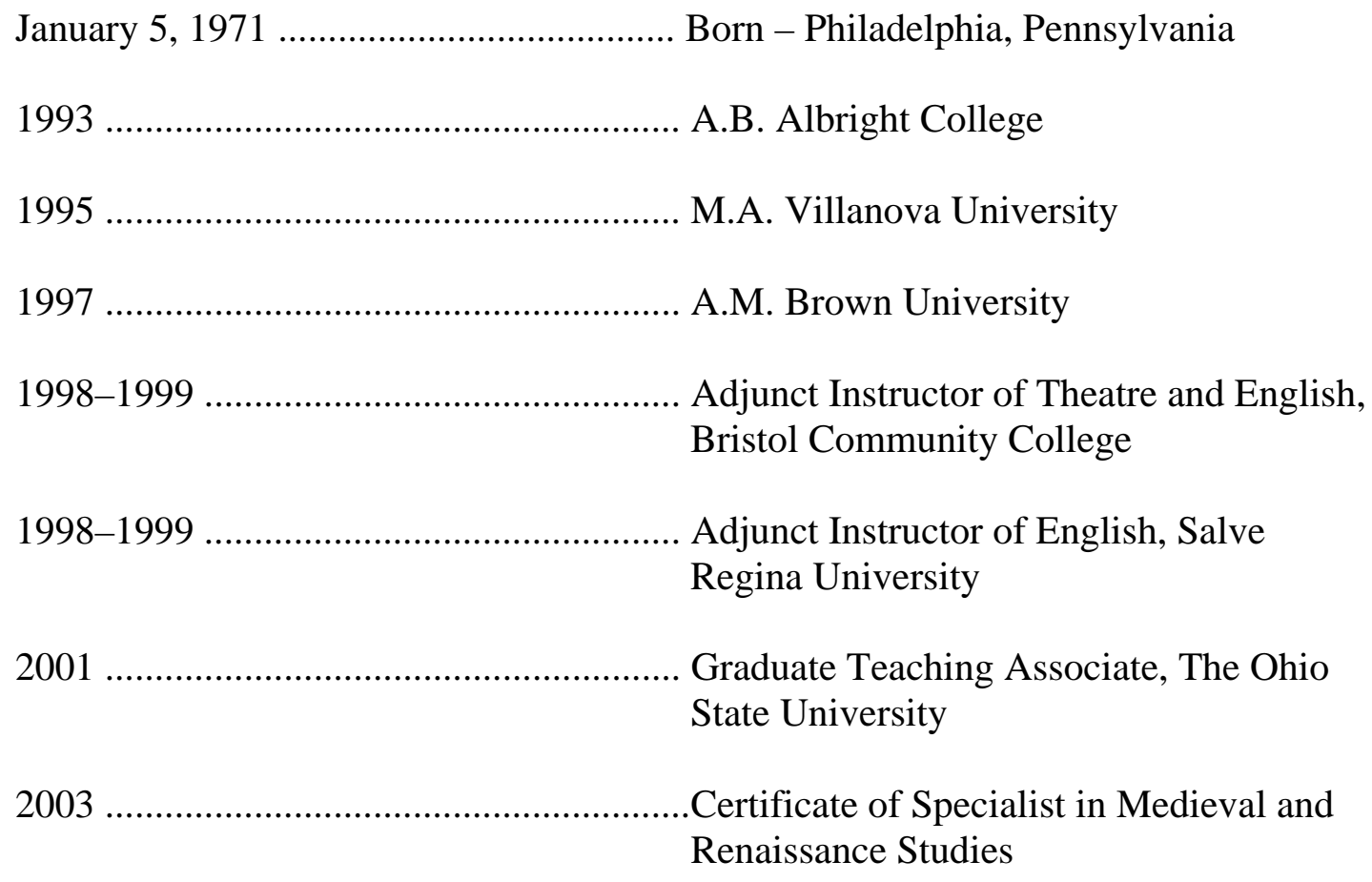

PUBLICATIONS

1. Lublin, Robert. "Performance Review of and...and...and by Chris Dickman, Ensemble Actors' Theatre, Madlab Theatre, Columbus, Ohio. 16-18 November 2001.” Theatre Journal 54.3 (2002): 494-6.

2. $\quad$ Lublin, Robert. “Unpublished Letters From Charles and Ellen Kean’s Final American Tour.” Theatre Notebook 55.2 (2001): 80-2.

3. Lublin, Robert. "Differing Dramatic Dynamics in the Stage and Screen Versions of Glengarry Glen Ross.” American Drama 10.1 (2001): 38-55. 
4. Lublin, Robert. "Book Review of Robert B. Graves’ Lighting the

Shakespearean Stage, 1567-1642.” Carbondale: Southern Illinois UP, 1999. Appears in Theatre Survey 42.1 (2001): 89-91.

5. Lublin, Robert. “Book Review of Michal Kobialka’s Of Borders and Thresholds: Theatre History, Practice, and Theory.” Minneapolis: U of Minnesota P, 1999. Appears in Theatre Studies 45 (2001): 96-99.

6. “Cadences of Cruelty: Artaud's Discursive Performance.” Theatre Symposium 8 (2000): 62-72.

7. “Edward Bond's 'Irresponsibly Optimistic' Preface to Saved.” Theatre Southwest 27 (1999): 1-8.

\section{FIELDS OF STUDY}

Major Field: Theatre

Minor Field: Medieval and Renaissance Studies 


\section{TABLE OF CONTENTS}

\section{Page}

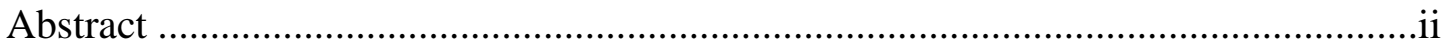

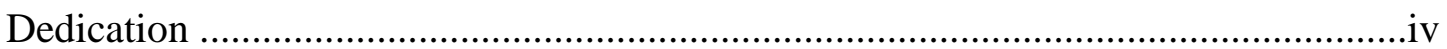

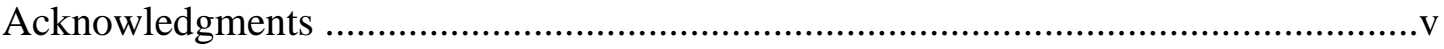

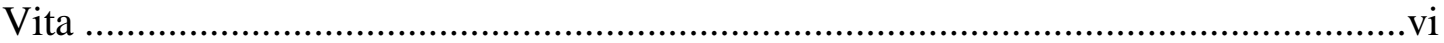

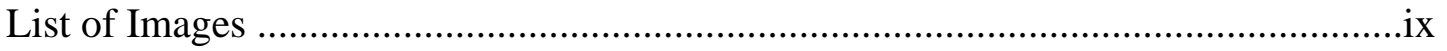

Chapters:

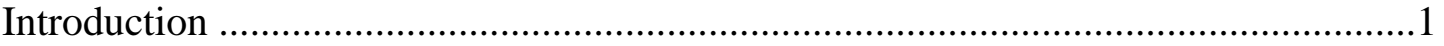

1. Visual Codes of Representation ..............................................................

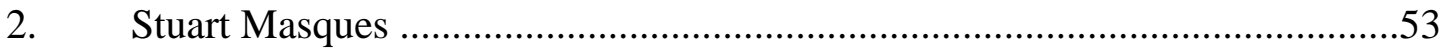

3. Playwrights and Professional Companies .......................................................89

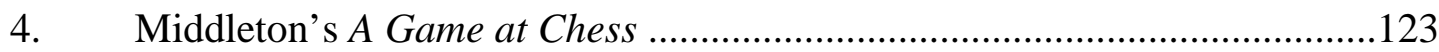

5. The Lord Mayor's Show ……………………..........................................152

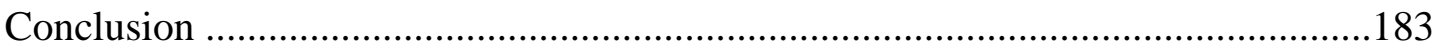

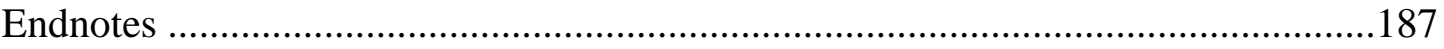

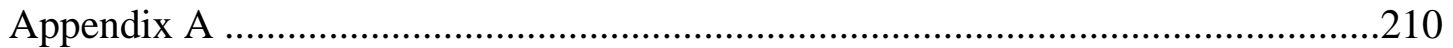

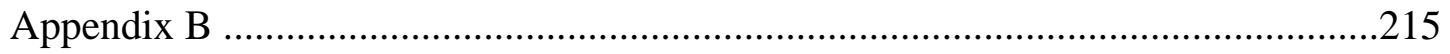

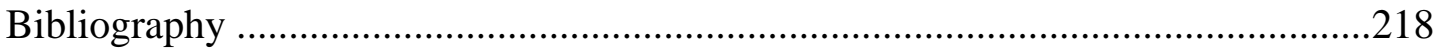




\section{LIST OF IMAGES}

Image

$\underline{\text { Page }}$

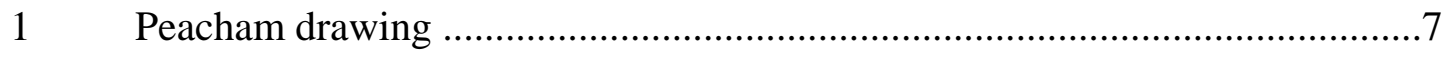

2 A Generalized Elizabethan Gentleman ....................................................... 14

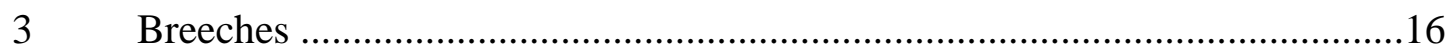

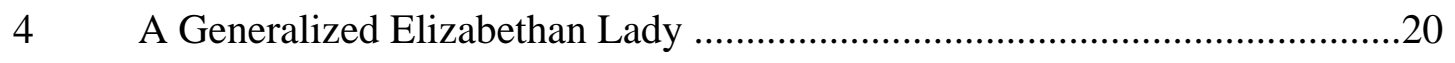

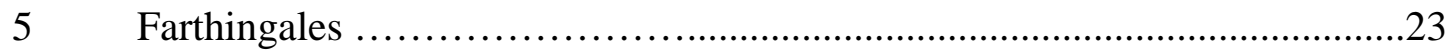

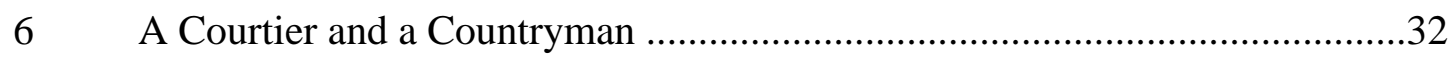

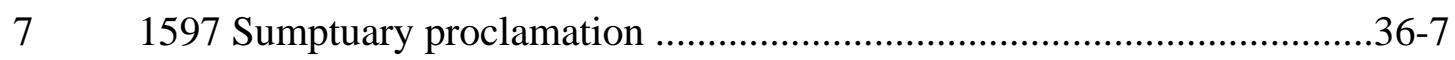

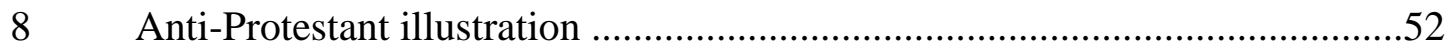

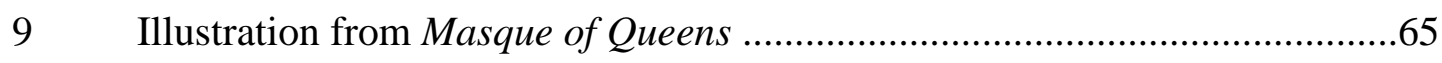

10 Drawing from Temple of Love ..............................................................66

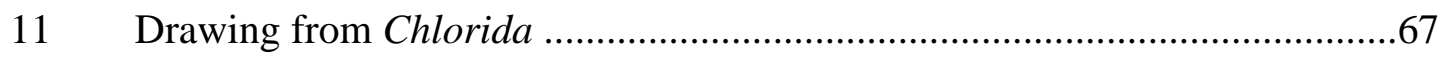

12 Title-page of A Game at Chess, Q1 .......................................................125

13 Title-page of Scott's Second Part of Vox Populi .......................................131

14 Title-page of A Game at Chess, Q3 .......................................................146

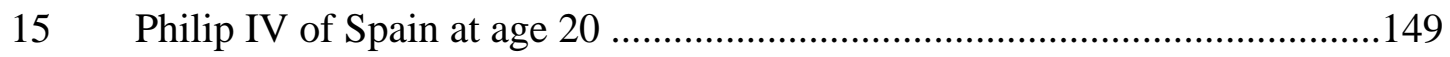

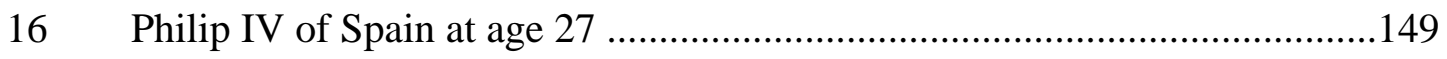

17 Lord Mayor's procession, c. 1614-15 …...............................................170 
18 The figure of Old Age in a 1635 print from the Lord Mayor's Show ..........174

19 The figure of Youth in a 1635 print from the Lord Mayor's Show ..............176

20 The figure of Manhood in a 1635 print from the Lord Mayor's Show ..........176

21 Fishing boat device in 1616 Lord Mayor's Show ....................................179

22 Lemon tree and Pelican device in 1616 Lord Mayor's Show .......................180 


\section{INTRODUCTION}

In 1566, the aldermen of London recognized that the sumptuary legislation passed during the reign of Philip and Mary and reasserted by Queen Elizabeth soon after ascending the throne in 1588 continued to be widely neglected in the city, despite their frequent efforts to enforce them. Consequently, they decided to put into effect a broad system of surveillance with strong penalties: the city companies were ordered to appoint four "sadde and discrete personages" to stand at each of the entrance gates to the city at seven in the morning,

Ther contynually to remayn and watche until XI of the clock, and from I of the clock in the afternoone of the same daye until VI of the clock at night, havinge a diligent eye duringe all the said tyme to all and everye such personne \& persons as they shall see there to enter into the Cyttye of London, or passe or repasse at or by the same gate usinge or wearinge annye greate and monstrous hosen, silk, velvet or weapons restreyned and prohibited. ${ }^{1}$

All who were found in violation of this act were to be taken before the magistrates at the Guildhall.

Queen Elizabeth’s disgruntled visit with the Lord Mayor in 1582 chronicles the failure of this rather extreme measure to keep the people of London from wearing 
apparel and fabrics outside the purview of their social class, for she charged him to see that her proclamations were enforced. Shortly after this discussion, the council in the Star Chamber personally admonished the Lord Mayor and the city aldermen for their inability to enforce the sumptuary laws. ${ }^{2}$ Throughout her reign, Queen Elizabeth and the London officials sought new and innovative ways to guarantee that the clothes an individual wore accurately indicated his or her place in England's highly stratified social order. And although the sumptuary laws were sometimes enforced, it is clear that they were more honored in the breach than the observance. ${ }^{3}$

The theatres proved to be the one place where the sumptuary laws regularly determined the apparel that people wore. There, it was essential that the clothes worn by an actor clearly represent his character's social standing. The sumptuary laws, as a consequence of the broad (if ineffectual) attempts to enforce them, constituted a widely understood visual code denoting the social class of characters appearing on the early modern stage. Indeed, mention of the sumptuary laws actually appears in an interlude from the period. In “Godly Queene Hester,” printed in 1561, the character Pride appears poorly arrayed, complaining that Aman has bought up all the good cloth, leaving none for others to buy. Pride further notes that if Aman catches anyone wearing fine clothes, he has them punished for violating the statute of apparel:

I tell you at a worde, Aman that newe lorde, Hathe bought vp all goood clothe, And hath as many gownes, as would serue ten townes Be ye neuer so lothe:

And any manne in the towne, doe by him a good gowne, 
He is verye wrothe.

And wyll hym strayte tell, the statute of apparell,

Shall teache hym good:

wherefore by thys daye, I dare not goe gaye ${ }^{4}$

The sumptuary laws may not have succeeded in controlling what was worn in English society, but they provided a stable referent for the theatres. Accordingly, the costumes that actors wore on stage served to visually establish their character's place in the body politic before an audience that was highly attuned to the specific fabrics and articles of apparel appropriate to particular social classes. But costumes conveyed far more information than just one's social class. They also presented a character's sex, occupation, nationality, and religion.

In order to explore the significance of theatrical apparel in early modern England, this dissertation will undertake a two-part study. First, it will examine a wide range of historical evidence in an attempt to piece together the visual codes that governed clothing in Shakespeare's England. Second, it will consider various theatrical venues (court masques, indoor and outdoor public theatres, Lord Mayor's Shows) to determine the specific manner in which the visual codes functioned in a range of performances at the time. Key to such a study is a reconsideration of the nature of the early modern English stage as a place where visual images as well as spoken words contributed significantly to the creation of meaning.

In late sixteenth- and early seventeenth-century England, costumes played a critical role in the establishment of a character's identity. The notion of an actor walking onto the stage of the public theatres as an empty cipher to be filled with the 
playwright's words needs to be amended to account for the fact that a great deal would have been known about his character the moment that his costume was seen. An actor could change from a man into a woman, an adult into a child, an Englishman into a Spaniard, a Protestant into a Catholic, or a king into a pauper by altering his apparel before returning to the stage. And an actor often had to. The casts of Elizabethan and Jacobean plays frequently had far more roles than there were actors to play them. ${ }^{5}$

By virtue of the costume worn, detailed aspects of a character's identity were likely well understood by the spectators before the actor even uttered his lines. For instance, in Shakespeare's Henry V 1.1, the religious vocation and rank of the two Bishops would have been clear to early modern audiences by virtue of the Catholic vestments the actors wore when they first appeared. But costumes functioned in much more complex ways as well. The apparel worn on stage had the potential to contradict the spoken lines. In these instances, an individual's identity was established by the joint presentation of competing discourses, one offered by the words spoken and the other presented visually in one’s apparel. Studies of cross-dressing have considered this aspect of costuming before: in Twelfth Night, the contrast between the words one speaks and the apparel one wears takes on comic importance when Viola agrees to wed the Duke while she still wears the clothes of a man. A very different contradiction between the words spoken and the costumes worn on stage can be seen in the 1609 Masque of Queens. There, the dialogue attributes the honor of the masque to the King. On the stage, however, Anne of Denmark and her fellow female masquers appeared as warrior Queens who triumphantly dominated the playing area. 
For the early modern audience in attendance, both the visual and the spoken elements of the masque contributed to the overall meaning produced in the production; in this instance, the meaning is not so simple as the dialogue of the masque suggests. Accordingly, a study of the costumes that were worn on early modern English stages becomes essential to understanding the experience of watching a performance at the time. Yet despite the significance of costumes and their codes, cultural historians have only begun to consider the role of clothing in the period's performances.

Moreover, the work that has been done relies far more heavily on written documents than on visually based information. For instance, using anti-theatrical tracts as the primary source of evidence, several new historical studies have considered how early modern audiences likely responded to seeing women's parts played by cross-dressed boys. These scholarly articles and books open up interesting new avenues of inquiry, but they have not considered how a boy might have looked in early modern women's clothes to determine the nature or extent of the artifice. ${ }^{6}$

Ann Rosalind Jones and Peter Stallybrass have separately and jointly pursued a cultural analysis of clothing in early modern England. ${ }^{7}$ As far reaching and important as their studies are, their examinations of performance almost entirely ignore the visual codes employed in production. They consider at length the circulation of apparel in theatre companies, but give little attention to how costumes appeared and were employed in performance or, just as importantly, how they were seen by contemporaries in the audience. Indeed, few examinations of early modern drama even consider the era's basic fashions. 
These fashions are important to studies of theatrical costumes because they were frequently one and the same. The clothes seen on the public playhouse stages were often those that were worn in England at the time, adhering to the same culturally specific visual codes. Thus, in Much Ado About Nothing, Benedict laments Claudio’s fall from warrior to lover by saying: "I have known when he would have walk'd ten mile afoot to see a good armor, and now will he lie ten nights awake carving the fashion of a new doublet” (II.3.15-8). ${ }^{8}$ Evidence from the plays suggests that even in dramas set in far away locales and in the distant past, actors often wore contemporary English clothing. For instance, in Julius Caesar, Casca says that when Caesar perceived that the people were glad he refused the crown, "he pluck'd me ope his doublet, and offer'd them his throat to cut” (I.ii.263-6). Despite being set in ancient Rome, the language of costume is markedly that of early modern England. ${ }^{9}$ Additionally, the Peacham drawing, portraying characters from the story of Titus Andronicus, ${ }^{10}$ presents Roman costumes alongside apparel that was common in English society. 


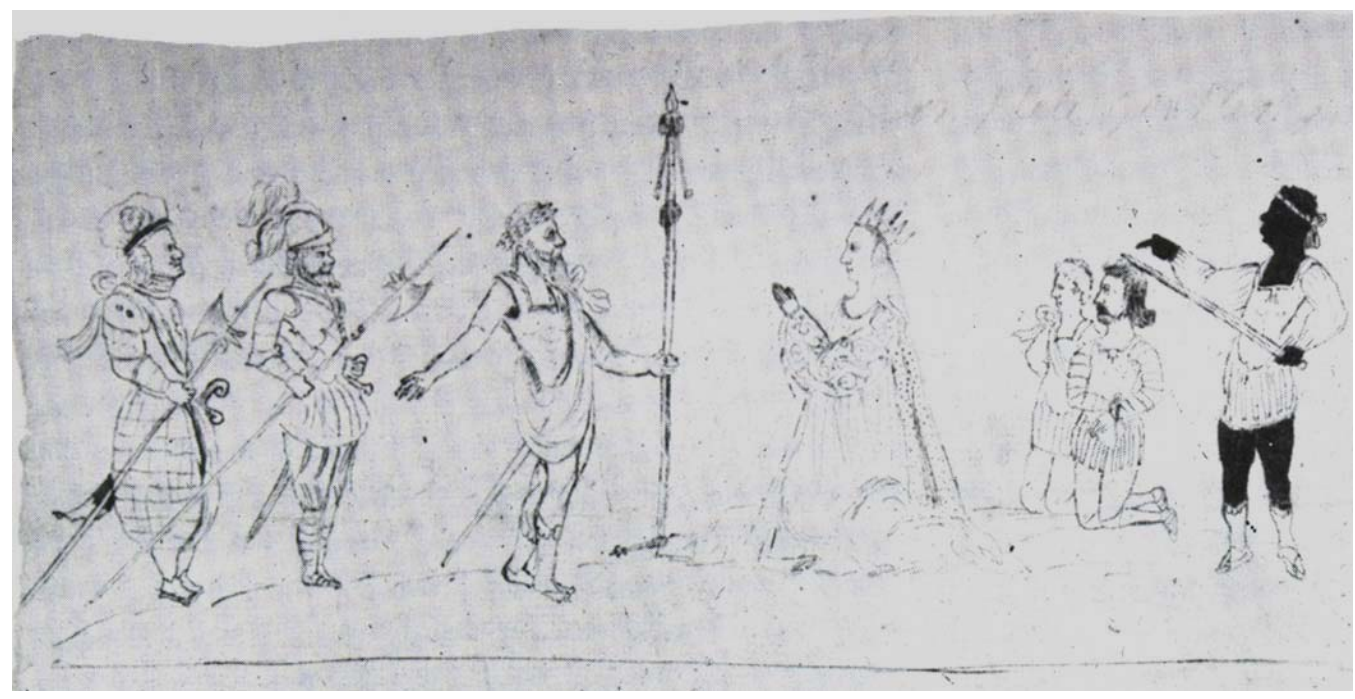

Image 1. Peacham drawing ${ }^{11}$

In order to begin examining theatrical apparel, this dissertation starts by exploring the basic fashions of the period. Chapter one lists the basic articles of clothing worn in England in the late sixteenth- and early seventeenth-centuries and the visual codes according to which an individual would have been understood by the apparel he or she wore. Accordingly the chapter begins with a catalog of the clothes that were commonly worn by men and women in the period. What was the difference between trunk hose and galligaskins? Ruffs and bands? Spanish farthingales and French farthingales? Considering how actors actually appeared on stage is crucial to understanding plays that frequently offer comments on the clothes of the characters (e.g., articles, colors, and fabrics). Next, the chapter investigates the visual codes whereby one’s apparel asserted one’s sex, social class, occupation, nationality, and religion.

The second chapter considers the manner in which costumes were employed in the Stuart masques. Of course, several scholars, including Stephen Orgel and Roy 
Strong, have investigated these elite entertainments provided for the Stuart monarchs. Consequently, this examination of costuming practices in Shakespeare's England derives in part from the work that other scholars have undertaken. Yet I seek to provide a richer understanding of the complex manner in which costumes signified in the Jacobean and Caroline court. Responding to the highly political considerations of recent masque scholarship, I note that the visual presentation of the costumed masquers contributed meaningfully to the performance and at times offered a challenge to the arguments asserted by the spoken dialogue.

Chapter three examines the practices of the professional theatre companies to determine how apparel contributed significantly to the establishment of meaning in public theatres. To begin, costumes represented a theatre company's single greatest financial investment and were crucial to a troupe's survival and success. An analysis of the plays that dominated the stage between the 1580s and 1620s shows the manner in which costumes served not merely to present aspects of a character, but also to forward the action of the drama. This chapter also considers the costuming practices that derive from the interlude tradition and which inform the productions of the professional companies. Finally, I examine the practice of disguising in order to show how it contributed to the stability of the visual codes employed in performances at the time.

Chapter four picks up where the previous chapter leaves off and undertakes an in-depth analysis of a single play and its production. The 1624 run of Thomas Middleton's A Game at Chesse elicited a considerable amount of contemporary commentary, more than any other play from the period. As a result, a written record 
exists detailing aspects of production that might otherwise be lost. This record provides a rich picture of how Middleton's performance actually appeared at the time. Armed with this information and other historical evidence, this chapter seeks to establish the manner in which visually based information figured critically in the play’s politics and production.

Chapter five considers how costumes functioned in the annual Lord Mayor's Day events. Typically, scholars analyzing the Lord Mayor's Day focus their attention on the pageant performances that were written by some of the most popular playwrights at the time. This study takes a different approach, opting instead to focus attention primarily on the carefully orchestrated progress of the Lord Mayor and his entourage through London. Additionally, it opens up for analysis the events of the day before the Lord Mayor's Day, arguing that the ceremony surrounding the swearing in of the new Lord Mayor at town hall deserves as much attention as the more commonly studied events surrounding the Lord Mayor's oath of fealty to the King. The costumes worn for both days identified the wearers within the systems of power that governed London and reified its particular relationship to the crown.

In pursuit of its study, this dissertation considers royal proclamations, paintings, woodcuts, plays, historical accounts, sermons, and legal documents. Ultimately, "Costuming the Shakespearean Stage” articulates the crucial manner in which costumes and apparel informed the substance, the staging, and the reception of theatrical and cultural performances in early modern England. 


\section{CHAPTER 1}

\section{VISUAL CODES OF REPRESENTATION}

In the early modern English protocapitalist culture, clothing possessed the ability to define a person's identity and locate his or her position within multiple, overlapping cultural categories. One’s sex, rank, occupation, nationality, and religion could be established by the clothes one wore, which produced an individual as a member and constituent of the body politic. The information that one's apparel visually presented in English society profoundly influenced the costuming practices employed on the period's stages.

For instance it is often noted that boys played the role of women in Shakespearean drama, but how did they appear on stage when they wore women's clothes? And how did they appear to contemporaries who attended the theatre? A survey of late sixteenth- and early seventeenth-century clothing reveals that the apparel most frequently worn by women at the time was multi-layered and often shaped. It thus served to determine one's physical form as much as it reflected one's natural build. Therefore, it is very likely that the boys appearing on stage would have provided a very thorough illusion of the female characters they portrayed. 
One’s social class could similarly be depicted accurately on stage as a consequence of the sumptuary laws that established a widely understood set of guidelines determining what clothes were appropriate to particular levels in society. By donning a rich set of apparel in one scene and clothes made of lesser fabric in another, an actor could very easily play two roles that would be understood on sight to represent characters of different classes.

For those who were not gentlemen or gentlewomen, one’s occupation dictated the clothes typically worn in early modern England. For many workers, particular apparel and accoutrements were required for one's job, and were therefore easily understood when presented on stage. For instance, an actor performing the role of a shoemaker would not need to mention his occupation since the black leather apron and “Saint Hughes bones” (shoemaker’s tools) would make his character’s occupation obvious.

Actors often played the parts of foreign characters, and their apparel helped to establish the individual's nationality. This is not to suggest that the actors necessarily wore costumes that reflected the subtle fashion trends of the countries they represented. Rather, the clothes the actors wore presented the visual signs denoting one’s nationality before the English audience. In this manner, a study of nationality on the Shakespearean stage is always a study of English visual semiotics.

One’s religion could also be presented visually on stage. Despite Queen Elizabeth’s 16 May 1559 decree against the inclusion of religious subject matter in plays and interludes, the public theatres often staged priests, bishops, cardinals, 
popes, friars, nuns, ministers, puritans, and Jews. Each of these roles was easily identifiable by the particular apparel associated with it.

The extraordinary range of roles that would have been recognized by the early modern audience becomes apparent when we note the characters that inhabit dumb shows in the period. G. K. Hunter found Popes, Cardinals, Bishops, monks, Nuns, and Friars to be among the most common characters. However, he also found other, less obvious characters: “Midwife,” "Doctor of Physic,” "Nurse,” “Ambassadors,” “Councillors and Pensioners,” "Roman Senators," "Senators,” "Mufti,” and “Turks,” Master of a ship,” “Herald,” “Maiden of Honour,” "Serjeant, with a mace under his girdle,” “[a devil] . . . in black robes like a pronotary,” "Nymphs attired accordingly,” and “an Irishman.” Hunter notes that all of these seem to appear in contexts where

recognition of the "character” is essential to understanding the action. ${ }^{1}$ Consequently, we must understand the characters to have been highly recognizable according to the costumes they wore.

\section{$\underline{\text { Basic Fashions }}$}

Throughout the period from 1567 to 1642, there were a number of basic components of clothing for men and women that altered in style but remained staple items. The fundamental garments of the Elizabethan and Jacobean period were the same ones that had maintained for over a hundred years and would remain so until the latter half of the seventeenth century. ${ }^{2}$ The following section will attempt to detail the articles of apparel that were most commonly worn in the era. The list of garments that follows makes no attempt at comprehensiveness. There are innumerable additional 
articles of clothing and fashion trends that could be noted and described, and such an examination would constitute a separate study. ${ }^{3}$ For my purposes, it is sufficient to establish a starting point from which we can consider the visually based semiotic systems according to which early modern audiences understood the apparel worn on the English stages.

For men, the most commonly worn articles of apparel include the shirt, doublet, breeches, nether hose, jerkin, cape, robe or gown, ruff or band, hat, and footwear; for women, the chemise, dress or kirtle, farthingale, gown, ruff or band, headdress, and footwear. To clarify how this clothing actually appeared, image 2 presents a generalized Elizabethan gentleman. The danger in including such a picture is that it suggests that the fine clothes depicted represent the norm at the time and thus occludes the differences that clearly marked people of different classes. It must be stressed that the picture is most useful for helping readers to understand what the particular articles of apparel were. In much the same way that a wealthy man and a poor man today might both wear shirts, pants, and sport jackets yet look radically different, so was it possible for gentlemen and laborers in early modern England to wear the same basic articles of apparel yet present very different images. 


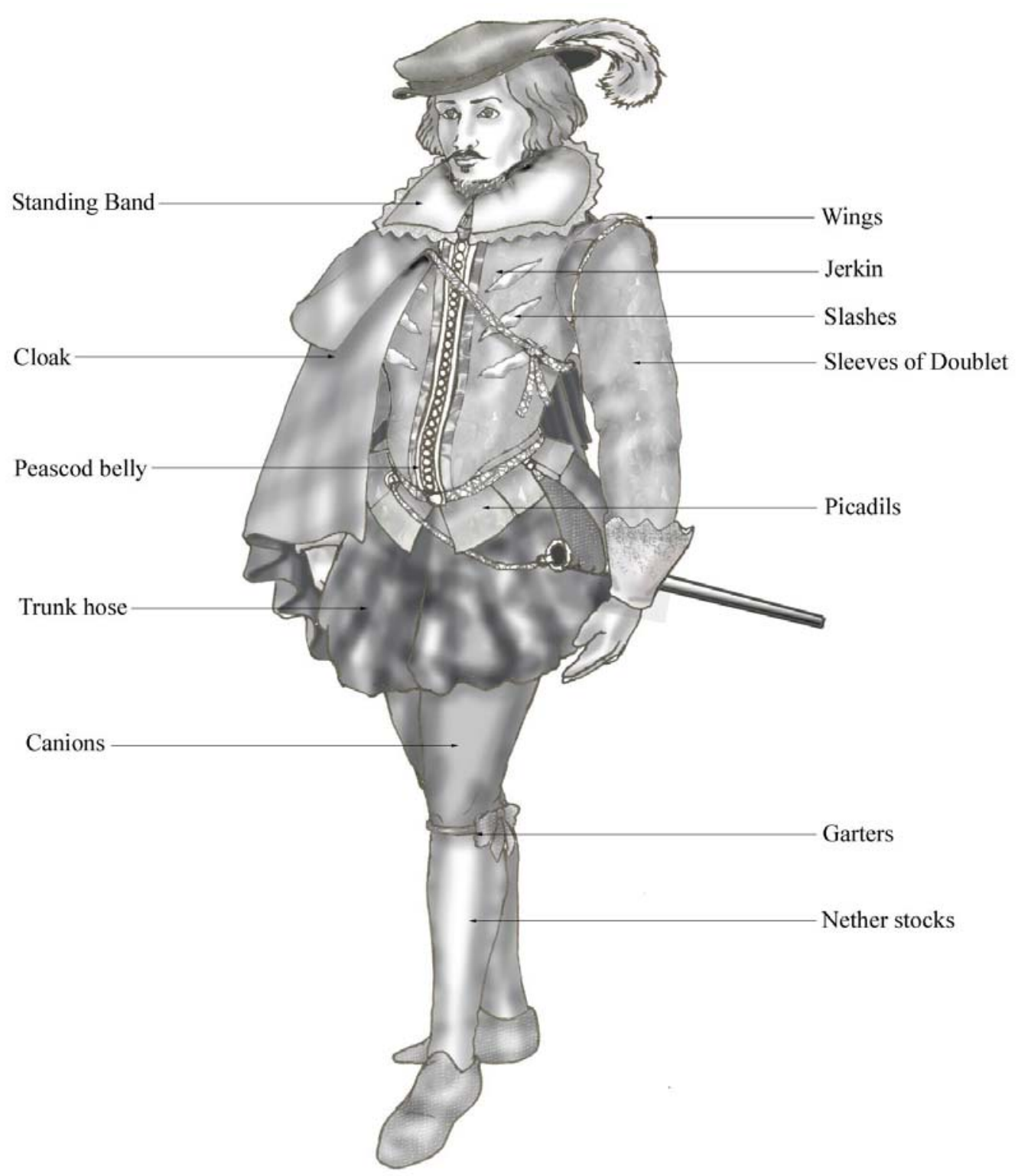

Image 2. A Generalized Elizabethan Gentleman ${ }^{4}$

The man’s shirt was typically made of white linen and served primarily as an undergarment until roughly 1625, after which time the fashion changed and it was more commonly seen through the doublet. It was usually cut full and gathered into a round or square neckline, having long, raglan sleeves. Even before 1625, the fabric of the shirt might be seen through the doublet if there were slashings or panes, cuts 
made in the outer garment that allowed the undergarment to be seen. Among the wealthy, it was common to wear shirts that were embellished with drawn-work and embroidery.

The doublet was a thick, quilted upper garment of velvet, silk, satin, leather, or other material, which extended from the neck to below the waist and was buttoned up the center. Until 1580, the doublet was snug against the body, at which time the practice of having a peascod belly, a swelling lower abdomen, became popular. This fashion lasted until roughly 1610 when form-fitting doublets once again became the norm. ${ }^{5}$ The sleeves of the doublet were sometimes detachable and would be connected by points, laces or ties which ended in small metal tips. Points were used to connect separate pieces of clothing at the time and required that a person receive assistance from others while dressing him or herself.

Breeches go by many names in the early modern period including: trunk hose, canions, Venetians, galligaskins, and slops. Most generally, they were considered the upper part of the hose or stocks and served the purpose of covering the top part of the leg. The various terms for this article of clothing are used interchangeably in the drama of the period but distinguishable features for each can be identified. Trunk hose generally were well rounded and reached from the waist, where they were connected to the doublet by points, to the middle of the thigh, where they were connected to the nether stocks, which were much like stockings. Canions were close fitting extensions that were sometimes used to connect the trunk hose to the nether stocks; they typically reached from mid-thigh to the knee. Panes were often worn over the trunk hose and consisted of strips of fabric that reached from the waist to the bottom of the 
breeches. Venetians were breeches much like trunk hose but reached down below the knee. Galligaskins sloped gradually from a narrow waist to fullness at mid-thigh. Slops referred to wide breeches that were open at the knees. Breeches could follow the shape of the leg or be heavily padded with bombast, a stuffing made of almost any available fabric. The various terms defined here give some idea of the various fashions at the time, but we should be careful about assuming that we know how an actor's breeches looked simply because the lines of a play say that he is wearing a particular style since the terms were sometimes used interchangeably, even indiscriminately.

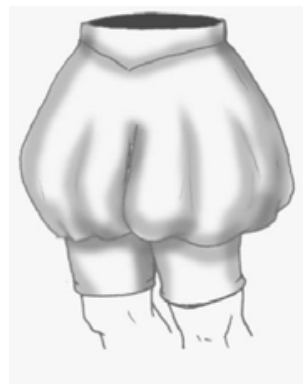

Trunk hose w/canions

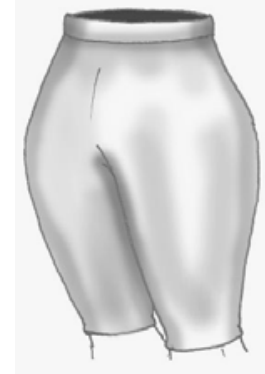

Venetians

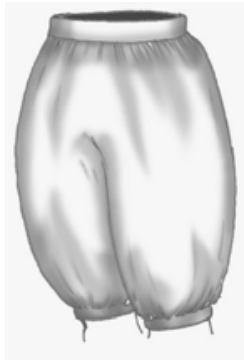

Galligaskins

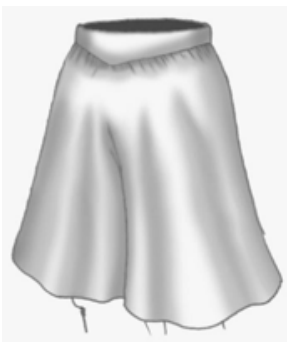

Slops

Image 3. Breeches. ${ }^{6}$

The nether stocks were worn like tights and showed off the leg of the wearer. They were held up with garters, lengths of cloth or silk that were tied around the leg, either above or below the knee. The brief fashion for cross-gartering which Malvolio adopts in Twelfth Night consisted of wearing either garters both above the knee and below the knee or a single band rolled back on itself so that it would serve as a garter above the knee and below the knee and be crossed behind the leg. 
The jerkin was a jacket-like garment that was worn over the doublet. In many of the paintings from the era, the jerkin is made of the same material and follows the same pattern as the doublet. As a result, it is sometimes difficult to tell if a jerkin is being worn. Jerkins frequently had short puffed sleeves or no sleeves. Most paintings of the era show the jerkin drawn in to the waist, but sometimes it had a peplum or basque, i.e., a skirted extension that covered part or all of the breeches.

English capes or cloaks were regularly half-length, extending from the shoulder to the middle of the body and are shown in most paintings to be slung over the left shoulder only. They often had fake sleeves attached. Capes or cloaks were apparently considered indispensable traveling gear for the gentility, for mention is made of men who are compared to tapsters for appearing without their cloaks. ${ }^{7}$ Later in the sixteenth and into the seventeenth century, longer cloaks came into fashion in England.

Robes or gowns in early modern England reached to the ground and typically had large funnel-shaped or hanging sleeves. Before the middle of the sixteenth century, short gowns that reached to the hips were common and many depictions of Henry VIII show him thus attired. Pictorial evidence suggests that after 1550, the practice of wearing short gowns was replaced by the fashion of wearing a cloak. Full length gowns were the common attire of the professions: lawyer, physician, clergy. The were also commonly worn by older men and by members of the middle class on ceremonious occasions. ${ }^{8}$

The ruff was a popular fashion for most of the Elizabethan and Jacobean period. It appears merely as a small cambric, holland, lawn, or lace frill at the neck in 
illustrations prior to 1570. After that time, particularly as a consequence of the introduction of starch into England in 1564, the ruff expanded greatly. The starch held the ruff in a particular shape and kept it from bending. ${ }^{9}$ In Ben Jonson's The Alchemist (1610), Subtle describes a man wearing a large ruff: "He looks in that deep ruff like a head in a platter" (4.1.24). ${ }^{10}$ James Laver notes that the ruff, growing sometimes to a quarter of a yard in radius, was an article of clothing worn exclusively by gentlemen since it emphasized the fact that its wearer did not need to work. ${ }^{11}$ The enormous ruffs that became more common towards the end of Elizabeth's reign may lead one to wonder how the wearer managed to eat. And yet, this article of clothing is so common in the portraits of nobles and gentry in the era that we must understand it to be common apparel of widely accepted taste. Instead of wearing a ruff (or even in addition to it), Englishmen sometimes wore collars, called bands. One could wear a falling band which folded down from the neck or a standing band that would stand out from the neck with the aid of starch. Matching ruffs or bands are often seen on sleeves in paintings from the period. By the 1630s, the band had largely replaced the ruff in English clothing.

Two types of hats were most popular in the Elizabethan and Jacobean period. The first, a bonnet, is low-crowned, made of soft material, and often decorated with a feather. The second is high-crowned, made of a stiff material, and built in sugar-loaf form. ${ }^{12}$ Flat caps were also widely worn, primarily by citizens and apprentices. They were round, had a narrow brim, and were flat across the top. In 2 The Honest Whore, Dekker explains how flat caps were understood at the time by stating that "Flat caps as proper are to Citty Gownes," as to "Kings their Crownes” (1.3.69-71). ${ }^{13}$ In early 
modern England, hats were worn indoors as well as out. The doffing of one's hat was a sign of respect, and a courtier would typically only take off his hat and keep it in his hand in the presence of the king. Andrew Gurr has noted that this practice of demonstrating fealty with one's hat provides an explanation for why, in Hamlet, Osric keeps his hat off in the presence of Hamlet. ${ }^{14}$

Men's footwear in early modern England consisted of shoes and boots. Pictorial evidence shows that the shoes were square-toed in shape and did not begin to have heels until the end of the sixteenth century. They were made of a variety of fabrics, from silk and velvet to leather and plain cloth, and had soles of either leather or cork. Decorations included slashing, rosettes, or decorative stones. Boots were primarily used for riding until the last quarter of the sixteenth century when they began to receive more general use. Made of soft leather, they were of varying size and the tops are often shown turned down. 


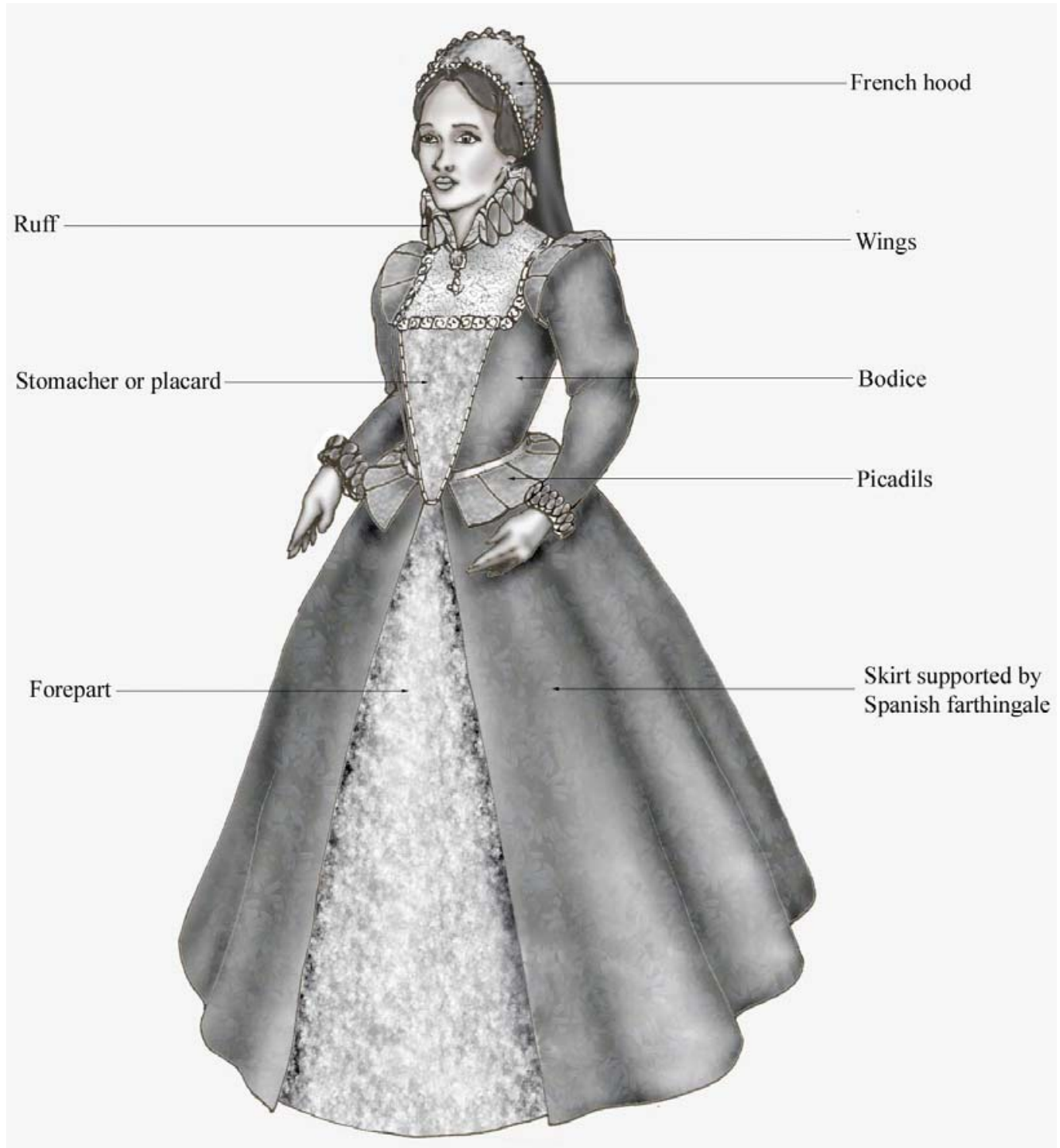

Image 4. A Generalized Elizabethan Lady. ${ }^{15}$

The undermost garment worn by Lady was the chemise, the equivalent of a man's shirt. However, the chemise often reached all the way down to the ankle. Typically made of white linen, it could have a rounded or square neckline, offering either covering for the neck or the possibility of décolletage. Although it served 
primarily as an undergarment, the chemise could sometimes be seen when it served to cover the neckline.

Most early modern Englishwomen’s dresses or kirtles consisted of two parts, the bodice and the skirt, which were typically sewn together. The bodice was often quite rigid and tapered to a sharp point at or below the waistline. To maintain this shape, it was sometimes bolstered by busks or stays made of wood or whalebone, or even by iron bodies that were either a part of the garment or worn underneath it. Sometimes a V-shaped opening appeared in the front of the bodice which allowed a different fabric underneath, a stomacher or placard, to be seen. The stomacher was a separate article of clothing from the bodice and was usually made of very stiff material. The sleeves were not a part of the bodice but were connected to it by points. They were close-fitting cylinders in the 1560s and grew to be puffed, slashed, leg-ofmutton sleeves in the 1580s. ${ }^{16}$ By 1600 , the sleeves had diminished in size but remained larger than the woman's arms. By the 1620s, the sleeves were, once again, close-fitting. Where the sleeves connected to the bodice, there were often decorative wings which hid the connecting links.

The skirt, covering the lower half of a woman and constituting the second part of the kirtle, was often bolstered by a farthingale and/or by petticoats, additional underskirts. Farthingales, stiff accessories consisting of hoops of padding, rushes, wood, wire, or whalebone which held out a woman's skirt, came in three varieties. The first ones worn in England were Spanish farthingales, which came into fashion and were common apparel before the first public theatres opened. Spanish farthingales were built like upside-down cones or bells; they were circular, being 
small at the waist and growing gradually to a wide circumference at the feet. With this farthingale, a woman's skirt would sometimes have an opening in the front in the shape of an upside-down $\mathrm{V}$ through which the fabric of a petticoat might be seen or a separate piece of fabric, a forepart, would be visible. The forepart was often made of cheap material around the back and of expensive fabric with highly wrought embroidery in that section where it would be seen through the skirt. The French farthingale came to dominate English fashion by the turn of the seventeenth century. It consisted of a padded roll that was worn around the waist, under the skirt, and resembled a life preserver. It was sometimes called a bum roll. The third type of farthingale was the drum farthingale which consisted of a hoop worn at the waist from which the skirt fell straight to the ground. This farthingale was commonly seen at court roughly from the 1560 s to $1620 .{ }^{17}$ A circle of soft pleats was often worn over the drum farthingale to cover the hoop and soften the perpendicular bend of the dress before it reached to the ground. Despite the widespread appeal of the farthingale, it was not worn by all women, even during its greatest popularity. By the 1620s, farthingales decreased in popularity in England, being replaced by full-gathered skirts which hung in soft folds. 


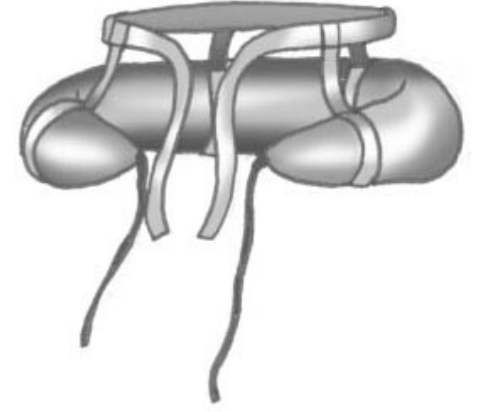

Bum Roll

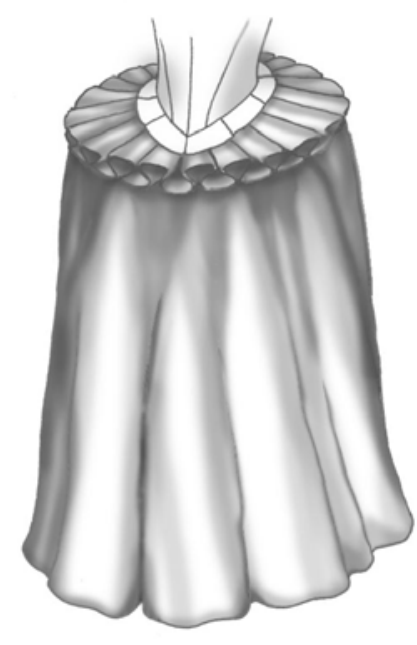

Drum Farthingale

Image 5. Farthingales. ${ }^{18}$

The woman's gown was usually a loose piece of apparel that was open at the front and reached all the way down to the feet. Gowns were worn on top of all other garments except perhaps a cloak, although the gown would sometimes serve instead of a cloak to keep the wearer warm. Gowns might or might not have sleeves. A woman might also wear a night-gown which differs from the usual gown in being less elaborate, warmer, and less likely to be confined at the waist. ${ }^{19}$ It is important to note that night-gowns at this time were not limited to the bedroom, but also would be worn outside as a common piece of apparel.

Ruffs and bands were articles of clothing fashionable among women and men in early modern England, though women had more styles of neckwear available to them. For women, the ruff could be closed, presenting an unbroken circle around the neck, or it could be open at the front. The latter style is better suited to décolletage and was more frequently worn by unmarried women along with low cut bodices. ${ }^{20}$ 
The edges of the open ruff would rise from the sides of the décolletage and spread out like a fan behind the woman's head. With particularly large ruffs, women sometimes wore a frame, called a supportasse, to hold the garment in place and push up the rear. By 1610, the ruff was replaced in popularity by the standing band, a collar that reached straight out from the neck. Although ruffs became less popular in the seventeenth century, they were still widely worn until the 1630s when the fashion turned towards falling bands, collars that folded down, and the ruff largely disappeared from women's apparel in England. Women's falling bands were similar to men's, consisting of a wide collar at the neck which was usually starched, open at the front, and folded down against the bodice.

Women could choose among a number of overlapping fashionable choices of headdresses in early modern England. The articles most commonly seen in portraits of the era are the coif and the French hood. The coif was made of embroidered linen, lace, or other material and covered the back of the head. The French hood similarly covered the back of the head but was made of stiffened material, hanging down below the neckline in a veil on either side of the face. The hanging veil was sometimes drawn up and pinned to the crown of the French hood, or wired out to either side in a horn-shaped figure. ${ }^{21}$ In the 1590s, fashionable women sometimes wore high hats similar to those worn by men at the time. This fashion did not last long, and afterwards women were frequently depicted wearing no headdress at all.

Women's hair styles, like clothing, changed over time. Studying portraits from the era, Graham Reynolds states: 
With the advance of the 1570s and 1580s it was curled and wired out to either side in a horn-shaped figure, the width increasing step by step with the ruffs and puffed sleeves. After 1590 this horn-shaped coiffure gives way to one which rises vertically from the forehead, and by 1600 curls are superseded by hair brushed flat and shaped high over a pad. At this time and later, some ladies, perhaps mainly unmarried ones, adopted the delightfully romantic style of long hair falling loosely over their shoulders. The hair is bedecked with jewels, often wired into delicate cresting. ${ }^{22}$

It is important to note that evidence from the period is limited to what can be seen in portraits. Naturally, this influences the conclusions we can draw about the hair styles that were popular at the time.

Women's shoes at the time were nearly identical to those worn by men. In portraits of the era, they are frequently hidden beneath the skirt or peek out from under it. They were often decorated with ribbon ties, and after the 1590s, had roses made of ribbon or lengths of lace.

\section{Early modern costume semiotics:}

Sex

Perhaps the most important information, and likely the first, communicated to an early modern English audience by an actor's costume was the character's sex. With all male casts, the sex of the character on stage would be overwhelmingly

determined by an actor's clothing. Barring three exceptions noted by Stephen Orgel, ${ }^{23}$ 
the female roles in Elizabethan and Jacobean drama were played by boys dressed in women's clothes. We can begin to understand how the early modern audience distinguished among the characters simply by noting the differences between the clothes that men and women wore in the era. The extent of the artifice, however, needs to be considered.

When we take into account the ensemble that would have been worn by a boy playing a woman on the early modern English stages, it seems likely that the illusion was very convincing. First, we can note the layers of clothes that a boy would have worn. At the very minimum, he would wear a chemise and a kirtle, or at night a chemise and a night-gown, two layers that covered the actor from neck to foot and could be altered or enhanced to provide nearly any shape desired for the wearer. Additionally, the boy would almost invariably wear a wig, simulating the long hair that was expected of women throughout the period. The expectation that men have short hair and women wear theirs long can be noted in numerous places. In The Two Gentlemen of Verona, when Julia plans to dress the part of a page, Lucetta explains "Why then your ladyship must cut her hair.” King James was offended by women who dressed as men and wore their hair short, and sought exhorted the London clergy "to inveigh vehemently and bitterly in their sermons against the insolency of our women, and their wearing of broad-brimmed hats, pointed doublets, their hair cut short or shorn, and some of them stillettos or poniards ... adding withall that if pulpit admonitions will not reform them he would proceed by another course. ${ }^{, 24}$ An even more determined argument against the cutting of women's hair was offered by William Prynne in The Unlovelinesse of Lovelockes, published in 1628: 
sundry of our mannish, Impudent, and inconstant Female sexe, are Hermaphradited, and transformed into men; not only in their immodest, shamelesse, and audacious carriage, (which is now the very manners and Courtship of the times;) but even in the unnaturall Tonsure, and Odious, if not Whorish Cutting, and (a) Crisping of their Haire, their Naturall vaile, their Feminine glory, and the very badge, and Character of their subiection both to God, and Man.,25

According the Prynne, the cutting and crisping of a woman's hair defies God, shows her to be a whore, and marks her as a man. Although Prynne typically presents extreme opinions held in early modern England, here he provides simply the most zealous argument for an opinion that seemed to be widely held. No doubt in practice men often wore long hair and women no doubt sometimes cut their hair short. And yet, audience members would normally have expected hair length to be sexually determined. Dressed in just a chemise and a kirtle or a nightgown, and wearing a wig, the cross-dressed boy could very much look the part of a woman.

Yet, in light of the number of Countesses, Duchesses, and other women of wealth and significance that populate the dramatis personae of early modern English plays, the boy playing the woman's part was likely dressed in numerous, lavish layers for a nearly complete and visually appealing illusion. What might a boy look like on the stage in the role of a Lady? On the innermost layer, he would wear a chemise. Over that, on the top half of his body, he might have a bodice enforced with wooden stays that maintained a particular feminine shape regardless of the body underneath. Next, the female shape would be accentuated and made more luxurious by a firm 
stomacher that reached down to a point below the waist. This narrowing of the top of the kirtle would then be inverted on the bottom by the skirt which extended down and out according to the line of the farthingale which would completely hide the shape of the lower half of the actor's body. Even towards the end of the period we are examining, when the farthingale grew out of fashion, women wore several petticoats which would create nearly the same effect. On top of the kirtle, a gown would cover the shoulders and reach to the ground, providing additional warmth and further splendor. Around the actor's neck, a ruff of two or three layers would cover the region between the dress and the chin. A French hood would cover the back of the hair and drape down the sides, allowing perhaps a few locks of hair from a wig to slip out the sides. If the female character was from a city comedy and she was walking about outside, it would not be exceptional for her to don a mask which would cover most of her face. Thus, very little of the boy underneath the clothes would be visible. Assuming that the boy was not too young or at least not of diminutive size, the costume would believably construct the actor's female identity according to the visual codes of the time. ${ }^{26}$

And yet, it is important to note that an actor's male identity needed to be constructed on stage as well. This is most apparent in the boy companies in which all of the parts, both those of men and women, were played by young actors. Here we find a somewhat similar situation to that in which boys cross-dressed in order to personate female identity. The multiple layers of clothing worn by men at the time could conceivably hide the youthfulness of the wearer beneath. In the late sixteenth century, this could have been accomplished by wearing firm doublets that did not so 
much conform to the shape of the wearer as determine it. A peascod belly would further hide the body. In the seventeenth century, when doublets were often far less rigid, a boy would still have a shirt on underneath, perhaps a jerkin on top, and a cape or gown which further covered the body.

Of course, smaller members of a cast of boys from ten to fifteen years of age might have difficulty effectively impersonating adult men. In those situations, the boy would need to wear the accoutrements that signified masculinity, even if they did not succeed in emulating it. ${ }^{27}$ Will Fisher argues that in early modern England, "sex was materialized through an array of features and prosthetic parts.” Among these he includes the beard, the genitals, clothing, the hair, the tongue, and weapons such as swords and daggers. ${ }^{28}$ For the purposes of the public stages, the actor's genitals were always covered and did not bear on the character's sex. The codpiece, which is frequently worn in "historically accurate" productions of Shakespeare, was popular until the middle of the sixteenth century but was out of fashion by the time the public theatres opened in London. ${ }^{29}$ The other signs of masculinity, however, could easily be employed to establish a character's sex. The beard was a highly visible and important aspect of one's masculinity in the late sixteenth and seventeenth centuries. Noting that virtually all of the men depicted in portraits from 1540 until a century later have beards, Fisher provides a potent argument for the likelihood that beards were a major part of the means by which masculinity was visually asserted and acknowledged in early modern England. He goes on to note that prosthetic beards were certainly employed at university productions and provides convincing evidence from the plays 
performed by children's companies to suggest that they, too, made frequent use of fake facial hair. ${ }^{30}$

A survey of the extant pictures of English actors from the early modern period reveals that they all exhibit facial hair. Furthermore, the images suggest that the beard was an expected symbol of a character's masculinity on the stage. The prevalence of facial hair on men also provides a very practical explanation for why the plays of the period frequently employed the strategy of having female characters cross-dress as men in order to further the action of the play but primarily had men dress as woman merely for slap-stick, comic effect. If a woman needed to dress a man's part in early modern England, she could don a prosthetic beard and wear his apparel, which can effectively hide an individual's physical shape and provide an effective illusion. A man, on the other hand, could not believably accomplish the reverse. In a woman's ensemble, the one part of the body that is revealed when fully dressed, the lower half of the face, is precisely that which would assert the character's masculinity.

A cross-dressed man might try to hide his beard by wearing a large square piece of material over his chin called a muffler, or a chinclout, such as women sometimes wore outside, but facial hair would threaten to peek out the sides and make the stratagem comical. Seeking to hide Falstaff, Mrs. Page says “There is no woman’s gown big enough for him; otherwise he might put on a hat, a muffler, and a kerchief, and so escape” (4.2.69-72). The image of Falstaff once he has been fitted in an enormous gown and has his beard covered, is not likely one of believable femininity, but of comical absurdity made manifest by the concurrent visual presentation of elements that denote both masculinity and femininity. ${ }^{31}$ 
The problem of hiding a beard would not exist for the actors in boy companies who would have to use costumes and accoutrements to assume the role of either a man or a woman. Indeed, Fisher argues that a boy actor in early modern England would be "in drag" as much when he was dressed as a man as he would be dressed as

a woman. ${ }^{32}$ Clean of face and not yet sexually potent, the boy had neither the visual signs nor the sexual maturity that defined a man. Furthermore, it is likely that many of the boy actors' voices remained higher pitched than those of adult men. In such a situation, the importance of one's theatrical apparel becomes paramount. On the early modern English stage, costume, here meant to include such accoutrements as prosthetic beards, wigs, and swords, was responsible for determining and asserting the sex of the characters.

\section{Social Class}

Equally important to costume's ability to determine an actor's sex was its ability to establish the social class and occupation of the wearer. The society of early modern England was highly stratified, and clothing provided the key means by which individuals visually established their place in the hierarchy. For a sense of how one's clothes would quickly differentiate those of different class, here is an illustration from Robert Greene’s A quip for an vpstart courtier depicting a courtier and a countryman. Note that both wear the same basic articles of apparel (hat, jerkin, doublet, breeches, netherhose, boots) yet look strikingly different. 


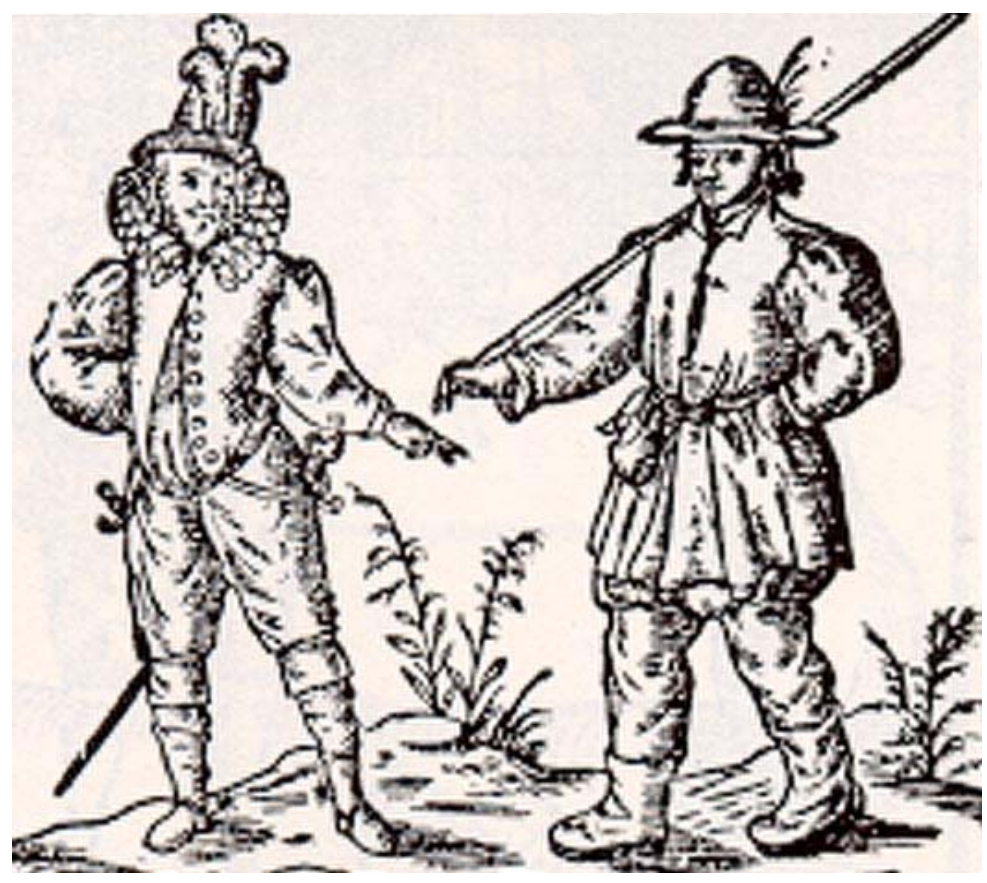

Image 6. A Courtier and a Countryman. ${ }^{33}$

Andrew Gurr explains that writers from the period saw their society as divided into four classes: nobles and gentlemen, citizens and burgesses, yeomen (rural smallholders), and artisans and laborers. ${ }^{34}$ However, early modern English society was far more complexly divided than that, with each of the four groups sub-dividing into smaller hierarchies. Accordingly, it was widely believed in England that one's clothing should accurately identify more than just the wearer's general social class. Extensive sumptuary legislation that lasted until 1604 worked to guarantee that the clothes one wore accurately depicted the wearer's specific social standing and occupation.

And yet, it is well known that the sumptuary laws were often defied. The frequent royal proclamations passed during Queen Elizabeth’s reign (1559, 1562, 1566, 1571, 1574, 1580, 1588, and 1597) sought to ensure that one’s clothes 
accurately depicted one's social station. And yet, they justify their own passing by "consydering to what extremityes a great nombre of her subjects are growne by excesse in apparel, both contrary to the lawes of the realm and to the disorder and confusion of the degrees of all states" (issued in 1566). ${ }^{35}$ Similarly, the attacks made against excess of apparel from the pulpit and in puritan tracts only make sense if the laws and expectations for appropriate dress were being flouted. These attacks were common, and remained so even after the sumptuary laws were repealed in England in 1604. Phillip Stubbes, although a radical writer at the time, employs language very similar to that of Queen Elizabeth's proclamation when he inveighs against excess of apparel in 1583 in his Anatomie of Abuses:

It is verie hard to knowe who is noble, who is worshipfull, who is a gentleman, who is not: for you shall have those which are neither of the nobylitie, gentilitie, nor yeomanry; no, nor yet anie Magistrat, or Officer in the common welth, go daylie in silkes, velvets, satens, damasks, taffeties, and such like, notwithstanding that they be both base by byrthe, meane by estate, $\&$ servuyle by calling. This is a great confusion, \& a general disorder. ${ }^{36}$

In 1620, despite the fact that new sumptuary legislation had not been enacted for nearly twenty years, the anonymous author of Hic Mulier called upon "the powerful statute of apparel [to] lift up his battle-ax and crush the offenders in pieces, so everyone may be known by the true badge of their blood or fortune. ${ }^{37}$ Likewise, in 1628, William Prynne attacked those whose clothing did not reflect their social 
station and occupation. Although it was no longer illegal for people to dress outside their place, he argued that it continued to be immoral:

He that is a Christian indeed, is a man of another temper; His desire and labour, is to conforme himselfe to Christ in every thing: ... His Haire, and Habit, such as answeres His profession, and doe well become the Gospel of Christ ... His out-side, is consonant to His inside, and suitable to His profession ${ }^{38}$

When these writers composed their tracts, they appealed to the fact that their readers had a shared set of guidelines as to what clothes were appropriate to specific social classes and occupations, and railed against those who defied those guidelines.

Thus, despite the fact that some people did not adhere to the sumptuary laws before 1604 and nobody was required to afterwards, English men and women shared a well defined, widely understood set of rules governing apparel. The theatre of the era appealed to this set of rules to establish character in performance. As Jean MacIntyre and Garret Epp have argued, on the stage

who and what an actor represents must be accurately conveyed, so that the audience can understand the play; if the play requires inaccuracies, this has to be made clear. Real apprentices defied London's rules about plain clothing to parade as gallants, but stage apprentices (as in 1 Edward IV) wore regulation coats and statutory flat caps. ${ }^{39}$

MacIntyre and Epp further argue that the rules governing clothes continued to determine how costumes were understood onstage even after the sumptuary laws that defined them were repealed. ${ }^{40}$ Consequently, we can begin to understand how 
particular actors appeared on stage by examining the laws that established the apparel considered to be appropriate to their characters' social stations.

Just one year after assuming the throne, Queen Elizabeth issued a proclamation stating that violations in certain sumptuary legislation passed during the reign of Henry VIII and Mary would not be tolerated. Appended to this decree was an outline which clearly listed the rules that were to be followed. These rules dealt overwhelmingly with the fabrics that might be worn by those of particular rank. Only Earls or those of superior degree could legally wear cloth of gold or silver tinsel, satin, silk, cloth mixed with gold or silver, and sables. Viscounts and Barons might wear those fabrics in their doublets and sleeveless coats. Only Dukes, Marquises, Earls, and their children, and Barons and "Kyghtes or thorder" could wear woolen cloth made outside of England, Velvet that was crimson, scarlet or blue, and Fur that was of black jenets or luzernes. ${ }^{41}$ Those who were at least Baron's sons, knights, and men earning two hundred pounds per year could wear velvet in their gowns, coats and outermost garments; they could wear the fur of libardes and embroidery; their clothes could have pricking or prinking with gold, silver, or silk; and they could wear taffeta, satin, damask, or silk chamlet in their uttermost garments. A man earning one hundred pounds per year was permitted to wear velvet in jackets and doublets, and imported furs (except for gray Jenettes and bodge). Lastly, the "sonne and heyre, or daughter of a knight, or the wyfe of teh sayde sonne, A man that may dispende XX. Li. By yere, or is worth two hundred poundes in goods” may wear silk in their hat, bonnet, nightcap, girdle, scabbard, hose, shoes, or spur leathers. ${ }^{42}$ 
This 1559 list provides a very clear sense of how actors needed to appear on stage in order to personate characters of particular social stations. It specifies that fabrics and apparel that would have visually asserted the social class of the one who wore it. Queen Elizabeth issued the last such list in a 1597 proclamation:

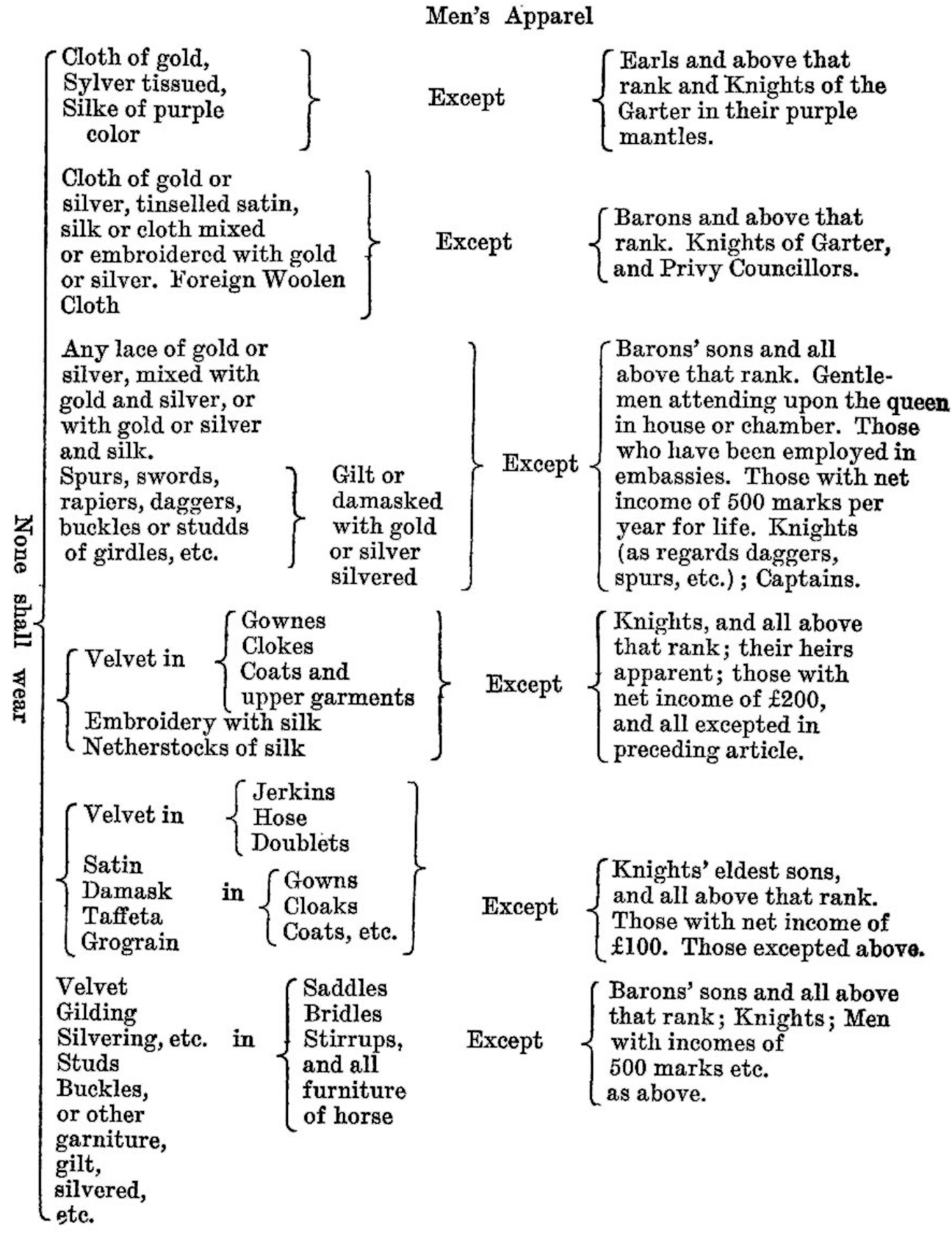

Image 7. 1597 Sumptuary proclamation. ${ }^{43}$

Continued 
Image 7 continued.

Women's Apparel

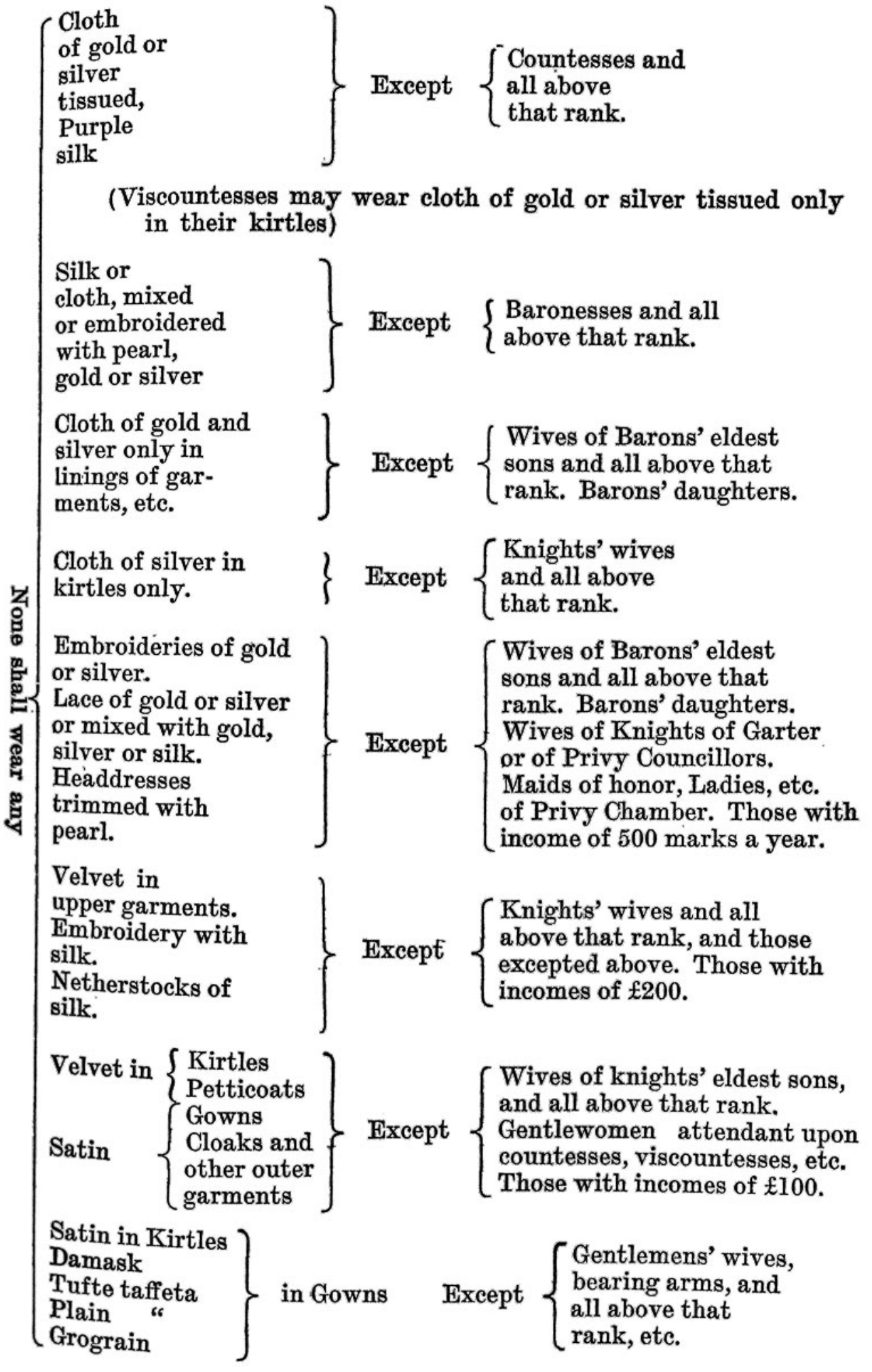


In light of the high cost of clothing at the time, it seems logical to assume that the acting companies worked primarily to establish the illusion of the apparel appropriate to particular classes and did not seek to purchase the exorbitantly expensive materials noted in this list, particularly those near the top of the social hierarchy. Support for the likelihood that theatre companies sought to cut costs by providing merely the illusion of expensive clothing can be found in Dekker's The Gull's Hornbook in which he says that by sitting on the stage, one may “examine the play-suits' lace, and perhaps win wagers upon laying tis copper. ${ }^{24}$ Copper lace was widely used in the theatre to imitate gold lace either to embellish clothing or to make old clothes seem new. ${ }^{45}$ And yet, the two property lists that survive from the period, Henslowe’s 1598 entry into his diary and Edward Alleyn's undated catalog of theatrical apparel (see Appendix A and B), show that the Admiral's Men also had a large collection of very expensive clothing that went beyond the illusion of sumptuousness. Jones and Stallybrass count 13 records of cloth of gold or cloth of silver; 32 records of garments with gold or silver lace; and a number of other garments recorded as having gold or silver trappings (fringes, spangles, etc.) or with gold or silver buttons. ${ }^{46}$ The plays presented on early modern English stages often have characters drawn from the highest levels of society, and the lists from the Admiral's Men suggest that the companies cut costs when they could, but often paid the high price necessary to provide the sumptuous costumes required to accurately dress the actors according to their character's station.

This dedication to the acquiring of costumes means that upon entering the stage a character's class would be known on sight to a high degree of specificity. No 
dialogue would be required to distinguish between a baron, an earl, and a king, for the actors' costumes would make this immediately apparent. These visual signifiers have major ramifications for how theatre at the time was likely experienced. Macbeth and Richard III can be understood to exist visually as plays about men who dared dress outside their stations and were destroyed for their presumption. King Lear, as other scholars have noted, is the story of a king who is reduced to nothing through the process of being divested of the clothes that establish his regal status. ${ }^{47}$

\section{Occupation}

When the characters being considered are further down the social scale, the project of determining what clothes signified one's station becomes a slightly more complicated historiographical undertaking. The term gentleman denotes a person who does not need to work to earn his living. Consequently, the sumptuary laws dealing with those above the rank of gentleman need not list the articles appropriate to individual occupations. Below the rank of gentleman, however, the sumptuary legislation considered thus far only suggests what one could not wear. To determine what was worn, attention must be focused on the particular occupations in England. Moreover, this study needs to expand to consider additional laws passed in early modern England and alternative forms of evidence. Unfortunately, pictorial evidence offers little help since paintings and portraits of members of the lower classes are rare.

In 1582 the Lord Mayor and common council of London, noting that apprentices were wearing clothes more sumptuous than their station, established 
specific rules detailing how one should and should not dress. Accordingly, an apprentice could not wear (1) any clothing except what he received from his master; (2) a hat, or anything except a woolen cap, (it could not have any silk); (3) ruffles, cuffs, loose collars, or anything except a ruff around his neck, and that must not be more than a yard long; (4) anything except canvas, fustian, sackcloth, English leather, or woolen doublets, (bearing no silver or silk trimming); (5) anything but white, blue, or russet kersey or cloth in his hose or stockings; (6) breeches made of any other materials than those of which the doublet was made, or stitched, laced, or bordered; (7) upper coats made of anything except plain cloth or leather, (it could not have pinking, stitching, edging, or silk trimming); (8) any surtouts except cloth gowns or cloaks, lined or faced with cloth, cotton or baize, with fixed, round collars, (it could not have stitching, guarding, lace or silk); (9) pumps, slippers or shoes not made of English leather, or pinked, edged or stitched, and girdles and garters made of anything except untrimmed crewel, wool, thread or leather; (10) swords, daggers, or other weapons, except knives, rings, jewels of gold nor silver, or silk in any of his apparel. An apprentice caught violating these rules could be punished at the discretion of his master for the first offence, publicly whipped for the second, and consigned to an additional six months of indentured servitude to his master for a third. ${ }^{48}$ These rules transferred directly to the stage: the woolen cap and statutory coat served as a visual signifier for apprentices, even after 1604 when they were no longer required attire.

Determining what was worn by the citizens in London is a little more difficult, but there can be no doubt that they would immediately be recognized as members of particular guilds, as aldermen, as sheriffs, or as Lord Mayors. In Julius Caesar, 
Flavius and Murellus are appalled to see citizens out in public without the clothes that denote their trades:

Flav. Is this a holiday? What, know you not, Being mechanical, you ought not walk Upon a laboring day without the sign Of your profession? Speak, what trade art thou?

Car. Why, sir, a carpenter.

Mur. Where is thy leather apron and thy rule?

What dost thou with thy best apparel on?

You, sir, what trade are you? (1.1.2-9)

Julius Caesar may be set in Rome, but the language of clothing is distinctively that of sixteenth century England. The clothes or apparel that identified particular trades were well known and offered an easy means of presenting information about a character.

Although Simon Eyre was a draper in the fifteenth century, he would have been immediately understood to be a shoe maker when he was seen onstage wearing a black apron ${ }^{49}$ and carrying “Saint Hugh's bones” (shoe makers’ tools). The gown Simon Eyre dons upon being made an alderman in The Shoemaker's Holiday is listed in the line notes as an "alderman’s gown." ${ }^{50}$ A sixteenth-century portrayal of Eyre in alderman's robes shows the apparel to be dark blue in color with baggy sleeves that taper at the wrist, ${ }^{51}$ although ceremonial occasions called for aldermen to wear robes of scarlet. Eyre is also shown wearing a stately cloak that reaches nearly to the ground. Upon being made sheriff, Eyre enters wearing a gold chain about his neck 
and notes the scarlet gown that marks his new degree, although the lines suggest he has not yet put it on (11.11-3). When Eyre appears in a scarlet robe, it marks his ascension to the rank of Lord Mayor. A change in costume constitutes a significant change in the character, demonstrating the ineluctable connection in early modern England between one's clothes and one’s identity. Simon Eyre’s ascension from shoemaker to Lord Mayor is accomplished through the donning of new clothes that carry a significance that apparel no longer holds today but must be understood to have had at the time.

In addition to acquiring new apparel, Simon Eyre also changes the color of the clothes he wears in a transition that would have been clearly recognized by early modern audiences as a movement from London blue to court scarlet. In early modern England, blue was the most common livery color, livery being the clothes prescribed by a gentlemen for his servants or by a tradesman for his apprentices. The connection between blue and livery was so familiar by the end of the sixteenth century that "blue coat" or "blue-aproned man" became the term for servants and apprentices. ${ }^{52}$

Tradesmen also commonly wore blue, and references from the drama suggest that it was sometimes difficult to tell who was the apprentice and who was the master. ${ }^{53}$ Scarlet, on the other hand, was the color of the court and was very expensive. ${ }^{54}$ Accordingly, the robe in which Eyre appears upon becoming Lord Mayor visually demonstrates the culmination of his movement from commoner to gentleman. True to the definition of a gentleman, Eyre discontinues manual labor in the course of becoming Lord Mayor and gives his shop and tools to Roger (10.143). 
Eyre's wife Margery is eager to assume the status of gentlewoman afforded her by her husband's advancement and, not surprisingly, she accomplishes this by purchasing the apparel appropriate to her new prestige: “art thou acquainted with never a farthingale-maker, nor a French-hood maker? I must enlarge my bum -ha, ha! How shall I look in a hood, I wonder?” (10.35-7). A farthingale is the ideal article of clothing for Margery, for its design precludes practical labor on the part of the wearer; more than any other piece of apparel, the farthingale is suited to women who do not need to work. Also, it is not surprising that she opts for a French hood, for wearing foreign fashions was the rage of the wealthy in early modern England.

Those lower on the social scale, particularly those who worked the land, wore clothes that could be identified more by their usefulness than by their fashionableness. Farthingales and ruffs were completely impractical. Similarly, the doublets and jerkins worn by laborers did not conform to the body or have a peascod belly. Rather, they were generally loose fitting. In the few pictorial representations we have of field workers and shepherds from the period, the jerkins are most often worn with a belt and end in an open, knee-length skirt. They would be made of canvas, fustian, or leather. A jerkin worn on top would similarly be loose on the body and would be made of cloth or buff (oiled ox-hide). ${ }^{55}$ In hot weather, however, laborers might wear nothing covering their shirts while they worked. ${ }^{56}$ Sometimes farm workers or shephards are depicted barefoot, but other times they wear boots. Wide breeches were uncommon among the lower classes for much the same reason that farthingales were not worn by women; they would have made work more difficult. 
And yet, women who worked the land wore skirts that were long and full throughout the period despite the likelihood that they complicated labor.

\section{Nationality}

The costumes worn on stage would also immediately establish if the character being portrayed were from another country. Evidence from the drama suggests that actors pretending to be characters from outside England were easily identifiable by the clothes they wore. Fashions identified as belonging to the Dutch, French, German, Italian, or Spanish would make a character's nation of origin obvious to English audiences. Determining what the actors might have actually worn, however, is much more difficult.

From the beginning of the sixteenth century, fashions spread quickly throughout Europe, with styles originating in one location being regularly worn by the wealthy in various countries. The intermarriage of royalty coupled with the growth of international trade introduced the elite throughout Europe to the fashions in other countries and encouraged the adoption of rapidly changing styles. From the mid- sixteenth century until the 1620s, Spanish tastes had a profound influence on European fashion. This sartorial influence derived largely from Spain’s financial and military power during this period. Dutch and French styles offered alternatives that were embraced by the wealthy of various nations and assumed preeminence after the decline of Spanish styles. ${ }^{57}$ That stated, the national styles in Europe became so widely diffused in the late sixteenth-century that it is often difficult to determine the nationality of contemporary portraits from the mere costume. The apparel that is 
depicted could signify that the individual is from England, France, the Netherlands, Spain, or Italy. ${ }^{58}$

The problem of identifying the style that belongs to a particular country is compounded when the object of study is the theatre and not early modern society. Were we interested merely in studying what styles were dominant in different countries, we could examine the fashions that prevailed in each, using the pictures, portraits, and documents of the era to piece together what was worn. This is different from determining the apparel that signified various nationalities on English stages. The set of theatrical apparel that established an individual as a native of a foreign country need not be an accurate reflection of the styles that were actually worn in the country being signified. In Much Ado About Nothing, when Don Pedro mocks Benedick's falling in love, he names particular articles of clothing that denote foreign styles:

There is no appearance of fancy in him, unless it be a fancy that he hath to strange disguises—as to be a Dutchman to-day, a French-man to-morrow, or in the shape of two countries at once, as a German from the waist downward, all slops, and a Spaniard from the hip upward, no doublet. (3.2.31-37)

Here Shakespeare provides an indication of the apparel that comprised German and Spanish styles on the stage. In contemporary portraits and paintings, German men are often shown wearing large, heavily paned breeches and it is perhaps to these that Don Pedro refers. However, there are no readily available Spanish pictures depicting a man without his doublet. Perhaps this was not the practice among the wealthy who 
appear in portraits, but was popular in Spain nonetheless. From the manner in which the fashion is mentioned in the play, we can be relatively certain that Shakespeare and his audience were familiar with it and accepted it as a Spanish style. Evidence that the practice of going without a doublet implied Spanish nationality can be found on the title page of the printed version of The Spanish Tragedy, published in 1615 (yet first performed between 1585 and 1589). This picture clearly shows Heironomo in breeches and a shirt, wearing no doublet. And yet, it is important to note that the scene of the play depicted on the cover (2.5), calls for Heironomo to wear only his shirt because he was just called out of bed. Is it possible that English playwrights and audiences expected Spanish men to go without their doublets because of this scene? Whether or not Spanish men actually went without doublets on occasion is immaterial to the fact that the fashion signified a Spanish style on English stages.

Lines from the plays offer pinpoints of illumination into the semiotics governing national styles on the English stage. Working on the assumption that the playwrights at the time perceived clothing in the same way as their audience, it would seem possible to piece together what clothes denoted particular nationalities by studying the clues provided in the drama. However, such an approach would yield problematic conclusions for it is based on the ahistorical premise that styles did not alter throughout the period. Fashions changed rapidly throughout Europe in the sixteenth and early seventeenth centuries. It would be imprudent to assume that the fashions denoting different nationalities on the English stages did not also change. For instance, the title page of Middleton's A Game at Chess (published in 1624) clearly shows a Spanish lord wearing a doublet. Consequently, a consideration of the 
apparel that denoted one's nationality on the English stage requires that one be mindful of the fact that just as fashions altered over time, so did the visual signifiers.

\section{Religion}

Whether on stage or in English society, one’s apparel could serve to establish visually one's religion. This is most true for the highly religious members of society: the representatives of the Catholic Church and the Church of England, and Jews. Priests, bishops, cardinals, popes, friars, nuns, ministers, and Jews were associated with particular clothes that would have clearly denoted an actor's religious role in the theatre.

England's separation from the Catholic church during the reign of Henry VIII caused a significant change in the apparel worn by English theologians. Catholic priests wore (and continue to wear today) special garments that served to sanctify the religious proceedings of the church, particularly the holy mass. A priest could wear a number of different articles of clothing depending on the religious function he was serving, whether it be for common wear, specific services, or Holy Mass.

Consequently, a priest would have been easily identified on the English stage by virtue of the clothes specific to his religious function. He would likely appear wearing an $a l b$, a white linen vestment with close fitting sleeves that reached nearly to the ground. This could have been worn over, and hidden, ordinary apparel. Around the alb, tied in at the waist, would be worn a girdle called a cincture. Next the priest might wear a surplice, a large-sleeved tunic of half-length, made of fine linen or cotton. On his head, a priest would likely wear a black biretta, a square cap. To depict 
a priest performing a ceremony, an English actor might choose to wear the most conspicuous Mass vestment, the chasuble, a square or circular piece of cloth that covered the whole body and had a hole in the center for the priest's head. The clothes a Catholic priest wore for mass were crucial to the service which effected the transubstantiation of bread and wine into the body and blood of Christ.

To indicate that an actor was playing a Catholic bishop, a cardinal, or the pope, the basic priest's apparel could be worn with a few significant changes. For instance, the biretta of a bishop was purple and that of a cardinal was scarlet. Or, instead of a biretta, the actor might wear a mitre, the ornamented, high peaked hat worn solely by Catholic bishops, cardinals, and the Pope. Henslowe’s diary mentions a "poopes miter" (see appendix A), which might have been worn in Dr. Faustus. Cardinals were easily identified by their scarlet attire. Thus, in Henry VIII, Surrey calls Wolsey “a piece of scarlet” (3.2.280). Also, Cardinals had a specific hat that denoted their rank which was scarlet in color, round, wide-brimmed, and had tassels. This hat was not always worn, but served as a symbol of one's rank. This explains why, in Henry VIII, Wolsey’s Cardinal's hat is carried before him in 2.4.

Friars and nuns similarly had apparel that was specific to their positions in the Catholic church and would have been easily identified on sight. Thus, in Measure for Measure, the Duke's use of disguise would have been a comic movement from aristocratic apparel to a simple robe, tied at the waist, with a hood. Dominican friars wore white robes with a black mantle on top. Carmelite friars wore white mantles over brown robes. Franciscan friars, wore brown robes. When Dr. Faustus tells Mephistopheles that he is too ugly and should return in the form of a Franciscan friar, 
it is likely he returned to the stage in a brown robe with a hood. A nun's habit similarly consisted of a simple robe, typically white (although sometimes including a black hood), tied at the waist, with a hood. Images from the period tend to depict nuns as wearing their hoods over their heads and Monks with their hoods pulled back.

The Reformation in England brought with it a change in the role of the clergy and a consonant change in their apparel. Protestantism's focus on the reading of the bible over ceremonies converted the church officials from intermediaries between man and God into teachers. Denying that transubstantiation actually took place in the Holy Mass, Protestant ministers did not need to wear the apparel that contributed to the ceremonial function. Indeed, Protestant ministers attacked the Catholic ceremonies as heresies and deliberately chose to wear different clothes. In accordance with their educational goal of the word of God, Protestant ministers began the practice of preaching in gowns like those worn by academics. Accordingly, in Bartholomew Fair, the puritanical preacher Zeal-of-the-Land Busy is noted to be wearing a "scrivener's furred gown." Thus attired, Busy looks the part when he issues his highly religious anti-theatrical attack: "Hold thy peace, thy scurrility, shut up thy mouth, thy profession is damnable, and in pleading for it, thou dost plead for Baal” $(5.5 .15-7)^{59}$ Busy does not merely speak the words of the puritanical preachers that attacked the theatres; he also dresses like one.

Although Jews were officially banished from England in 1290 and only legally readmitted in the eighteenth-century, some lived and traveled there during the Tudor and Stuart period. Most notably, Queen Elizabeth had a Jewish doctor, Roderigo Lopez. ${ }^{60}$ The clothes Jews wore while walking in England would not have 
easily identified them. ${ }^{61}$ Indeed, some of the fear surrounding Jews derives from their ability to look identical to Christians. However, when Jews appeared in plays of the period, including those by Shakespeare and Marlowe, they were visually identifiable by their gaberdine and their large nose. In The Merchant of Venice, Shylock says "You call me misbeliever, cut-throat dog, And spet upon my Jewish gaberdine" (1.3.112-3). A gaberdine was a long cloat, worn loose or girdled, with long sleeves that was owned by more than just Jews. The gaberdine has been described as being made of coarse material, ${ }^{62}$ but this is not necessarily true. Henry, Earl of Northumberland lists in his wardrobe a "gawbdyne of russet veluett ... gardytt with greene cloth of golde, and lyned with black sarcenett. ${ }^{\text {} 63}$ This proves that gaberdine’s could be made of very fine cloth and were sometimes worn by the nobility.

The large nose that would visually distinguish a Jew on stage is mentioned several times in Marlowe's The Jew of Malta. Ithamore says to the Jewish Barabas "I worship your nose for this” (2.3.179). Randall Nakayama argues that despite the connection of Barabas' nose to his Jewish identity, it is his apparel that more effectively identifies him: when Barabas assumes the disguise of a French musician, he is not recognized by his facial features. This leads Nakayama to conclude that "the sartorial is more powerful than the anatomical, that the dress is more important than the nose." ${ }^{64}$ Perhaps this is true. And yet, it is possible that the nose would be presented for the entertainment of the audience while the disguise was understood to be effective in the action of the play. The whole point of disguise is to let the audience know who the individual really is while the other characters in the play are tricked. 
For those who were not defined primarily by their religion (i.e., not Catholic or Protestant clergy, or Jews), it would still have been possible to present the visual signifiers of one's religious affiliation. For Catholics, the carrying of a crucifix or rosary beads would immediately suggest one's religion. A 1608 drawing of an actor (identified by R. A. Foakes as Robert Green in the role of No-body from the anonymous No-body and Some-Body) shows him carrying rosary beads. In the intimate setting of the indoor and outdoor theatres where no spectators were beyond easy viewing distance of the actors, rosary beads would have been clearly visible on stage.

A character's Protestant beliefs could have been highlighted by having him or her appear carrying the English bible. As Patrick Collinson explains, "some time between the middle of the reign of Elizabeth and the meeting of the Long Parliament in 1640 the English became the people of a book, and that book was the Bible." ${ }^{\text {,65 The }}$ association of Protestantism with the bible must have been made near the beginning of this period, for drawings from the late sixteenth-century repeatedly present Protestants with the bible in their hands. ${ }^{66}$ In a 1569 anti-Protestant satire, the bible is conspicuous in the hands of all of the people being attacked: 


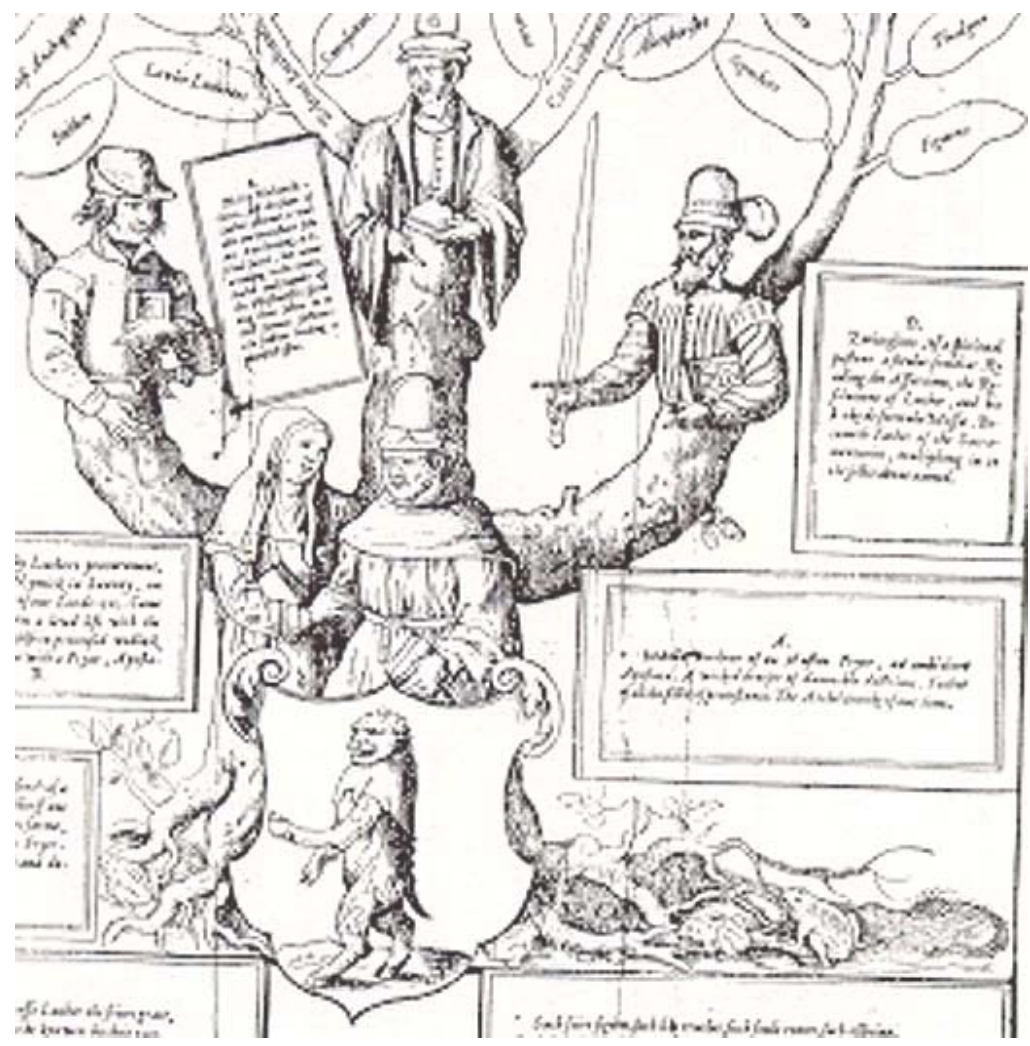

Image 8. Anti-Protestant illustration. ${ }^{67}$

Whether presenting an actor as a member of the clergy, a Jew, or simply a committed Protestant or Catholic recusant, the Shakespearean stage had recourse to a well understood visual vocabulary regarding religion.

As this chapter has sought to show, the early modern culture was deeply invested in guaranteeing that one's identity be accurately presented in the clothes one wore. The result was a set of visual codes that was understood by both playwrights and audience members at the time, and should be considered in examinations of English drama. Accordingly, the following chapters will attempt to determine how these codes were employed to create meaning in early modern English performances. 


\section{CHAPTER 2}

\section{STUART MASQUES}

The vital manner in which apparel served to establish one's identity in early modern England suggests that the costuming practices employed in the various theatrical productions of the period constitute a crucial area of study. And yet, it would be unjust to suggest that such an analysis would amount to an entirely new avenue of exploration. The costumes employed in the Jacobean and Caroline masques have received a fair amount of consideration.

In many cases, however, the attention devoted to the clothing worn by the participants in the masques has been only grudgingly acknowledged by scholars who see the literary aspects of the event as the most deserving of study. In the most recent compilation of essays dedicated to the Stuart court masque, the editors admit their own literary predisposition in their introduction:

Our emphasis is designedly literary, though with careful attention as well to dance and music ... This book devotes rather little attention to visual aesthetics of the masque, to the machinery and stunning trompe l'oeil effects that so impressed eyewitnesses. Perhaps despite its interest in a cross-disciplinary genre, this book is ultimately wedded to 
a literary and even Aristotelian preference for theme and idea over spectacle. ${ }^{1}$

Regardless of New Historicism's stated desire to consider the full range of cultural practices, the focus of most studies of the masque remains tightly grafted to the written word.

Interestingly enough, the written word of the masque provides strong encouragement to consider the visual codes employed in production. In the introduction to Shakespearean Negotiations, Stephen Greenblatt proposes that we "look less at the presumed center of the literary domain than at its borders, to try to track what can only be glimpsed, as it were, at the margins of the text." ${ }^{22}$ In the published editions of most of the masques, the literal borders of the written dialogue consist of extensive stage directions, including careful documentation of the costumes that were employed in production. This practice of documenting the performance begins, ironically enough, with Ben Jonson, the great early modern champion of poetry over spectacle.

In his Works of 1616 and 1640, Jonson includes more than just dialogue for the 25 masques he wrote. He also details numerous descriptions of the costumes worn by the performers. Moreover, these descriptions do not appear all at once in a preface or appendix. Rather, throughout the texts of the masques, Jonson depicts the costumes worn in production. This information appears immediately before the character enters upon the stage. Thus, in simply reading the masques in Jonson's compilations, one is forced to engage the visual codes of the production. For instance, in Hymenaei, the 1606 masque provided to celebrate the marriage of the Earl of Essex and Frances 
Howard, daughter of the Earl of Suffolk, Jonson begins with a rich description of the scene:

On the night of the masques (which were two, one of men, the other of women) the scene being drawn, there was first discovered an altar, upon which was inscribed in letters of gold,

IONI. OIMAE. MIMAE.

UNIONI

SACR.

To this altar entered five pages attired in white, bearing five tapers of virgin wax; behind them, one representing a bridegroom, his hair short and bound with particolored ribbons and gold twist, his garments purple and white.

On the other hand entered Hymen, the god of marriage, in a saffron colored robe, his under vestures white, his socks yellow, a yellow veil of silk on his left arm, his head crowned with roses and marjoram, in his right hand a torch of pine tree.

The list continues, with each character's apparel and visual presentation made an ineluctable element of the written masque. Indeed, Jonson's text of Hymenaei seems to give preference to the visual codes over the dialogue by beginning with the costumes and settings and then providing speech afterwards. What makes this attention to apparel and locale even more poignant is the fact that, in the preface to Hymenaei, Jonson argues that the importance of the masque is to be found not merely in the "riches and magnificence in the outward celebration or show," but in its 
"inward parts, and those grounded upon antiquity and solid learnings; which, though their voice be taught to sound to present occasions, their sense or doth or should always lay hold on more removed mysteries.”3 In the context of the rest of his introduction, Jonson here argues that the meaning of the work is to be found in the "removed mysteries," the philosophical profundity of the work, and not in the spectacular elements of performance geared toward celebrating the particular occasion of the masque. How then are we to reconcile Jonson's desire for philosophical depth and his decision to include in his Works a detailed enumeration of the visually-based elements of production?

Stephen Orgel and Roy Strong note that the antithesis between visual and verbal experience did not exist in the Renaissance in the way it does for us today. "There was for Jonson a basic connection between the image and the word, and truth was lost when picture was rejected. ${ }^{, 4}$ For the early modern artist, there was a tight relation between verbal statements and visual representations. Jonson explains in Timber, or Discoveries:

Poesis, et Pictura. Poetry, and Picture, are Arts of a like nature; and both are busy about imitation. It was excellently said of Plutarch, Poetry was a speaking Picture, and Picture a mute Poesy. For they both invent, feign, and devise many things, and accommodate all they invent to the use, and services of nature. Yet of the two, the Pen is more noble, than the Pencil. For that can speak to the Understanding; the other, but to the Sense. ... Whosoever loves not Picture, is injurious to Truth: and all the wisdom of Poetry. ${ }^{5}$ 
This mutual respect for picture and poetry explains the period's interest in hieroglyphs, the form in which image and word are united. ${ }^{6}$ Thus, the "removed mysteries” which Jonson underscores as the purpose of the masque is not something to be sought in the words alone, for to do so is to privilege the literary aspects of the masque in a way that is anachronistic. The visual elements deserve equal consideration. Moreover, their consideration should be geared toward understanding the manner in which they contribute to the "removed mysteries" of the masque and not merely to its spectacular appeal to the senses. According to this figuration of the close relation between the visual and the verbal in early modern England, even if one makes Ben Jonson's composition of the masques the subject of study, one ought to consider the visual codes to which the author devotes considerable space and attention.

Of course, the Stuart masque was, from its very inception, intended for performance. One examination of the Stuart masque that attempts to consider its literary elements in tandem with its skillfully designed sets and deft costume construction was co-authored by two scholars from the disciplines of English Literature and Art History: Stephen Orgel and Roy Strong. Their two-volume book, Indigo Jones: The Theatre of the Stuart Court remains required reading for all who are interested in studying the masque. Perhaps their most important contribution to the further study of the masque is their diligence in bringing together, in this single work, so much information crucial to examining the masque as a blending of different genres. First, they reproduce all of the extant texts of the masques designed by Inigo Jones, including pieces written by Ben Jonson, Thomas Campion, Samuel Daniel, 
George Chapman, Aurelian Townshend, James Shirley, Thomas Carew, and William Davenant. Next, they list all of the available information regarding the cost of the masques, including the price of costumes, materials to make apparel, and set pieces. They also include all of the contemporary commentary on the masques. And finally, Orgel and Strong provide reproductions of all of the surviving drawings of sets and costumes by Inigo Jones.

These costume drawings by Inigo Jones, numbering in the hundreds, offer one of the strongest argument for serious consideration of the apparel worn in the Stuart masque. It must be remembered that, as royal entertainments, the Jacobean and Caroline masques were all but defined by their particular use of costume. The very term "masque" alludes to the particular article of clothing, the mask or vizard, which was worn by the aristocrats who took part in the performance by dancing. It typically covered much of the individual's face (but was not always intended to hide one's identity) and served to connect a member of the court to the world of the performance. More importantly, however, was the fact that the vizard was part of the extravagant costumes that were an essential element of all the masques. Inigo's drawings show that from his first involvement with the Stuart masques, he considered his work on the masquers' costumes to be of paramount importance. Also, the number of sketches we have of his costumes increases through the course of his career, offering the possibility that, over time, he devoted even more of his efforts towards the creation of apparel for his masquers. 
Keith Sturgess, in his attempt to locate the inspiration for Inigo's costume drawings for one particular masque, Coelum Britannicum, identifies four design principles at work:

There is a basic iconographic shape which suggests 'antique hero', made up of part Roman and part Ancient Briton. The choice of colours and materials is determined by the need to catch, reflect and be enhanced by candle- and torchlight. The style is intended to promote physical ease for the dancing and to show off the leg. And the cost of material and the richness with which it is decorated must suggest magnificence. $^{7}$

Beyond informing the apparel worn in Coelum Britannicum, these four basic design principles figure significantly in all of the costumes that Inigo Jones provided for the Stuart Masques.

First, Jones created his costumes for a court that was familiar with allegorical art. $^{8}$ While developing his costume designs, Jones borrowed extensively from Cesare Ripa’s Iconologia and the 1598 edition of Cesare Vecellio’s costume manual. ${ }^{9}$ In these works, he found prints and detailed explanations for the various allegories of virtue and vice that he put into his masques.

The level of description accompanying these Italian prints suggests that many who read them could not, in fact, identify them on sight. After all, there is no reason to provide an explanation to one's drawings if the anticipated audience already understands the iconography. Moreover, the fact that these books were written in Italian at the end of the sixteenth century suggests that many watching the English 
court masques would have found themselves unfamiliar with and confused by what they saw. For scholars attempting to understand masque iconography today, Allan Gilbert's The Symbolic Persons in the Masques of Ben Jonson is a useful resource. ${ }^{10}$ But there is little way to determine whether the characters in the masques were able to be identified by their costumes in the original performances .

The writers of the masques seem to have recognized this potential problem. In response, they frequently provided spoken cues that served to fill in the potential gaps in the audience's understanding of the costumes' iconographic meaning. For instance, in Hymenaei, the identities of all of the characters in the masque are mentioned in dialogue or song. Shortly after Hymen appears onstage, the Chorus introduces him to the audience in lyrics: "Fly then, all profane, away, / Fly far off, as hath the day; / Night her curtain doth display, / And this is Hymen’s holiday” (66-9). Jonson’s line notes read that "the song being ended, Hymen presented himself foremost, and after some sign of admiration began to speak" (74-5). Armed with knowledge of who Hymen was, the audience could fully appreciate the saffron colored robe that was his customary attire. ${ }^{11}$ In addition to his robe, Jonson notes that Hymen wore undervestures that are white (likely a linen shirt that was visible), yellow socks (stockings), a yellow veil of silk on his left arm, a crown of roses and marjoram on his head, and a torch of pine tree in his hand. The yellow stockings naturally, and correctly, bring to mind Malvolio’s apparel in Twelfth Night. They are the proper items for one who is in love and are naturally abhored by Olivia who has renounced love and marriage for seven years, when her period of mourning for her dead brother will have ended. 
Later in Hymenaei, when Reason is about to appear, the lines Hymen speaks guarantee that the new character's identity will be understood: "If there be / A power like reason left in that huge body, / Or little world of man, from whence these came, / Look forth, and with thy bright and numerous flame / Instruct their darkness, make them know and see, / In wronging these, they have rebelled 'gainst thee” (italics mine 114-18). After being identified, Reason presents herself to the audience. Along the same lines, the four humours and affections only enter upon the stage after Reason has informed the audience of their identities: "For none but humors and affections would have dared so rash a venture” (129-30).

On 7 January 1606, John Pory related the events of Hymenaei to Sir Robert Cotton in a letter in which he describes, in some detail, the characters who appeared on stage: " $w^{\text {th }}$ in the Concaue sate the 8 . men-maskers representing the 4 . humours and the fower affections which leapt forth to disturb the sacrifice to vnion: but amidst their fury reason that sate aboue them all ...”12 Did John Pory understand the figures on sight or did he need to learn their identities from the dialogue? We can never be sure. But the character information, provided in the song and speech of the performance, offers a compelling alternative to the erudition of the audience in explaining the level of Porry's understanding. The fact that Pory supplies no information about the characters that is not actually stated in the masque suggests that, for him, the iconographic aspects of the costumes needed to be explained. ${ }^{13}$

Allardyce Nicoll argues that a great deal of the audience's pleasure would have been gleaned from being able to decipher the iconography employed in the production. To explain, he notes that the audience watching Davenant's 1637 masque, 
Britannia Triumphans, would have seen on the side of the proscenium "a woman in a watchet drapery, heightened with silver, on her head a corona rostrata, with one hand holding the rudder of a ship, and in the other a little winged figure with a branch of palm and a garland" (39-42). Nicoll writes "how proud and delighted must have been those who, having read Cesare Ripa's Iconologia, were able to identify the figure for their neighbours. In Ripa they would have read that 'Vittoria Navale’—naval victory personified — was to be figured as 'a winged woman, standing upon the prow of a ship, holding a crown in her right hand and a palm in the left." ${ }^{14}$ No doubt Nicoll correctly identifies the character, but it would be going too far to suggest that most of the members of the audience were familiar with Ripa's Iconologia. After all, even in the written text of the masque, Davenant makes sure to identify the character that he has just described, stating quite plainly for those who did not understand the iconography: "this woman represented Naval Victory" (42) ${ }^{15}$ Moreover, as we see in Jonson's Hymenaei, all of the characters in Britannia Triumphans are introduced in the song and dialogue of the masque so that they might be known by those who are unable to determine their identity by their costumes alone.

Thus, in Britannia Triumphans, when Imposture enters, his character is identified for the audience: “variable sir, i'th' name of heaven, / What makes your falsehood here where Fame intends / Her triumphs all of truth?” (71-2). Similarly, before Merlin appears, Imposture introduces him: "The great devourer of mysterious books / Is come, Merlin” (192-3). Next Bellerophon, is called by name and briefly described before he enters the scene: "Bellerephon! Thou that the offspring art of 
heaven” (176). Each of the characters enters the scene only after the spectators have been provided an informative introduction.

Jones employed a richly iconographic vocabulary for the costumes he designed for his masques, but took pains to make sure that his visual information was clarified for his audience. As Orgel has noted, in early modern England, "every painting - even a portrait - had its moral or allegorical meaning; every emblem had its motto," but "it is a mistake to assume that the Renaissance audience, unlike a modern one, knew without being told”16 Additionally, rather than simply recreating what he found in Italian costume books, Jones regularly elaborated on the drawings he found in his sources, accentuating their designs in order to make the costumes more sumptuous. Thus, Jones may have based his work on designs made by others, but deserves primary credit for constructing the visual world of the masque.

The colors that Jones employed for his costumes, Orgel and Strong note, were mainly white and gold, green and silver, carnation and watchet (light or pale blue inclining toward green). ${ }^{17}$ These colors would reflect the most light and appear splendid in the illumination provided by the torches employed in masques. This selection of colors mirrors the recommendation made by Francis Bacon in his 1625 essay "Of Masques and Triumphs.” There, he states that "The Colours that shew best by Candle-lights are White, Carnation, and a Kind of Sea-Water-Greene.," ${ }^{, 18}$ The colors used in the individual masques are usually mentioned in the descriptions of the costumes that precede the appearance of particular characters onstage. Thus the text of The Masque of Blackness notes that the masquers' arms and face are painted black, but their costumes are of azure and silver. 
To help the audience view the masquers and the splendor of their costumes, Jones kept the stage well illuminated. This may seem an obvious choice, but it likely served to hinder the special effects that Jones frequently employed in the Masques. As Robert Graves explains, in the early modern period "to produce a striking effect with colored light ... the general illumination must be kept dim.." ${ }^{, 19}$ Graves goes on to note that this fact was already well established by the Italian designer Leone di Somi in the mid-sixteenth century. Jones employed a range of lighting techniques to heighten the spectacle, but not at the expense of the visibility of the courtiers who were performing. On the other hand, Jones was fond of dark scenes at the beginning of his masques, ${ }^{20}$ especially when the anti-masque was performed by non-actors and the costumes were less sumptuous and less significant.

Armed with the masque texts and their rich descriptions of the costumes, we can know, with a fair degree of certainty, what colors were employed in the original productions. What is not so easy to determine is who was responsible for the color choices. Jones’ early drawings are occasionally in color (there are seven extant colored sketches), and some are annotated with color notes, suggesting that, for those masques, he played a significant role in determining what colors would be used for the costumes. Jones' drawing of the costume worn by Anne, Lady Winter, third daughter of the $4^{\text {th }}$ Earl of Worcester in the 1609 Masque of Queens (image 9) offers an example. Across the top of the drawing, in brown and black ink, appears: Lady Wynter (Camylla struck out) / Candace Queen of the (Volsei struck out) Ethiops; to the right: deep flamcoler / Peche coler / Pale watched; colors further indicated with lines to various parts of the dress: upper sleeves pink Color and peche Co(ler) 
(watchut struck out); lower sleeves pall watchut bases: Peche Co. petticoat:

watchut. $^{21}$

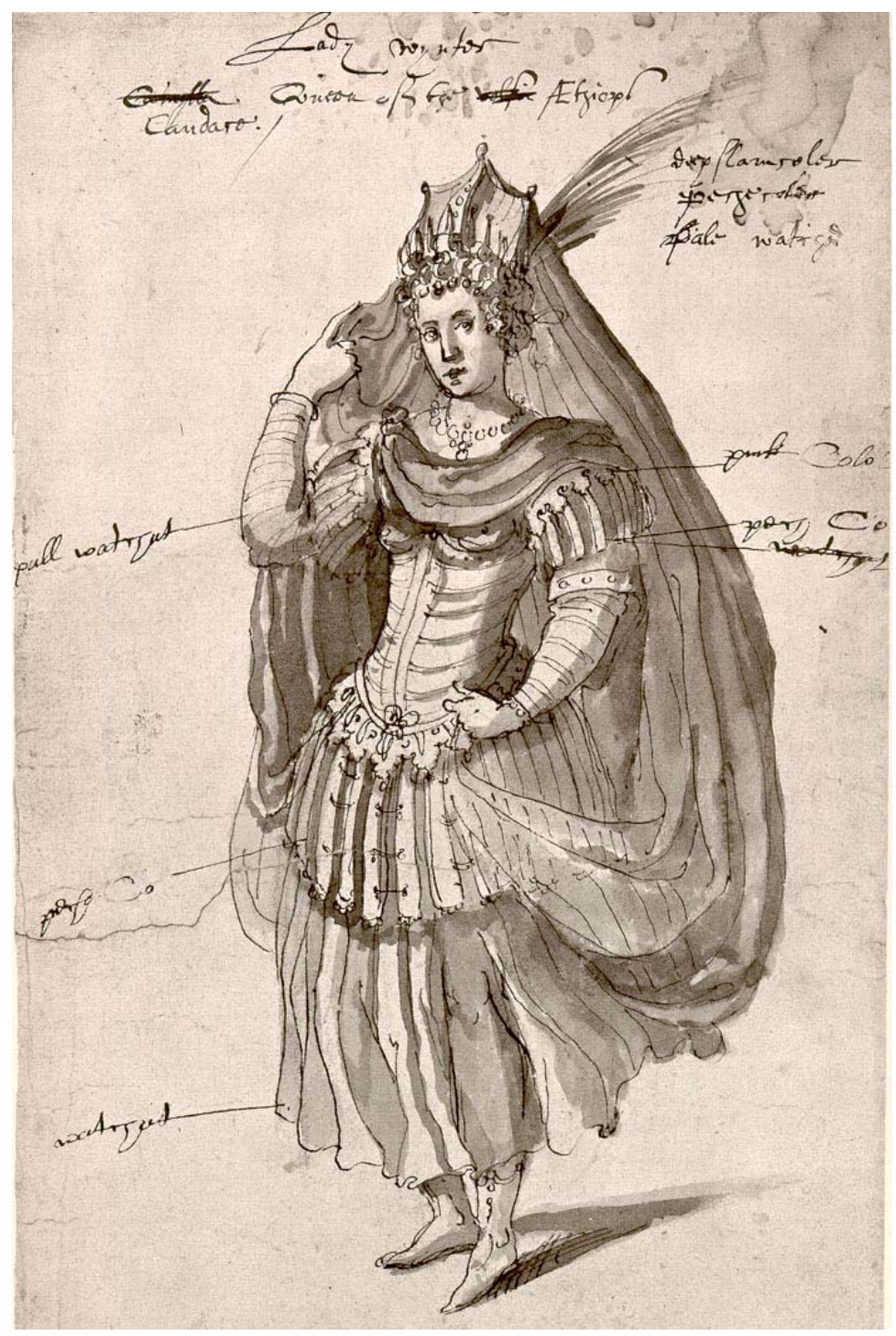

Image 9. Masque of Queens. ${ }^{22}$

In his later drawings, Jones rarely includes any information regarding the color of the costumes. Rather, they uniformly appear in brown or gray. No doubt color was coordinated to guarantee that the masques presented coherent visual ensembles, but only limited evidence is available. One important piece of information 
appears on the back of a drawing for the magicians that appear in the 1635 masque, The Temple of Love. There we find a long description of the costumes that appear on the reverse. Providing details of cut and color, it could very well be representative of information regularly provided to tailors.

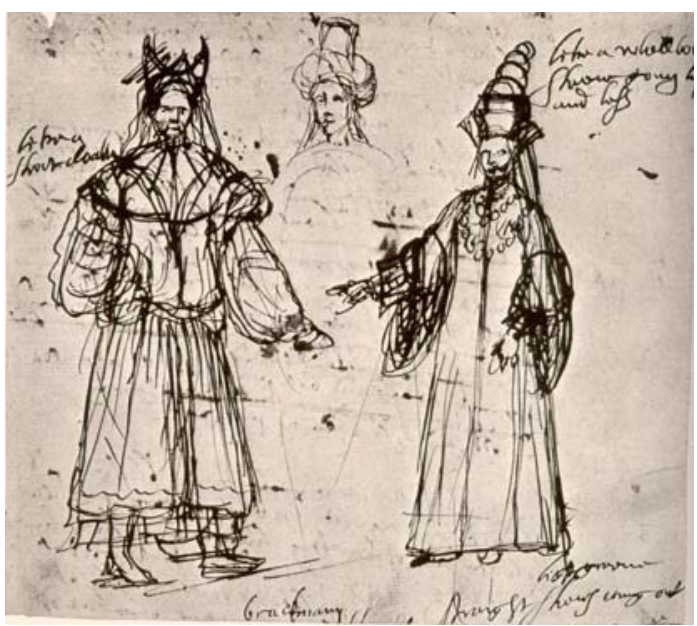

Image 10. Temple of Love. ${ }^{23}$

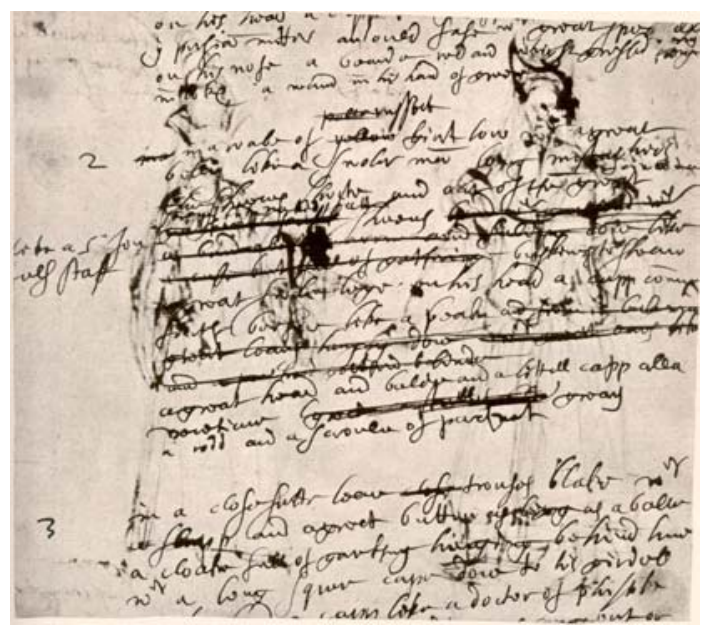

Back side.

Also worth noting are the inscriptions that appear in Jones’ drawing of Queen Henrietta Maria’s costume for the 1631 masque, Chloridia. On the side of the design, colors are listed with lines connecting them to particular articles of apparel: "green, whight, whight, green.” On the bottom, it states: “This designe I conceaue to bee fitt for the invention and if it please hir Maijestie / to add or alter any thing I desier to receaue hir majesties command and the dessigne againe by this bearer. The collors allso are in her majesties / choise; but my oppinion is that seueral fresh greenes mix with gould and siluer will bee most propper.”24 If this dialogue between the Queen and Jones is taken to be representative of normal practice, then the Queen had 
significant say in both the form and color of the costumes she wore and should be considered as a constituent creative voice in the creation of the masque.

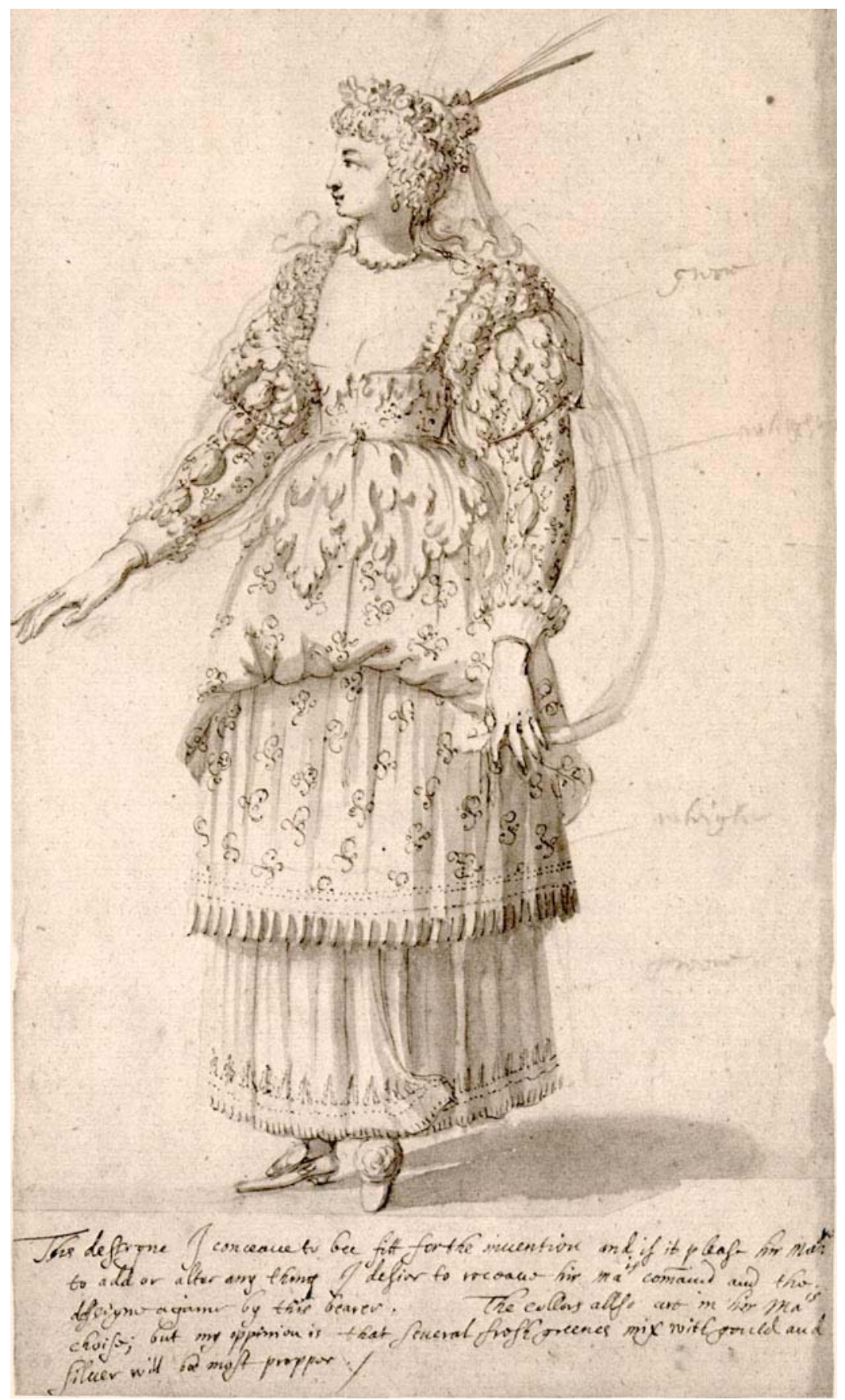

Image 11. Chlorida. ${ }^{25}$ 
In 1981, Orgel argued that court masques should properly be viewed as genuine collaborations between the artists and the patrons, ${ }^{26}$ and in the construction of the costumes worn in production, this seems particularly true at least in some cases. In a much more recent discussion of the court masques, Orgel provides further evidence that patrons had an important voice in deciding the form and color of the costumes that were worn. He notes that the costume worn for Hymenaei by Lucy Harinton, Countess of Bedford differed markedly from that which was designed by Inigo Jones and described by Ben Jonson in his text of the play. Jonson writes: "the upper part of white cloth of silver wrought with Juno's birds and fruits; a loose undergarment, full gathered, of carnation, striped with silver and parted with a golden zone; beneath that another flowing garment of watchet cloth of silver, laced with gold ...” (580-84). Unlike this description, the portrait of the Countess in her masque apparel shows her to be wearing a single skirt, not the two prescribed for her. Other portraits of masquers show that their costumes more closely fit Jonson's description. However, the Countess of Bedford paid for her costume and had it constructed by her own dressmaker according to her preferences. ${ }^{27}$

Keith Sturgess' third design principle for the masque requires that the apparel worn by the courtiers serve "to promote physical ease for the dancing and to show off the leg." This might seem common sense for an entertainment that was, for all its dramatic elements, an opportunity for the courtiers to dance. A view of the designs for the men's costumes suggests that they were deliberately made to emphasize the shape of the leg by covering only the upper leg. And yet, the fashion of the day was not dissimilar in form or function. The breeches and stockings that were the common 
articles worn on the lower half of the men's body can likewise show the leg to best advantage. That stated, there is textual evidence supporting the likelihood that the costumes were constructed with dancing in mind. In the Britannia Triumphans there is a telling comment on the costumes worn by one of the masquers: "This habit was beautiful, rich, and light for dancing, and proper for the subject of this masque” (5445). Further textual evidence is not available, but the costumes were likely constructed to accommodate the needs of the dancers.

Sturgess' final design principle for the costumes worn in the Stuart masques states that "the cost of material and the richness with which it is decorated must suggest magnificence.” This is the most important of the principles determining the form and composition of the apparel worn in the masque. To begin with, the costumes worn by the masquers were custom designed by Inigo Jones for each production. The amount of money expended on the materials and manufacture of the apparel worn by the royal family fairly boggles the imagination. As Orgel and Strong note, the Queen's silkman's bill for gold and silver braid alone for Tethys, the 1610 masque, came to an astounding $£ 1,984.8 \mathrm{~s} .2 \mathrm{~d} .{ }^{28}$ This amount can be put into perspective by noting that it cost about $£ 1,400$ to rebuild the Globe playhouse after it burned to the ground in 1613. Some of the surviving accounts for suits made for Prince Charles further suggest the opulence of the masque costumes:

1617 Vision of Delight - three suits - £249.16s.11d.

1620 News from the New World - three suits - £205.17s.7d.

1622 The Masque of Augurs - three suits - £78.7s.9d.

1623 Time Vindicated - two suits - £93.12s.21/2d. 
1624 Neptune’s Triumph - two suits - £171.19s.6d.

1634 Coelum Britannicum - one suit and a pattern for a page - £107.12s.5d. ${ }^{29}$ For the masques for which we have no record, it seems safe to assume that the costumes for royalty were no less expensive.

The courtiers who took part in the Jacobean masques were provided with the designs and color schemes of their costumes and were responsible for having them constructed. No doubt some courtiers found the cost excessive, but in much the same way that the masques served to emphasize the preeminence of the monarch, so did they mark those aristocrats permitted to take part in the performance as belonging to an elite circle. It was an honor to be permitted to pay the lavish fees necessary to guarantee that one's costume was appropriate to the royal spectacle. And, like the Countess of Bedford, courtiers could sometimes take liberties with their costumes and have them modified according to their wishes. That stated, it must have been understood that altering one's apparel too much would threaten to locate the wearer outside the dramatic world of the masque and likely displease the monarch.

In Charles' reign, financial records suggest that the crown most often paid for the costumes worn by the masquers. In the masque of 1626, Artenice, payment is made for nineteen gowns "for the Queene, and the Ladyes that attended her in the said Masque.”30 This change in policy would have cost the monarchy more money but permitted it greater control over the visual presentation of the whole by placing full responsibility for the design of the costumes in the hands of the King, the Queen, and Inigo Jones. ${ }^{31}$ Before larger conclusions are drawn from the fact that Charles paid for the masquers' costumes, it must be recognized that less money was typically spent 
on the Caroline masques than on their Jacobean predecessors. In those instances where financial evidence is available, we find comments like “Order to pay $£ 300$ for masquers' dresses, the King's and on whomsoever he cares to bestow them.”32 Despite the change in policy, it appears that some of the costumes for the masque remained the responsibility of those taking part in the performance. After 1634, there is no evidence that Charles paid for the costumes worn by others, but there is also none that suggests he did not. It seems likely that he maintained his earlier policy of paying for the apparel worn by the primary masquers.

The young nobles who appeared onstage as torchbearers, on the other hand, were consistently required to purchase costumes specifically made for the particular event. This policy remained unchanged through the reigns of James and Charles. The payments made for Lord Cranborne’s suit as a torchbearer in Coelum Britannicum are extant: ${ }^{33}$

The charge of a Masking suite for my Lord Cranborne is (viz.) by

$\begin{array}{lc}5 \text { yards half of carnation satten at 15s } & 04-02--06 \\ 3 \text { ells of whit tafatie for it at } 14 \text { s per ell } & 02-02- \\ \begin{array}{l}\text { 1 ell of white florence sarsnet at 10s } \\ \text { Silver buttons \& silke to the suit by bill }\end{array} & -09- \\ \text { For Imbroydering suit cappe and buskines } & 05- \\ 2 \text { yardes halfe of white callikoe to it by bill } & 06 \\ \text { Peeter Lehuk bill for fationing it } & 06-08-06 \\ \text { The taylors bill for making it upp } & 02-\end{array}$

Taken together, it cost £20.14s.6d. to make Lord Cranborne’s costume. 
Of note, the costumes worn in the anti-masque are almost uniformly made of far less expensive material than those worn in the masque proper. There are listings of prices for actors’ and anti-masquers' costumes for several masques (all from before 1630): the lost entertainment given by Lord Salisbury, Oberon, Love Freed, Pan's Anniversary, and the missing Queen's masque of 1627. These, Orgel and Strong note, reveal an abundant use of taffeta and sarcenet, tinsel and copper lace, satin and tiffany. ${ }^{34}$ In the records for the 1620 masque, Pan's Anniversary, or the Shepherds' Holiday, there are extensive listings of the prices paid for the costume items and properties of the anti-masquers. For sixteen listed individuals, the total comes to $£ 38.12$ s.10d. Why was so little money expended for those performing in the antimasque when they actually had dialogue and served to develop the drama?

The answer lies in the purpose of the masque. The Stuart masque was intended, first and foremost, to make manifest the magnificence of the monarch and his court. The anti-masquers were not a part of that court. Quite the opposite, they were actors, mere commoners, who were first invited to play a part in 1609 in The Masque of Queens when Queen Anna commanded Ben Jonson “to think on some dance or show that might precede hers and have the place of a foil or false masque.”35 Accordingly, although they spoke the lines in the performance and were highly visible, their significance was mediated by their primary purpose which was to highlight, by contrast, the quality of the court in the masque. Inigo Jones embraced this purpose by focusing his attentions on the costumes worn by the royalty. Indeed, late in his career, Jones refused to relinquish control over all of the masquers’ costumes, even when he assigned the responsibility for the anti-masquers and 
attendants to assistants. ${ }^{36}$ Furthermore, Sturgess notes that costumes for these lesser figures was often provided by the Revels office and was not always newly made for the particular performances. ${ }^{37}$

The sumptuousness of the costumes worn by the masquers and the care put into the apparel's production was directly tied to the fact that, unlike the individuals performing in the anti-masque, those taking part in the masque proper were not actors. As Orgel explains in The Illusion of Power, "to the Renaissance, appearing in a masque was not merely playing a part. It was, in a profound sense, precisely the opposite. ... a deep truth about the monarchy was realized and embodied in action, and the monarchs were revealed in roles that expressed the strongest Renaissance beliefs about the nature of kingship.”38 An important part of the belief of kingship in early modern England was the one that prompted the sumptuary laws. These royal proclamations dictated that one's apparel should denote one's social station. Although the sumptuary laws were dismantled in 1603, the widespread belief that one's social status should be visible on sight continued in early modern England. Accordingly, in the public spectacle of the masques, the royalty onstage, as well as all of the individuals taking part, should be understood to have simultaneously inhabited both the dramatic world of the performance and the nominal world of the English court.

The masque performance differed from the performances in the public playhouses in the fact that the rules governing the world of the court remained in effect throughout the event. Whereas professional actors might enter a liminal world on the public stages and assume identities entirely different from their own, the participants in the masque did not seek to shuffle off their court-based identity. Orgel 
states, "masquers are not actors; a lady or gentleman participating in a masque remains a lady or gentleman, and is not released from the obligation of observing the complex rules of behavior at court.. ${ }^{39}$ Francis Bacon provides an early modern articulation of this notion in his discussion of the masque: "let the suits of the masquers be graceful, and such as become the person, when the vizors are off." ${ }^{, 0}$ The only clothes that "become the person" of the members of the royal family are those which are of the richest variety. Moreover, it would, in fact, be unseemly for ones so exalted in rank to appear in anything less, for to do so in a performance that was commonly attended by foreign diplomats would be to suggest that the English monarchy was unable to afford finer clothes. It would amount to a public admission of inferiority, for as Richard Halpern notes, "the power of sovereignty work[ed] primarily by making itself visible." ${ }^{\text {41 }}$ By employing clothes of extraordinary opulence, the English monarchy did not merely demonstrate its wealth and magnificence, but actually established it. David Bevington and Peter Holbrook explain, "in the early modern court, prestige was either visible or non-existent." Commentary from the period makes it clear that the Stuart court was highly successful in establishing its prestige through the use of magnificent costumes in the masques. Responses from both Englishmen and foreigners mention the construction and lavishness of the costumes and the richness of the visual spectacle more than any other aspects of the masques. In his discussion of Hymenaei, one English audience member noted that "The men were clad in Crimzon, and the women in white. They had every one a white plume of the richest Herons fethers, and were so rich in jewels upon their heades as was most glorious. I think they hired and borrowed all the 
principal jewels and ropes of perle both in court or citty." ${ }^{, 43}$ For The Masque of Queens, La Boderie, the French Ambassador, wrote “Le dit ballet fut fort riche \& s'il m'est loisible de le dire, plus superbe qu'ingenieux.. ${ }^{, 4}$ Contemporary response to The Lords' Masque was actually fairly negative, with the one exception being the reception of the visual spectacle. John Chamberlain wrote "That night was the Lords maske whereof I heare no great commendation, save only for riches . . .”45 Chamberlain questions the aesthetics and cunning of the masque, but not its magnificence.

The most extensive early modern commentary on a masque is that by Orazio Busino, chaplain to the Venetian Embassy who recorded in great detail his experience of attending the 1618 masque, Pleasure Reconciled to Virtue. In his discussion of the performance, he notes the intricacy and beauty of the costumes worn by the masquers. But more interestingly, he mentions the lavish apparel worn by those who are simply attending the event. The Italian and an English translation appear in Orgel and Strong:

... every box was full, especially with most noble and richly dressed ladies, 600 and more in number, according to the general opinion; their clothes of such various styles and colours as to be indescribable; the most delicate plumes on their hats, and in their hands as fans, and on their foreheads strings of jewels, and on their necks and bosoms and in their girdles, and on their garments in such quantity that they appeared so many stars.... The dress worn by these ladies is very beautiful, for those who like it, and for some of them it serves to hide the defects of 
nature, because in the back it hangs almost from the neck to the ground, with long, tight sleeves, and no waist, and without folds; so that any deformity, however monstrous, remains hidden. The farthingale also plays its part. The plump and buxom show their bosoms very openly, and the lean go muffled up to the throat, all of them with men's shoes, or at least with very low slippers. Face masks are as important to them as bread at table, but for these public spectacles they put them aside willingly. ${ }^{46}$

The etiquette of court demands that masque attendees wear the clothes that identify them as belonging among the elite invited to the royal entertainment. It is telling that Busino mentions the fact that the apparel of the era permitted the wearer to control the outline and appearance of her body. One's natural figure likely had some impact on one's physical presentation, but the Italian visitor observed that the dominant fashion allowed "any deformity, however monstrous" to remain hidden. Studies of the masque regularly consider the visibility of the monarch, but only a few mention other spectators, and those primarily focus on the foreign dignitaries who squabbled for place of respect. It must be remembered that the auditorium remained lit during the masque performance, making the king visible from his central location in front of the perspective scenery and the other courtiers visible in relation to his majesty.

For the masques of King Charles and Queen Henrietta Maria, the few early modern written accounts that are available continue to offer praise for the costumes. For the 1632 masque, Tempe Restored, one observer wrote "The queen celebrated the end of the carnival by a sumptuous masque performed with wonderfully rich 
decorations.”47 And for Coelum Britannicum, Sir Henry Herbert wrote “ . . . It was the noblest masque of my time to this day, the best poetrye, best scenes, and the best habitts. The kinge and queene were very well pleasd with my service, and the Queen was pleasd to tell mee before the king, 'Pour les habits, elle n'avoit jamais rien vue de si brave." „48

The Masque of Blackness (1605), Jonson's first venture, was the only one to receive a negative report. In Dudley Carleton's description of the event, he expresses his dissatisfaction with several aspects, including the visual presentation of the masquers:

At the further end was a great Shell in form of a Skallop, wherein were four Seats; on the lowest sat the Queen with my Lady Bedford; on the rest were placed the Ladies Suffolk, Darby, Rich, Effingham, Ann Herbert, Susan Herbert, Elizabeth Howard, Walsingham and Bevil. Their Apparell was rich, but too light and Curtizan-like for such great ones. Instead of Vizzards, their Faces, and Arms up to the Elbows, were painted black, which was Disguise sufficient, for they were hard to be known; but it became them nothing so well as their red and white, and you cannot imagine a more ugly Sight, then a troop of leancheek'd Moors.

Carleton's response does justice to the magnificence of the costumes by noting the richness of the clothes, but he finds the apparel to be "too light" for women of such consequence. His observation makes sense if the portraits of the era are any indication of the clothes that were commonly worn by aristocratic women. The portraits made of 
English women in the first decade of the seventeenth century almost invariably present them with rich, full sets of clothing consisting of several layers. As for women's arms, the fashion for leg-of-mutton sleeves, such as those worn by Queen Elizabeth in portraits from the 1590s, was waning, but many women wore false sleeves over their full sleeves, and none appears with bare arms. The Queen's appearance in public with her arms uncovered to the elbow broke with the fashion of the period and must have seemed shocking to some in attendance.

Furthermore, there is evidence corroborating Carleton's assertion that the costumes were “Curtizan-like.” Perhaps Carleton saw in the Queen’s costume a hint of the "fair hot wench in flame-color'd taffeta" referred to in 1 Henry IV (1.2.10). ${ }^{49}$ Randall Nakayama argues that the apparel of a courtesan was a loose-bodied and flowing gown, noting associations made during the period between the "loose-bodied gown" and the "loose body" of the woman who wears it. ${ }^{50}$ An example of this can be found in The Duchess of Malfi when Bosola is alerted to the Duchess' pregnancy by her “loose gown.” This is telling for, as Orgel has noted, Queen Anna was visibly pregnant at the time of the masque. ${ }^{51}$ The cut of the costume may have been intended simply to accommodate, or perhaps even conceal, changes in her body.

In the text to The Masque of Blackness, Jonson explains that the choice of disguise for the masque was the Queen's own: "because it was her majesty's will to have them blackamores at first, the invention was derived by me” (20-2). Essentially, the Queen told Jonson how she wanted the masquers to appear and Jonson wrote a fiction to realize her majesty's command. Queen Anna's control over the creation of Blackness, and several other masques, challenges the notion that the masques were 
little more than a dramatic panegyric to the rule of the king. Her authority over the entertainment introduces the alternative possibility that they represented and reified the power of the Queen.

The negotiation of political power is at the forefront of analyses of the masque today, for it deals extensively with the power relations at court in a manner that dovetails with New Historical interests. ${ }^{52}$ As Martin Butler notes, it is the court masques that most conspicuously make the intersection of illusions and power available for analysis. ${ }^{53}$ What authority, then, is promoted in a performance that is written to honor the king but carries the shape and presents the individuals chosen by the Queen? Two of the leading voices analyzing the Stuart masque today are in disagreement.

Leeds Barroll identifies the Queen as the primary authority of the early masques of the Stuart reign. She asserted control over all elements of the entertainment and freely disregarded tradition to support her own creative agenda. Barroll identifies this practice starting in 1604 with Twelve Goddesses, the masque that preceded Blackness, which broke a long-standing convention at the English court by presenting not noblemen, but noblewomen. Moreover, these women were not young and eligible for marriage (as was the custom in masques), but rather were married women and members of the peerage. Thus, Queen Anne surrounded herself with a group of powerful women and provided them a venue in which to assert publicly their political significance. Furthermore, these women, by choosing to serve as the primary masquers, assumed responsibility for choosing their dancing partners 
from the various noblemen and dignitaries in attendance, relinquishing the passive role that previously defined the female experience of a masque.

Blackness was a deliberate departure from the norms of the sixteenth-century disguisings and masques, as Leeds Barroll argues: "this calculated ceremony of display was intended to establish the importance of her presence and that of her ladies at the center of a new royal court, the court of the Queen consort.... Twelve Goddesses marked Anna's preemptive move to distinguish her female court from its surrounding patriarchal context. She did this by appropriating the masque itself., Barroll acknowledges the fact that the dialogue spoken in masques uniformly supports the rule of the king, but notes that the spoken part of the event takes up less than a quarter of the total time. The rest is devoted to staging the dancing bodies of the masquers, publicly presenting women who, before this time, would have been relegated to the position of spectator.

The costumes the Queen chose for herself and her fellow dancers furthered her political programs. For Twelve Goddesses, each of the twelve ladies invited to take part in the masque was costumed as a goddess. The Queen chose for herself the personage of Pallas Athene, the goddess of wisdom and defense. Interestingly enough, she did not choose to be Juno, the Queen of the gods, but passed that identity to The Countess of Suffolk. Barrol identifies this choice with the Queen's broad desire to be associated with Athene. ${ }^{55}$ What makes these particular costume decisions important is the fact that, as far as the purpose of a mask is concerned, they were unsuccessful. They did not hide the identity of those in disguise. Or if they did, it was not for long, for the form of the Twelve Goddesses masque mandated that the 
costumed women present themselves in a spatial context that deliberately foregrounded social and political heirarchies. Before Anna asserted her influence over the masque, women took part in organized masques only in private, among themselves, and within doors. ${ }^{56}$ Appearing in the front center of the procession of women, Queen Anna would have been quickly recognized.

In Blackness, Anna was similarly identifiable. Dudley Carleton notes that the black paint covering the women’s faces and arms “was Disguise sufficient, for they were hard to be known,” but only offers that information after providing a full list of the women who took part in the event. If he found the women difficult to identify, he either figured it out in the course of the production or, just as likely, knew who would be dancing before the masque began. The Stuart masque was not a professional performance, but was inextricably connected to the world of the court. Although distinguished by her costume as a foreign and exotic individual, Anna remained the Queen of England when she appeared before her audience. Her public presentation was one she chose for herself and her ladies, and it was one that did not easily locate her under the direct control of English patriarchy.

Steven Orgel disagrees with the notion that the queen was able to assert genuine authority in the masques. Up to a point, he acknowledges the potential subversive power of The Masque of Blackness. Indeed, he goes further and recognizes that “All Jonson’s masques for the Queen imagine her transformed, freed, militantly victorious. ${ }^{, 57}$ Beyond Twelve Goddesses in which the Queen presented herself as a Goddess and The Masque of Blackness in which she appears as a nymph-daughter of the Niger, Anna and her court dressed the part of warrior Queens in The Masque of 
Queens. But Orgel argues that the dialogue of the masque serves to contain the subversive potential of the Queen and locate political authority in the person of the King. Accordingly, the costumes that establish the authority of the Queen in performance serve ultimately to support the preeminence of the monarch that viewed the performance.

Jonson wrote this containment into the discursive portions of the masques he prepared for the Queen. The spoken aspects of the masque, Orgel argues, ultimately served to circumscribe the action taking place in both the anti-masque and the masque and put it in the service of the King. It was for The Masque of Queens, that the antimasque was first introduced. Jonson chose a group of witches to represent the height of evil and chaos and offset the entrance of the main masquers. After the hideous characters perform their dances, the scene suddenly changes as the anti-masque characters are driven from the stage by the mere appearance of the Queen and her masquers:

In the heat of their [the witches'] dance on the sudden was heard a sound of loud music, as if many instruments had made one blast; with which not only the hags themselves but the hell into which they ran quite vanished, and the whole face of the scene altered, scarce suffering the memory of such a thing. But in the place of it appeared a glorious and magnificent building figuring the House of Fame, in the top of which were discovered the twelve masquers sitting upon a throne triumphal erected in form of a pyramid and circled with all store of light. (349-58) 
Anna and her coterie appear in armor, playing the role of valiant warriors. Their might is dramatically realized by the women's ability to banish the anti-masque with their very presence. And Orgel notes "the moment, if we keep the pyramid of triumphant queens with Bel-Anna at its apex in view, is also a genuinely subversive one. ${ }^{58}$ But this authority does not remain with the triumphant queens. Rather it is, itself, displaced by the dialogue that locates power not in the hands of the women and their warlike ideology, but in the authority of the King and in his devotion to peace. The character Heroic Virtue gives credit for the achievements of the Queen:

To that light from whence her truth of spirit

Confesseth all the luster of her merit:

To you, most royal and most happy king,

Of whom Fame's house in every part doth ring

For every virtue, but can give no increase,

Not though her loudest trumpet blaze your peace; (406-10)

Thus, the masque form that provided a space for female presence and authority similarly works to guarantee its containment.

The arguments of Barroll and Orgel are as compelling as they are apparently mutually exclusive. But that mutual exclusivity depends entirely on the notion of a uniform audience response to the masque, and we know that such agreement among those who witnessed the event did not exist. For instance, whereas Carleton found the costumes in The Masque of Blackness disagreeable, another attendee stated that "the masque ... was very beautiful and sumptuous. ${ }^{, 59}$ Rather than attempt to choose between the two positions offered by Barroll and Orgel, it may be more constructive 
to consider them as two possible poles between which individual audience responses can be located.

For the audience members who gave priority to the public presentation of the women, the Queen's masques had the potential to be very transgressive. In the Masque of Queens, the dialogue may attempt to locate the magnificence of the event in the greatness of the King, but the visual codes employed in production suggest something very different. After Heroic Virtue has given his final speech, Fame steps forward and offers the female masquers her chariots. She then orders that the hags be brought forward as captives, bound, and driven before the Queens. The arrangement of the women in the chariots and the captive hags would have been a familiar one to the early modern audience that witnessed the event. It was the arrangement of a heroic triumph, a practice originating in Rome in which conquering kings drove their defeated foes before them in a public spectacle of martial victory. As Sir William Segar explained in 1602, "Triumphs haue bene commonly vsed at the Inauguration and Coronation of Emperors, Kings, and Princes: at their Mariages, Entry of cities, Enterviewes, Progresses and Funerals. ${ }^{\text {60 }}$ When the victorious Tamburlaine drives his enemies before him in the second part of Tamburlaine, it is in the form of a triumph. In the Masque of Queens, the very form of the procession, placing the defeated enemies before their conquerors, establishes a recognizable hierarchy of power. Additionally, the Queens were dressed for a military triumph. Each was costumed in armor as a warrior Queen. Also, some of Jones' drawings of the women show them carrying weapons. Thus appareled, the women are introduced in the speech of the play according to their boldness and conquests: 
Penthesilea, the brave Amazon,

Swift-foot Camilla, queen of Volscia,

Victorious Thomyris of Scythia,

Chaste Artemisia, the Carian dame,

And fair-haired Berenicé, Egypt’s fame,

Hypsicratea, glory of Asia,

Candacè, pride of Ethiopia,

The Britain honour, Voadicea,

The virtuous Palmyrene, Zenobia,

The wise and warlike Goth, Amalasunta,

And bold Valasca of Bohemia ...

The glories of Bel-Anna (391-407).

Portraying women of military prowess and dressed in armor, the masquers assumed roles of considerable influence. Moreover, there was precedent in England for a woman to don armor and take on a position of martial authority. In August 1588 at Tilbury, Queen Elizabeth famously appeared before her troops armed, wearing a silver cuirass, and riding a horse. It seems likely that the masquers in their armor, particularly Bel-Anna, would have stirred up memories of the Queen who had presided over the defeat of the Spanish Armada.

Before the triumphing Queens marched the twelve bound witches whose costumes are identified as symbolic of their particular characters:

My drowsy servant, stupid Ignorance,

Known by thy scaly vesture, and bring on 
Thy fearful sister, wild Suspicion,

Whose eyes do never sleep; let her knit hands

With quick Credulity, that next her stands,

Who hath but one ear, and that always ope;

Two-facèd Falsehood follow in the rope;

And lead on Murmur, with the cheeks deep hung;

She Malice, whetting of her forkèd tongue;

And Malice Impudence, whose forehead's lost;

Let Impudence lead Slander on, to boast

Her oblique look; and to her subtle side,

Thou, black-mouthed Execration, stand applied;

Draw to thee Bitterness, whose pores sweat gall;

She flame-eyed Rage; Rage, Mischief. . . . we faithful opposites

To Fame and Glory. (113-30)

Additionally, Jonson notes, the anti-masque characters wore rats on their head and shoulders, ointment pots at their girdles, spindles, timbrels and rattles. These characters are driven ahead of the Queen in supplication before the dances of the masque are begun. Then, after the dances concluded (over an hour later, Jonson tells us), the triumphant march was repeated and the masquers returned to the house of fame. The spectacle, highlighting Queen Anna and her coterie, served as a strong argument for the significance of those who took part. This is particularly notable since, as Kim Hall has noted, many of the Queen’s chosen masquers were women who resisted patriarchal standards of female decorum in their own lives. For instance, 
among those women was Penelope Rich, who was the mistress of Edward Blount and the mother of four illegitimate children by her first cousin and was sent down from court after the publication of her prose romance (the first by a woman), The Countess of Montgomerie's Urania (1621). ${ }^{61}$ The Masque of Queens established a public forum where the Queen and her chosen circle could present themselves in a particular light before an elite audience.

And yet, the Queen's masques were always undertaken with the approbation and financial support of the King. Accordingly, despite the power of the women's visual presentation, the danger that the masque might have represented to the King's authority did not warrant censure. The one time that the King did step in and decide what could and could not be included in a masque was in 1611. Prince Henry had wanted to conclude his masque with martial games and James vetoed the proposal. ${ }^{62}$ Based on the spoken dialogue that highlights the power of the King and the fact that James never felt it necessary to interfere with the Queen's masques, Orgel concludes that the public entertainments served primarily to support the power of the King.

The issue of where authority should ultimately be located in the Queen's masques can be oversimplified into choosing between the visual and the aural aspects of the performance. What determined the meaning, the spoken words or the visual spectacle? Such a reductive question seeks to circumnavigate the complex nature of the Stuart stage on which both the visual and the aural aspects of the performance asserted meaning. The dialogue, the sets, and the costumes all contributed to a performance that does not readily break down into merely supporting the authority of 
either the King or the Queen. Rather, the Queen’s masques seem to offer convincing arguments for the power and magnificence of both. 


\section{CHAPTER 3}

\section{PLAYWRIGHTS AND PROFESSIONAL COMPANIES}

Throughout the early modern period in England, costumes were essential to the success of the professional playing companies. When Francis Langley prepared the Swan playhouse for use by Lord Pembroke’s Men in 1597, he was required to spend $£ 300$ on new apparel for the players. ${ }^{1}$ Similarly, in order for Worcester’s Men to begin playing at the Fortune in 1602, Philip Henslowe lent them money to purchase fabric and materials and to pay tailors for the construction of costumes. ${ }^{2}$ Furthermore, to protect the important investment that costumes represented, companies often stipulated fines for actors found wearing theatrical apparel outside of the playhouse. The contract with which Robert Dawes joined Henslowe's playing company in 1614 , states that the estimable penalty of $£ 40$ shall be levied if he "shall at any time after the play is ended depart or goe out of the [house] with any [of his] apparell on his body.”3 A troupes’ theatrical apparel represented its single greatest financial investment, surpassing even the cost of scripts and playhouses, and its loss would very likely signal the company’s demise. ${ }^{4}$

Such was the case with Palsgrave's Men (descendants of the Admiral's) when their playhouse, the Fortune, burned in 1621. John Chamberlain noted the event in a 
letter, highlighting the importance of the costumes and the playscripts over the playhouse itself: "On Sunday night here was a great fire at the Fortune in Golding Lane, the fairest playhouse in this town. It was quite burned down in two hours and all their apparel and playbooks lost, whereby those poor companions are quite undone.” ${ }^{5}$ The destruction of a playhouse could be endured. The plays in repertory might be remembered by the actors and performed while new scripts were sought out. The loss of costumes, however, was a terrible blow, and more than anything else threatened to spell the end of a company.

When the Globe burned in 1613, the King's Men quickly rebuilt it and were able to continue playing. This suggests that much of their theatrical apparel was saved or that they were able to quickly reconstitute their inventory. When we consider that the Fortune cost only $£ 520$ to build in 1600 , the $£ 1,400$ required for the new Globe might be explained by the use of some of this money to refurnish burnt costume stores. It is also quite possible that a significant amount of apparel was safe at the Blackfriars. What is certain is that the King's Men were able to provide costumes to continue playing after the outdoor theatre was destroyed. After all, even when the second Globe was torn down in 1642, the King's Men were still able to mount productions again in 1647 (at the end of Parliament's five year ban on playing) because they had kept their costume stores intact. The King’s Men’s were dealt their final blow when their theatrical apparel was taken from them in $1649 .{ }^{6}$ The Kingdom's Weekly Intelligencer reported that soldiers raided several theatres on January 1, 1649. Although some of the troupes were permitted to retain their costumes, the King’s Men caused trouble and had theirs confiscated: 
The players at the Red Bull, who had notice ... were all gone before they came, and tooke away all their acting clothes with them. But at Salisbury Court they were taken on the Stage ... [and] carried to White-Hall with their Players cloathes upon their backs. ... They [the King's Men] made some resistance at the Cockpit in Drury Lane, which was the occasion that they were bereaved of their apperell, and were not so well used as those in Salisbury Court, who were more patient, and therefore at their Releasement they had their cloaths returned to them without the least diminution. ${ }^{7}$

James Wright states in Historia Histrionica (1699) that the soldiers "carried 'em away in their habits, not admitting them to Shift, to Hatton-house then a Prison, where having detain'd them sometime, they Plunder'd them of their Cloths." ${ }^{8}$ Clearly the safeguarding of theatrical apparel was essential to a company's survival.

Scott McMillin and Sally-Beth MacLean identify costumes and the visual aspects of production as the principal elements of the performance style employed by the Queen’s Men in the 1580s. In order to describe this approach to creating drama, they coin the phrase "literalism of the theatre": "theatrical literalism assumes that the real language of showmanship is objective and visual. It consists of the figures and costumes of the actors, the objects they handle, and the properties and structures which frame their acting space.” ${ }^{\prime 9}$ Theatrical literalism accounts for the success of the Queen's Men due to the fact that the troupe was home to a number of extraordinary clowns and employed plays that had a great deal of pantomime. The visual elements 
of production, McMillin and MacLean argue, were thus the centerpiece of the Queen’s Men’s performances.

The importance of costumes to the production of meaning by the Queen's Men can be glimpsed in the complexity of the visual semiotics employed in a short excerpt of the stage directions from Three Lords and Three Ladies of London (c. 1588-90), written by Robert Wilson to be performed by the Queen’s Men:

Enter the three Lords and their pages: First, Policy with his page Wit before him, bearing a shield: the Impresa, a Tortoise, the word, Providens securus. Next Pomp, with his page Wealth bearing his shield, the Word, Gloria sans peer: the impresa, a Lily. Last, Pleasure, his page Will, his impresa, a Falcon, the word, Pour temps: Policy attired in black, Pomp in rich robes, and Pleasure in colours. ${ }^{10}$

In production on the early modern stage, these stage directions served to visually fashion the identities of the characters before they ever uttered a word.

The characters Policy, Pomp, and Pleasure in Three Lords and Three Ladies of London are constructed by their clothes, accoutrements, attendants, and dialogue to represent the city of London, and by extension, England. The various colors, emblems, and names that define the characters show the vitality of the city which is equally devoted to political sagacity, magnificence, and delight. ${ }^{11}$ Moreover, as McMillin and MacLean note, their shields are part of the text of the play: “They speak in emblem and word, they represent the authority of the absent three lords for a 
long stretch of the action, and they form the centre of the contest in the climactic Armada scene, where the three Spanish lords have textual shields too, and the battle is marked out by the advance and retreat of these blazons. ${ }^{\text {21 }}$ In performance before an early modern audience, this visual language did not merely supplement the action of the play; it was the action. And this rich employment of the visual possibilities of production was not unique to the Queen’s Men.

The audiences that viewed the productions of the Queen's Men and other early professional companies were trained to understand the visual codes employed in performance by having seen the very same costume vocabulary and use of symbolism in the pageants, religious plays, and interludes that remained popular well into the reign of Queen Elizabeth. Barbara Mowat has determined that in the sixteenth century, dramatists used costumes for one of two distinct reasons: "either to lead the minds of the audience through the fiction being enacted—the 'game,' as Glynne Wickham calls it—and toward the 'earnest' which lies behind or beyond it; or, conversely, to draw the audience more deeply into the 'game' itself, into the dramatic illusion, into imaginative engagement with the characters and the action., ${ }^{, 13}$ To illustrate the difference between these two aims, Mowat compares the use of costume in John Redford's Wyt and Science to that employed in George Gascoigne’s Supposes.

In Wyt and Science, the costumes ultimately serve a didactic function. The hero, Wyt, casts off his academic gown in order to dance with Honest Recreation. When he falls asleep in the arms of Idleness, he is dressed in a Fool's robe. After he is beaten by Shame, Wyt repents and Reason gives him back his gown. At the end of the 
play, to celebrate Wyte’s betrothal to Knowledge, he receives the "gown of knowledge.” The apparel in the play serves as a key to understanding the moral argument made in dramatic guise. ${ }^{14}$

Gascoigne’s Supposes, Mowat argues, “is designed to teach no moral lesson." ${ }^{15}$ Erastrato begins the play in scholar's robes. When he falls in love with Polynestia, he discards his gown and books to exchange name, habit, clothes, and credit with his servant so that he might be employed by her father and be close to her. This he does, winning Polynesta's love, but he is cast into prison when their relationship is discovered. The happy ending is effected when Erastrato's father appears, identifies his son, and clothes him again in his scholar's attire. Thus dressed in the apparel appropriate to woo Polynesta, Erastrato can enjoy a happy ending. Both Redford and Gascoigne have their protagonist discard their scholar's robes in order to dally with pleasure, but Mowat finds each serving a different function: "in the former, the audience is forced to ask 'what does it mean?' while in the latter, the audience is encouraged to ask 'What will happen next?',16

Mowat's distinction between the symbolic and the illusionistic use of costumes provides a constructive means for understanding the manner in which apparel was employed in the different forms of drama in the sixteenth century. Moreover, she does not find the two functions of costume to have been mutually exclusive at a given point in theatre history or even in a single work. Thus, she finds in 1576, "two different traditions of significant costuming—symbolic costuming and illusionary costuming — both of long standing and both quite alive.”17 Additionally, 
she notes, plays from the 1580s and 1590s increasingly demonstrated elements of both forms of costuming.

There is, however, a significant manner in which both of the plays Mowat considers elicit the same understanding of costume. In Wyt and Science and in Supposes, the audience is keenly aware of the clothes that are appropriate to the protagonist's true identity, i.e., the scholar's robes. The reason that these clothes are appropriate to each character differs, but in both cases, the clothes are closely connected to the inner worth of the one who wears them. In Redford's play, Wyt is connected to his scholar's robes by his moral worth. Accordingly, when he puts off his robes in order to dance, he is understood to be deviating from his true self. Such action is condemned by the moral order of the play which demands that one who steps outside of his or her appropriate place be punished. This is accomplished visually in the fool's robe he is forced to wear and in the abuse he receives from Shame. When Wyt appears again in his proper garb, the audience understands that he is now properly dressed in the clothes appropriate to his true identity. He is then permitted to take on the gown of knowledge at the end because he is understood to have earned it and thus deserves the visual representation of his moral condition. In Gascoigne's play, the grounds of the drama are not moral, but social. Erastrato is of noble birth. Accordingly, in the rigid social world of the play (and the English society before which it was performed), he marks himself as fit for punishment when he dons the servant's apparel that does not accurately signify his noble worth. The happy ending of the play is contrived, but can nevertheless be applauded because it successfully reestablishes the sartorial and social order that was broken by Erastrato's 
disguise. One’s true identity is tightly connected to one’s apparel, and when they are in disagreement, the action of the play works to put them once again in harmony before the conclusion.

In production, the plays whose action was located in the contemporary world, like Gascoigne’s Supposes, employed costumes that adhered to the visual codes governing clothing in early modern England that were discussed in the first chapter. Thus, a servant would have been identifiable on sight as belonging to a lower class than the gentleman whom he served. The plays that employed more symbolic characters, on the other hand, could not rely on the clothing worn in English society for their visual presentation. For instance, there was no clear way that God or the Devil chose to present themselves in public. For characters such as God, Christ, angels, Satan, devils, prophets, abstractions, and even for prodigals and ruffians, a costume tradition developed in the Tudor interludes that established audiences' visual expectations.

It was crucial in Tudor interludes that the meaning of a costume be absolutely clear since the casts were typically small and required that most of the actors play multiple parts. To guarantee that a character's identity would not be mistaken, the costumes associated with particular characters became highly determined. Thus, Fortune would very likely have been identifiable on sight as a woman bearing a wheel or being followed by someone carrying her wheel. Additionally, Fortune might have been depicted with a blindfold since she is often called blind. That stated, Glynne Wickham suggests that the symbolism employed in performance was obvious to the early modern viewer. He writes "Personifications of figurative concepts like the 
Seasons, the Four Elements, the Seven Liberal Sciences, Virtues and Vices, of substantial realities like Cities, Rivers, or of conditions of Peace and War were so commonplace that writers often felt able to dispense with detailed description of their costumes in an otherwise full account of a show.” He mitigates this statement by noting that "on occasion however (perhaps when leisure allowed) very full descriptions are made." ${ }^{\prime 18}$ A review of the extant Tudor interludes demonstrates that the authors nearly always included careful explanations of the characters the actors represented, and quite frequently also provided explications of the particular costumes in which the actors appeared and the properties that they carried. It was rare for a character to appear onstage without being introduced by name or without self identifying himself. For instance, in Three Lords and Three Ladies of London, the three Lords might be understood entirely by the costumes they wear, which are carefully explained in stage directions, but if not, the first lines of the play remove all doubt:

POLLICIE: Here I aduaunce my shield and hang it vp,

To challenge him who euer dare denie,

That one of those three London Ladies rare

Ought not of right be matcht with Pollicie:

A London Lord, the which I represent.

POMP: And pomp prouides his challenge in his word,

(Glorie sauns peere) claiming the one of them,

Not by compulsion, but by common right,

Yet maugre men my shield is here aduaunc'd 
For one matchlesse, a London Lady best

Beseemeth Pompe (a London Lord) to haue.

PLEASURE: Pleasure hath soar'd as dooth his ympreze show,

To look alooffe on earthly Ladies all,

Yet neuer could my curious eie discerne

A Dame of woorth, for Londons Pleasures loue,

But one, and she dooth shine as siluer Dooue.

Of selfe bred soile, of London is her race,

For whom in challenge I my shield aduance. ${ }^{19}$

Clearly the English audiences had a deep appreciation for the use of symbolism in drama, because it is ubiquitous in the interludes of the sixteenth century, the court masques of the seventeenth century, and in the Lord Mayor's shows that extended through both. That stated, the extent to which the symbolism was understood on sight needs to be reconsidered. Indeed, it is primarily because of evidence provided in the play texts that we can piece together how actors were likely dressed in the Tudor interludes and in the plays that followed its tradition of using and reusing a stock set of symbolic characters.

In his book The Tudor Interlude: Stage, Costume, and Acting, T. W. Craik has catalogued the costumes typically worn by characters that appear frequently in Tudor interludes. ${ }^{20}$ His list of characters can be divided into four categories: religious figures, abstractions, representatives of social groups, and Vice. The first category, religious figures, addresses those costumes worn by God, Satan, Angels, devils, damned souls, virtues, sins, and prophets. 
The character of God actually ceases to appear in plays after Henry VIII's reign, but before then, God likely wore rich clerical vestments or the robes of an emperor, bearing an orb and scepter as symbols of power. Satan (or Lucifer, or the Devil), on the other hand, appears in interludes more and more frequently during the sixteenth century, and remains a popular figure on the professional stage until $1642 .^{21}$ He is frequently depicted as being dressed "as deformedly as may be.” Typically, Satan's body is covered in leather skins, in a hairy pelt, or in feathers. Thus, Sir Thomas More writes of "the rugged beare the deuyll.,22 Other important aspects of Satan's apparel include his large and misshapen nose, and the horns that frequently adorn his forehead. For minor devils, scripts often note that the actors appear dressed in "devil’s apparel," but the specifics are unclear. However, the actor would also wear a hideous mask. Damned souls similarly wear ugly masks, and are noted to appear in garments that are painted with flames. Thus, Craik notes, in All for Money (c. 1560) by Thomas Lupton, "Iudas commeth in like a damned soule, in blacke painted with flames of fire, and with a fearfull vizard." ${ }^{23}$ In another instance, instead of having flames painted on, an actor wore a costume made of black and yellow buckram. Angels appeared often in miracle plays, and are noted to have worn a specific coat, wings, and yellow silk hair. In Three Lords and Three Ladies of London, four angles appear bearing bright rapiers to indicate the defeat of the Spanish Armada. This costume was also used to clothe virtues, such as the female Chastity and the male Divine Correction, and Peace, Justice, Verity, and Mercy. The variety of roles for which actors could employ the Angel's costume explains the need to identify 
someone in the dialogue of the play even if the apparel was broadly known to represent a particular character type.

For the virtues and sins, it became common practice in England to dress the former as English ministers and the latter in Catholic vestments. In Catholic countries, this practice was reversed. The complex manner in which the bitter rivalry between Protestants and Catholics found articulation in the religious apparel of the competing churches is addressed in the next chapter. Prophets appeared on stage in a gown and cap of tawny tinsel, a material interwoven with imitation gold or silver thread.

The second part of Craik's study of the costumes in interludes examines those worn by abstractions such as Fortune, Time, Truth, Falsehood, Fame, Labor, Vanity. The typical costume in which Fortune appeared in interludes, as described above, fits the description provided by Fluellen in Henry V: "Fortune is painted blind, with a muffler afore his eyes, to signify to you that Fortune is blind; and she is painted also with a wheel, to signify to you, which is the moral of it, that she is turning, and inconstant, and mutability, and variation; and her foot, look you, is fixed upon a spherical stone, which rolls, and rolls, and rolls” (3.4.30-6) ${ }^{24}$ It is interesting to note that Fluellen's description alternately describes Fortune as a man, “a muffler afore his eyes," and a woman, "and she is painted also with a wheel." The reason Fluellen does this is unclear, though probably he is referring to the male actor who plays a female character. His comment does serve to highlight the fact that while fortune was typically presented on stage as a woman, the character was being played by a boy. 
Fortune is also referred to as two faced and the actor playing her might have worn a mask on the back of his head.

Time appears in only one interlude, but was also seen in Queen Elizabeth’s coronation pageant. His forelock, hourglass, and scythe were likely easily identifiable. Truth, or Verity, as she is presented in Protestant plays, appears as a woman holding an bible in her arms. In David Lyndsay's Ane Satyre of the Thrie Estaitis, the character Veritie is confronted by Flatterie who provides a visual contrast to her by being dressed as a friar. Falsehood or Ill Fame tends to appear as a woman with red spots on her face or garments. Consequently, red spots always denote moral corruption. Fame is typically associated with a gold trumpet, and wore apparel painted with eyes, tongues, and ears. It is possible, Craik suggests, that the practice of covering apparel with symbolic motifs was a common one since the costume worn by Labor is recorded as consisting of "many hands." Vanity wore a costume covered with variously colored feathers to suggest frivolity. Craik does not discuss Justice, but the character shows up often in Lord Mayor's shows and was likely well known and easily identifiable by her scales and sword.

Craik also describes several characters that can be understood easily enough according to the sartorial codes of English society, but grew to be stock characters in Tudor interludes and developed costuming traditions that are worth considering. Since the purpose of many moral interludes was to condemn the extravagance and frivolity of the young "gallant," a specific costume came to be associated with the character. He always appeared in extravagant apparel, and could have been known simply by the feather he typically wore in his hat. It is certain that the prodigal gallant 
would have been dressed very differently from the virtuous rich man who would have appeared in fine apparel, wearing a chain of office, but not in gaudy display. As a variant of the virtuous rich man, the wealthy extortioner was dressed richly and sometimes had bags of money hanging from him to show his desire to hoard wealth.

Vice was the character who most frequently appeared in interludes. And yet, very little is known for certain about the costume he wore. The essence of the character is reckless disreputability, and two aspects of his apparel can be noted. First, he was described by John Heywood as wearing "light array.",25 Second, and much more tellingly, the Vice had a penchant for disguising himself as a virtue. Vice characters frequently don respectable clothes in interludes in order to trick others into following them into sin. Although disguise is frequently used in early modern drama for comic purposes, the history of the Vice characters' dissembling lends a sinister aspect to the practice of changing one's apparel. For instance, Vice's tendency to use disguise in order to pursue his sinful designs lends credibility and a strong precedent to Tamora's decision to present herself and her two sons as the personifications of Revenge, Rapine, and Murder in Titus Andronicus. In Shakespeare’s play, Titus sees through the disguise, but the device itself would have been familiar to the audience as a consequence of the frequency with which Vice characters took on disguises in order to ingratiate themselves to potential victims. The costume tradition of the Tudor interludes guaranteed that those who attended the performances of the early professional companies in London, like the Queen's Men’s performance of Three Lords and Three Ladies of London, would have been familiar with the practice of employing symbolic apparel in drama. 
When the Queen's Men folded in the early 1590s and its preeminence in London was assumed by the Admiral's Men and the Chamberlain’s Men in 1594, playwriting moved away from the interlude tradition. But the theatre remained a place where the visual aspects of performance were vital contributors to the overall meaning produced onstage. A brief look at Marlowe's Tamburlaine suggests the extraordinary importance of the play's visual elements to its overall performance. Indeed, the opening act of Tamburlaine is dependent on the meaning inherent in the apparel worn by the actors, with much of the action of the play proceeding according to the manner in which the characters wear, comment upon, or change their costumes. The play begins with a discussion between Mycetes, the incompetent King of Persia and his attendants. Mycetes is a man "At whose birth-day Cynthia with Saturn joined, and Jove, the Sun, and Mercury denied to shed their influence” (1.1.13-5). ${ }^{26} \mathrm{He}$ is a weak, witless, indecisive king who wears the crown as a consequence of his royal birth, not because of noble worth. And yet his character is not understood as weak in spite of his royal apparel but in juxtaposition with it.

Mycetes' fate is determined by his unworthiness to wear the clothes in which he appears on stage. Decked in the apparel of a king and speaking with the uncertainty of a servant, Mycetes is doomed to fall by virtue of the irreconcilable contradictions he encompasses. Interestingly enough, he appeals to the richness of his clothing as a source of his royal authority, as if the apparel a man wore could alone assert his nobility. When he is openly antagonized by his brother, Mycetes swears upon the greatness of his royal accoutrements that he shall have vengeance:

MYCETES: Well, here I swear by this my royal seat- 
COSROE: You may do well to kiss it then.

MYCETES: —Embossed with silk as best beseems my state,

To be revenged for these contemptuous words. (1.1.97-100)

Assuming his clothes and accoutrements themselves contain royal puissance, the effete king attempts to draw on their authority.

Mycetes' appeal makes sense in light of the sumptuary laws passed in early modern England; they specifically dictated that silk be worn only by the nobility. In 1588, the year Tamburlaine was likely first performed, Queen Elizabeth issued one of her many Royal Proclamations attempting to reassert the long-standing rules determining who could wear what. In that proclamation, she states "no man under the estate of an earl shall wear any cloth of gold or silver, or tinsel, satin, or any other silk." ${ }^{27}$ Although the action of Tamburlaine is set far from England and in the distant past, the play adheres to the visual codes of the time and place in which it was first performed. Moreover, these codes remained viable despite the fact that individuals challenged their authority through noncompliance: although we know of instances when people wore clothes outside their station in the sixteenth and early seventeenth century, the laws governing what was appropriate to particular ranks in society remain stable referents for the period's stages. The opulent fabric Mycetes wears and that which covers his royal seat ought to mirror the royal worth of the man who employs it. By making special note of his silk accoutrement, Mycetes attempts to draw on the authority that ought to accompany one's apparel. Instead, he merely highlights his inability, both figuratively and literally, to fit his station. 
Conversely, Tamburlaine enters upon the stage in the clothes of a shepherd. The specific clothes that would denote him as a shepherd are difficult to determine, but it is likely that he wore simple, loose-fitting, rustic clothes and carried a shepherd's staff with a hook at the top such as those which are nearly ubiquitous in the extant images of shepherds from the period. ${ }^{28}$ Most likely, Tamburlaine’s apparent occupation would have been clear to the audience when his apparel was first seen. And, just as Mycetes would have been understood according to the way his royal apparel contrasted with his diffident demeanor, so would Tamburlaine’s identity have been known according to the way his base clothing failed to match his imperial bearing. He states:

I am a lord, for so my deeds shall prove, And yet a shepherd by my parentage.

But lady [Zenocrate], this fair face and heavenly hue Must grace his bed that conquers Asia And means to be a terror to the world, Measuring the limits of his empery By east and west as Phoebus doth his course.

Lie here, ye weeds that I disdain to wear! This complete armour and this curtle-axe Are adjuncts more beseeming Tamburlaine. (1.2.34-443) Tamburlaine's transformation from shepherd to warrior and from commoner to nobleman occurs visually before the spectators. Despite the power of Marlowe's 
mighty line, the dialogue here serves primarily to add emphasis to an aspect of the action that is intended to be seen and performed, and not merely heard.

When Tamburlaine and Mycetes meet on the field of battle, their contest appropriately centers on an article of clothing, Mycetes' crown. In this encounter, as the action rights what was previously wrong, the importance of costume to the fashioning of identity becomes central: Mycetes was born to the crown but lacks the inner worth that ought to accompany royal ancestry and Tamburlaine was born a shepherd but has imperial merit. Fearful that all of Tamburlaine's soldiers hunt the Persian King, Mycetes attempts to hide his crown so that he will be safe. Only when the battle is over will he risk retrieving it: "For kings are clouts [targets] that every man shoots at, our crown the pin [bull's-eye] that thousands seek to cleave; therefore in policy I think it good to hide it close ... So shall not I be known, or if I be, they cannot take away my crown from me” (2.54.10-4). Mycetes believes that the crown itself holds the authority of the monarch and hopes that he can conceal it for a time and recover it later.

In early modern English drama, crowns do not function as Mycetes thinks they do. They are articles of clothing appropriate only to characters suitable to their worth. Those who are not worthy might wear one for a time, but eventually it will be struck from their head. For example, the title characters in Shakespeare's Richard II and Richard III lose their thrones because they are unworthy to wear the crown. As Alan Downer notes in Richard II, "the visual symbolic exchange of the crown" from Richard II to Bolingbrook "gathers up, focuses and pictorially represents the downfall of a man whose nature was ill-suited to kingship, and who has to some extent come to 
realize the fact.” Richard III is less willing to be parted from his crown, but his unworthiness to wear it similarly guarantees his fall. ${ }^{29}$ Tamburlaine understands the nature of this particular article of apparel. Mycetes, on the other hand, believes the physical crown and his title alone carry the power of his monarchy. Thus, when Tamburlaine threatens him, Mycetes reveals that he is the king and demands the respect that ought to accompany his title and his apparel. Rather than simply take the crown, however, Tamburlaine lets Mycetes keep it until the time is right to simultaneously seize the physical crown and its metonymical extension, the throne of Persia: "Here, take it for a while, I lend it thee, till I may see thee hemmed with armed men. Then shalt thou see me pull it from thy head: thou art no match for mighty Tamburlaine” (2.4.38-41). Mycetes, unaware that crowns cling to those worthy of wearing them, is surprised that Tamburlaine did not simply steal his: " $\mathrm{O}$ gods, is this Tamburlaine the thief? I marvel much he stole it not away” (2.4.42-3). Tamburlaine knows that a crown cannot be kept if it is stolen. Its royal signification demands that the actions by which one obtains the crown are equal to its inherent worth.

As Tamburlaine demonstrates, the apparel worn by actors on stage contributed significantly to the development of the play. Furthermore, it illustrates the manner in which information regarding the costuming of early modern professional playing companies can be determined by piecing together clues provided in the scripts of plays. But there are additional means by which we can determine what was worn in the original performance of Tamburlaine and what it meant to a contemporary audience. For instance, useful information regarding early modern 
performances of Tamburlaine can be found in Henslowe's diary which includes inventories of apparel for the Admiral's Men. There we find an entry for Tamburlaine - a coat with copper lace and crimson velvet breeches (see Appendix A). Also listed are white shepherd's coats and imperial crowns. Copper lace was often used in the theatres to pass for gold lace. It served to visually signify the social class of one who could legally wear such fine apparel (but without costing as much). Similarly, the velvet in Tamburlaine's breeches demonstrated the high rank of the one who wore it. M. Channing Linthicum has noted the extensive use of velvet in the apparel worn by the nobility in England and even by Queen Elizabeth at the time. ${ }^{30}$ In Twelfth Night, when Malvolio dreams of power, he pictures himself in a velvet gown (2.5.48). Early modern audiences would have viewed the shepherd's coats differently. These articles of apparel would not be known primarily by their fabric, but by the profession with which they are identified.

Henslowe's diary is a vital source of information regarding the costumes worn by the Admiral's Men. Its wide ranging lists of apparel and enumeration of exorbitant prices paid for particular items offers one of the most convincing arguments for the centrality of costumes to early modern English theatre. Among the clothes listed are those appropriate to both men and women, a variety of social ranks, and numerous occupations. Here is the inventory written in Edward Alleyn's hand between 1598 and 1602: ${ }^{31}$

1 A scarlett cloke $w^{\text {th }}$ ii brode gould Laces: $\mathrm{w}^{\mathrm{t}}$ gould buttens of the sam downe the sids

2 A black velvett cloke A scarlett cloke Layde [the] downe $\mathrm{w}^{\mathrm{t}}$ silver Lace and silver buttens 4 A short velvett cap clok embroydered $\mathrm{w}^{\mathrm{t}}$ gould and gould spangles 5 A watshod sattins clok $w^{t} v$ gould laces 
6 A pur[l]pell sattin $\mathrm{w}^{\mathrm{t}}$ elted $\mathrm{w}^{\mathrm{t}}$ velvett and silver twist

7 A black tufted cloke

8 A damask cloke garded cloke garded $\mathrm{w}^{\mathrm{t}}$ velvett

A longe blak tafata cloke

A colored bugell for aboye

A scarlett $w^{t}$ buttens of gould fact $w^{t}$ blew velvett

12 A scarlett fact $\mathrm{w}^{\mathrm{t}}$ blak velvett

13 A stamell cloke $\mathrm{w}^{\mathrm{t}}[\mathrm{b}]$ gould lace

14 blak bugell cloke

Gownes

1 hary $\mathrm{y}^{\mathrm{e}}$ viii gowne

2 the blak velvett gowne $\mathrm{w}^{\mathrm{t}}$ wight fure

3 A crimosin Robe strypt $\mathrm{w}^{t}$ gould fact $\mathrm{w}^{\mathrm{t}}$ ermin

4 on of wrought cloth of gould

5 on of red silk ${ }^{t}$ gould buttens

6 a cardinalls gowne

7 wemens gowns

8 i blak velvett embroyde

$9 \mathrm{w}^{\mathrm{t}}$ gould

10 i cloth of gould candish his stuf

11 i blak velvett lact and drawne owt $\mathrm{w}^{\mathrm{t}}$ wight sarsnett

12 A black silk w ${ }^{\mathrm{t}}$ red flush

13 A cloth of silver for pan

14 a yelow silk gowne

15 a red silk gowne

16 angels silk

17 ii blew calico gowns

Antik sutes

1 a cote of crimosen velvett cutt in payns and embryderd in gould

2 i cloth of gould cote $\mathrm{w}^{\mathrm{t}}$ grene bases

3 i cloth of gould coted $\mathrm{w}^{\mathrm{t}}$ oraingtawny bases

4 i cloth of silver cott $\mathrm{w}^{\mathrm{t}}$ blewe silk \& tinsell bases

5 i blew damask cote the more

6 a red velvett hors mans cote

7 A yelow tafata pd

8 cloth of gould horsmans cote

9 cloth of bodkin homans cote

10 orayngtany horsmans cot of cloth lact

11 daniels gowne

12 blew embroyderde bases

13 will somers cote

14 wight embroyd bases

15 gilt lether cot

16 ii hedtirs sett $\mathrm{w}^{\mathrm{t}}$ stons 
Jerkings and dublets

1 A crymosin velvett pd $\mathrm{w}^{\mathrm{t}}$ gould buttens \& Lace

2 a crymasin sattin case lact $\mathrm{w}^{\mathrm{t}}$ gould lace all over

3 A velvett dublett cut diamond lact $\mathrm{w}^{\mathrm{t}}$ gould lace and spang

4 a dublett of blak velvett cut on sillver tinsell

5 A ginger colored dublett

6 i wight sattin cute onwight

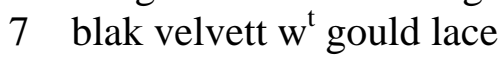

8 green velvett

9 blak tafata cut on blak velvett lacte $\mathrm{w}^{\mathrm{t}}$ bugell

10 blak velvett playne

11 ould wight sattin

12 red velvett for a boye

13 A carnation velvett lact $\mathrm{w}^{\mathrm{t}}$ silver

14 A yelow spangled case

15 red velvett $\mathrm{w}^{\mathrm{t}}$ blew sattin sleves \& case

16 cloth of silver Jerkin

17 faustus Jerkin his clok

frenchose

1 blew velvett embr $\mathrm{w}^{\mathrm{t}}$ gould paynes blew sattin scalin

2 silver paynes lact $\mathrm{w}^{\mathrm{t}}$ carnation satins lact over $\mathrm{w}^{\mathrm{t}}$ silver

3 the guises

4 Rich payns $\mathrm{w}^{\mathrm{t}}$ Long stokins

5 gould payns $\mathrm{w}^{\mathrm{t}}$ blak stript scalings of canis

6 gould payns $\mathrm{w}^{\mathrm{t}}$ velvett scalings

7 gould payns $\mathrm{w}^{\mathrm{t}}$ red strypt scalings

8 black bugell

9 red payns for a boy $\mathrm{w}^{\mathrm{t}}$ yelo scalins

10 pryams hoes

11 spangled hoes

venetians

1 A purple velvett cut in dimonds Lact \& spangels

2 red velved lact $\mathrm{w}^{\mathrm{t}}$ gould spanish

3 a purpell velvet emproydored $w^{t}$ silver cut on tinsel

4 green velvett lact $\mathrm{w}^{\mathrm{t}}$ gould spanish

5 blake velvett

6 cloth of silver

7 gren strypt sattin

8 cloth of gould for a boye

The brevity of the lists provided in Henslowe's diary suggests that they do not

represent a complete inventory of the apparel employed by the Admiral's Men. Neil 
Carson notes that if the lists are taken to be complete and comprehensive, then the company maintained a surprisingly small stock. ${ }^{32}$ Jones and Stallybrass identify gaps in the diary by noting that Henslowe lent money on a number of occasions for costumes that do not appear in their inventory list. ${ }^{33}$ Summarizing the evidence, Andrew Gurr states that "the basic costumes and apparel, hats, jerkins, doublet and hose, seem to have been the players own. There are a few pieces of ordinary daily wear noted in the inventories, but certainly not enough to equip a whole company of players for a performance.”34 The lists in Henslowe's diary provide important insight into the costume stores of a professional company, but do not account for everything that was worn in performance.

The major actors in the Admiral's Men also maintained private costume stores. ${ }^{35}$ Other companies likely also maintained extensive inventories that were supplemented by the collections of principal actors. Looking principally at the King's Men, Jean MacIntyre argues that the doubling requirements of later plays demanded more costumes and a larger variety than earlier ones, suggesting that inventories grew over time as costumes accumulated. ${ }^{36}$ This makes sense because clothes were rarely thrown away. Even when articles became worn, they were typically either mended or translated (used to make different pieces of apparel).

In the early days of the professional companies, when troupes performed at court, their costume stores were often supplemented by the holdings of the Office of the Revels. For instance, for the play Phillyda and Choryn (now lost) presented by the Queen's Men on 26 December 1584, a number of items were provided: 
A pastorall of phillyda \& Choryn presented and enacted before her maiestie by her highnes servauntes on $S^{t}$ Stephens daie at night at Gerenewich whereon was ymployed [unlisted number] yardes of Buffyn for Shepherdes coates $x x x^{\text {tie }}$ ells of sarcenet for fower matachyne sutes one greate curteyne and scarfes for the nymphes one mountayne and one great cloth of canvas and vj peeces of buccram. ${ }^{37}$ The court's practice of providing costume materials for professional playing companies ceased in the early 1580s when the troupes developed sufficient collections to support their performances without assistance. ${ }^{38}$ This growth in costume stores coincides with the building of playhouses in London and likely increased with the expanded purchase of new scripts by the professional companies in the 1590 s. ${ }^{39}$ Costumes, playhouses, and scripts all seem to have similarly benefited from the burgeoning business of theatre at the end of the sixteenth century.

Although no lists of costumes and properties are extant for the other public theatres and companies, it is still often possible to reconstruct aspects of what was worn and how that apparel was employed in production. For example, in Hamlet, costume served a crucial role in the establishment of meaning on stage. Hamlet enters the play wearing the black clothes of mourning. This choice is commented upon by the Queen and clarified by Hamlet himself:

'Tis not alone my inky cloak, good mother, Nor customary suits of solemn black, Nor windy suspiration of forc'd breath, No, nor the fruitful river in the eye, 
Nor the dejected havior of the visage,

Together with all forms, modes, shapes of grief,

That can denote me truly. These indeed seem,

For they are actions that a man might play,

But I have that within which passes show,

These but the trappings and the suits of woe. (1.2.77-86)

Hamlet's explanation for his chosen apparel and appearance is clear: he grieves for the loss of his father, the king, and literally embodies his sentiment. What remains unclear in the text of the play, but would have been conspicuous in performance on the early modern stage, is how Hamlet's costume on stage differs from those worn by the other actors. Claudius suggests that the court is simultaneously in a state of mourning for the death of king Hamlet and in a state of celebration for his marriage to Gertrude:

With an auspicious, and a dropping eye,

With mirth in funeral, and with dirge in marriage,

In equal scale weighing delight and dole, (1.2.11-4)

And yet, as G. K. Hunter has noted, there can be no balanced attitude in one's choice of apparel. Claudius speaks of being equally happy and sad, but his clothes threaten to contradict his words. Hunter states "the economy of the scene as well as the economics of the theatre make it likely that the clothes of Claudius, Gertrude and the rest of the court express the 'auspicious' ... 'mirth' ... 'delight' side of the marriage/funeral dilemma. ${ }^{40}$ This contradiction between what is seen and what is heard provides the first example of Claudius' mendacity. 
Further in Hamlet, costumes serve as the outward sign of inner infirmity both in Hamlet's feigned madness and Ophelia's genuine madness. Although it may be Hamlet's “antic disposition” that convinces Ophelia he is mad, her description of his condition begins with a discussion of his clothes:

Lord Hamlet, with his doublet all unbrac'd,

No hat upon his head, his stockins fouled,

Ungart'red, and down-gyved to his ankle,

Pale as his shirt,

A gentleman and a nobleman would never willingly present himself with his doublet open, with no hat on his head, with his stockings dirty and hanging at his ankle, and without garters. Hamlet must be mad. After he has been thus described, Hamlet next enters with his apparel in this disordered condition. This explains the Queen's first comment when she sees him: "look where sadly the poor wretch comes reading" (2.3.168). Of course, the audience has been prepared for Hamlet’s feigned insanity and is in on his trick. This is not the case when Ophelia enters in 4.5 distracted, with her hair down and playing on a lute. The visual signs of her madness prompt Laertes to lament her infirmity when he first sees her, before she ever speaks a line.

Costume similarly figures importantly in Macbeth. As Cleanth Brooks has noted, it is Macbeth's decision to wear clothes that sit upon him like poorly fitting garments that marks his improper assumption of rank in the play. Brooks writes “these are not his garments; in Macbeth’s case they are actually stolen garments. Macbeth is uncomfortable in them because he is continually conscious of the fact that they do not belong to him. ${ }^{41}$ A principal proponent of New Criticism, Brooks is 
primarily interested in the metaphor of apparel, but on the early modern stage, Macbeth's clothes would have served as a visible indication of his original social status and then his assumed rank. By taking the crown and royal apparel when he has only recently donned the clothes of the Thane of Cowdor, Macbeth shows himself to be costumed inappropriately. Cathness notes Macbeth’s attempt to wear clothes that are beyond the scope of his mandate, saying "He cannot buckle his distemper'd cause within the belt of rule.” Angus similarly states "Now does he feel his title hang loose about him, like a giant's robe upon a dwarfish thief” (5.2.15-22). Macbeth’s attempt to dress outside his station is contained by the conventions of tragedy which makes him pay for his transgression with his life.

Contradictions between the words one speaks and the apparel one wears are of course common in comedies where they occur most frequently in the form of disguises. This comic trope appears so frequently in early modern drama that simply listing plays that use it would grow tedious. In consciously putting on a disguise, a character lets the audience in on the secret that he or she is pretending to be someone else. At the heart of this device is the notion that the character has a genuine identity, tightly tied to a particular set of apparel, to which that character will return when the purpose for using the disguise has been fulfilled. It is in the return to one's true apparel that disguises are made the proper material of comedy. The comic practice of using a disguise frames potentially subversive behavior by carrying a tacit promise of a return to acceptable norms before the play has concluded. Thus, it is comical to see Rosalind put on masculine attire and pretend to be Ganymede in As You Like It because the audience knows that before the action is concluded, she will resume her 
proper, female attire. In this manner, the possibility that one might be able to change his or her identity simply by altering apparel is contained within the liminal space of comedy.

Such is the case with Roland Lacy in Dekker's The Shoemaker's Holiday. He is defined in the play as a courtier, one "who will in silks and gay apparel spend more in one year” than a Lord Mayor can afford. To exceed the resources of a Lord Mayor, the cost of one's apparel must be truly extraordinary. The exorbitant cost of Lacy's clothes is suggested by Sybil's description of them. She first notes that she could barely identify him, suggesting that his clothes were new: "I scant knew him - here 'a wore a scarf, and here a scarf, here a bunch of feathers, and here precious stones and jewels, and a pair of garters - O monstrous! - like one of our yellow silk curtains at home” (2.25-8). ${ }^{42}$ The general apparel, both new and expensive, makes clear his high place in society while his yellow garters suggest he is in love. At the opening of the play, Lacy's uncle, the Earl of Lincoln, speaks with Roger Oatley, the Lord Mayor to warn him that Lacy is in love with his daughter Rose. Both agree that a marriage between their children would be unsuitable and work to guarantee that it never takes place. Lincoln has Lacy commissioned as an officer for the wars in France and Oatley moves Rose to a lodging outside of London.

To foil the efforts to separate him from his love, Lacy forsakes his military service and his fine clothes, and disguises himself as a Dutch shoemaker: "I trust Fortune and this disguise will further me once more to view her beauty, gain her sight” (3.16-18). Appearing before the shop of Simon Eyre, Lacy is believed by the workers there to be a shoemaker because of the equipment he bears, even though the 
accent he assumes makes him nearly unintelligible. Firk says “for my life, yonder's a brother of the Gentle Craft [shoe making]. If he bear not Saint Hugh’s bones, I’ll forfeit my bones. He’s some uplandish workman” (4.4.45-6). To make his costume complete, Lacy no doubt replaced his scarves, feathers, and jewels with plainer clothes and an apron. The foreign identity Lacy also assumes makes his character more comic without interfering with the primary purpose of the disguise, i.e., to provide a means to see Rose. This he accomplishes by visiting her for the purpose of fitting her with a new pair of shoes, and the two make plans to elope. Their plot then reaches its happy conclusion when Lacy is once again in his proper clothes and his marriage to Rose is legitimized by the King himself. Thus, during the course of the comedy, Lacy takes on the identity of a shoemaker by donning the clothes and accoutrements that specifically mark the profession, but the happy ending is always understood to be marked by his resumption of his true identity which is visually marked by his noble apparel.

The happy conclusion we see for the newly married Jane and Ralph is similarly contingent on the notion that one's apparel must be in accordance with one’s true identity. After Ralph has been sent to the wars in France, Jane is courted by the wealthy Hammon. When he tells her that Ralph has been slain, she reluctantly agrees to marry him. Moments before their wedding, however, Ralph presents himself before Jane. The clothes she wears in this scene are gifts from Hammon and, like livery, reflect her newfound connection to the wealthier man. But she is already married to Ralph; her clothes do not represent her true identity which, in a comedy, 
requires that a wife be indelibly connected to her husband. Accordingly, when Jane makes her choice between the two men, her language is sartorial in nature:

Whom should I choose? Whom should my thoughts affect

But him whom heaven hath made to be my love?

[To Ralph] Thou art my husband, and these humble weeds

Makes thee more beautiful than all his wealth.

Therefore I will put off his attire,

Returning it into the owner's hand,

And after ever be thy constant wife. (18.56-62)

She refuses the fine clothes that are alien to who she is in the eyes of God and according to the conventions of comedy, and embraces the shabbily dressed man that is her true love.

The framing power of comedy assumes a pronounced significance when the altering of apparel consists of a woman dressing as a man. It must be remembered that the actual practice of cross dressing was a source of genuine anxiety in early modern England. John Chamberlain records King James’ desire that the clergy “inveigh vehemently and bitterly in their sermons against the insolency of our women, and their wearing of broad-brimmed hats, pointed doublets, their hair cut short or shorn, and some of them stillettos or poniards . . . adding withall that if pulpit admonitions will not reform them he would proceed by another course.”43 James wanted the visual signs denoting sex to be clearly identifiable in one’s apparel.

Far from issuing a threat to that system, the early modern public stages actually supported the rules governing the proper appareling of the body. ${ }^{44}$ By having 
female characters dress as men but return to their female garb before the close of the action, the plays promised that the "woman's weeds" were the genuine signifiers of a woman's identity. The clothes are of the essence, particularly since all of the women would have been played by boys. Thus, once a boy is understood to be a woman, he maintains that feminine identity for the duration of the play, regardless of crossdressing.

Stephen Greenblatt has noted that the threat of a woman actually transforming into a man and vice versa appears in early modern documents. ${ }^{45}$ However, there are no recorded instances of this occurring in an early modern English play. Nor are there instances of a play, whether a comedy, tragedy, or romance, concluding with a man married to a man or a woman to a woman. Accordingly, when Greenblatt muses over the anxiety that might have been aroused by the possibility in Twelfth Night of Olivia marrying a woman, he does not give due credit to the power of comedy to contain precisely this fear. Many have noted, and it must be conceded that this particular drama ends with a woman, Viola, wearing masculine attire. But the final lines in the play make it clear that feminine attire constitutes the essence of Viola's identity and her future happiness: "Cesario, come - For so you shall be while you are a man; But when in other habits you are seen, Orsino's mistress, and his fancy's queen” (5.1.3878). While dressed as a man, the character is Cesario, but when the character appears in the apparel of a woman, she will be Viola and the happy ending will be realized.

In Ben Jonson's Epicoene, we have an instance of the danger that Greenblatt highlights, a man marrying a boy. The wealthy gentleman Morose is tricked by his nephew Dauphine Eugenie into marrying Epicoene, a boy dressed as a girl. However, 
even here, the possible arousing of anxiety remains controlled because the marriage does not take place at the end of the drama, but in the middle. The liminal safety of comedy guarantees that after the play's conclusion, men can only be married to women. As Northrop Frye notes, "comedy usually moves toward a happy ending, and the normal response of the audience to a happy ending is 'this should be,' which sounds like a moral judgement. So it is, except that it is not moral in the restricted sense, but social." ${ }^{46}$ Accordingly, before the play concludes, Epicoene’s true sex is revealed by the removing of his peruke, and Morose's marriage is rendered invalid because the law simply prohibits such couplings.

Indeed, rather than challenge the sexual norms or costuming conventions in early modern England, Epicoene seems actually to reify them. To begin with, the play was originally performed by a children's troupe, the Children of Her Majesty's Revels. ${ }^{47}$ The children's companies differed from the adult companies in that the former needed to use costumes to construct the sexual identities of both its men and its women. As was noted in the first chapter, for a boy to play either an adult male or female, he would have to put on the particular apparel denoting that sexual identity. Whether it be a bodice, farthingale, and skirt, or a doublet, breeches, and beard, the clothes a boy put on constituted his character's sex on the stage.

The stability of the sartorial signifiers of one's sex are then enhanced by the play which severely punishes women who act unfeminine and men who fail to act masculine. For instances, the Collegiates are described as women "that live away from their husbands and give entertainment to all the Wits and Braveries o' the time, as they call 'em, or cry down or up what they like or dislike in a brain or a fashion 
with most masculine or hermaphroditical authority” (1.1.72-77). ${ }^{48}$ Karen Newman notes the early modern aversion to garrulous women: "talking women are not merely the butts of satire, but are represented as monstrously unnatural because they threaten masculine authority." ${ }^{49}$ When it is revealed that Dauphine’s minion Epicoene has infiltrated their inner circle and gleaned their secrets, the Collegiates realize they are beaten and are silent for the first time. In this manner, the play simultaneously suggests how a woman is supposed to appear and how she is supposed to act. Similarly, Daw and LaFoole are effeminate men whose cowardly actions belie the masculine clothes they wear. Like the Collegiates, they are punished for breaking the expectations that accompany their apparel. In this manner, Jonson's play toys with the manner in which clothes denote one’s identity, but ultimately reaffirms the extant visual codes.

Although productions of early modern plays can be performed today with few or no distinguishing costumes, this was not the case in the late sixteenth and early seventeenth centuries. At that time, one's apparel played a crucial role in fashioning a person's identity; clothes did not merely reflect one’s sex, class, profession, and more, but actually served to produce it. Moreover, the apparel that was worn in production took part in and served to continue a costuming tradition that traced back to Tudor interludes and persisted until the closing of the theatres in 1642. The concept of "neutral” clothing did not exist: choice of fabric would immediately suggest one’s social station, choice of garments would suggest one's profession, choice of color would suggest livery and allegiance, choice of accoutrements would suggest even more. Accordingly, actors did not walk onto the Shakespearean stage as blank slates 
that could be inscribed with a playwright's words. Their costumes located their place in the drama and defined their role before they ever uttered a line. 


\section{CHAPTER 4}

\section{MIDDLETON'S A GAME AT CHESS}

This chapter will consider a single performance in far greater depth in an attempt to understand, as fully as possible, how costume functioned in a specific place and at a particular moment in early modern English theatre history. The play that will be examined here is the production of Thomas Middleton's A Game at Chess that was acted by the King's Men for a record nine consecutive performances at the Globe playhouse between August 5 and 14 (except for Sunday) in 1624. The primary reason this play will be examined is, as R. C. Bald noted, "more is known about $A$ Game at Chesse [sic] than about any other pre-Restoration play."1

Although there is little evidence by which we can be certain, it appears that more effort was put into costuming A Game at Chess than was typical at the time. It was not uncommon for theatre companies to purchase specific articles of apparel when preparing to stage a new play. For instance, Henslowe's diary shows that when the Admiral’s Men staged the first part of Cardinal Wolsey, Henslowe paid $£ 35$ for costumes and properties, and another $£ 11$. 6s. for costumes for the second part. $^{2}$ Even though there are no extant property lists for A Game at Chess, the specific costume and property demands of the production suggest that special effort was made for it. 
Despite the absence of an inventory of the apparel used in the production, there is a great deal of alternative historical evidence which lends itself to a study of the production's costuming. In addition to several different texts of the play, together providing considerable insight into its original composition, ${ }^{3}$ there is also contemporary commentary that speaks to the particulars of the production.

The most promising place to look for information regarding the costumes worn in the original production would appear to be the title-page of the First Quarto. Divided into two parts, the title-page presents a considerable amount of information. The top half shows a table with the left side labeled "The Black-House" and the right side “The White-House.” On the one side we find the Black King, the Black Queen, the Black Duke, and the Fat Bishop. Across from them sit the White King, the White Queen, the White Duke, and the White Bishop. The bottom half of the title-page shows three characters: the Black Knight, the White Knight, and, again, the Fat Bishop. Also, there are three miniature characters which appear in a bag in the back, meant to represent the chess bag which holds all of the pieces which are taken in the game. 


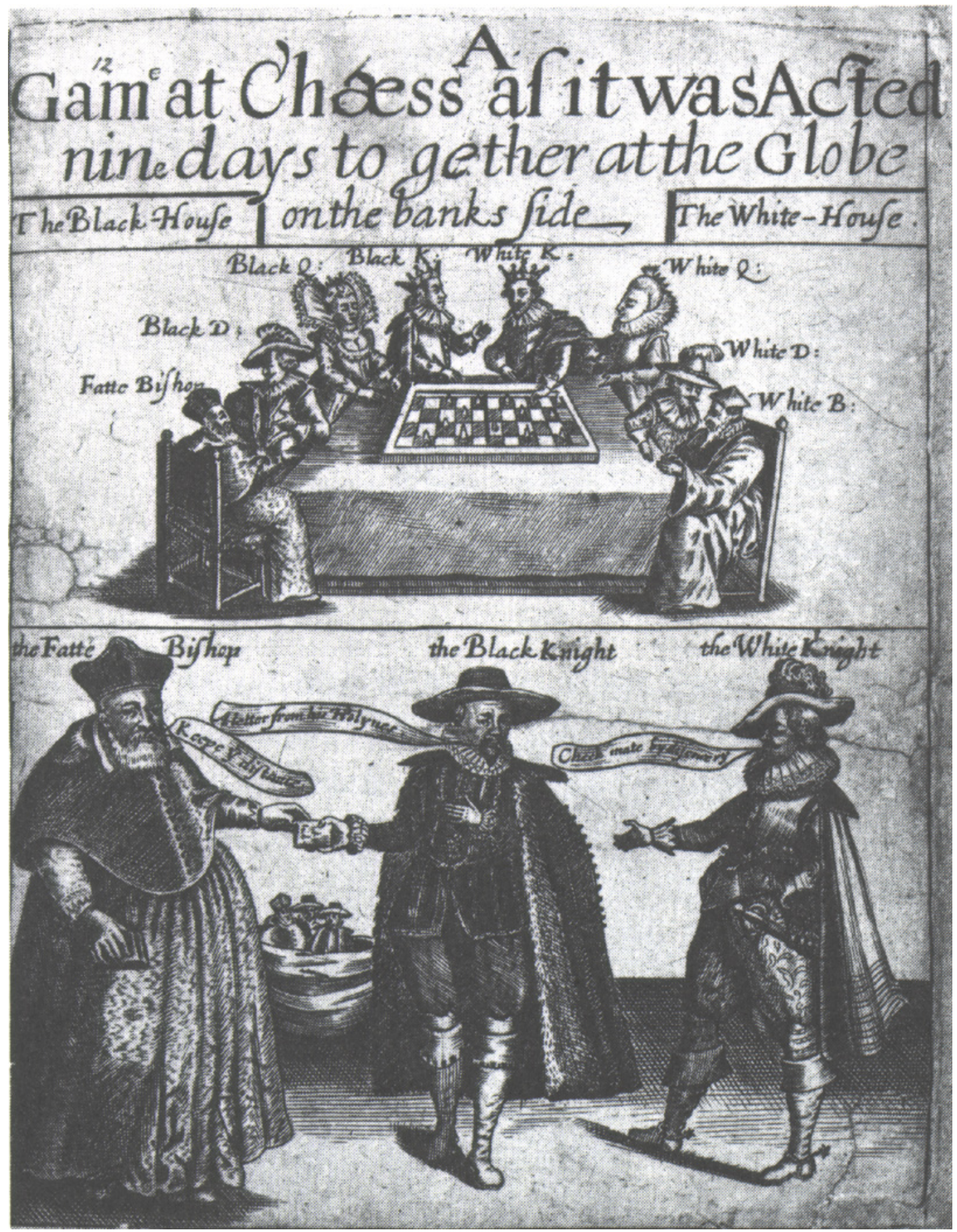

Image 12. Title-page of A Game at Chess, Q1. ${ }^{4}$ 
The costumes presented on the page are clearly drawn and the particular articles of apparel easily distinguishable. However, this information is potentially misleading, for the pictures are drawn in the likeness of the historical figures they were intended to represent and not in the form of the players who performed the roles. A Game at Chess was a topical contemporary play in which many, if not all of the characters were intended to represent real individuals, most of them political or religious figures from England or Spain. Thus, John Moore notes that the White Bishop on the title-page looks distinctly like George Abbot, the Archbishop of Canterbury; the Black Duke resembles the Conde-Duque Olivares in the cut of his beard and the heavy outlines of his body; the White Duke has the strikingly triangular beard of George Villiers, the Duke of Buckingham; and the White Knight has the "same face, with the delicate profile and the large mournful eyes, which Van Dyke immortalized in portraits of [Prince] Charles. ${ }^{.5}$ Indeed, in the case of the Black Knight and the Fat Bishop, scholars have gone beyond identifying the characters as representing Count Gondomar and Marc Antonio De Dominis and determined the actual portraits of those men which were most likely used by the artist who made the title-page. ${ }^{6}$

It is clear that the information provided by the title-page needs to be considered in a particular light. Obviously it does not represent how the characters actually appeared on stage, but it does suggest how they were understood by the people who first bought the quarto and read the play. For those who did not attend the performance but read the published quarto, the characters would be understood, from 
the beginning, to represent well known political figures. To determine what was actually worn on stage, however, additional sources of evidence must be consulted.

Contemporary commentary provides some of the most significant sources for determining what was worn in performance and how it was seen by the audience in attendance. Among the extant letters from the period that mention A Game at Chess, several note that the characters on stage were intended to represent well known contemporaries from England and Spain, including royalty which was expressly forbidden. John Holles (c. 1565-1637), then Baron Haughton, later first Earl of Clare, saw the play on August 10 and wrote to Robert Carr, Earl of Somerset, about the experience, ${ }^{7}$ noting that the play provided "a representation of all our spannishe traffike.”8 The Spanish traffic Holles mentions refers to the intense anti-Spanish feelings that were a constant in England since before the defeat of the Armada in 1588 and had grown to a fevered pitch in England in 1624. In October of the preceding year, Prince Charles and the Duke of Buckingham returned from Spain following a failed attempt to draw up a marriage contract between Charles and the Spanish Infanta. Charles' trip had been a source of profound anxiety throughout England, because the possible marriage threatened both the life of the heir to the throne by putting him in the hands of the Spanish and the religious future of the Protestant nation by allying it through marriage to a powerful and avowedly Catholic country. So great was the fear caused by Charles' trip, that his return, without a Catholic wife, elicited jubilation throughout England. Bonfires were lit, candles burned in windows, churches sang out in praise of the return of the Prince, and the 
long-standing restraints against the expression of anti-Spanish and anti-Catholic viewpoints was relaxed. ${ }^{9}$

It is in light of these events that Holles and the rest of the English audience first saw A Game at Chess. ${ }^{10}$ The foreign relations between Spain and England inform both the substance of the play and the manner in which it was received; Holles summarizes the play, saying the "descant was built uppon the popular opinion, that the Iesuits mark is to bring all the christian world vnder Rome for the spirituality, \& vnder Spayn for the temporalty." ${ }^{\text {11 }}$ To a study of the use of costume in the play, Holles commentary is significant because it indicates that he saw the apparel worn on stage as serving overwhelmingly to make the wearers distinguishable as particular players in national policy, and not merely as players on a stage. Accordingly, although Holles notes that "the whole play is a chess board, England the whyt hows, Spayn the black,” and he refers briefly to black and white pieces, he primarily discusses the characters by using the names of the people they represent. He mentions “Gundomar,” Count Gondomar - Don Diego Sarmiento de Acuna, the Spanish ambassador to England 1613-18 and 1620-22; “Ignatius Loyala," the founder of the Society of Jesus, the Jesuits, in the sixteenth century; “Bristow,” John Digby, Earl of Bristol, who was a long time ambassador to Spain, but was under house arrest at the time of the production under suspicion of supporting the Spanish cause; "Spalato," Marc Antonio de Dominis, Archbishop of Spalatro, who converted to Protestantism and was openly received by James in England but left the country and converted back to Catholicism in 1622. 
Other detailed reports of the play are not first hand, but nevertheless provide insight into what was seen on the stage. Don Carlos de Coloma, the Spanish Ambassador Extraordinary, writing to the Conde-Duque Olivares, favorite of the Spanish King, on 20 August 1624, notes that the characters on the stage are clearly meant to represent actual individuals. In addition to mentioning St. Ignatius, the Archbishop of Spalato, and the Count of Gondomar, he states that "the king of the blacks has easily been taken for our lord the King, because of his youth, dress, and other details." ${ }^{\text {12 }}$ Sir Edward Conway, Secretary of State wrote to the Privy Council on 12 August 1624 that King James received word from the Spanish Ambassador that a comedy was being performed wherein "they [the King's Men] take the boldnes, and presumption in a rude, and dishonorable fashion to represent on the Stage the persons of his Maiestie, the Kinge of Spaine, the Conde de Gondomar, the Bishop of Spalato, \&c." ${ }^{13}$ Contemporary report makes it clear that many of the actors on stage were immediately identifiable by virtue of the costumes they wore. To the list of people mentioned in the correspondences from the period, we can add the White King, the White Knight, and the White Duke who, from their roles in the play, would have no doubt been easily recognizable as King James, Prince Charles, and the Duke of Buckingham.

But the written responses to A Game at Chess do more than just indicate whom the costumes helped the actors impersonate. They also suggest how the apparel they wore worked to fashion their character on the stage. And costume is here intended to mean the visual signals provided on stage including clothing, makeup, hair, and accoutrements, elements that are essential to production. Consider 
Gondomar. The contemporary report makes it clear that the actor playing him was immediately recognizable onstage. Indeed, John Chamberlain notes in his commentary on the play that the actors had gone so far as to purchase one of the Ambassador's old suits, or clothing made to resemble it: "they counterfeited his person to the life, with all his graces and faces, and had gotten (they say) a cast sute of his apparell for the purpose.”14 Beyond observing that Gondomar was readily identifiable, however, several contemporaries note that he appeared on the stage with his well known litter and chair. The litter was one that he frequented while in London and the chair was specially designed with a hole in the bottom to accommodate his severe case of anal fistula. In the same sentence in which John Holles mentions Gondomar, he notes the fact that the character appeared on stage in his litter, "his open chayre for the ease of that fistulated part." ${ }^{, 15}$ Don Carlos de Coloma says that Gondomar was "brought on to the stage in his little litter almost to the life, and seated on his chair with a hole in it." ${ }^{~}$ Writing to Sir Dudley Carleton, Sir Francis Nethersole only briefly mentions A Game at Chess, but makes sure to note the chair: “Gondomar brought on the Stage in his chayre.” Count Gondomer’s particular bodily infirmity, then, was an integral part of his visible personation on the stage. A picture of Gondomar's litter and chair appear on the Title-page of Thomas Scott's Vox Populi, which was published in 1624 and served as a major source for Middleton's play. ${ }^{17}$ 


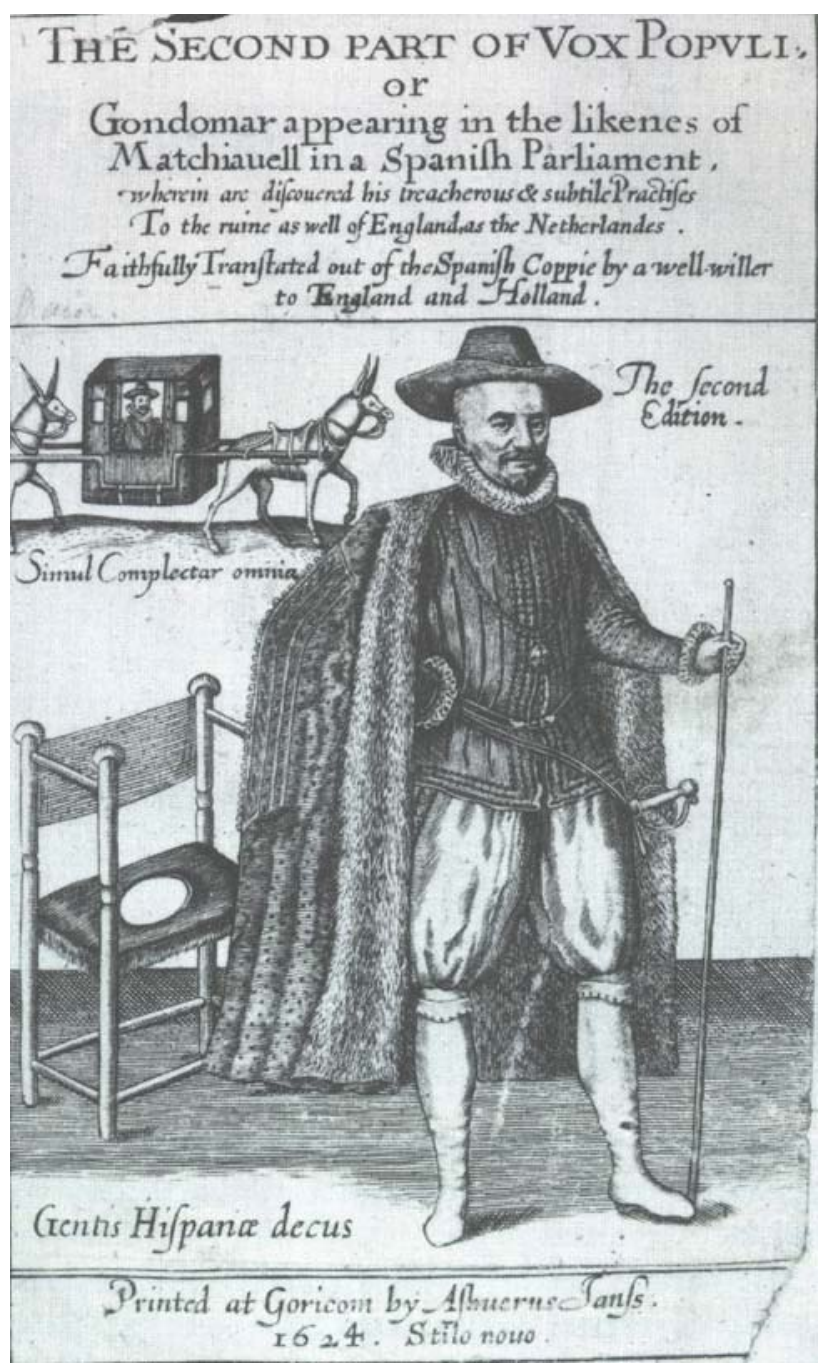

Image 13. Title-page of Scott's Second Part of Vox Populi. ${ }^{18}$

What makes Gondomar's ailment particularly important to the play is the timing with which the litter and chair are introduced - Act 5 . There can be little doubt, however, that the actor playing the Black Knight would have been identified as Gondomar long before the fifth act. Gondomar’s alleged villainies, Howard-Hill notes, were common gossip in London before A Game at Chess was performed.${ }^{19}$ His particular physical malady was equally well known. And to make certain his audience is aware of the Black Knight's defining physical characteristic, Middleton has the Fat 
Bishop state "Yonder's Black Knight, the fistula of Europe”20 at 2.2.46, long before the audience would have seen the visible representation of the Black Knight's ailment. The early modern association of physical flaw and moral infirmity, such as we see in Shakespeare’s Richard III and Middleton’s De Flores from The Changeling, informs the manner in which the Black Knight would be understood; the appearance of his specially prepared chair late in the play provides a visually operative comic stab at a character who has shown himself enormously worthy of abuse through his “20,985” schemes and machinations.

The Black Knight is not the only character whose identity is fashioned or commented upon by the visual signs that were presented on the stage. The visible contrast posited by the play between the Black Queen and the White Queen deserves consideration. There is little evidence either in the text or in contemporary commentary suggesting how either appeared in performance. That stated, the titlepage presents them in very different apparel and deserves note. Moore has addressed the appearance of the two queens, writing:

The middle-aged White Queen, with the high forehead and prominently beaked nose of Anne, wearing the pleated ruff and highcut bodice of an earlier style of dress, is sharply contrasted with the young Black Queen, with her more delicate features, wearing the fanshaped ruff and the low square-cut bodice of the new style which had spread from France, the native home of Isabella of Bourbon. ${ }^{21}$

What Moore fails to note is that the style of dress worn by the Black Queen with its ample décolletage was most commonly worn in England by unmarried women.$^{22}$ 
And, since this style was not commonly seen in Spain, it seems that the style was specifically chosen to represent the Black Queen. Consequently, the Black Queen’s apparel insinuates sexual accessibility in one who should be unavailable, and visibly mirrors her pawn's sexual forwardness with the Black Bishops Pawn in 4.3. That stated, it must be reemphasized that the physical representation of the Black Queen in performance remains a point of conjecture.

More informed conclusions can be made regarding the costumes worn by the characters representing the clergy of the White House and Black House . The play has six characters who are members of the clergy: the Black Bishop, the Black Bishop's Pawn, the White Bishop, the White Bishop’s pawn, Loyola Ignatius, and the Fat Bishop. ${ }^{23}$ The costumes they wore in performance can be inferred from the rigid rules that defined appropriate clerical garb in Protestant England and Catholic Spain. Accordingly, the White Bishop and his pawn can be understood to have worn academic robes and a square cap, and the Black Bishop and his pawn can be understood to have worn Catholic vestments (Loyola Ignatius and the Fat Bishop will be dealt with later). The importance of the costuming choices employed for the clergy of the Black and White houses cannot be overestimated for the clothes worn by Protestants and Catholics served to literally embody the religious ideologies of each.

The vestments worn by the Black Bishop and his pawn are vital to their roles as members of the Catholic church, for the religious attire serves to visibly represent a priest's vow of sexual abstinence, thereby separating him from the rest of society. Essentially, the apparel works to identify the clergy as intermediaries between God and man. The costumes worn by the two are identified as Catholic vestments in the 
White Queen’s Pawn’s exclamation upon first seeing the Black Bishop’s Pawn: “By my penitence / a comely presentation, and the habit, to admiration reverend” (1.1.345). The Black Knight notes the specific articles that adorn the Black Bishop’s Pawn, saying that perhaps he should wear "a three pound smock 'stead of an alb, / An epicene chasuble” (1.1.231-2). The alb and the chasuble are part of the Catholic vestments. The alb is a white linen, shirt-like garment that reaches nearly to the ground and is secured at the waist by a girdle. A chasuble is the principal Mass vestment, worn over the rest. It is a square or circular piece of cloth that has a hole in the middle for the head.

Vestments visually assert the fact that, in the Catholic church, the clergy served a mystical function essential to the salvation of the congregation. Christopher Haigh provides a précis of the religious life of early modern Catholics, noting that there were modes of Christian living to accommodate various levels of devotion, yet noting the essential role of the clergy to them all.

There was scope for mysticism and contemplation in the religious orders, as best exemplified by the Carthusians. There were patterns of ascetic life available for the fervent who were unable to withdraw from the secular world . . . Laymen (laywomen somewhat less easily) could join religious guilds, read pious books, give alms to the poor and sick, pray through favourite saints, and attend mass frequently to savour the mystery of bread become God ... For the religious minimalists, there was an undemanding scheme of salvation which rewarded decent living and participation in sacraments; the Church would do the rest. ${ }^{24}$ 
Appropriate Catholic Christian living could take on any number of different forms, but at its core, required good deeds and regular attendance at church where one could have one's sins absolved and take part in Holy Communion. The Catholic priest or bishop's apparel consisted of a set of articles that identified his ability to absolve people of their sins, to sanctify water and objects, and to transubstantiate bread and wine into the body and blood of Christ during Mass.

The Protestant clergy's clothing similarly identified its particular roles in the lives of their congregation. The religion of the English Church after the Reformation advanced a very different understanding of Christianity from Catholicism, one divested of ritual, and offering a far more limited range of possibilities for the devout individual. Haigh explains:

If a Christian would be saved, he or she must be a thinker: a sermongoer, a catechism-learner, a Bible-student, an earnest prayer, a singer of psalms; indeed, to be a real Christian at all required sermon, catechism, Bible, prayer, and psalms. It was not enough—it was not much at all—to go to church and recite prayers; it was worthless to live charitably with one's neighbours, unless good living came from right faith. ... Protestantism was not a works religion, it was a Word religion: the Word preached, the Word read, the Word sung to the Lord, the Word applied to life, the Word wrestled with in the heart of a sinner yearning for grace. ${ }^{25}$

The English Church was specific about what was expected of its adherents. Appropriate Protestant Christian living required that one engage the Holy word 
directly and seek God's forgiveness on one's own. Indeed, in this formulation of Christianity, the church was significantly less important for it did not play any ritual role in the salvation of its adherents. The Latin Mass was replaced with a vernacular liturgy; transubstantiation was replaced by metaphor: the bread and wine now stood for the body and blood of Christ with the taking of communion serving merely as a reassertion of one's faith and not a necessary step towards salvation. In the Protestant church, the clergy were allowed to marry and had closer contact with regular society than their Catholic counterparts. Divested of its mystical purpose, the English clergy after the reformation served the function of religious educator. The Protestant minister was a teacher to his congregation, using didactic lectures to explain the bible and eradicate ignorance and superstition. Accordingly, the attire for such a clergy was the scholar's gown which identified the wearer, both in English society and on the stage, with his role as a religious professor.

By presenting a contrast between Protestant minister's gowns and Catholic vestments, Middleton established the dramatic territory on which he could visually deconstruct the tenets of Catholicism through the course of his play. The preponderance of this deconstruction takes place in the actions of the Black Bishop's Pawn which serve to systematically belie the holy functions of the Catholic priest and betray the religious purpose of his holy habit. Middleton makes little effort to proffer the White Bishop or his Pawn as significant voices for the true church. Rather, he focuses his attention on showing the Catholic clergy as mendacious, cruel, lascivious, and ungodly. 
Of course, Middleton depicts the Catholic Church as thoroughly corrupt before the Black Bishop’s Pawn ever enters upon the stage. Ignatius Loyola presents himself in no uncertain terms as an evil, power-hungry schemer:

Hah! Where? What angle of the world is this, That I can neither see the politic face Nor with my refined nostrils taste the footsteps Of any of my disciples, sons and heirs As well of my designs as institutions? I thought they'd spread over the world by this time, Covered the earth's face and made dark the land Like the Egyptian grasshoppers. Here's too much light appears shot from the eyes Of truth and goodness never yet deflowered; (1.1.1-9) The image of Jesuits that Ignatius presents is an extreme one, but it is not dissimilar to how Catholics were widely depicted in Protestant writing (not merely Puritan). As historian Roger Lockyer has noted, "the history of England in the seventeenth century is incomprehensible without taking into account the hysterical anti-Catholicism that coloured popular attitudes: to call a man a papist was to accuse him of the vilest perfidy and treachery."${ }^{, 26}$ Middleton depicts Ignatius as a caricature of evil, but it was the way he was likely understood by his audience. In England's collective memory, the Gunpowder Plot of 1605, when Catholics led by Guy Fawkes attempted to blow up the Houses of Parliament with all the royal family, was still fresh, its foiling the cause for annual celebration (which continues to this day). In 1619, the continent was 
riddled with conflict as Catholic Spain pursued open war with the Protestants in the German states, most notably Frederick V, Elector of the Palatinate of the Rhine, who was married to the English Princess Elizabeth. ${ }^{27}$ The Spanish-born Ignatius embodied the fear and anger the English had toward Spain, the most powerful Catholic country in Europe.

What distinguishes the actions of the Black Bishop’s Pawn from the words of Ignatius, however, is that the Pawn primarily pursues the religious functions promised by his apparel. He has political significance as well, but only in the form of metaphor: the perfidious Catholic cleric unsuccessfully attempts to corrupt and seduce the innocent, virginal English maiden (the White Queen’s Pawn). The actions that the Black Bishop’s Pawn pursues relate specifically to his profession as a representative of the Catholic Church. Significantly, his apparel is frequently mentioned and serves an important function in his designs.

When he has decided to pursue the White Queen’s Pawn, the Black Bishop’s Pawn's opening thought is to win her through the visible display of his religious power: "Let me contemplate, / With holy wonder season my access, / And by degrees approach the sanctuary / Of unmatched beauty set in grace and goodness” (1.1.70-3). The Catholic vestments were, in and of themselves, an affront to Protestant thought. As Robin Clifton explains, “Catholicism’s elaborate cycle of observances, its complex ritual and dramatic ceremonial, drew biting criticism from most Protestant writers. ... This complex ceremonial resulted in part from the laity’s weak preference for a spectacular and visible religion, but equally relevant was the clergy's desire for power.”28 By appealing to his “holy wonder,” the Black Bishop’s Pawn highlights 
what the English considered to be the hypocrisy of Catholicism: its reliance on literally spectacular deceit at the expense of true religiosity.

Continuing to pursue his religious function, the Black Bishop’s Pawn entices the White Queen's Pawn to become a Catholic. She readily accedes to his wishes, taking his pious figure to represent an equally pious heart. Middleton has her become a Catholic so that the religion's duplicity and wickedness could be shown from within. The White Queen's Pawn's first undertaking as a newly converted Catholic is confession. The Black Bishop’s Pawn promises that the practice will "make your merit, which through erring ignorance / Appears but spotted righteousness to me, / Far clearer than the innocence of infants” (1.1.87-9). However, in an aside he marks the true purpose of taking confession:

Now to the work indeed, which is to catch

Her inclination; that's the special use

We make of all our practice in all kingdoms,

For by disclosing their most secret frailties, Things, which once ours, they must not hide from us, (That's the first article in the creed we teach'em)

Finding to what point their blood most inclines, Know best to apt [adapt] them then to our designs. (1.1.108-15). The confessional is not a Protestant practice. The implication in A Game at Chess is that the Catholic clergy acknowledges the ungodliness of its practices and purposefully uses its holy office to further its impious designs. Accordingly, in the next act, the Black Bishop’s Pawn instructs the White Queen’s Pawn that obedience 
is a fundamental principal of Catholicism, and then demands that she have sex with him, reprimanding her for breaking her religious duty when she has the audacity to demur. The White King explains how the deeds of the Black Bishop’s Pawn are vile in and of themselves, but take on a far more pernicious aspect as a result of his religious clothing:

When we find desperate sins in ill men's companies

We place a charitable sorrow there,

But custom and their leprous inclination

Quits us of wonder, for our expectation

Is answered in their lives; but to find sin,

Ay, and a masterpiece of darkness, sheltered

Under a robe of sanctity, is able

To draw all wonder to that monster only (2.2.127-34)

The clear argument in A Game at Chess is that the "masterpiece of darkness" is endemic to the "robe of sanctity" worn by the Catholic Clergy; the vestments signify darkness where they should signify light.

According to the logic of A Game at Chess, the Catholic religion is, itself, little more than a masquerade. Costume serves a function for the clergy who employ it to bewilder people into believing in their holiness and accepting the tenets of their religion which serve merely to extend the reach of their power. This view of Catholicism is further supported by the Black Bishop's Pawn's willingness to take off his religious vestments and put on a different costume when he believes it will help him to more effectively pursue his designs. In 3.3, the Black Bishop’s Pawn appears, 
according to the text, in "rich attire" or "richly accoutred" as part of the Black Queen's Pawn's plan to snare the White Queen's Pawn and trick her into having sex with the Black Bishop's Pawn. Since priests are bound to a life of poverty, ${ }^{29}$ the Black Bishop’s Pawn's change of clothing into expensive apparel is a double offense.

The White Queen’s Pawn falls for the Black Queen's Pawn's ruse. She believes in the power of the Black Queen’s Pawn's magical glass and, consequently, accepts that the costumed Black Bishop’s Pawn is her future husband. However, the White Queen’s Pawn's inherent innocence demands that she be married before she go to bed. This request gives the Black Bishop's Pawn pause, for his holy vows will not permit him to take a wife. Swapan Chakravorty has suggested that the Black Bishop's Pawn's last-minute qualms derive from his vow of celibacy, ${ }^{30}$ but his earlier attempt to rape the White Bishop’s Pawn and the Black Queen’s Pawn’s accusation that he has fathered bastards suggests that the vow to which he refers is the public vow of matrimony and serves merely as a last minute reminder of the private religious hypocrisy he is about to take part in. He has taken off his clothing and just as easily removed any semblance of morality.

Throughout A Game at Chess, Middleton stresses the notion that one’s clothes should represent one's identity and that the ability to change apparel demonstrates the vilest deceitfulness. This understanding of clothing has an antecedent in morality plays and interludes in which only Vice characters disguised themselves. As MacIntyre and Epp note, most costume changes in early traditional drama have negative implications - a visible rendering of the doctrine that, since God is unchanging, changeability is itself a sign of ungodliness. ${ }^{31}$ The Black Bishop’s Pawn 
provides the most potent example of this, but not the most conspicuous one. The clearest example of the perfidy attached to the changing of one's apparel can be found in the actions of the White King's Pawn who changes sides onstage through the removing of his white upper garment to show black underneath. Holles mentions it in his letter:

one of the white pawns, wth an vnder black dubblett, signifying a Spanish hart, betrays his party to their avuantage, auanceth Gundomars propositions, works vnder hand the Princes cumming into Spayn: which pawn so discouered, the whyt King reuyles him, objects his raising him in wealth, in honor, from mean[d]e condition, next classis to a lab[r]ouring man: this by the character is supposed Bristow. ${ }^{32}$ It is likely that the character wore a white jerkin or jacket on top of his black doublet earlier in the play and simply took it off to show his "Spanish hart.” However, the White King's Pawn provides a special problem. He is identified by Holles as the Earl of Bristol but is understood by most modern critics to represent Lionel Cranfield, Earl of Middlesex and Lord Treasurer. Cranfield would have fit the character of the White King's Pawn as well as Bristol in August of 1624: he was impeached by the House of Commons in May 1624, the month before Sir Henry Herbert licensed A Game at Chess for performance. Indeed, the White King's Pawn also has some characteristics of Sir Toby Matthew, an English Catholic who was pro-Spanish. ${ }^{33}$ Looking at the various historical individuals, A. R. Braunmuller has concluded that "we may never know - reading Holles' letter and other seventeenth- and twentieth-century accounts suggests it is self-defeatingly arbitrary to ask - whether some, or most, of the 
spectators at the Globe understood the White King's Pawn to represent the Earl of Middlesex or the Earl of Bristol, or some other contemporary figure, or an amalgam of several figures, or none. ${ }^{34}$ What is certain is that seemingly loyal English subjects may have inner identities that belie their outward appearance and that true subjects of the crown must be vigilant against those who might change their apparel and reveal their Catholic or Spanish allegiance.

It is in view of this attitude toward the changing of one's clothing that the Fat Bishop was likely understood. Clearly representative of Marc Antonio De Dominis, the Fat Bishop's actions are based on historical fact. Beginning the play as a member of the White House, the Fat Bishop represents De Dominis after he left his Archbishopric of Spalato and converted to Protestantism. His conversion in the play to the Black House represents De Dominis’ decision in 1622 to leave England and convert back to Catholicism. With a character whose actions mirror historical events this closely, it may seem that the character's clothing would serve no greater purpose than to identify him as the turncoat that he was understood by the audience to be. However, the manner in which the character was dressed likely had a large impact on how he was perceived onstage. And yet, it is difficult to determine the specific apparel he wore. We can say with some certainty how he was costumed once he converted to the Black House. When he revealed his new allegiance, the Fat Bishop probably wore the vestments appropriate to his renewed Catholicism and looked more or less similar to how he appears on the cover of the First Quarto. His visible transformation can be noted in the first lines he speaks after changing sides. Shortly 
after the White King's Pawn reveals his black apparel and shows his loyalty to the Black House, the Fat Bishop enters:

FAT BISHOP: Is there so much amazement spent on him

That's but half black? There might be hope of that man;

But how will this House wonder if I stand forth

And show a whole one, instantly discover

One that's all black where there's no hope at all?

WHITE KING: I'll say thy heart then justifies thy books;

I long for that discovery

FAT BISHOP: Look no farther then:

Bear witness all the House I am the man

And turn myself into the Black House freely;

I am of this side now. (3.1.281-90)

The Fat Bishop’s lines signify that he previously wore white to identify himself as a member of the White House, but now chooses to don the black color that demonstrates his new allegiance. Indeed, his Catholic vestments and his position on the cover of the First Quarto suggest to readers that he stands in moral opposition to the White Bishop.

Before he changes sides, however, it is difficult to determine if the Fat Bishop wore the academic robes of the Protestant clergy or white Catholic vestments . To fit with the Protestant ideology that he had ostensibly embraced before the start of the play, the Fat Bishop would have needed an academic gown. And yet, two points need to be raised. First, the audience would have known who he was and how he had 
switched allegiances from Catholicism to Protestantism, and then back to Catholicism only two years before. Accordingly, he was widely known as a turncoat and would have been a target of the audience's derision wearing the clothes of a Catholic while basking in the protection of the White house. This hypocrisy informs the Fat Bishop's first lines which suggest that despite his membership in the Protestant White House, he wears clothes that identify him with Catholicism:

FAT BISHOP: Pawn!

FAT BISHOP’S PAWN: I attend at your great holiness' service.

FAT BISHOP: For great I grant you, but for greatly holy,

There the soil alters. Fat cathedral bodies

Have very often but lean little souls (2.2.1-5)

His "fat cathedral body" would seem to suggest that the actor was corpulent and draped in visibly Catholic apparel..$^{35}$ And yet it is possible that the Fat Bishop is merely drawing attention to his former Catholicism so as to make certain the audience recognizes whom he represents underneath Protestant clerical robes.

The second point we should consider is the title-page of the Third Quarto which differs from the First Quarto in placing the Fat Bishop (although not named) on the side labeled "the White House." 


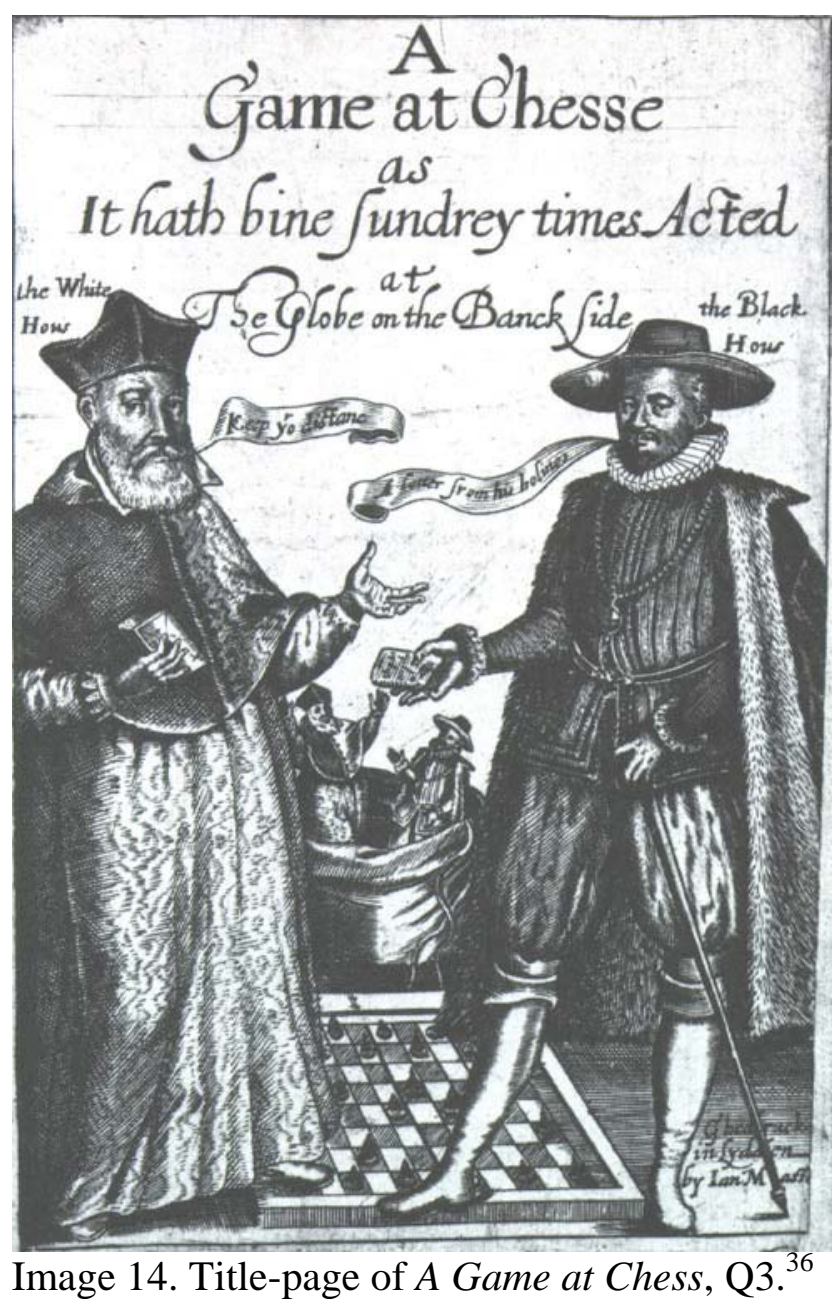

For those who purchased this Quarto of the play without seeing it performed, the only image of the Fat Bishop available is one in which he wears Catholic vestments and is situated diametrically from the Black Knight. The nature of the title-page prints for all the Quartos is such that it is difficult to determine with certainty if the Fat Bishop's clothes were intended to be black or white. Indeed, the Fat Bishop appears the same in both the First and Third quartos, and yet the house to which he belongs has changed. 
Ultimately, I am swayed by the Fat Bishop's opening lines into believe that he wore white Catholic vestments when he first entered upon the stage, but the historical evidence is by no means definitive. What is certain, however, is that in either configuration, the Fat Bishop is earmarked for our scorn by his decision to alter his apparel and change sides. The willingness to change clothes, in and of itself, signifies immorality, for it suggests that outer garments can hide a disloyal heart. The Black Knight drives home the very real danger inherent in the Fat Bishop’s proclivity to change apparel when he notes how many in England currently wear English clothes that hide their true loyalty to Spain and their desire to spread Catholicism.

For venting hallowed oil, beads, medals, pardons,

Pictures, Veronica's heads in private presses, That's done by one i'th'habit of a pedlar;

Letters conveyed in rolls, tobacco-balls.

When a restraint comes, by my politic counsel

Some of our Jesuits turn gentlemen-ushers,

Some falconers, some park-keepers, and some huntsmen;

One took the shape of an old lady's crook once

And despatched two chores in a Sunday morning, The altar and the dresser! (4.2.48-57)

This danger is contained in A Game at Chess when, at the end of the play, all those who would betray their apparel are safely put away in the bag, the chess game's symbolic representation of either death or hell. Moreover, the literal turncoats are bested by the White Knight and the White Duke who visit the Black House and 
suggest that they are willing to negotiate a marriage, but never take off the white clothes that signify their true, English, Protestant hearts.

Thus far, little attention has been devoted to the White King and the Black King. The practice of overlooking these characters is not uncommon in studies of Middleton's play since the two have very small roles. And yet, in light of the significance of the characters they represent (the monarchs of England and Spain respectively) and the importance of the King to the game of chess, it would appear that these two characters should be considered much more closely. As noted above, Don Carlos de Coloma stated that the Black King was identifiable as the King of Spain "because of his youth, dress, and other details." Costuming a character in $A$ Game at Chess so that he would be identifiable as the King of Spain would not have been difficult (although very few of the people in the audience had likely ever seen Philip IV). However, the suggestion that the character was young carried with it particular associations at the time.

The most obvious way in early modern England by which youthfulness could be depicted onstage was through the use of an actor who has no facial hair. While this has small significance today, it would very likely have been offensive to the Spanish at the time. As Will Fisher has argued and I noted in the first chapter, "facial hair often conferred masculinity: the beard made the man.”37 In As You Like It, Jaques highlights the importance of facial hair when he describes the ages of man: compare the "whining schoolboy, with his satchel and shining morning face, creeping like snail unwillingly to school" to the "soldier, full of strange oaths, and bearded like the pard” (2.7.145-50). ${ }^{38}$ Fisher takes this argument further, suggesting that boys (males 
without facial hair) were literally a different gender from men during the early modern period. He cites Beatrice in Much Ado About Nothing who questions the usefulness of a beardless youth, saying "What should I do with him? Dress him in my apparel and make him my waiting-gentle-woman?” (2.1.34-5). A man without facial hair, Fisher suggests, was considered fit for no greater duties.

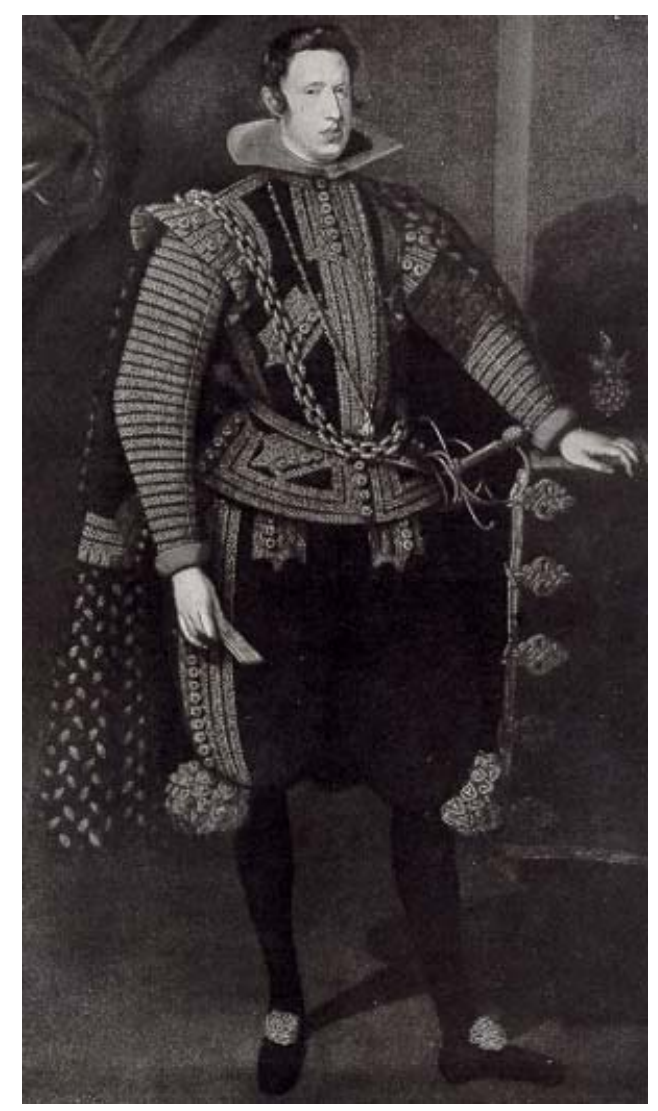

Image 15. Philip IV at age 20.

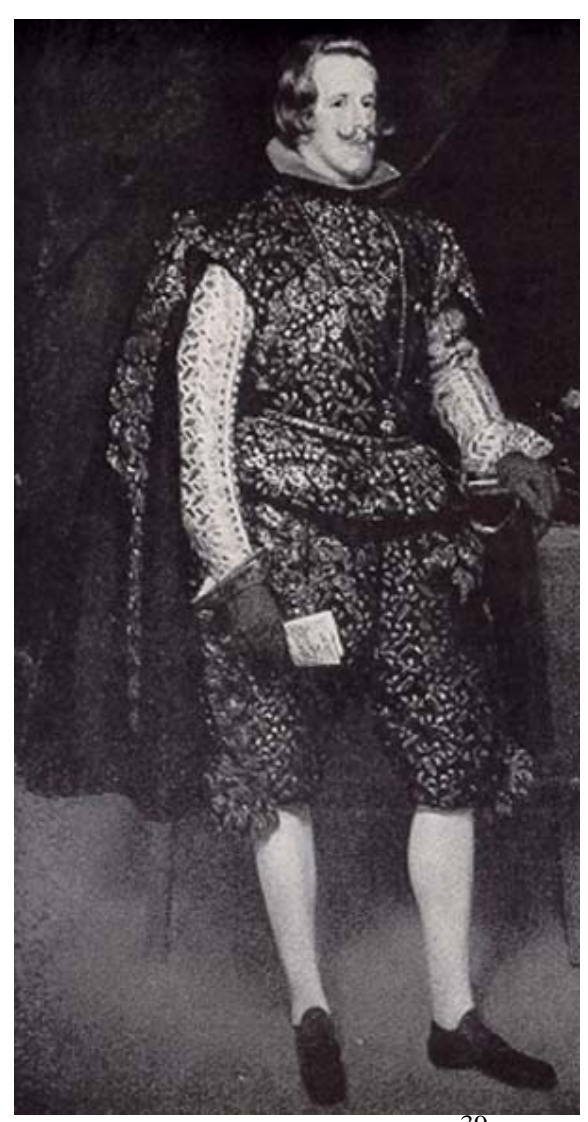

Image 16. At age $27 .{ }^{39}$

The fact that the title-page of A Game at Chess represents the Black King's youth by presenting him without facial hair corroborates the likelihood that the character's youthfulness was depicted onstage through the absence of a mustache or beard. And it is historically accurate. A portrait of Philip IV, completed in or around 
1625, shows the twenty-year-old Spanish monarch with a clean face. This was not likely by choice, however. Very few portraits depict Spanish Men without facial hair at the time, and all later representations of Philip present him with a full mustache. The visual representation of Philip's unmanliness is particularly significant to $A$ Game at Chess because of the Black King's relative unimportance to the development of the play. His actions do not motivate the plot, but his fall is understood, by the rules of chess, to signify the end of the game. By entering upon the stage without a beard, the character serves the performance much more fully than he does the written script. Without uttering a word, he suggests that England's Catholic rival is led by an unmanly whelp. In direct opposition, Moore notes, the character depicting James I appears on the title-page as a rather elderly man bearded like the royal head on the gold sovereigns called "jacobuses." ${ }^{40}$ There is little to suggest what was worn by the character playing the White King in production, but it seems safe to assume that a play with the political biases of A Game at Chess would present him with the reverend and respectable countenance owed to the monarch who both ruled the country and was the royal sponsor of the acting company.

Costumes and apparel informed the substance, the staging, the publication, and the reception of Middleton's 1624 performance of A Game at Chess. Indeed, Middleton equates the practice of playmaking with fashion in the epistle to The Roaring Girl:

The fashion of play-making I can properly compare to nothing so naturally as the alteration in apparel: for in the time of the great-crop doublet, your huge bombasted plays, quilted with mighty words to lean 
purpose, was only then in fashion; and as the doublet fell, neater inventions began to set up. Now in the time of spruceness, our plays follow the niceness of our garments: single plots, quaint conceits, lecherous jests, dressed up in hanging sleeves; and those are fit for the times and the termers. ${ }^{41}$

In his efforts to fit A Game at Chess to the "times and the termers," Middleton skillfully employed costumes to establish who his characters represented and how the audience should understand them. 


\section{CHAPTER 5}

\section{THE LORD MAYOR'S SHOW}

The Lord Mayor's Show developed over the centuries as part of the annual inauguration of the new mayor of London. Long before the investiture of the Lord Mayor was celebrated by emblematic performances on multiple, elaborately decorated pageant wagons, the day was marked by the newly elected official taking part in a public “riding” to Westminster to take an oath of loyalty to the King. In this riding, the history of which can be dated to $1236,{ }^{1}$ the new Lord Mayor was accompanied by the aldermen, sheriffs, city officers, and his own guild liverymen, all wearing the apparel that publicly denoted their social status and membership in the city guilds. Over time, the nature of the Lord Mayor's progress changed a great deal. In 1453, the trip to Westminster was made on the Thames in a decorated barge. This became a regular part of the journey, and soon all of the livery companies welcomed the new Lord Mayor to his progress across the water in adorned barges of their own. Starting in 1535, the Lord Mayor's progress expanded in expenditure and lavishness, incorporating a pageant wagon and a tableaux such as those which had been a part of

the Midsummer Show. ${ }^{2}$ This tableaux was accompanied by speeches. In the Jacobean 
period the number of pageant wagons and speeches increased, sometimes taking on the dramatic qualities of morality plays.

These Jacobean pageant wagon performances, many of them written by professional dramatists (e.g., Middleton, Dekker, and Heywood each wrote several), are often the focus of studies of the Lord Mayor's Day, frequently to the exclusion of the procession itself. This practice of looking primarily at the pageant wagon performances serves to ignore the history of the Lord Mayor's show and does an injustice to the manner in which the event was experienced in early modern London. As James Knowles explains, "the familiar overemphasis upon the pageants distorts the nature of the Lord Mayor's show itself, in that it fails to consider the various signifying elements deployed, such as processional order, liveries, and guild symbolism.”3 The Lord Mayor's parade served as a performance in its own right, one which was costumed and carefully orchestrated to elicit a particular effect within a historically determined milieu.

A survey of the conditions surrounding the performance and reception of the Lord Mayor's shows in early modern England suggests that the progress of the newly elected official was the main event of the day and the pageants were accessories, supporting the magnificence of the man they intended to honor. Before the accession of James I, the Lord Mayor's shows typically employed only a single tableau. The extant documentation from this period suggests that the pageant performances were typically brief, consisting of no more than a few minutes of speech. But the significance of the pageant wagon itself did not end after the speeches were concluded. When the performance was over, the pageant wagon would enter the 
procession and be pulled through London in front of the Mayor. The fact that the Lord Mayor’s procession began in the morning and ended at night puts the importance of the pageant in perspective. Consequently, the pageant wagon deserve consideration as a part of the visual spectacle of the parade.

In the first decade of the seventeenth century, the Lord Mayor's show began to include multiple pageants (typically five or six), and longer, more involved speeches. This suggests that the dramatic aspects of the pageant were becoming more important. And yet, the focus of the day remained on the procession. Very few of the people who attended the Lord Mayor's show would have had the opportunity to hear more than one or two of the pageant speeches presented before the Lord Mayor. The streets on October 29, the annual date of the new mayor's progress, were typically so crowded that whifflers had to be appointed with the responsibility of clearing the streets in front of the procession. Lupold Von Wedel, who watched a Lord Mayor's show during his journey through England and Scotland in 1584 and 1585, noted that the streets were "quite filled with people" and that, at the head of the procession, there were "some fire-engines ornamented with garlands, out of which they throw water on the crowd, forcing it to give way." ${ }^{4}$ Orazio (also spelled "Horatio") Busino, chaplain to the Venetian Embassy, had a similar experience when he saw the Lord Mayor's progress in 1617. He recorded:

To clear the way, the City Marshal on horseback, with a gold collar round his neck, and two footmen in livery, kept parading up and down: he was so smooth and sleek that we unhesitatingly pronounced him to be of the swinish race of jolly Bacchus. The way was also kept by a 
number of lusty youths and men armed with long fencing swords, which they manipulated very dexterously, but no sooner had a passage been forced in one place than the crowd closed in at another. There were also men masked as wild giants who by means of fireballs and wheels hurled sparks in the faces of the mob and over their persons, but all proved unavailing to make a free and ample thoroughfare. ${ }^{5}$

London was the most populous city in England and most of its citizens seem to have come out to witness the day's events.

Commentary from the period shows that spectators tended to observe the procession from a single location where they might catch one of the pageant performances, and then they moved to another location where perhaps they would observe other aspects of the celebration. It would have been nearly impossible, however, to see and hear the full performance. Still, the spectators would have had a chance to see the pageant wagons, for the carts would join the procession after the performers had delivered their speeches. As Gordon Kipling notes, “as a Londoner watched this spectacle of procession and pageant from his 'standing' along the street, who could blame him from thinking himself the true audience for whom this show was designed? . . . For such an audience, the triumphator [Lord Mayor] ... would seem the protagonist of a drama which takes all London as its stage.”6 Orazio Busino watched the show from two different vantage points, and although he briefly describes the shapes of the pageant wagons, he does not mention the speeches at all. Rather, he devotes the majority of his commentary to describing the procession. 
Of course, it would have been extremely difficult to hear the pageant speeches even if one were relatively close to the performers. The large crowds that necessitated whifflers in order for the Lord Mayor's entourage to proceed through the streets no doubt created a level of ambient noise far greater than that which would have been found in the public playhouses. Additionally, many of the actors in the Lord Mayor's shows were children. When we consider the rich language written for the children's troupes by Ben Jonson, there is little doubt that the "little eyases" would have been audible when performing at the indoor theatres in front of 500 or fewer people. But surrounded by many thousands in the street on a day of festivity, the children were unlikely to be heard even by the Lord Mayor himself. ${ }^{7}$ Such was Queen Elizabeth’s experience in 1558 when she rode her chariot from the tower to Westminster the day before her Coronation. As Robert Withington explains, "because of the press of people, Elizabeth could hardly hear the child-interpreter, and as her chariot was stopped so that she could not well see the personages in the pageant, she had it moved back, and the whole matter explained to her.” ${ }^{8}$ Despite the fact that the Lord Mayor was the subject and the ideal audience for the show, it seems likely that his experience trying to hear the children would have been little different from that of Queen Elizabeth.

This is not to suggest that the words spoken in the Lord Mayor's show were unimportant, for as early as 1566 souvenir copies of the shows were being printed privately for members of the sponsoring guild. By the beginning of the seventeenth century, it became common practice for guilds to pay for 500 copies of the show to be printed. Thus, the words written by the poets for the pageants would have found an 
audience, but it was a vastly smaller one than that which filled the streets every year to watch the Lord Mayor's procession through the streets of London.

Consequently, the Lord Mayor's Day events, more than the productions of the professional companies, the children's troupes, or even the court masques, deserve consideration primarily as a visual spectacle. As D. J. Gordon and Jean Robertson explain, "The crowds did not, of course, assemble to listen to poetry; they wanted to see the procession and the pageants." ${ }^{, 9}$ What then was the nature of this spectacle and according to what codes was it understood by the enormous multitude of people who watched it? ${ }^{10}$

One of the keys to understanding the visual elements of the Lord Mayor's Day is the political function which it served. The early modern Lord Mayor's show, like all civic pageantry, was an artistic medium shaped by an explicitly political context. ${ }^{11}$ As Knowles explains, “civic ceremony propagated civic ideology, promoted the internal stability of the City through the exhortation to and ritualisation of order, and demonstrated that stability to the wider national audience."12 This was accomplished through the costumed staging of London's body politic in a magnificent parade that served not merely to reflect the social stratification of society but also to reify, legitimize, and celebrate that stratification.

The dearth of visual evidence from the period complicates the process of ascertaining precisely what was worn in the early modern Lord Mayor's Day processions. That stated, commentary from the period coupled with guild records and other historical data provide enough information to paint a fairly rich picture of the processions as they likely appeared in the late sixteenth and early seventeenth 
century. What we find is that the new mayor's progresses encompassed the social breadth of the city. Within the Lord Mayor's retinue was the full range of London's population, from the outgoing mayor, the sheriffs, and the alderman - the most powerful men in the city - to poor men who were costumed and employed specifically for the day's procession. The wide variety of individuals taking part in the procession may explain Bussino's (and others') decision to focus attention on the Lord Mayor's entourage instead of the pageant wagons: within the mayor's procession, there were hundreds of people in expensive, elaborate, symbolically significant apparel; additionally, ranks of musicians playing drums, trumpets, and flutes accompanied the guild officials on their progress. Even without the pageant wagons, the Lord Mayor’s procession was an extraordinary spectacle.

The Lord Mayor's Day took place annually on October 29, but the experience of one who witnessed the festivities surrounding the installation of the new city official suggests that the event began the day before. It is on October 28 that the old mayor officially transfers authority to the new. Like all such instances in which power circulates in early modern England, the event was a public one, and it was significant enough to draw the attention of Lupold Von Wedel, a German-born visitor to England who recorded what he saw in 1584 in considerable detail. The fact that scholars rarely address this aspect of the new Lord Mayor's commencement ${ }^{13}$ warrants an extended quotation of Von Wedel's description of the day.

The megger [mayor] in office goes to the town hall followed by the new candidate. They both wear long coats of a brownish violet coloured cloth, lined with marten, and over these other coats of the same colour faced with calabar-skins, the latter hanging down on the back and turned up on the sides. On their heads they wear black caps, and a sceptre and sword were carried before them. After them marched 
twenty-four councillors clad in the same manner, and in the town hall stood forty-eight men, twenty-four on each side, in long black coats also lined with marten, wearing on their backs large bags (hoods) like those which in Germany the shepherds use, of cloth half red half black, with a bandelier of the same colours over the shoulder and fastened before the chest. When the council has reached the platform the present burgomaster and the one which is to come are seated behind a small table, and then the macebearer advises three times all present to pay attention. Then he takes a book, and he and another gentleman, kneeling down on cushions placed on both sides of the table, they read the oath which the new megger has to swear. After this ceremony they all go out again, but now the late megger following the newly elected. Before going out, the two meggers and the council had taken off their overcoats faced with calabar, keeping on only those lined with marten, over which they had large golden chains hanging down in front and on the back as far as the girdle. The queen gives such a chain to every new elected burgomaster, the members of the (town)-council who have been elected meggers once before, wear likewise such chaines, the other have only stripes of black velvet on their coats about a handbreadth broad. The two meggers as well as the council left on horseback, also two secretaries, who rode behind the council. They were clad in similar coats as before said, wearing golden chains beneath their coats. The men with the coloured bags (hoods) marched before and accompanied the new megger to his house. ${ }^{14}$

Like the Lord Mayor’s Show, the events of October 28 constitute a highly visible, public event. Were the ceremony a private one, Von Wedel, a foreigner, would not have had the chance to see and record it. Moreover, it involves an impressive procession, costumes, and accoutrements.

The prescribed apparel and the order of presentation establishes the individuals in a particular hierarchy and as players in a social performance. The two Lord Mayors, one incoming and the other outgoing, are similarly dressed in robes of brownish violet and proceed to the town hall together with the new mayor following the one who is, at this moment, still in office. Behind them march the aldermen who affirm their own importance and the significance of these two men by following their 
procession in similar apparel. The social status of these men in colored robes is made more conspicuous when they appear in contrast to the forty-eight guild masters dressed in black with hoods that are half red. The ceremony of the transfer of power and its particular public presentation have been established by long tradition and are unchangeable. ${ }^{15}$ They are repeated every year to solemnize and make potent the public speech-act or performative utterance, ${ }^{16}$ whereby the new mayor takes the oath of office and assumes the authority of the old. The potency of the words spoken prompts the transfer of the seal, sword, and scepter to the new mayor who then walks home at the head of a procession including the old mayor and the rest of the city officials.

Although far smaller in scale than the triumph ${ }^{17}$ that marks the Lord Mayor's Day, the events of October 28 constitute a public performance of its own. The robes that all of the guild members wear identify the city elite as joint members of London's government. Thus, despite the considerable competition between the companies for profit, their apparel serves to establish and demonstrate a shared identity. John Astington has suggested that in this procession, the frank use of costume as display tends to underline the theatrical nature of much social ordering, and hence can ironically unsettle the supposed solidity of rank, station, and authority as much as it emphasizes them through impressive spectacle. ${ }^{18}$ Although Astington's argument may hold true for many parades today, it is not necessarily true for the Lord Mayor's procession. The robes worn by the guild masters, the aldermen, and the mayors are not metaphors for their authority, but metonyms of the office they hold. If the robes were metaphors, their visual significance would end at their emblematic 
function of standing for an office that could be assumed and relinquished like simple articles of clothing. On the contrary, the official robes, although "spectacular" when displayed en masse, were worn at all public guild meetings and were the visual sign of an understood, inner dignity. Moreover, the ability of any man to put on the attire of a particular city office does not necessarily suggest that he is assuming the position since the person in the clothes might be defined by his or her unworthiness to wear them, and not directly by the clothes themselves. Thus, an undergraduate found parading as a doctor during graduation would probably not be a source of humor, but would raise the ire of all involved in the ceremony, from undergraduates to professors, who see the robes as metonyms that need to be earned - there is no distinction made between the apparel and the work done to achieve it.

Accordingly, we can see that the costumes worn by the city officials in the Lord Mayor's retinue on 28 and 29 October are the opposite of those worn by actors in the early modern playhouses. If an actor puts on a Lord Mayor's robe in the theatre, perhaps while playing Simon Eyre in the original production of Dekker's The Shoemaker's Holiday, the piece of apparel works as a metaphor, defining the individual within the liminal world of the theatre. Outside of the theatre, the same actor would be threatened with fines for wearing theatrical apparel in the streets and in danger of public chastisement or punishment for assuming the identity of a city official.

The procession of October 28, although clearly connected to the Lord Mayor's Day which begins the following morning and highlighting the same city officials, was a discrete performance. Both the procession of October 28 and that of October 29 , 
involve the public presentation of London's governing body, but the purpose for each of the spectacles is distinct. The progress of the new Lord Mayor to the town hall on October 28 serves as a reaffirmation of London's power and its ability to govern itself. The right of the citizens of London to elect their town's leader dates back to 1215, and the inauguration of the Lord Mayor on October 28 exercises and celebrates that power. Consequently, the identical clothes worn by the incoming and outgoing mayors serves to visually represent the continuity of the city's self-governance. The mayor has retired. Long live the mayor.

The procession of October 29 accomplishes something very different from the procession of the day before. Instead of celebrating and reifying the power of the Lord Mayor and the officials of London, the Lord Mayor's Day serves to celebrate and reify the broader political system which identifies the King as the source of the power of the Lord Mayor, and the newly elected official as the representative of the crown's authority in London. The first place where this change in focus can be identified is in the different clothing worn on the $28^{\text {th }}$ and $29^{\text {th }}$ of October by the city elite.

Von Wedel states that the apparel worn by the Lord Mayor and the Alderman for the inauguration at town hall is a robe of brownish violet colored cloth, lined with marten, and over these other coats of the same color faced with calabar-skins. The following day, however, the same officials wear different color clothing. Von Wedel notes this change in his description of the Lord Mayor’s Day procession: “Now followed the two meggers [the old and the new mayors], behind these the council in the same order as yesterday, but in red coats. The burgomasters were clad in the same 
coats. ${ }^{\prime 19}$ Unlike the day before, the Lord Mayor and Aldermen now wear red apparel. As was noted in chapter one, red, or more specifically scarlet, was the color of the court. It was for this reason that, when the King's Men were called upon to take part in King James' progress through London at the beginning of his reign, they were each issued four and a half yards of scarlet cloth for livery. ${ }^{20}$ The city officials' change in apparel similarly serves to identify them as servants of the monarch.

The wearing of scarlet makes particular sense for the Lord Mayor on this day since the one truly ceremonial aspect of the Lord Mayor's Day events is the progress of the newly elected official to Westminster to swear an oath of loyalty to the monarch (or the monarch's official representatives if she or he is away). In 1607, the Recorder's speech at the oath-taking ceremony of Sir Henry Roe makes explicit the duty that the new Lord Mayor owes the King as a consequence of wearing his scarlet robe: "This skarlett, by your Majesties indulgence, is the roabe wherein they triumph, or rather blush that they cannot doe your Majesties that servic wich with all alacritye they desier and owe."21 The scarlet robe visually marks the Lord Mayor’s obedience to the Monarch and legitimizes his authority in London by identifying it as descending from the throne. The fact that all of the surviving accounts of the Lord Mayor's Day from the early modern period mention the new official's trip down the Thames to take his oath suggests the far reaching importance of the new Lord Mayor's apparel and his visit to Westminster. Of course, one might argue that contemporary interest in the mayor's trip to take his oath derives largely from the lavishness of the spectacle presented on the water, but as we shall see, this spectacle supported the purpose of the visit to Westminster. 
In his discussion of the trip down the Thames, Von Wedel notes that the barge employed by the Lord Mayor was red, with a white cross. Other reports from the period make no mention of the color of the barge taken by the new mayor, but the primary purpose of the boat - to present the Lord Mayor before the monarch suggests that red decorations were not unique to 1584 . On other details regarding the trip along the Thames the extant commentary is remarkably consistent, with nearly identical observations being made in reports that are over sixty years apart. In 1553, Henry Machyn, a London citizen and Merchant-Taylor, noted that the Lord Mayor’s barge was launched with musical fanfare and the firing of guns. He additionally states that there were numerous other crafts on the Thames, representing the other guilds, which were decked with streamers and banners:

[The same day the new Lord Mayor ${ }^{22}$ went] toward Westmynter [attended by the] craftes of London in ther best leveray ... with trumpets blohyng and the whets [waits] playng .. a goodly fuyst [foist] trymmed with banars and guns ... waytyng of my lord mayre('s) barge unto Westmynster [and] all the craftes bargers with stremars and banars [of every] craft. $^{23}$

Von Wedel, thirty-one years later, noted that

Each guild or company had its own barge, ornamented with numerous flags by which every company might be distinguished one from the other. ... Besides these, on the river were numerous little boats, altogether several hundred in number, carrying people who wanted to see the splendid spectacle. When the megger stepped into the barge a 
salute of more than a hundred shots was fired, trumpets and musical instruments were heard from all the barges. ${ }^{24}$

Forty-five years after Von Wedel watched the Lord Mayor's show, Abram Booth, a Dutch visitor to England wrote in 1629:

Before this barge of the Mayor followed yet other seventy barges of the 8 Companies and sixty Guilds, every one with its banners, decorated in an artful manner, and finally the barge of the Mayor himself with the Sheriffs and Aldermen of the city, decorated with the banners of the King and the City.

These barges proceeding, there were fired on the way some mortars and fireworks ... ${ }^{25}$

The similarities between these reports are remarkable, particularly considering the time spans separating them and the fact that they were written by spectators from different countries. These likenesses can be at least partially explained by the fact that there was a conscious effort made on the part of the guilds to have the Lord Mayor's Day adhere to tradition. As John Meagher notes, the books of the sponsoring companies repeatedly ordain that the Lord Mayor's solemnities are to be handled in accordance with established custom. ${ }^{26}$ Thus, although we can chart the growth of the Lord Mayor's Show during the late sixteenth and early seventeenth century, it is important to keep sight of those aspects that were carefully maintained throughout the era.

The new Lord Mayor's morning visit to Westminster on 29 October figures importantly in the perpetuity of the day's annual celebration. Only one extant 
contemporary report, Von Wedel's, describes the new Lord Mayor's swearing his allegiance at Westminster, but the event's carefully ordered and processional nature suggests that it is representative of perennial practice. He writes, that when the barge landed, the Lord Mayor followed a large procession, including the guild masters in their robes and colored hoods, 200 men, two sergeants bearing the queen's arms in form of a seal, men with white staffs, sixteen trumpeters, four pipers, two men bearing an incense box, and a man bearing the Lord Mayor's sword. Behind the Lord Mayor followed the old mayor, the aldermen, and seventy men with spears, dressed in blue coats and wearing broad red caps. Behind this procession "followed the whole population, entering the court-house in a crowd, men as well as women, for the English women want to be present on all such occasions. Though the place was very large, there was no possibility to move.”27 Like the oath sworn the day before, the new Lord Mayor's oath of allegiance to the monarch (or in this case, to the Chancellor of State who served as the queen's deputy) is a highly public event.

The result of this public display is an assertion and reaffirmation of the power relations that define the political makeup of London society. As Knowles explains, "the Westminster oath-giving, marked by a symbolic use of location, where the mayor travels to the seat of national government, differentiates the mayor by placing him in a hierarchy of relations, and reminds the audience of the chain of government that descends from God to king to mayor."28 The significance of this symbolic use of location is heightened by the guilds' lavish escort over the Thames. By conducting the new lord mayor to Westminster with an armada of elaborately decorated barges from which music is played and shots are fired, the London guilds demonstrate their 
own magnificence, but place that magnificence in the service of celebrating the power of the monarch who receives the new city master and accepts his obeisance.

This is not to suggest that there was perfect amity between the city of London and the crown. Indeed, it can be suggested that, were there perfect amity, there would be no need for a public display of the Lord Mayor's oath of allegiance. Perhaps there is some merit in considering the Lord Mayor's oath as analogous to the "Apology" that was appended to John Stowe's Survey of London, which was directed against "the opinion of some men, which think that the greatness of that City standeth not with the profit and security of this Realm., ${ }^{29}$ Both the Lord Mayor's oath of fealty and the apology draw attention to the very anxieties that they seek to allay. The Lord Mayor's Show in 1605, written by Anthony Munday, pursues this peacekeeping agenda far more actively through its speeches and pageants which celebrate the new King of England every bit as vigorously as they do the new mayor that they were ostensibly written to honor.

The title of the 1605 show was The Triumphes of Re-United Britannia, and, as David Bergeron notes, "no other Lord Mayor's show so consciously, explicitly, and unrelentingly refers to the sovereign.” Bergeron offers an explanation for this show's focus by suggesting that Munday may have been casting his eye toward the court for further employment (and he was successful - in 1610, he was hired to write a pageant honoring Prince Henry). ${ }^{30}$ However, this raises the question: why would the Merchant Taylor's guild agree to have their Lord Mayor's show written to pay homage to the monarch when this had never been the practice before? It must be remembered that before Munday could have written the final text of his show and had it publicly 
performed, he would have first needed to present his ideas before the Merchant Taylors for their approval. The fact that the show was approved, and that Munday went on to write numerous additional shows (including the very next show provided by the Merchant Taylors in 1610) indicates that the subject matter of The Triumphes of Re-United Britannia was agreed upon by the officers of the guild, and perhaps even determined by them. One can imagine that after the long, prosperous reign of Elizabeth, the London officials felt threatened by the incoming King and decided to publicly assert their obedience lest the new monarch seek to curtail the authority and power that they exerted over the city.

And yet, despite the unique focus of the pageant performances employed in the 1605 Lord Mayor's Day, the overall focus of the day's spectacle was the same as it had been in years before and in the years that followed: to celebrate and legitimize the political and social system whereby the Lord Mayor, and by extension all of the Guilds, maintained their authority in London. As Knowles states, “Civic ceremony seeks to embody reconciliation and inculcate order, not simply in its explicit rhetoric, but in its very form, especially the processional element, which actually manifested the whole social body and constitution of the City for its citizens. ${ }^{31}$ In The Triumphes of Re-United Britannia in 1605, the reconciliation and inculcation of order was attempted through public speeches that dually honored the king and the new Lord Mayor. In the processions that marked all of the Lord Mayor's shows throughout the early modern period, this was accomplished through the public spectacle of one's apparel and one's place in the parade, which served to locate one in an ordered and clearly demarcated social hierarchy. 
Only one pictorial representation of a Lord Mayor's procession exists, and it dates from 1614-1615 (see image 17). ${ }^{32}$ In the picture, the Lord Mayor is easily identified at the center on horseback. Although the picture is in black and white, the lighter color of the mayor's scarlet robes can be noted. He wears a medium-brimmed, tall black hat and a broad, multi-layered ruff. Around his neck hangs the gold chain of his office. Behind him, almost identically appareled, ride the sheriffs and then the aldermen lined up two by two. The gold chain that can be seen around some of their necks signifies that they have previously held the office of mayor. The man who walks immediately before the new mayor can be identified as the sword bearer, wearing the "cap of honor.” 


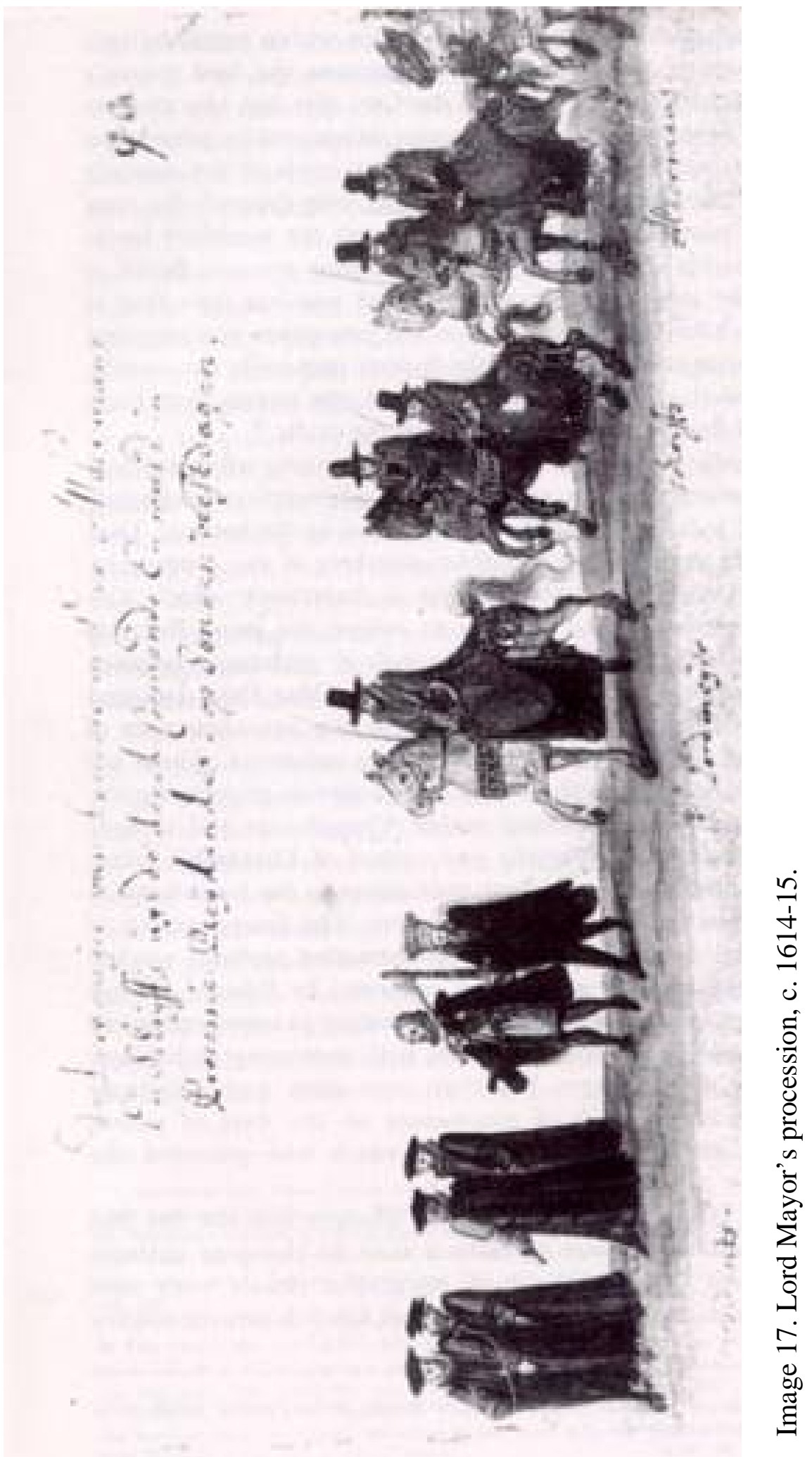


Next to him is the town common crier with his great mace. These individuals and their accoutrements can be identified by the detailed description provided by William Smythe, a citizen and haberdasher of London. ${ }^{33}$ What is interesting to note is that Smythe's account of the procession was written in 1575, roughly forty years before the Lord Mayor's show commemorated in the picture, and yet it clearly identifies exactly what we see presented. Before the sword bearer and the crier walk the liverymen in black gowns, wearing ruffs and black caps. It comes as no surprise that the Lord Mayor appears in the center of the picture, for the day's celebration is in his honor, but it must be noted that in the procession, he and his aldermen brethren came last. Before them marched the rest of London society.

Observing the procession in 1617, Busino notes that the triumph of the Lord Mayor begins with the City Marshall on horseback and two footmen in livery who try to clear the way, aided by "lusty youths" and men armed with long fencing swords. There were also men masked as "wild giants." Such characters, including devils and green-men, figure frequently in other accounts of the Lord Mayor's processions. Behind these men appeared the pageant wagons, which impressed Busino with their splendor, and he refers to them as a "triumphant fleet," but he makes no mention of speeches or dialogue. He does, however, mention the confections, sugar, nutmegs, dates and ginger which were thrown from one of the wagons into the surrounding

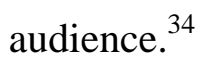

After the pageants, marched forty gentlemen wearing chains. Then came the Archbishop of Canterbury on horseback with the chief baron riding at his side. Next were mace-bearers, footmen, and other officers in tabards (short, sleeveless coats or 
jerkins) of black velvet, many of which were embroidered with the rose of England. Then followed earls, marquises, and other lords and treasurers of the kingdom. After the noblemen, there was a display of banners belonging to the Grocers' Company, one so large that it had to be carried by as many as six men, who supported it with staffs that connected to the one main staff. These were followed by fifty old men, all wearing long gowns of blue cloth with red sleeves and caps. These men carried javelins, and at night they carried the torches that lit the mayor's way back to his house. Behind them came a tall man wearing a large hat of squirrel's fur, the size of a basket, and holding a gilt truncheon (ceremonial staff).With him were two small children, "gaily dressed.” Finally, there appeared the Lord Mayor, the aldermen, and the sheriffs. Busino additionally notes that along the side of the road stood over a thousand gownsmen from the Lord Mayor's guild, the Grocers. They wore black gowns and had hoods over their left shoulder which were half red and half black. ${ }^{35}$ Busino's description of the final group differs slightly from what appears in the picture. For instance, there are no children in the picture. Also, Busino states that behind the Lord Mayor rode fifteen or twenty aldermen, with the two sheriffs in the rear. In the picture, this order is reversed, with the sheriffs appearing immediately after the mayor, followed by the aldermen. Finally, the liverymen appear in front of the Lord Mayor in the picture but are not even mentioned in Busino's description of the procession. This is likely an accidental omission since the day served to honor the Lord Mayor and his guild which paid for the day's events. The liverymen probably carried most of the burden of this cost and were not likely to be excluded from taking part in the event. Also, the liverymen figure importantly in descriptions of other Lord 
Mayor's processions. Smythe notes in 1575 that the liverymen appeared in long black gowns with half red, half black hoods on their left shoulders. It is possible that in 1617, the liverymen stood on the side of the road since the clothes that Busino notes on the guildsmen lining the streets are identical to those which Smythe sees on the liverymen in the procession.

However, Smythe also mentions other features of the Lord Mayor's progress that do not appear in Busino's discussion but were likely present: flying standards of the city and of the mayor's company; banners of the king's arms and the mayor's arms; and the sword bearer and the common crier carrying his mace. Smythe further notes that there were between sixty and a hundred bachelors, young guild members who were not yet liverymen, marching two and two together wearing long gowns with crimson hoods. Surviving guild records document the cost of apparel for bachelors throughout the period, suggesting that they also took part in the procession and were simply overlooked in the account. ${ }^{36}$

One group appearing in Busino's description can be found in Smythe's under a different name. Busino's old men in gowns of blue with red sleeves and caps are referred to by Smythe as poor men. In the guild records, "poor men" is the common term employed for the men chosen to receive free clothing and take part in the procession. ${ }^{37}$ As many as seventy poor men were annually provided for in the Lord Mayor's procession at considerable expense. ${ }^{38}$ In a series of engravings from the 1635 Lord Mayor's Day, there are printed illustrations presenting the four ages of life. The last is old age, which presents a man who, the appended verse tells us, has spent all of his money and must be cared for by others. ${ }^{39}$ The man presented appears 
in a robe and cap, and carries a torch in the same way that the poor men carried torches to light the way for the Lord Mayor at night.

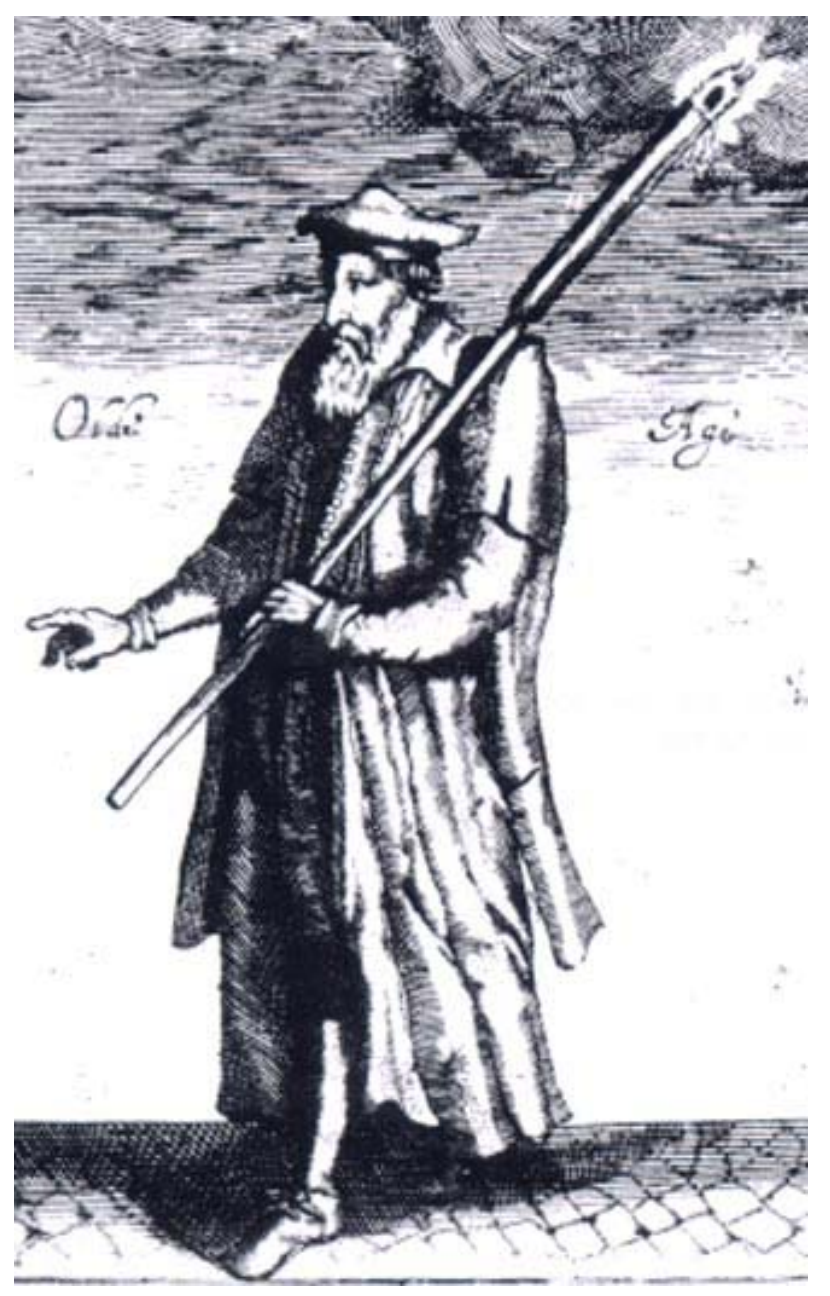

Image 18. The figure of Old Age in a 1635 print from the Lord Mayor's Show. ${ }^{40}$

John Astington notes in his study of these prints that the Lord Mayor's show, which began and ended at the same place, the Lord Mayor's house, provided a temporal context for the four pictures which show the journey of one's life from childhood to old age. ${ }^{41}$ For the purpose of this study, the pictures are most important for providing 
a contemporary image that likely corresponds to the manner in which individuals in the annual event actually appeared. And yet, such prints must be used cautiously since the information they present is not self-evident. The usefulness of the 1635 prints is determined by the fact that the visually based information they provide can be corroborated by contemporary report. This becomes apparent in the other characters presented in the prints.

In addition to providing an image of the poor men in the Lord Mayor's show, the prints likewise include an image of a youth (image 19) who is described as a whiffler, and a man (image 20) who, the poem informs us, has earned his livery gown. The whiffler appears in the fashionable clothes of the 1630s, wearing a doublet with paned sleeves, a wide falling collar, a Cavalier hat, and a full mustache. These articles of apparel do not serve to immediately identify one as a whiffler. The staff he holds suggests his office, for provision is made in guild record for the purchase of whiffler's staffs, and we can perhaps accept the word of the poetry that accompanies the print, but the young man's clothes merely highlight his ability to afford such finery - they do not provide a model for understanding how all, or even many, of the whifflers appeared. An explanation for this might lie in Busino’s description. There, he notes a number of "lusty youths and men armed with long fencing swords" who kept the crowds back. Thus, the whifflers may have typically dressed in fashionable clothes, but not in specific uniforms that identified the wearer. 


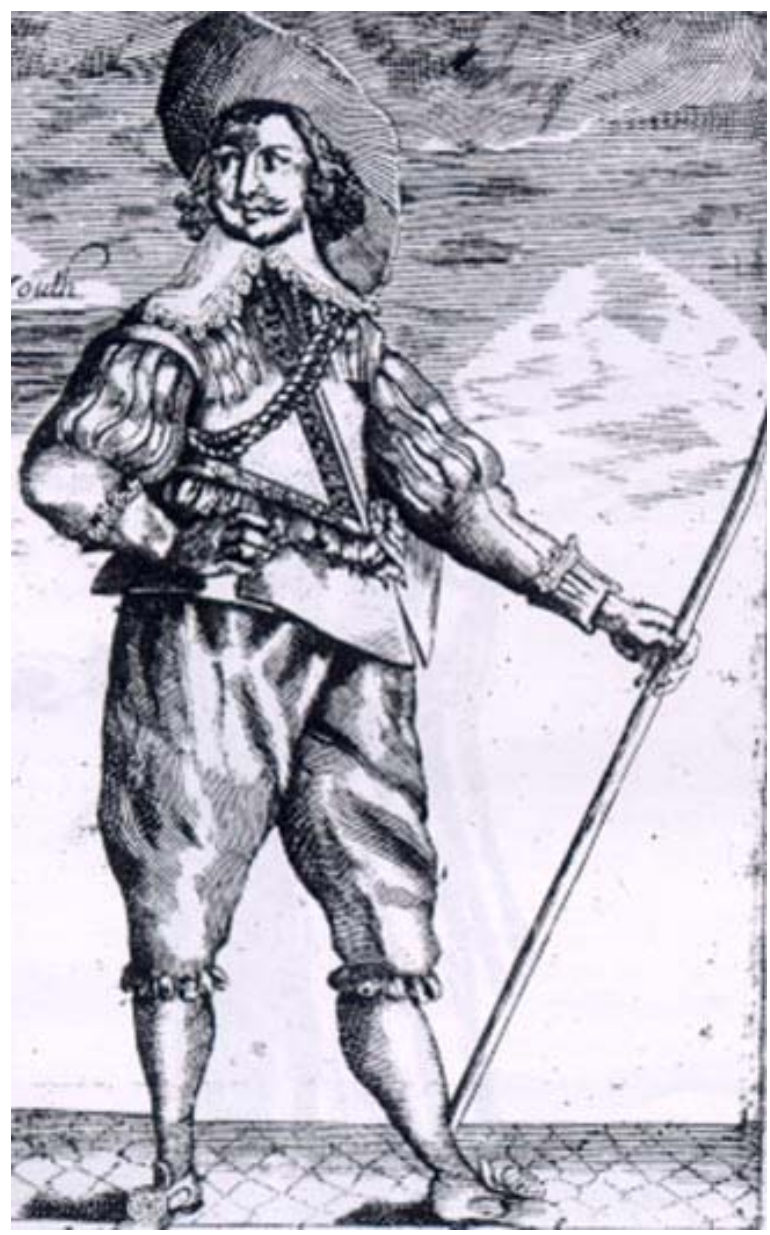

Image 19. Youth. ${ }^{42}$

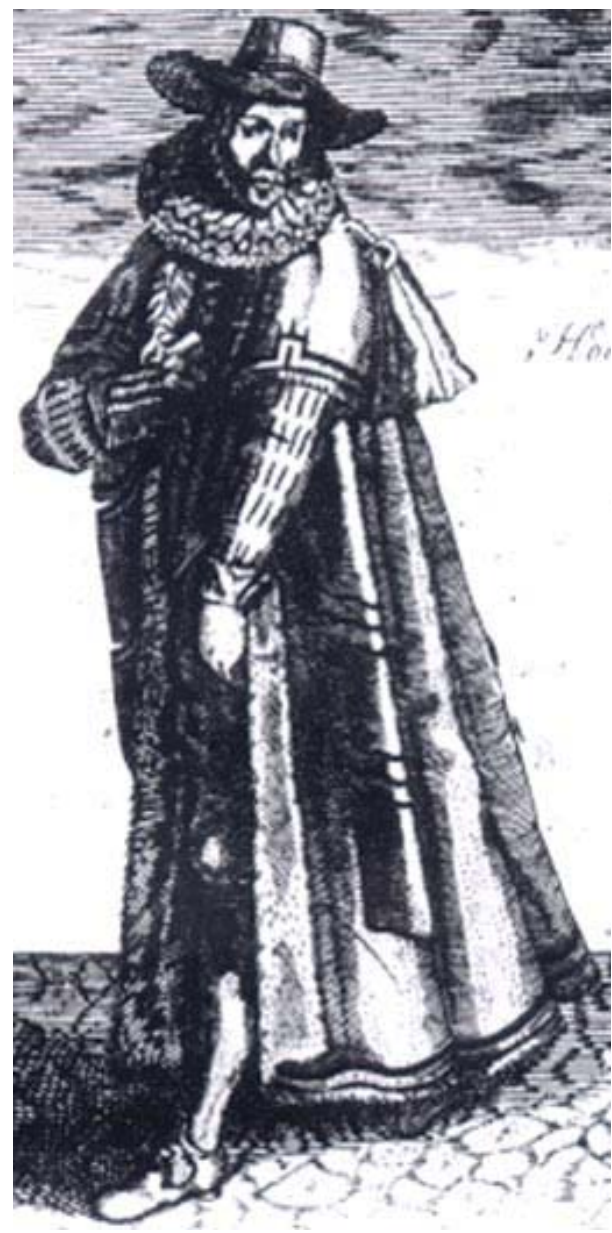

Image 20. Manhood. ${ }^{43}$

The liveryman, on the other hand, appears in the robes that denote his status as a guild leader. And yet, the light color of the apparel suggests that they are intended to be understood as scarlet. Perhaps this character is not just a liveryman, but a sheriff. The poetry notes that this person will "trott” in rank and file to St. Paul's Cathedral. The extant commentary from the period mentions the liverymen walking in the procession; only the mayor, the aldermen, and the sheriffs are on horseback. Furthermore, it was the responsibility of the new mayor and the sheriffs to pay for the enormous banquet held on the Lord Mayor's day, which is in accordance with the 
verse that accompanies the picture: "to feed high [I] spare nether cost nor charges." The absence of a gold chain around his neck shows that he is not, and has never been, Lord Mayor. All sheriffs were first, and remained, guild liverymen, so the verse is not wrong, but there is more to see in the picture than the lines suggest.

The parade that wound through the streets of London was populated by the entirety of London society, from poor men to noblemen, accompanied by music and fanfare, green-men and devils. Appearing on horseback at the end of the long procession, the Lord Mayor, the aldermen, and the sheriffs punctuated the festive nature of the triumph with their scarlet dignity. In this way, the parade, consisting of the highest and lowest members of society, served visually to legitimize the Lord Mayor's authority over those appearing in the procession by having them march ahead of the city officials in the manner of a Roman triumph. Dekker highlights this widely understood association in his introduction to the printed copy of the 1628 Lord Mayor's show Brittannia's Honor. There he states that the mayors of London were transformed on October 29 into Roman "triumphators," for "The Praetorian Dignity is therefore come from the ancient Roman, to inuest with Robes of Honor, our Lord Maior of London: Their Consuls are our Sheriefes: their Senators our Aldermen.” ${ }^{25}$

This legitimacy was further supported by the stops made during the progress. The first was at Westminster, as has already been noted, where the Lord Mayor's political power was recognized as flowing from the crown. It is no coincidence that the colors that dominate the Lord Mayor's procession are blue and scarlet. These colors, widely understood as representative of the city and the court, ${ }^{46}$ constitute a 
visually based narrative of amity and stability between the guilds and the monarch when displayed in the ordered progress that passes through the city.

Returning along the Thames, the next stop was at Guildhall where the economic preeminence of the Lord Mayor and the guilds was not only legitimized but celebrated by an enormous feast at the expense of the mayor and the sheriffs. William Smythe writes in 1575 that a thousand people attended the banquet, and that the cost reached $£ 400$; the Mayor paid $£ 200$ and each of the sheriffs $£ 100 .{ }^{47}$ The procession then went to St. Pauls for evening services. The practice of ceremonially including a religious rite in what is otherwise a secular celebration serves to blur the distinction between the two and invest the individual being honored with the authority afforded by both the church and the state. As Theodore Leinwand notes, the "fusion of wealth, trade, religion, and power is a paradigm for the special process of legitimation at work in all the Lord Mayors’ shows.”48

The increased number of pageant wagons that became the norm starting in 1605 can be understood to fit within this formulation of the Lord Mayor's show. For the vast majority of those who turned out for the Lord Mayor's Day, the pageants were spectacular elements of the procession, not dramatic ones. As was noted above, few would have been able to see more than one of the performances, and even fewer would have been able to hear them. However, everyone would have had a chance to see them as they were pulled along through the streets of London in the procession. As part of the parade, the pageant wagons served three purposes: (1) they identified the guild and the new Lord Mayor sponsoring the show through easily decipherable images, (2) they provided appropriate venues for the characters who presented 
speeches before the Lord Mayor, and (3) they demonstrated the magnificence of the guild through their size and splendor. Even though designs exist for only one Lord Mayor's day show, Anthony Munday’s 1616 show for the fishmongers, each of these purposes can be clearly identified among them. ${ }^{49}$

The first purpose, identifying the sponsoring guild and the Lord Mayor, can be seen in the first pageant which appeared as a fishing boat. The pageant would leave no doubt in anyone's mind as to whose guild was presenting the show. In the printed text of the show, Munday writes that the people on the pageant will actually draw up nets filled with live fish and pass them to spectators watching the performance. ${ }^{50}$

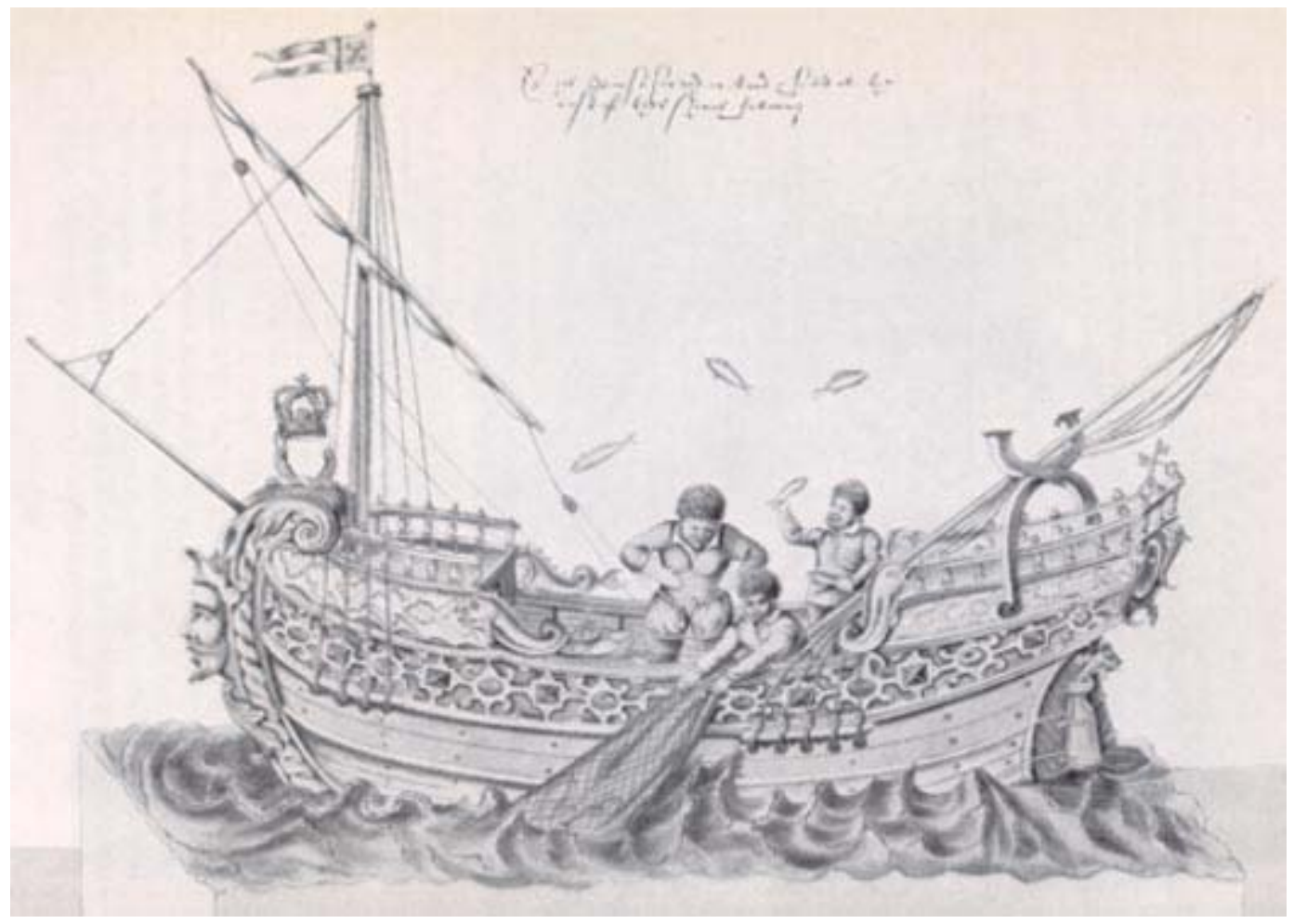

Image 21. Fishing boat device in 1616 Lord Mayor's Show. ${ }^{51}$ 
Another pageant for which we have a design presents a lemon tree and a pelican feeding its young with its own blood. Here, the meaning would be plain to an early modern audience. The lemon tree is a pun on the new Lord Mayor's name, John Leman (this sort of humor was common in the shows). The pelican represents the magnanimity of the new mayor who would nourish London and see it grow even by feeding it from his own blood.

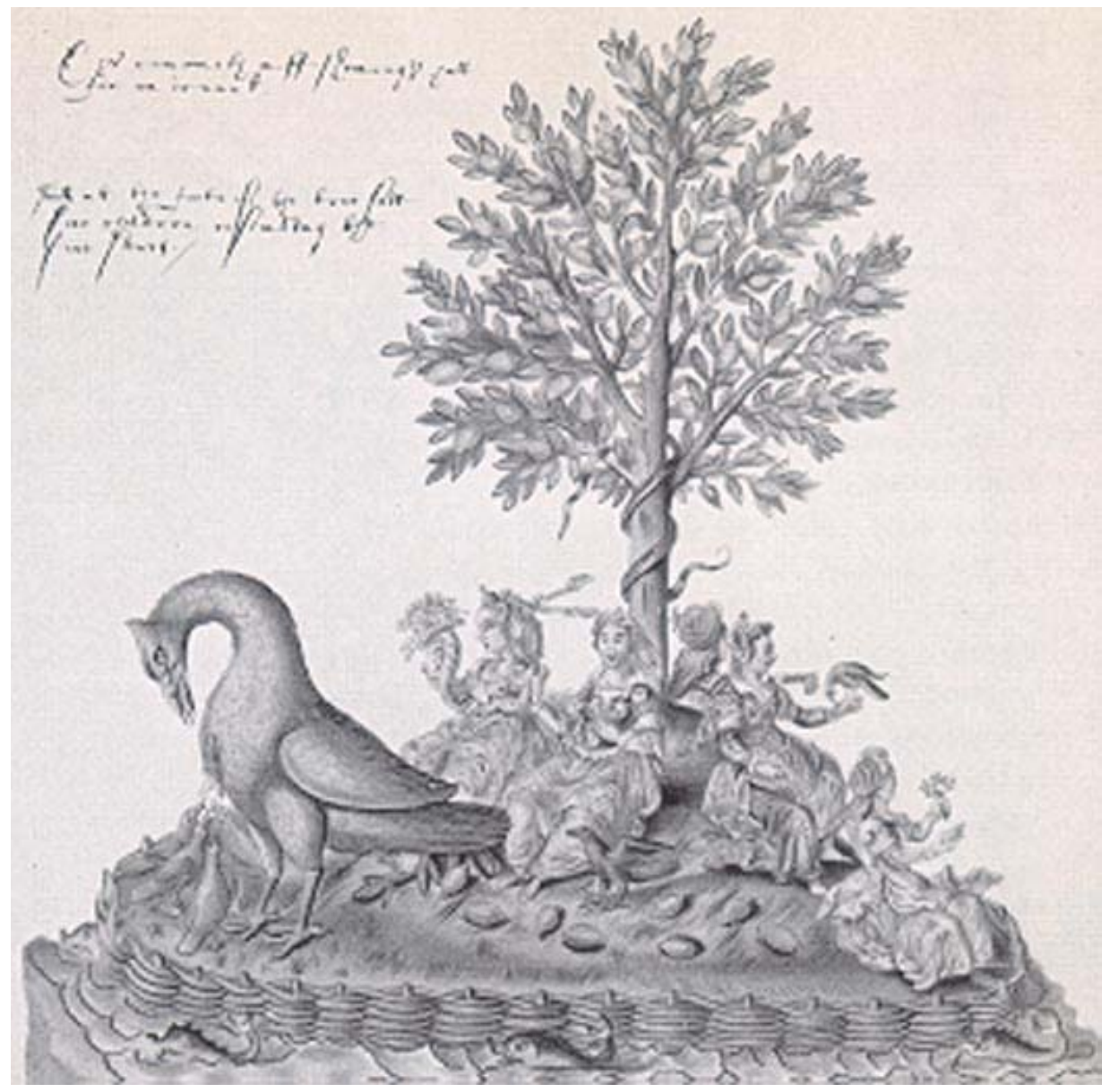

Image 22. Lemon tree and Pelican device in 1616 Lord Mayor's Show. $^{52}$ 
The manner in which the wagons served their second purpose, as appropriate venues for the presentation of speeches in honor of the newly elected official and his guild, has been the focus of numerous studies of the Lord Mayor's show and need not be discussed here. ${ }^{53}$

The third purpose of the pageant wagons, to demonstrate the magnificence of the guild being honored, prompted the enormous sums of money that were paid annually to build them. Glynne Wickham notes that taxes were levied on all the wards of the city to raise the $£ 7873$ s. 4 d. spent on James I's reception in $1603 .^{54}$ The costs of the Lord Mayor's shows, on the other hand, were paid for entirely by the sponsoring guild and the fee was sometimes even higher than what the city paid for the arrival of the King. In 1605, the Merchant Taylors paid £710. 2s. 5d. for their show. In 1612, the Merchant Taylors paid the incredible price of £978. 12s. 11d. for their show. Then, in 1624, the Merchant Taylors paid £1099. 5s. 11d. This appears to be the highest price paid for a Lord Mayor's Show before the interregnum when they were discontinued. None of the other guilds in Stuart London could compete with the expenditures of the Merchant Taylors, but few of them went below $£ 500$ for a show and many passed $£ 700$.

When drawn through the streets of London, the pageant wagons served much the same function in the Lord Mayor's Day procession as the apparel worn by the Lord Mayor and his entourage. They identified the guild membership of the new Lord Mayor and reaffirmed his right to govern London. The new Lord Mayor was typically drawn from one of the twelve great chartered companies: the Mercers, the Grocers, the Drapers, the Fishmongers, the Goldsmiths, the Skinners, the Merchant Tailors, the 
Haberdashers, the Salters, the Ironmongers, the Vintners, and the Clothworkers. Having a member of one's company become Lord Mayor was a source of pride for a guild. Consequently, the pageant wagons highlighted the new official's guild membership for all those who saw them.

The lavish amounts of money expended on the pageants served to interpolate the growing wealth of the guilds into the process of legitimation whereby the Lord Mayor and the aldermen were accepted as the rightful rulers of London. Cheering the lavish procession and catching candy and fish thrown from the pageant wagons, bystanders were encouraged to accept the financial authority of the new Lord Mayor who was honored by the event. Taken together, the spectacular public presentation of the Lord Mayor's costumed procession and the path that it followed through the city served as a social drama in which the financial, political, and social control of the Guilds over London was identified as sanctioned by the crown, blessed by God, and exercised to the benefit of the Kingdom. 


\section{CONCLUSION}

At the opening of his book, Shakespearean Negotiations, Stephen Greenblatt declares the ambitious goal that drives his examination of early modern English literature and theatre: "I began with a desire to speak with the dead."1 This dissertation pursues a related goal: I began with a desire to see the dead. I wanted to know how performers appeared when they walked onto English stages four hundred years ago. What clothes did Edward Alleyn wear when he issued forth Marlowe's mighty line? How did Burbage dress when he personated Hamlet’s “antic disposition”? How did boys appear when they played the roles of women?

Beyond merely drawing on Greenblatt's bold wording, however, this dissertation also takes part in and extends the methodological approach that he brought to early modern literary studies in $1980 .^{2}$ A major argument of new historicism holds that in England in the late sixteenth and early seventeenth centuries, one’s identity was not a static concept: it did not remain fixed and unchanging over time. Rather, it was malleable, being continually produced through an individual's public performance of self-hood. One of the primary ways by which people asserted their identities in early modern England was through the wearing of apparel.

In 1983, Lisa Jardine acknowledged the importance of apparel to selffashioning and pursued a new historical study of gender by examining the practice of 
cross-dressing on the early modern stage. She noted that anti-theatrical tracts responded frequently and heatedly to the stage practice of having boys play women's roles. Following her lead, Laura Levine, Phyllis Rackin, Jean Howard, Jonathan Dollimore, and Stephen Orgel expanded and refined this study into a vibrant field of historical inquiry. As Orgel explains, "clothes make the woman, clothes make the man: the costume is of the essence.”’3

Beyond considering issues of gender and cross-dressing, recent new historical scholarship has also engaged the broader role that clothing played in early modern England. Ann Rosalind Jones and Peter Stallybrass have written extensively on the importance of apparel in the period. They argue that clothes served a double purpose at the time, operating both as a means of establishing self-hood and as a form of cultural capital that was regularly borrowed, traded, and translated. They further argue that clothes were crucial to early modern English drama, marking the extensive engagement that the theatre companies had with the clothing industry.

Building on these new historical considerations of costume and clothing in early modern England, this dissertation focuses on the visual codes that maintained in the period. For instance, it has been well established that the theatres used costumes to mark the gender of the characters on stage. My study determines how this was visually accomplished. What articles of apparel did actors wear to assume the role of women? And, more importantly, how did those choices influence the meaning produced in performance? In pursuing the answers to these questions, this dissertation brings to new historicism some of the strengths of traditional theatre history. 
Costume historians like Herbert Norris, Graham Reynolds, and Phillis Cunnington have devoted considerable effort to enumerating the fashions and apparel that were worn in England during the late sixteenth and early seventeenth century. My dissertation notes the relevance of this scholarship to cultural analyses of the period by identifying in it the sartorial signifiers of sex and gender, social class, occupation, nationality, and religion that maintained at the time. What becomes clear is that the early modern English theatre had a complex visual vocabulary that was widely understood by many who attended the theatre and was cunningly employed by those who wrote and performed the plays.

Moreover, by examining court masques and Lord Mayor's Shows in addition to the professional stages, this dissertation differentiates the ways that costumes were employed in the various theatrical venues. Engaging the work of scholars such as Roy Strong and Stephen Orgel, I have pursued further the intersection between apparel and iconography in the Stuart masques to better understand the complex and overlapping sites at which power was localized in the elite entertainments. My study of the apparel worn in the Lord Mayor's Shows ultimately suggests that scholarly attention should be shifted from the dramatic dialogues, which have heretofore dominated considerations of the event, to the visual spectacle of the processions that established and celebrated the power of the newly elected official.

In the last few years, the importance of apparel to studies of early modern English theatre and culture has become widely acknowledged. Indeed, in his recently published introduction to Shakespearean drama, Arthur Kinney devotes roughly as much attention to costumes and properties as he does to the period's stages or actors. ${ }^{4}$ 
And he is right to do so, for, as Fernand Braudel states in Capitalism and Material Life 1400-1800, the history of clothing "touches on every issue-raw materials, production processes, manufacturing costs, cultural stability, fashion and social hierarchy.," In "Costuming the Shakespearean Stage," I have sought to bring to early modern studies a consideration of the visual codes that maintained in England and an analysis of the ways they were employed in theatrical and cultural performances. 


\section{ENDNOTES}

\section{NOTES TO INTRODUCTION}

${ }^{1}$ Qtd. in Wilfred Hooper, “The Tudor Sumptuary Laws,” The English Historical Review 69 (1915): 443.

2 Ibid, 441.

${ }^{3}$ Ann Rosalind Jones and Peter Stallybrass, Renaissance Clothing and the Materials of Memory (New York: Cambridge University Press, 2000), 188.

4 “Godly Queene Hester,” English Verse Drama, 1994, <http://www.ohiolink.edu/cgi-bin/evd-entries.pl?PLAY+81279083> (8 June 2003).

5 Jean MacIntyre, Costumes and Scripts in the Elizabethan Theatres (Edmonton: The University of Alberta Press, 1992), 29-37.

${ }^{6}$ Lisa Jardine, Still Harping on Daughters (Totowa, N.J.: Barnes \& Noble, 1983), Laura Levine, Men in Women's Clothing: Anti-Theatricality and Effeminization (New York: Cambridge University Press, 1994), Jean E. Howard, "Cross-Dressing, the Theater, and Gender Struggle in Early Modern England," in Crossing the Stage: Controversies on Cross-dressing, ed. Lesley Ferris (New York: Routledge, 1993), and Stephen Orgel, Impersonations: The Performance of Gender in Shakespeare's England (New York: Cambridge University Press, 1996).

${ }^{7}$ Ann Rosalind Jones, "Dematerializations: Textile and Textual Properties in Ovid, Sandys, and Spencer," in Subject and Object in Renaissance Culture, edited by Margreta de Grazia, Maureen Quilligan, and Peter Stallybrass (Cambridge: Cambridge University Press, 1996), 189-212. Peter Stallybrass, "Patriarchal Territories: The Body Enclosed,” in Rewriting the Renaissance, edited by M. Ferguson, M. Quilligan, and N. J. Vickers (Chicago: University of Chicago Press, 1986), 123-42. Peter Stallybrass, "Worn Worlds: Clothes and Identity on the Renaissance Stage," in Subject and Object in Renaissance Culture, edited by M. De Grazia, M. Quilligan, and P. Stallybrass (Cambridge: Cambridge University Press, 1996), 289-320. Peter Stallybrass, "Worn Worlds: Clothes, Mourning, and the Life of Things," in Cultural Memory and the Construction of Identity, edited by Dan BenAmos and Liliane Weissberg (Detroit: Wayne State University Press, 1999), 27-44. Ann Rosalind Jones and Peter Stallybrass, Renaissance Clothing and the Materials of Memory (New York: Cambridge University Press, 2000). 
${ }^{8}$ My Shakespeare references are to The Riverside Shakespeare, $2^{\text {nd }}$ ed. ed. G. Blakemore Evans with the assistance of J. J. M. Tobin (Boston and New York: Houghton Mifflin, 1997).

${ }^{9} \mathrm{Hal} \mathrm{H}$. Smith argues that these productions were costumed "in the classic manner as the Renaissance understood it," by which he means that they were essentially modified Elizabethan dress. "Some Principles of Elizabethan Stage Costume,” Journal of the Warburg and Courtald Institutes 25 (1962): 240-57.

${ }^{10}$ Ever since E. K. Chambers published this drawing in 1925, it has been surmised that it depicts Shakespeare's Titus Andronicus. More recently, June Schlueter has argued that it is, in fact, drawn from a play performed in Germany by English actors that translates to A Very Lamentable Tragedy of Titus Andronicus and the Haughty Empress. E. K. Chambers, “The First Illustration to 'Shakespeare,"” The Library, $4^{\text {th }}$ ser., 5 (1925): 326-30. June Schlueter, "Reading the Peacham Drawing," Shakespeare Quarterly 50 (1999): 171-84.

${ }^{11}$ Picture drawn from R. A. Foakes, Illustrations of the English Stage, 15801642 (London: Scolar, 1985), 47.

\section{NOTES TO CHAPTER 1}

${ }^{1}$ G. K. Hunter, "Flatcaps and Bluecoats: Visual Signals on the Elizabethan Stage,” Essays and Studies 33 (1980): 28.

2 Graham Reynolds, “Elizabethan and Jacobean: 1558-1625,” in Costume of the Western World ed. James Laver (New York: Harper and Brothers, 1951), 131.

${ }^{3}$ For a more extensive consideration of individual articles of clothing, the different fabrics from which they could be made, and references made to them in early modern drama, one should look to M. Channing Linthicum's Costume in the Drama of Shakespeare and his Contemporaries. Although published in 1936, Linthicum's book remains a treasure trove of historical scholarship. For more specific fashion trends, particularly in court clothing, see C. Willett Cunnington and Phillis Cunnington's Handbook of English Costume in the Seventeenth Century (London: Faber and Faber, 1955).

${ }^{4}$ Special thanks to Adam West for this drawing.

${ }^{5}$ M. Channing Linthicum, Costume in the Drama of Shakespeare and His Contemporaries (Oxford: Clarendon Press, 1936), 199.

${ }^{6}$ Special thanks to Adam West for this drawing. 
${ }^{7}$ Reynolds, 132.

${ }^{8}$ Reynolds, 132.

${ }^{9}$ There were various kinds of starch which were of a variety of colors and textures. For a study of starch and the particular significance of yellow starch, see Ann Rosalind Jones and Peter Stallybrass, chapter 3.

${ }^{10}$ Ben Jonson, The Alchemist in Three Comedies, ed. Michael Jamieson (New York: Penguin, 1966).

${ }^{11}$ James Laver, The Concise History of Costume and Fashion (New York: Harry N. Abrams, 1969), 91.

12 Reynolds, 132.

13 Thomas Dekker, II The Honest Whore, in The Chief Elizabethan Dramatists, ed. William Allan Neilson (Boston and New York: Houghton Mifflin, 1911), 425-55.

${ }^{14}$ Andrew Gurr, The Shakespearean Stage, $3^{\text {rd }}$ ed. (New York: Cambridge University Press, 1992), 1-2.

${ }^{15}$ Special thanks to Adam West for this drawing.

${ }^{16}$ Reynolds, 134.

${ }^{17}$ Linthicum, Costume, 181. Lithicum states that the style of the drum farthingale originated in Italy, 181. C. Willett Cunnington and Phillis Cunnington state that the style originated in France, Handbook of English Costume in the Seventeenth Century (London: Faber and Faber), 87. Neither presents convincing evidence to determine which origin is more likely.

${ }^{18}$ Special thanks to Adam West for this drawing.

${ }^{19}$ Linthicum, Costume, 182.

${ }^{20}$ Cunnington, Handbook, 99.

${ }^{21}$ Reynolds, 134.

${ }^{22}$ Reynolds, 134.

${ }^{23}$ Stephen Orgel, Impersonations: The Performance of Gender in Shakespeare's England (New York: Cambridge University Press, 1996), 5-6. 
${ }^{24}$ Qtd. in Orgel 83.

${ }^{25}$ William Prynne, The Unlovelinesse of Lovelockes (London, 1628), i.

${ }^{26}$ I do not mean to suggest that the audience did not know, at least on some level, that the person underneath the costume was male. No doubt they did. However, I want to piece together what they saw and how they saw it in order to understand better the tacit agreement between the audience and the actors as to what was allowable and what was expected on stage. As Joy Leslie Gibson explains: "The actors and the audience are also colluding with the writer, to believe in his vision and, thus, to make something greater than what is actually on the page." Squeaking Cleopatras: The Elizabethan Boy Player (Phoenix Mill: Sutton Publishing, 2000), 189. I am most interested in exploring this collusion which determines how the play existed at a particular time in history.

${ }^{27}$ Michael Shapiro notes that the members of a children's troupe ranged in age from ten to fifteen in Children of the Revels: The Boy Companies of Shakespeare's Time and Their Plays (New York: Columbia University Press, 1977), 104.

${ }^{28}$ Will Fisher, "The Renaissance Beard: Masculinity in Early Modern England,” Renaissance Quarterly 54 (2001), 157.

${ }^{29}$ All of the references to codpieces I have found in the drama are satirical references to an outdated style.

${ }^{30}$ Fisher, 158, 163, 180.

${ }^{31}$ It strikes me that the manner in which masculinity and femininity are visually depicted in early modern England supports the one sex model. It makes sense that a woman is an incomplete man if she can imitate him by simply adding the accoutrements that depict masculinity, e.g., the clothing, the beard, the sword. Accordingly, it would be difficult for a man to imitate a woman since he cannot readily doff the beard that materializes his masculinity. For a discussion of the one sex model, see Stephen Orgel's Impersonations: The Performance of Gender in Shakespeare's England (New York: Cambridge University Press, 1996), chapter 2.

${ }^{32}$ Fisher, 175.

${ }^{33}$ Picture drawn from Ruth Samson Luborsky and Elizabeth Morley Ingram, A Guide to English Illustrated Books, 1536-1603 (Tempe, Arizona: Medieval \& Renaissance Texts \& Studies: 1998), 216, image 166. 
${ }^{34}$ Gurr cites Sir Thomas Smith and William Harrison for these four classes but notes that this division, based as it is upon land ownership, was how social stratification was widely understood at the time, Playgoing in Shakespeare's London (New York: Cambridge University Press, 1987), 49-50.

${ }^{35}$ Qtd. in Frances Elizabeth Baldwin, Sumptuary Legislation and Personal Regulation in England (Baltimore: The Johns Hopkins University Press, 1926), 222.

${ }^{36}$ Phillip Stubbes's Anatomy of the Abuses in England in Shakespeare's Youth, A.D. 1583 ed. Frederick J. Furnivall (London: N. Trubner, 1877-9), 34.

${ }^{37}$ Hic Mulier: or, the Man-Woman (London, 1620), sig. C1v.

${ }^{38}$ William Prynne, The Unlovelinesse of Lovelockes, iv-v.

39 “'Cloathes Worth All the Rest': Costumes and Properties," in A New History of Early English Drama ed. John D. Cox and David Scott Kastan (New York: Columbia University Press, 1997), 270.

${ }^{40}$ MacIntyre and Epp, 270. Additionally, it is important to note that the absence of sumptuary laws after 1604 did not result from a general belief that people should be allowed to choose their clothing as they please. Rather, new legislation failed to pass as a consequence of the political conflict between the Stuart monarchs, James I and Charles I, and their parliaments. Both kings sought to regulate dress by royal proclamation and both were unsuccessful due to parliament's refusal to encourage the absolutist policy whereby control over clothing would be located entirely in the hands of the monarch (per the workings of royal proclamations). See Reed Benhamou, "The Restraint of Excessive Apparel: England 1337-1604” in Dress 15 (1989), 32 and Baldwin, 258-60, 263.

${ }^{41}$ Qtd. in Baldwin, 218. Herbert Norris defines jenet as "the fur of a horse in black and in grey,” 370. Norris defines Luzarnes [sic] as fur from the Russian lynx: "The European kind was usually a dark grey, tinted with tawny orange; and variegated with dark spots and patches. The lynx of Asia and Africa was of a yellowish grey colour, and this fur was highly valued," 130. By "knyghtes or thorder," the statute may have meant the order of the garter which was often exempt from rules governing other knights. Herbert Norris, Tudor Costume and Fashion (New York: Dover, 1997), 539. This volume is an unabridged reissuing of books one and two of Norris's Costume and Fashion, Volume Three: The Tudors (London: J. M. Dent and Sons Ltd., 1938).

${ }^{42}$ Baldwin, 219. Chamlet was a soft, fine fabric made in Syria, Asia Minor, India, and Tibet, of the hair of chamois, Linthicum, Costume, 73. I am uncertain what 
libardes and bodge are although the former may have been leopards whose fur was employed in clothing in the period.

${ }^{43}$ This is drawn from Baldwin, 228-9.

${ }^{44}$ Thomas Dekker, The Guls Horne-booke (London, 1609), 28-9.

${ }^{45}$ Jones and Stallybrass, 190-1.

46 Jones and Stallybrass, 190.

${ }^{47}$ Hunter, 32; Jones and Stallybrass, 198.

${ }^{48}$ Baldwin, 231-2.

${ }^{49}$ Phillis Cunnington and Catherine Lucas note that "the blackness of cobblers' and tinkers' aprons were so characteristic that a man in a black apron would be recognized for one of them at once," Occupational Costume in England: From the Eleventh Century to 1914 (New York: Barnes and Noble, 1967), 375.

50 Thomas Dekker, The Shoemaker's Holiday, ed. Anthony Parr (New York: Norton, 1990), 7.104.

${ }^{51}$ The picture appears in Valerie Hope, My Lord Mayor: Eight Hundred Years of London's Mayoralty (London: Weidenfeld and Nicolson, 1989, 52-3.

52 Phillis Cunnington, Costume of Household Servants from the Middle Ages to 1900 (London: Adam and Charles Black, 1974), 17.

53 “There’s more true honesty in such a country serving-man than in a hundred of our cloak companions; I may well call 'em companions, for since blue coats have turn'd into cloaks, we can scarce know the man from the master." Thomas Middleton, A Trick To Catch the Old One in Thomas Middleton: Five Plays, ed. Bryan Loughrey and Neil Taylor (New York: Penguin, 1988), 1.2.133-6. This quote suggests that livery practices were changing at the time from having servants wear blue coats to having them wear blue cloaks.

${ }^{54}$ For King James’ progress through London at the beginning of his reign, the actors of the newly appointed King's Men were each given four and a half yards of scarlet for livery.

${ }^{55}$ Cunnington and Lucas, 22.

${ }^{56}$ Cunnington and Lucas, 27. 
${ }^{57}$ Brian Reade, “The Dominance of Spain,” Costume of the Western World, ed. James Laver (New York: Harber \& Brothers, 1951), 191.

${ }^{58}$ F. M. Kelly, Shakespearian Costume Revised by Alan Mansfield (New York: Theatre Arts Books, 1970), 61.

${ }^{59}$ Ben Jonson, Five Plays, ed. G. A. Wilkes (New York: Oxford University Press, 1988).

${ }^{60}$ For an excellent study of Jews in England and in the early modern imagination, see James Shapiro, Shakespeare and the Jews (New York: Columbia University Press, 1996).

${ }^{61}$ M. Channing Linthicum, “My Jewish Gaberdine,” PMLA 43 (1928): 75766.

${ }^{62}$ Cumberland Clark, Shakespeare and Costume (London: Mitre Press, 1937): 53.

${ }^{63}$ Linthicum, Costume, 201.

${ }^{64}$ Randall Nakayama, “'I know she is a courtesan by her attire’: Clothing and Identity in The Jew of Malta," in Marlowe's Empery: Expanding His Critical Contexts, eds. Sara Munson Deats and Robert A. Logan (Newark: University of Delaware Press, 2002), 161.

65 Patrick Collinson, "From Iconoclasm to Iconophobia: The Cultural Impact of the Second English Reformation," in The Impact of the English Reformation, 15001640, ed. Peter Marshall (New York: Arnold, 1997), 282.

${ }^{66}$ For examples, see Luborsky and Ingram, image 64, 69, 72.

${ }^{67}$ Luborsky and Ingram, image 69.

\section{NOTES TO CHAPTER 2}

${ }^{1}$ David Bevington and Peter Holbrook, eds. The Politics of the Stuart Court Masque (New York: Cambridge University Press, 1998), 16. The articles by Stephen Orgel and Leeds Barrol in this compilation actually belie this assertion, offering sophisticated engagements with the visual aesthetics. Nevertheless, the editors' desire to focus almost exclusively on other, decidedly literary, issues is made clear at the outset. 
${ }^{2}$ Stephen Greenblatt, Shakespearean Negotiations (Berkeley: University of California Press, 1988), 4. I am taking liberties with Greenblatt's intended meaning to demonstrate how New Historicism, despite its expanded focus of study, often remains tightly connected to literary studies.

${ }^{3}$ Stephen Orgel, ed., Ben Jonson: The Complete Masques (New Haven: Yale University Press, 1969), 75-6.

${ }^{4}$ Stephen Orgel and Roy Strong, Indigo Jones: The Theatre of the Stuart Court, 2 vol. (Berkeley: University of California Press), 2-3.

${ }^{5}$ Ben Jonson, Ben Jonson's Literary Criticism, ed. James D. Redwine, Jr. (Lincoln: University of Nebraska Press, 1970), 15.

${ }^{6}$ Orgel and Strong, 2-3.

${ }^{7}$ Keith Sturgess, Jacobean Private Theatre (New York: Routledge \& Kegan Paul, 1987).

${ }^{8}$ Allardyce Nicoll, Stuart Masques and the Renaissance Stage (New York: Benjamin Blom, 1938), 154.

${ }^{9}$ My versions are Cesare Ripa, Iconology, Selected by George Richardson, Intro. by Stephen Orgel (New York: Garland, 1979). Cesare Vecellio, Vecellio's Renaissance Costume Book: All 500 Woodcut Illustrations from the Famous Sixteenth-Century Compendium of World Costume (New York: Dover, 1977).

${ }^{10}$ Allan H. Gilbert, The Symbolic Persons in the Masques of Ben Jonson (Durham, NC: Duke University Press, 1948).

${ }^{11}$ M. Channing Linthicum, Costume in the Drama of Shakespeare and His Contemporaries (Oxford: Clarendon Press, 1936), 48.

${ }^{12}$ C. H. Herford Percy and Evelyn Simpson, ed., Ben Jonson, Vol. 10 (Oxford: Clarendon Press, 1954), 466.

${ }^{13}$ In the line notes that accompany the anti-masque to The Masque of Queens, Jonson argues that a poet must rely upon the audience's ability to comprehend the lines that are spoken. If a poet tries, instead, to have the characters explain the meaning of their lines, the work will be weakened.

For to have made themselves [the characters in the anti-masque] their own decipherers, and each one to have told upon their entrance what they were and whether they would [sic], had been a most piteous hearing, and utterly unworthy any quality of a poem, wherein a writer 
should always trust somewhat to the capacity of the spectator, especially at these spectacles, where men, beside inquiring eyes, are understood to bring quick ears, and not those sluggish ones of porters and mechanics that must be bored through at every act with narrations. And yet, like so many of the other masques, The Masque of Queens also adheres to the practice of introducing the characters when they enter, i.e., not trusting "to the capacity" of the spectators to recognize the characters and ideas being portrayed.

14 Nicoll, 155-6.

${ }^{15}$ Nicoll does not mention the fact that the character's identity is provided in the text of the masque.

${ }^{16}$ Stephen Orgel, The Illusion of Power: Political Theater in the English Renaissance (Berkeley: University of California Press), 24.

${ }^{17}$ Orgel and Strong, 46.

${ }^{18}$ Francis Bacon, The Essays or Covnsels, Civill and Morall: of Francis Lo. Verdam (London, 1639), 224-5.

${ }^{19}$ Robert Graves, Lighting the Shakespearean Stage, 1567-1642 (Carbondale and Edwardsville: Southern Illinois University Press, 1999), 171.

${ }^{20}$ Ibid.

${ }^{21}$ Jones and Strong, 145.

${ }^{22}$ Picture from Ogel and Strong, 147.

${ }^{23}$ Picture from Orgel and Strong, 616-7.

${ }^{24}$ Orgel and Strong, 439.

${ }^{25}$ Picture from Jones and Strong, 445.

${ }^{26}$ Stephen Orgel, "What is a Text," Research Opportunities in Renaissance Drama 26 (1981): 3-6.

${ }^{27}$ Stephen Orgel, "Marginal Jonson," in The Politics of the Stuart Court Masque, ed. David Bevington and Peter Holbrook (New York: Cambridge University Press, 1998), 153.

${ }^{28}$ Orgel and Strong, 43.

${ }^{29}$ Ibid. 
${ }^{30}$ Ibid, 383.

${ }^{31}$ This newfound control over the costumes fits with the ideological objectives that Jennifer Chibnall identifies in the Caroline masque: "The Caroline court masque represents a final gesture of a feudally based aristocracy which defined itself as the ultimate order of earthly achievement." “'To that secure fix'd state': The function of the Caroline masque form” in The Court Masque, ed. David Lindley (Manchester: Manchester University Press, 1984), 82.

${ }^{32}$ This is from the 1631 masque, Love's Triumph through Callipolis.

${ }^{33}$ Ibid, 570.

${ }^{34}$ Ibid, 43.

${ }^{35}$ Ben Jonson mentions the Queen's command in the commentary that accompanies The Masque of Queens, The Complete Masques, 12-14.

${ }^{36}$ Orgel and Strong, 43.

37 Sturgess, 196.

${ }^{38}$ Orgel, The Illusion of Power, 38

${ }^{39}$ Ibid, 39.

${ }^{40}$ Bacon, 225. Jonson similarly provides support for the notion that the costumes worn by the masquers onstage should demonstrate their status off. In his preface to Hymenaei, Jonson notes that although he wants to stress the importance of the masque's philosophical argument, the visual splendor of the masque is appropriate to the most elite members of society: "This it is hath made the most royal princes and greatest persons, who are commonly the personators of these actions, not only studious of riches and magnificence in the outward celebration or show, which rightly becomes them, but curious after the most high and hearty inventions to furnish the inward parts, and those grounded upon antiquity and solid learnings" (Orgel and Strong 106).

${ }^{41}$ Richard Halpern, The Poetics of Primitive Accumulation: English Renaissance Culture and the Genealogy of Capital (Ithaca: Cornell University Press, 1981), 3.

42 Bevington and Holbrook, 4.

${ }^{43}$ Orgel and Strong, 106. 
${ }^{44}$ Ibid, 131.

${ }^{45}$ Ibid, 242.

${ }^{46}$ Ibid, 282.

47 Ibid, 479.

48 Ibid, 570.

${ }^{49}$ My text is the Riverside Shakespeare. William Shakespeare, The Riverside Shakespeare $2^{\text {nd }}$ ed. (New York: Houghton Mifflin, 1997).

${ }^{50}$ Randall Nakayam, "'I know she is a courtesan by her attire’: Clothing and Identity in The Jew of Malta," in Marlowe's Empery: Expanding His Critical Contexts, ed. Sara Munson Deats and Robert A. Logan (Newark: University of Delaware Press, 2002), 152.

${ }^{51}$ Orgel, “Marginal Jonson,” 150.

${ }^{52}$ For a summation of New Historicism's engagement with the masque, see Bevington and Holbrook, 1-19.

${ }^{53}$ Martin Butler, “Courtly negotiations,” in The Politics of the Stuart Court Masque, ed. David Bevington and Peter Holbrook (New York: Cambridge University Press, 1998), 21.

${ }^{54}$ Leeds Barroll, Anna of Denmark, Queen of England: A Cultural Biography (Philadelphia: University of Pennsylvania Press, 2001), 97.

${ }^{55}$ Leeds Barrol, “Inventing the Stuart Masque,” in The Politics of the Stuart Court Masque, ed. David Bevington and Peter Holbrook (New York: Cambridge University Press, 1998), 126.

${ }^{56}$ Ibid., 122.

${ }^{57}$ Orgel, “Marginal Jonson,” 171.

${ }^{58}$ Stephen Orgel, “Jonson and the Amazons," in Soliciting Interpretation: Literary Theory and Seventeeth-Century English Poetry, ed. Elizabeth D. Harvey and Katherine Eisaman Maus (Chicago: University of Chicago Press, 1990), 128.

${ }^{59}$ Orgel and Strong, 89. 
${ }^{60}$ Qtd. in Gordon Kipling, “Triumphal Drama: Form in English Civic Pageantry,” Renaissance Drama n.s. 8 (1977): 41.

${ }^{61}$ Kim F. Hall, "Sexual Politics and Cultural Identity in The Masque of Blackness," in The Performance of Power: Theatrical Discourse and Politics, ed. Sue-Ellen Case and Janelle Reinelt (Iowa City: University of Iowa Press, 1991), 12.

${ }^{62}$ Orgel, “Jonson and the Amazons,” 134.

\section{NOTES TO CHAPTER 3} 1923), 412.

${ }^{1}$ E. K. Chambers, The Elizabethan Stage, Vol. 2, (Oxford: Clarendon Press,

${ }^{2}$ A list of the payments made can be found in Henslowe's diary, R. A. Foakes, ed. Henslowe's Diary, $2^{\text {nd }}$ ed. (New York: Cambridge University Press, 2002), 213-25. Payments are also listed for playbooks and properties.

${ }^{3}$ Chambers, Vol. 2, 256.

${ }^{4}$ James H. Forse, Art Imitates Business: Commercial and Political Influences in Elizabethan Theatre. (Bowling Green: Bowling Green State University Press, 1993), 15. For a fuller discussion of the financial significance of costumes to a professional company's survival, see Jones and Stallybrass, Renaissance Clothing and the Materials of Memory (New York: Cambridge University Press, 2000), 178-9.

${ }^{5}$ John Chamberlain, The Chamberlain Letters, ed. Elizabeth McClure Thomson (New York: G. P. Putnam's Sons, 1965), 288.

${ }^{6}$ Jean MacIntyre and Garrett P. J. Epp, “'Cloathes worth all the rest': Costumes and Properties," in A New History of EarlyEnglish Drama, ed. John D. Cox and David Scott Kastan (New York: Columbia University Press, 1997), 284.

${ }^{7}$ Leslie Hotson, The Commonwealth and Restoration Stage (Cambridge: Harvard University Press, 1928), 40-1.

${ }^{8}$ James Wright, Historia histrionica; an historical account of the Englishstage by James Wright [and] Roscius Anglicanus; or an historical review of the stage by John Downes, Preface by Arthur Freeman (New York: Garland, 1974), 9.

${ }^{9}$ Scott McMillin and Sally-Beth MacLean, The Queen's Men and their Plays (New York: Cambridge University Press, 1998), 128. 
${ }^{10}$ Here I am using the modernized spellings provided in McMillin and MacLean, 125. My text of the play, which I cite below, is Robert Wilson, An Edition of Robert Wilson's The Three Ladies of London and The Three Lords and Three Ladies of London, ed. H. S. D. Mithal (New York: Garland, 1988).

${ }^{11}$ H. S. D. Mithal, ed., An Edition of Robert Wilson's The Three Ladies of London and The Three Lords and Three Ladies of London (New York: Garland, 1988), 150.

${ }^{12}$ McMillin and Maclean, 125.

${ }^{13}$ Barbara A. Mowat, “'The Getting Up of the Spectacle': The Role of the Visual on the Elizabethan Stage, 1576-1600," in The Elizabethan Theatre IX, ed. G. R. Hubbard (Ontario: P. D. Meany, 1981), 62-3.

${ }^{14}$ Ibid., 63.

${ }^{15}$ Ibid.

${ }^{16}$ Ibid., 64.

${ }^{17}$ Ibid.

${ }^{18}$ Glynne Wickham, Early English Stages 1300-1660, Vol. 2 Part 1. (New York: Columbia University Press, 1963), 227.

${ }^{19}$ Wilson, 48

${ }^{20}$ The ensuing discussion of costumes in Tudor interludes is indebted to the third chapter in T. W. Craik, The Tudor Interlude: Stage, Costume, and Acting (Leicester: Leicester University Press, 1962).

${ }^{21}$ John D. Cox, The Devil and the Sacred in English Drama, 1350-1642 (New York: Cambridge University Press, 2000), 5.

${ }^{22}$ Thomas More, The Works of Sir Thomas More (London, 1557), 414.

${ }^{23}$ Qtd. in Craik, 52.

${ }^{24}$ My Shakespeare references are to The Riverside Shakespeare, $2^{\text {nd }}$ ed. ed. G. Blakemore Evans with the assistance of J. J. M. Tobin (Boston and New York: Houghton Mifflin, 1997).

${ }^{25}$ Craik, 71. 
${ }^{26}$ My references are to: Christopher Marlowe, Tamburlaine The Revels

Edition, ed. J. S. Cunningham (New York: Manchester University Press, 1981).

${ }^{27}$ Paul L. Hughes and James F. Larkin, Tudor Royal Proclamations Vol. 3 (New Haven: Yale University Press, 1969), 5.

${ }^{28}$ For some examples, see Phillis Cunnington and Catherine Lucas, Occupational Costume in England from the Eleventh Century to 1914 (New York: Barnes and Noble, 1967), 23, 26, 30.

${ }^{29}$ Alan S. Downer, “The Life of Our Design,” Hudson Review 2 (1949): 251.

${ }^{30}$ M. Channing Linthicum, Costume in the Drama of Shakespeare and his Contemporaries (Clarendon: Oxford, 1936), 125-7.

${ }^{31}$ Drawn from Foakes, Henslowe’s Diary, 291-4.

${ }^{32}$ Neil Carson, A Companion to Henslowe's Diary (New York: Cambridge University Press, 1988), 52.

33 Jones and Stallybrass , 184.

${ }^{34}$ Andrew Gurr, The Shakespearian Playing Companies (Oxford: Clarendon, 1996), 102-3.

${ }^{35}$ E. K. Chambers finds evidence for this practice in Henslowe's lending of money to his actors to purchase articles of apparel and to have them properly maintained. In companies that were not so autocratically run as Henslowe's, I suspect this practice was even more common, The Elizabethan Stage, Vol. 2 (Oxford: Clarendon Press, 1923), 185.

${ }^{36}$ Jean MacIntyre, Costumes and Scripts in the Elizabethan Theaters (Edmonton, Alberta: University of Alberta Press, 1992), 319.

${ }^{37}$ Albert Feuillerat, ed. Documents Relating to the Office of the Revels in the Time of Queen Elizabeth (Louvain: A. Uystpruyst, 1908), 365.

38 John Astington, English Court Theatre 1558-1642 (New York: Cambridge University Press, 1999), 12.

${ }^{39}$ Roslyn Lander Knutson, Playing Companies and Commerce in Shakespeare's Time (New York: Cambridge University Press, 2001), 73.

${ }^{40}$ G. K. Hunter, "Flatcaps and Bluecoats: Visual Signals on the Elizabethan Stage” Essays and Studies 33 (1980): 33-4. 
${ }^{41}$ Cleanth Brooks, The Well Wrought Urn: Studies in the Structure of Poetry (New York: Harcourt, Brace, 1947), 34.

${ }^{42}$ All references are to the New Mermaids edition, Thomas Dekker, The Shoemaker's Holiday, ed. Anthony Parr (New York: W W Norton, 1990).

${ }^{43}$ Qtd. from Stephen Orgel, Impersonations: The Performance of Gender in Shakespeare's England (New York: Cambridge University Press, 1996), 83.

${ }^{44}$ This issue has been taken up at some length in the past. Perhaps the best consideration of the subject can be found in chapters 2 and 3 of Orgel's Impersonations.

${ }^{45}$ See chapter 2, "Fiction and Friction" in Stephen Greenblatt, Shakespearean Negotiations (Berkeley: University of California Press, 1988).

${ }^{46}$ Northrop Frye, The Anatomy of Criticism (Princeton: Princeton University Press, 1957), 167.

${ }^{47}$ It is probable that when the children's troupe first played Epicoene, they were not yet accorded this title. See the introduction to Ben Jonson, Epicoene, or The Silent Woman, ed. R. V. Holdsworth (New York: W W Norton, 1990, xvii.

${ }^{48}$ Ben Jonson, Epicoene, or The Silent Woman, ed. R. V. Holdsworth (New York: W W Norton, 1990).

${ }^{49}$ Karen Newman, "City Talk: Women and Commodification in Jonson's Epicoene,” ELH 56 (1989): 507.

\section{NOTES TO CHAPTER 4}

${ }^{1}$ R. C. Bald, "Preface” in A Game at Chesse by Thomas Middleton, ed. R. C. Bald (Cambridge: Cambridge University Press, 1928), ix.

${ }^{2}$ Ann Rosalind Jones and Peter Stallybrass, Renaissance Clothing and the Materials of Memory (New York: Cambridge University Press, 200), 181.

${ }^{3}$ T. H. Howard-Hill offers the fullest explanation of the different texts of $A$ Game at Chess in the second half of his book, Middleton's "Vulgar Pasquin": Essays on A Game at Chess (Newark: University of Delaware Press, 1995). For a summary of the issues, see the introduction to his edition of the play, in Middleton, A Game at Chess, ed. T. H. Howard-Hill, Revels Edition (New York: Manchester University Press, 1993), 2-10. 
${ }^{4}$ Print drawn from R. A. Foakes, Illustrations of the English Stage, 1580-1642 (London: Scolar Press, 1985).

${ }^{5}$ John R. Moore, “The Contemporary Significance of Middleton’s Game at Chesse,” PMLA 50 (1935), 763.

${ }^{6}$ T. H. Howard-Hill reproduces the pictures in his introduction to the play, 15, 25.

${ }^{7}$ A. R. Braunmuller, “'To the Globe I rowed': John Holles Sees A Game at Chess,” English Literary Renaissance 20:2 (1991): 341.

${ }^{8}$ Middleton, A Game at Chess, Appendix 1, Item 7, 198.

${ }^{9}$ T. H. Howard-Hill, "Introduction," in A Game at Chess by Thomas Middleton, Revels Edition (New York: Manchester University Press, 1993), 16.

${ }^{10}$ I do not mean to suggest that all English audience members perceived the events in the same way. However, it must be acknowledged that these events were known by all who attended the production and influenced how it was experienced. For a consideration of the complex relationship between politics and A Game at Chess, see Thomas Postlewait, "From Event to Context to Event: A Problem in the Writing of Theatre History," in Critical Theory and Performance, Eds. Janelle Reinelt and Joseph Roach (Ann Arbor: University of Michigan Press, 2003).

${ }^{11}$ Middleton, A Game at Chess, Appendix 1, Item 7, 198-9.

${ }^{12}$ Middleton, A Game at Chess, Appendix 1, Item 5, $194-5$.

${ }^{13}$ Middleton, A Game at Chess, Appendix 1, Item 8, 200.

${ }^{14}$ Middleton, A Game at Chess, Appendix 1, Item 20, 204.

${ }^{15}$ Middleton, A Game at Chess, Appendix 1, Item 7, 198.

${ }^{16}$ Middleton, A Game at Chess, Appendix 1, Item 5, 195.

${ }^{17}$ Howard-Hill, “Introduction,” 29.

${ }^{18}$ Print drawn from R. A. Foakes, Illustrations of the English Stage, 15801642 (London: Scolar Press, 1985).

${ }^{19}$ Howard-Hill, “Introduction,” 29. Among his “villainies,” Gondomar instigated the proceedings that led to the execution of Raleigh in 1619 and was a major supporter of the marriage match between Charles and the Spanish Infanta. 
20 Thomas Middleton, A Game at Chess, Revels edition, ed. T. H. HowardHill (Manchester: Manchester University Press, 1993). All quotes are from this edition.

${ }^{21}$ Moore, 762.

${ }^{22}$ Willett Cunnington and Phillis Cunnington, Handbook of English Costume in the Seventeenth Century (London: Faber and Faber), 99.

${ }^{23}$ Seven if, as Howard-Hill has suggested, Error is dressed as a Jesuit. He notes that Holles apparently missed his vocative "Error" and calls the character his "disciple” in T. H. Howard Hill, “The Unique Eye-Witness Report of Middleton's A Game at Chess,” Review of English Studies 42:166 (1991): 172.

${ }^{24}$ Christopher Haigh, English Reformations: Religion, Politics, and Society under the Tutors (Oxford: Clarendon Press, 1993), 286.

${ }^{25}$ Haigh, 287.

${ }^{26}$ Roger Lockyer, Tudor and Stuart Britain: 1471-1714 (London: Longmans, 1964), 231.

${ }^{27}$ In 1618, Frederick misguidedly accepted the throne in Bohemia when it was offered to him by the Protestant Bohemian nobles University Presson the death of the Emperor Mathias. This went counter to the long custom whereby the catholic Habsburg emperors were also the kings of Bohemia. The two results were (1) that Frederick became a hero in England for championing the Protestant cause on the continent and (2) open war ensued which ravaged Europe and left Frederick and Elizabeth exiled in the Netherlands. Lockyer, 236.

${ }^{28}$ Robin Clifton, "Fear of Popery,” in The Origins of the English Civil War, ed. Conrad Russel (New York: Macmillan, 1973), 147.

${ }^{29}$ The Black Knight's Pawn notes that “This' a strange habit for a holy father, A president of poverty especially” (4.1.6-7).

${ }^{30}$ Swapan Chakravorty, Society and Politics in the plays of Thomas Middleton (Oxford: Clarendon Press, 1996), 178.

${ }^{31}$ Jean MacIntyre and Garrett P. J. Epp, 275. T. W. Craik notes that "the pretence of vices to be virtues is a theme almost universal in the interludes, and in allegorical literature in general,” The Tudor Interlude: Stage, Costume, Acting (Leicester: Leicester University Press, 1962), 87. 
${ }^{32}$ Middleton, A Game at Chess, Appendix 1, Item 7, 199.

${ }^{33}$ Postlewait.

${ }^{34}$ Braunmuller, 353. Jane Sherman suggests that “the White King's Pawn is not so much Cranfield as a composite of Northampton, Carr, Suffolk, Secretary Lake, and Secretary Calvert” in “The Pawns' Allegory in Middleton's A Game at Chesse, Review of English STudies, N. S., 29 (1978), 156.

${ }^{35}$ In A Critical Study of the work of William Rowley, Gillian A. Sanderman argues that William Rowley, who had the reputation of playing fat clown parts, performed the role of the Fat Bishop, Ph.D. diss. University of London, 1974.

${ }^{36}$ Print drawn from R. A. Foakes, Illustrations of the English Stage, 15801642 (London: Scolar Press, 1985).

${ }^{37}$ Will Fisher, “The Renaissance Beard: Masculinity in Early Modern England,” Renaissance Quarterly 54 (2001): 156.

${ }^{38}$ William Shakespeare, As You Like It in The Riverside Shakespeare, $2^{\text {nd }}$ ed. ed. G. Blakemore Evans (New York: Houghton Mifflin, 1997). All Shakespeare quotes are from this edition.

39 The paintings from which these pictures are drawn appear in Brian Reade, “The Dominance of Spain,” in Fashions of the Renaissance (New York: Harper \& Brothers, 1951), 241, 256. The first was completed around 1625. The second was completed 1632-4.

${ }^{40}$ Moore, 761-2.

${ }^{41}$ Thomas Middleton and Thomas Dekker, The Roaring Girl, Revels Edition, ed. Paul Mulholland (Manchester: Manchester University Press, 1987), Epistle.1-10.

\section{NOTES TO CHAPTER 5}

${ }^{1}$ Sergei Labanov-Rostovsky, “The Triumphes of Golde: Economic Authority in the Jacobean Lord Mayor’s Show,” ELH 60 (1993): 880.

2 David M. Bergeron, “The Elizabethan Lord Mayor’s Show,” SEL: Studies in English Literature, 1500-1900 10 (1970): 269.

${ }^{3}$ James Knowles, "The Spectacle of the Realm: Civic Consciousness, rhetoric and tirual in early modern London," in Theatre and Government Under the Early 
Stuarts, ed. J. R. Mulryne and Margaret Shewring (New York: Cambridge University Press, 1993), 158.

${ }^{4}$ Lupold Von Wedel, “Journey Through England and Scottland made by Lupold Von Wedel in the Years 1584 and 1585," Transactions of the Royal Historical Society, n.s. 9 (1895): 255.

${ }^{5}$ Allen B. Hinds, ed., Calendar of State Papers, Venetian, vol. 15 (London: HMSO, 1909), 61.

${ }^{6}$ Gordon Kipling, “Triumphal Drama: Form in English Civic Pageantry,” Renaissance Drama n.s. 8 (1977): 42.

${ }^{7}$ Because the speeches would likely have been heard only by the Lord Mayor and those standing close to him, Theodore B. Leinwand believes that it is important to move beyond the rather formal discussions that tend to dominate most studies of the shows. His answer is to direct his attention to the lives and mores of the merchants involved to see how the shows directly spoke to their ideal audience, "London Triumphing: The Jacobean Lord Mayor’s Show” CLIO 11:2 (1982): 139.

${ }^{8}$ Robert Withington, English Pageantry: An Historical Outline (Cambridge: Harvard University Press, 1918), 200.

${ }^{9}$ D. J. Gordon and Jean Robertson, eds., Malone Society Collections III (Oxford: The Malone Society, 1954), xlii.

${ }^{10}$ London's population was many times that of the next largest city in England, reaching 160-180,000 by 1600 and continuing to increase in the seventeenth century. With the streets of the city filled to capacity, it strikes me as possible that more people came to see a single Lord Mayor's procession than attended all of the early modern productions of Hamlet.

${ }^{11}$ Labanov-Rostovsky, 880.

12 Knowles, 159.

${ }^{13}$ In The Elizabethan Stage, E. K. Chambers simply states in a footnote that "He [Von Wedel] gives full details of all the installation ceremonies," vol. 1 (Oxford: Clarendon Press, 1923), 136. David M. Bergeron mentions only that Von Wedel "describes in detail the ceremonies when the new mayor took the oath of office" in English Civic Pageantry 1558-1642 (Columbia, South Carolina: University of South Carolina Press, 1971), 130. 
${ }^{14}$ Lupold Von Wedel, “Journey Through England and Scottland Made by Lupold Von Wedel in the Years 1584 and 1585,” Transactions of the Royal Historical Society, n.s. 9 (1895): 252-3.

15 This is not to suggest that the ceremony was performed in exactly the same way year after year, but that it is understood by those involved to be unchangeable.

${ }^{16}$ For a discussion of speech acts within a larger discussion of performative writing, see Della Pollock, "Performative Writing," in The Ends of Performance, ed. Peggy Phelan and Jill Lane (New York: New York University Press, 1998), 73-103.

${ }^{17}$ M. C. Bradbrook notes that the Roman reward for a conqueror, his Triumph, became the term of the London livery companies for the procession that marked the installation of the Lord Mayor, "The Politics of Pageantry: Social Implications in Jacobean London,” in Poetry and Drama 1500-1700, Essays in Honour of Harold F. Brooks, ed. Antony Coleman and Antony Hammond (New York: Methuen, 1981), 60.

18 John H. Astington, “The Ages of Man and the Lord Mayor's Show," in Other Voices, Other Views: Expanding the Canon in English Renaissance Studies, ed. Helen Ostovich, Mary V. Silcox, and Graham Roebuck (Newark: University of Delaware Press, 1999), 80.

${ }^{19}$ Von Wedel, 254.

${ }^{20}$ Every other year at Easter, the members of the King's Men would receive livery of three yards of bastard scarlet for a cloak and a quarter yard of crimson velvet for a cape.

${ }^{21}$ Qtd. in Knowles, 165.

${ }^{22}$ Sir Thomas White.

${ }^{23}$ John Gough Nichols, ed., The Diary of Henry Machyn, Citizen and Merchant-Taylor of London, From A.D. 1550 to A.D. 1563 (New York: AMS, 1968), 47.

${ }^{24}$ Von Wedel, 253.

${ }^{25}$ James P. Lusardi and Henk Gras, “Abram Booth’s Eyewitness Account of the 1629 Lord Mayor’s Show,” Shakespeare Bulletin 11 (1993): 22.

${ }^{26}$ John C. Meagher, “The London Lord Mayor’s Show of 1590,” English Literary Renaissance 3 (1973): 94. 
${ }^{27}$ Von Wedel, 254.

${ }^{28}$ Knowles, 166.

${ }^{29}$ Qtd. in Ian Archer, “The Nostalgia of John Stow,” in The Theatrical City, ed. David L. Smith, Richard Strier, and David Bevington (New York: Cambridge University Press, 1995), 18.

${ }^{30}$ David M. Bergeron, ed., Pageants and Entertainments of Anthony Munday: A Critical Edition (New York: Garland, 1985), xiii.

${ }^{31}$ Knowles, 182.

32 Picture is drawn from the album of Michael van Meer and appears in Ian Archer, “The Nostalgia of John Stow," in The Theatrical City: Culture, Theatre and Politics in London, 1676-1649 (New York: Cambridge University Press, 1995), 28.

${ }^{33}$ William Smythe, a citizen and haberdasher of London identified the sword bearer's hat as a

"cappe [cap] of honor" in Nathan Drake, Shakespeare and His Times, Vol. 2

(London: 1817), 164. Von Wedel noted the hat as well, stating that "then came the man with the sword wearing a broad and high open cap of fur,” 254.

${ }^{34}$ Gordon and Robertson record that the Grocers paid the extraordinary sums for the food they tossed to the spectators: "£5. 7s. 8d. Payd for 50 sugar loaues, $36^{\text {li }}$ of nuttmegge $14^{\mathrm{li}}$ of dates and $114^{\mathrm{li}}$ of ginger," 93.

${ }^{35}$ Hinds, 61-2.

${ }^{36}$ Busino’s report is almost certainly incomplete. For instance, it is almost impossible to believe that the Lord Mayor's sword bearer was not in the procession. That stated, I want to open up the possibility that the liverymen and the bachelors did not, in fact, appear in the procession in 1617 but were all numbered among those that stood on the side of the roads taken by the Lord Mayor. Busino states that over a thousand gownsmen lined the streets: "over the left shoulder they wore a sort of satchel, one half of red cloth and the other black, fastened to a narrow stole. There were other gownsmen in long cloth gowns with satchels of red damask. These were younger men than th eothers, and their duty is to wait at table during the banquet. Others again wore another kind of appendage, also red, on the shoulder, and a fourth set had small stoles about the throat," 61.

37 The magnanimity of the Lord Mayor's guild in providing apparel for the poor men in the procession was not all spectacle. As Leinwand notes, the most elite members of the city, those from whom the Lord Mayor was typically chosen annually 
gave an enormous amount of charitable gifts. Charity was one of the ways that a liveryman could begin to distinguish himself if he wanted to become an alderman or eventually become mayor. Leinwand, 142.

${ }^{38}$ In 1613, the Grocers paid the exorbitant sum of $£ 168.12$ s. 5d. for "expenses connected with gowns, coats, sleeves, caps for the poor men” in Malone Society Collection, 86.

39 The verse reads: "But if my ffeasting [sic] haue to lauish bin / I must be fforced [sic] to turne Child a gin / In stead of posie beare a burning taper / thus man begins in beauty ends in uaper” Astington, 78.

${ }^{40}$ Ibid.

${ }^{41}$ Ibid, 79.

42 The verse that accompanies "Youth": "Next place of office which I doe attaine / is swashing whiffler with my staff and chaine / In which hot office when I long haue binn / I swaggering leue and to be stayd beginn.” Astington, 76.

43 The verse that accompanies "Manhood": "My liuery gowne and hoode I now haue gott / with which in ranck and ffile to poules I trott / And swim in sholes to westminster in barges / and to feed high spare nether cost nor charges.” Astington, 77.

${ }^{44}$ Ibid, 77.

45 Thomas Dekker, The Complete Works of Thomas Dekker, Vol. 4, ed. Fredson Bowers (New York: Cambridge University Press, 1968), 83.

${ }^{46}$ See chapter 1.

${ }^{47}$ Drake, 164.

${ }^{48}$ Leinwand, 148.

${ }^{49}$ They are not working drawings, but a set executed for submission to the Company for their approval, Gordon and Robertson, xliii-xliv.

50 "Fishermen, in this fishing Busse are seriously at labour, drawing up their Nets, laden with living fish, and bestowing them bountifully among the people” in Bergeron, Pageants and Entertainments of Anthony Munday, 105.

${ }^{51}$ Drawn from Bergeron, English Civic Pageantry, 150-1.

52 Drawn from Bergeron, English Civic Pageantry, 150-1. 
${ }^{53}$ I would recommend that one first look at Bergeron's, English Civic Pageantry which devotes separate chapters to the shows written by Anthony Munday, Thomas Dekker, Thomas Middleton, and Thomas Heywood. Bergeron also has a chapter devoted to John Squire, John Webster, and John Taylor. He considers the pageant wagons primarily as appropriate stages for the speeches.

${ }^{54}$ Glynne Wickham, Early English Stages, 1300 to 1600, Vol. 2, part 1 (New York: Columbia University Press, 1963), 239.

\section{NOTES TO CONCLUSION}

${ }^{1}$ Stephen Greenblatt, Shakespearean Negotiations (Berkeley and Los Angeles: University of California Press, 1988), 1.

${ }^{2}$ Stephen Greenblatt, Renaissance Self-Fashioning (Chicago: University of Chicago Press, 1980).

${ }^{3}$ Stephen Orgel, Impersonations: The Performance of Gender in Shakespeare's England (New York: Cambridge University Press, 1996), 104.

${ }^{4}$ Arthur F. Kinney, Shakespeare by Stages: An Historical Introduction (Malden, MA: Blackwell, 1993).

${ }^{5}$ Fernand Braudel, Capitalism and Material Life, 1400-1800, Translated by Miriam Kochan (London: Fontana/Collins, 1974), 135. 


\section{APPENDIX A}

The following inventory of costumes and properties for the Lord Admiral's Men was most likely written by Philip Henslowe in March, 1598. It is drawn from R. A. Foakes, ed., Henslowe's Diary, $2^{\text {nd }}$ ed. (New York: Cambridge University Press, 2002), 317-23.

The booke of Inventary of the goods of my Lord Admeralles men, tacken the 10 of Marche in the yeare 1598.

Gone and loste.

Item, i orenge taney satten dublet, layd thycke with gowld lace. Item, i blew tafetie sewt.

Item, i payr of carnatyon satten Vanesyons, layd with gold lace. Item, i longe-shanckes sewte.

Item, Sponnes dublet pyncket.

Item, iSpanerd gyrcken.

Item, Harey the fyftes dublet.

Item, Harey the fyftes vallet gowne.

Item, i fryers gowne.

Item, i lyttel dublet for boye.

The Enventary of the Clownes Sewtes and Hermetes Sewtes, with dievers other sewtes, as followeth, 1598, the 10 of March.

Item, i senetores gowne, i hoode, and 5 senetores capes.

Item, i sewtte for Nepton; Fierdrackes sewtes for Dobe.

Item, iiii genesareyes gownes, and iiii thorchberers sewtes.

Item, iii payer of red strasers, and iii fares gowne of buckrome.

Item, iiii Herwodes cottes, and iii sogers cottes, and i green gown for Maryan.

Item, vi grene cottes for Roben Hoode, and iiii knaves sewtes. 
Item, ii payer of grene hosse, and Andersones sewte. I whitt shepen clocke.

Item, ii rosset cottes, and i black frese cotte, and iiii prestes cottes.

Item, ii whitt sheperdes cottes, and ii Danes sewtes, and i payer of Danes hosse.

Item, The Mores lymes, and Hercolles lymes, and Will. Sommers sewtte.

Item, ii Orlates sewtes, hates and gorgetts, and vii anteckes cootes.

Item, Cathemer sewte, i payer of cloth whitte stockens, iiii Turckes hedes.

Item, iiii freyers gownes and iiii hoodes to them, and i fooles coate, cape, and babell, and branhowlttes bodeys, and merlen gowne and cape.

Item, ii black saye gownes, and ii cotton gownes, and i rede saye gowne.

Item, i mawe gowne of calleco for the quene, i carnowll hatte.

Item, i red sewt of cloth for pyge, layed with whitt lace.

Item, $\mathrm{v}$ payer of hosse for the clowne, and $\mathrm{v}$ gerkenes for them.

Item, iii payer of canvas hosse for asane, ii payer of black strocers.

Item, i yelow leather dublett for a clowne, i Whittcomes dublett poke.

Item, Eves bodeyes, i pedante trusser, and iii donnes hattes.

Item, i payer of yelow cotton sleves, i gostes sewt, and i gostes bodeyes.

Item, xviii copes and hattes, Verones sonnes hosse.

Item, iii trumpettes and a drum, and a trebel viall, a basse viall, a bandore, a sytteren, $\mathrm{i}$ anshente, i whitt hatte.

Item, i hatte for Robin Hoode, i hobihorse.

Item, $\mathrm{v}$ shertes, and i serpelowes, iiii ferdingalles.

Item, vi head-tiers, i fane, iiii rebatos, ii gyrketruses.

Item, i longe sorde.

The Enventary of all the apparell for my Lord Admiralles men, tacken the 10 of marche 1598.-Leaft above in the tier-house in the cheast.

Item, My Lord Caffes gercken, \& his hoosse.

Item, i payer of hosse for the Dowlfen.

Item, i murey lether gyrcken, \& i white lether gercken.

Item, i black lether gearken, \& Nabesathe sewte.

Item, i payer of hosse, \& a gercken for Valteger

Item, ii leather anteckes cottes with basses, for Fayeton.

Item, payer of bodeyes for Alles Pearce.

The Enventary tacken of all the properties for my Lord Admeralles men, the 10 of Marche 1598.

Item, i rocke, i cage, i tombe, i Hell mought.

Item, i tome of Guido, i tome of Dido, i bedsteade.

Item, viii lances, i payer of stayers for Fayeton.

Item, ii stepells, \& j chyme of belles, \& i beacon.

Item, i hecfor for the playe of Faeton, the limes dead.

Item, i globe, \& i golden scepter; iii clobes. 
Item, ii marchepanes, \& the sittie of Rome.

Item, i gowlden flece; ii rackets; i baye tree.

Item, i wooden hatchett; i lether hatchete.

Item, i wooden canepie; owld Mahemetes head.

Item, i lyone skin; i beares skyne; \& Faetones lymes, \& Faeton charete; \& Argosse heade.

Item, Nepun forcke \& garland.

Item, i crosers stafe; Kentes woden leage.

Item, Ierosses head, \& raynbowe; i littell alter.

Item, viii viserdes; Tamberlyne brydell; i wooden matook.

Item, Cupedes bowe, \& quiver; the clothe of the Sone \& Mone.

Item, i bores heade \& Serberosse iii heades.

Item, i Cadeseus; ii mose banckes, \& i snake.

Item, ii fanes of feathers; Belendon stable; j tree of gowlden apelles; Tantelouse tre; ix eyorn targates.

Item, i copper targate, \& xvii foyles.

Item, iiii wooden targates; i greve armer.

Item, i syne for Mother Readcap; i buckler.

Item, Mercures wings; Tasso picter; i helmet with a dragon; i shelde, with iii lyones; i eleme bowle.

Item, i chayne of dragons; i gylte speare.

Item, ii coffenes; i bulles head; and i vylter.

Item, iii tymbrells, i dragon in fostes.

Item, i lyone; ii lyon heades; i great horse with his leages; i sack-bute.

Item, i whell and frame in the Sege of London.

Item, i paire of rowghte gloves.

Item, poopes miter.

Item, iii Imperial crownes; i playne crowne.

Item, i gostes crown; i crown with a sone.

Item, frame for the heading in Black JOne.

Item, i black dogge.

Item, i cauderm for the Jewe.

The Enventorey of all the aparell of the Lord Admeralles men, taken the $13^{\text {th }}$ of Marche 1598, as followeth:

Item, i payer of whitte saten Venesons cut with copper lace.

Item, i ash coller satten doublett, layed with gold lace.

Item, i peche coller satten doublett.

Item, i owld white satten dublette.

Item, i bleu tafitie sewtte.

Item, i Mores cotte.

Item, Pyges damask gowne.

Item, i black satten cotte. 
Item, i harcoller tafitie sewte of pygges.

Item, i white tafitie sewte of pygges.

Item, Vartemar sewtte.

Item, i great pechcoller dublet, with sylver lace.

Item, i white satten dublet pynckte.

Item, i owld white satten dublet pnckte.

Item, payer of satten Venesyan satten ymbradered.

Item, i payer of French hosse, cloth of gowld.

Item, i payer of cloth of gowld hosse with sylver paines.

Item, i payer of cloth of sylver hosse with satten and sylver panes.

Item, Tamberlynes cotte with coper lace.

Item, i read clock with white coper lace.

Item, i read clocke, with read coper lace.

Item, i shorte clocke of taney satten with sleves.

Item, i shorte clocke of black satten with sleves.

Item, Labesyas clocke, with gowld buttenes.

Item, i payer of read cloth hosse of Venesyans, with sylver lace of coper.

Item, Valteger robe of rich tafitie.

Item, Junoes cotte.

Item, i hode for the wech.

Item, i read stamel clocke with whitte coper lace.

Item, i read stamel clocke with read coper lace.

Item, i cloth clocke of russete with coper lace, called Guydoes clocke.

Item, i short clocke of black velvet, with sleves faced with shagg.

Item, i short clocke of black vellet, faced with white fore.

Item, i manes gown, faced with whitte fore.

Item, Dobes cotte of cloth of sylver.

Item, i payer of pechecoler Venesyones uncut, with read coper lace.

Item, i read scarllet clocke with sylver buttones.

Item, i longe black velvet clock, layd with brod lace black.

Item, i black satten sewtte.

Item, i blacke velvet clocke, layd with twyst lace blacke.

Item, Perowes sewt, which $\mathrm{W}^{\mathrm{m}}$ Sley were.

Item, i payer of pechcoler hosse with sylver corlled panes.

Item, i payer of black cloth of sylver hosse, drawne owt with tufed tafittie.

Item, Tamberlanes breches of crymson vellvet.

Item, i payer of sylk howse with panes of sylver corlled lace.

Item, i Faeytone sewte.

Item, Roben Hoodes sewtte.

Item, i payer of cloth of gowld hose with gowld corlle panes.

Item, i payer of rowne hosse buffe with gowld lace.

Item, i payer of mows coller Venesyans with R. brode gowld lace.

Item, i flame collerde dublet pynked.

Item, i blacke satten dublet, layd thyck wyth blacke and gowld lace. 
Item, i carnacyon dubled cutt, layd with gowld lace.

Item, i white satten dublet, faced with read tafetie.

Item, i grene gyrcken with sylver lace.

Item, i black gyrcken with sylver lace.

Item, i read gyrcken with sylver lace.

Item, i read Spanes dublett styched.

Item, i peche coller satten casse.

Item, Tasoes robe.

Item, murey robe with sleves.

Item, i blewe robe with sleves.

Item, i oren taney robe with sleves.

Item, i pech collerd hallf robe.

Item, i lane robe with spangells.

Item, i white \& orenge taney skarf spangled.

Item, Dides robe.

Item, iii payer of basses.

Item, i white tafitie sherte with gowld frenge.

Item, the fryers trusse in Roben Hoode.

Item, i littell gacket for Pygge.

Item, i womanes gown of cloth of gowld.

Item, i orenge taney vellet gowe with sylver lace, for women.

Item, i black velvet gowne ymbradered with sylk \& gowld lace, for women.

Item, i greve armer.

Item, Harye the v. velvet gowne.

Item, i payer of crymson satten Venysiones, layd with gowld lace.

Item, i blew tafitie sewte, layd with sylver lace.

Item, i Longeshankes seute.

Item, i orange coller satten dublett, layd with gowld lace.

Item, Harye the v. satten dublet, layd with gowld lace.

Item, i Spanes casse dublet of crymson pyncked.

Item, i Spanes gearcken layd with sylver lace.

Item, i wattshode tafitie dublet for a boye.

Item, ii payer of basses, i whitte, i blewe, of sasnett.

Item, i freyers gowne of graye. 


\section{APPENDIX B}

The following inventory of costumes and properties for the Lord Admiral's Men was written in Edward Alleyn's hand, likely between 1598 and 1602. It is drawn from R. A. Foakes, ed., Henslowe's Diary, $2^{\text {nd }}$ ed. (New York: Cambridge University Press, 2002), 291-4.

1 A scarlett cloke $w^{\text {th }}$ ii brode gould Laces: $\mathrm{w}^{\mathrm{t}}$ gould buttens of the sam downe the sids

2 A black velvett cloke

A scarlett cloke Layde [the] downe $\mathrm{w}^{\mathrm{t}}$ silver Lace and silver buttens

4 A short velvett cap clok embroydered $\mathrm{w}^{\mathrm{t}}$ gould and gould spangles

5 A watshod sattins clok $\mathrm{w}^{\mathrm{t}} \mathrm{v}$ gould laces

6 A pur[l]pell sattin $\mathrm{w}^{\mathrm{t} e l t e d} \mathrm{w}^{\mathrm{t}}$ velvett and silver twist

7 A black tufted cloke

8 A damask cloke garded cloke garded $\mathrm{w}^{\mathrm{t}}$ velvett

A longe blak tafata cloke

A colored bugell for aboye

A scarlett $\mathrm{w}^{\mathrm{t}}$ buttens of gould fact $\mathrm{w}^{\mathrm{t}}$ blew velvett

12 A scarlett fact $\mathrm{w}^{\mathrm{t}}$ blak velvett

13 A stamell cloke $\mathrm{w}^{\mathrm{t}}$ [b]gould lace

14 blak bugell cloke

\section{Gownes}

1 hary $\mathrm{y}^{\mathrm{e}}$ viii gowne

2 the blak velvett gowne $\mathrm{w}^{\mathrm{t}}$ wight fure

3 A crimosin Robe strypt $\mathrm{w}^{\mathrm{t}}$ gould fact $\mathrm{w}^{\mathrm{t}}$ ermin

4 on of wrought cloth of gould

5 on of red silk w ${ }^{t}$ gould buttens

6 a cardinalls gowne

7 wemens gowns

8 i blak velvett embroyde

$9 \mathrm{w}^{\mathrm{t}}$ gould

10 i cloth of gould candish his stuf 
11 i blak velvett lact and drawne owt $\mathrm{w}^{\mathrm{t}}$ wight sarsnett

12 A black silk w ${ }^{\mathrm{t}}$ red flush

13 A cloth of silver for pan

14 a yelow silk gowne

15 a red silk gowne

16 angels silk

17 ii blew calico gowns

Antik sutes

1 a cote of crimosen velvett cutt in payns and embryderd in gould

2 i cloth of gould cote $\mathrm{w}^{\mathrm{t}}$ grene bases

3 i cloth of gould coted $\mathrm{w}^{\mathrm{t}}$ oraingtawny bases

4 i cloth of silver cott $\mathrm{w}^{\mathrm{t}}$ blewe silk \& tinsell bases

5 i blew damask cote the more

6 a red velvett hors mans cote

7 A yelow tafata pd

8 cloth of gould horsmans cote

9 cloth of bodkin homans cote

10 orayngtany horsmans cot of cloth lact

11 daniels gowne

12 blew embroyderde bases

13 will somers cote

14 wight embroyd bases

15 gilt lether cot

16 ii hedtirs sett $\mathrm{w}^{\mathrm{t}}$ stons

Jerkings and dublets

1 A crymosin velvett pd $w^{t}$ gould buttens \& Lace

2 a crymasin sattin case lact $\mathrm{w}^{\mathrm{t}}$ gould lace all over

3 A velvett dublett cut diamond lact $\mathrm{w}^{\mathrm{t}}$ gould lace and spang

4 a dublett of blak velvett cut on sillver tinsell

5 A ginger colored dublett

6 i wight sattin cute onwight

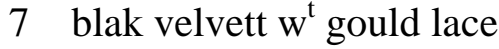

8 green velvett

9 blak tafata cut on blak velvett lacte $\mathrm{w}^{\mathrm{t}}$ bugell

10 blak velvett playne

11 ould wight sattin

12 red velvett for a boye

13 A carnation velvett lact $\mathrm{w}^{\mathrm{t}}$ silver

14 A yelow spangled case

15 red velvett $\mathrm{w}^{\mathrm{t}}$ blew sattin sleves \& case

16 cloth of silver Jerkin

17 faustus Jerkin his clok 
frenchose

1 blew velvett embr $\mathrm{w}^{\mathrm{t}}$ gould paynes blew sattin scalin

2 silver paynes lact $\mathrm{w}^{\mathrm{t}}$ carnation satins lact over $\mathrm{w}^{\mathrm{t}}$ silver

3 the guises

4 Rich payns $\mathrm{w}^{\mathrm{t}}$ Long stokins

5 gould payns $\mathrm{w}^{\mathrm{t}}$ blak stript scalings of canis

6 gould payns $\mathrm{w}^{\mathrm{t}}$ velvett scalings

7 gould payns $\mathrm{w}^{\mathrm{t}}$ red strypt scalings

8 black bugell

9 red payns for a boy $\mathrm{w}^{\mathrm{t}}$ yelo scalins

10 pryams hoes

11 spangled hoes

venetians

1 A purple velvett cut in dimonds Lact \& spangels

2 red velved lact $\mathrm{w}^{\mathrm{t}}$ gould spanish

3 a purpell velvet emproydored $\mathrm{w}^{\mathrm{t}}$ silver cut on tinsel

4 green velvett lact $\mathrm{w}^{\mathrm{t}}$ gould spanish

5 blake velvett

6 cloth of silver

7 gren strypt sattin

8 cloth of gould for a boye 


\section{BIBLIOGRAPHY}

“An Homily against Excess of Apparel.” 1563. Certain Sermons or Homilies. Oxford: Oxford University Press, 1844.

Agnew, Jean-Christophe. Worlds Apart: The Market and the Theatre in AngloAmerican Thought, 1550-1750. Cambridge: Cambridge University Press, 1986.

Akrigg, G. P. V. Jacobean Pageant, or The Court of James I. London: Hamish Hamilton, 1962.

Amussen, S. An Ordered Society: Gender and Class in Early Modern England. Oxford: Blackwell, 1988.

Anglo, Sidney. "Archives of the English Tournament: Score Cheques and Lists.” Journal of the Society of Archivists 2 (1962): 153-62.

—. "The Evolution of the Early Tudor Disguising, Pageant, and Mask." Renaissance Drama, no.1 (1968): 3-44.

— . "The Hampton Court Painting of the Field of Cloth of Gold.” Antiquaries Journal 46 (1966): 287-307.

—. Images of Tudor Kingship. London: Seaby, 1992.

—. Spectacle, Pageantry, and Early Tudor Policy. 2d ed. Oxford: Oxford University Press, 1997.

Anon. The Taming of a Shrew. 1594. In Narrative and Dramatic Sources of Shakespeare, edited by Geoffrey Bullough. Vol. 1. London: Routledge and Kegan Paul, 1957.

Anton, Robert. “The Philosphers Third Satyr of Iupiter.” In The Philosophers Satyrs. London: 1616. 24-25.

Appadurai, Arjun. “Introduction: Commodities and the Politics of Value.” In The Social Life of Things: Commodities in Cultrual Perspective, edited by Arjun Appadurai. New York: Cambridge University Press, 1986. 3-63. 
Archer, Ian. The Pursuit of Stability: Social Relations in Elizabethan London.

Cambridge: Cambridge University Press, 1991.

. "Shakespeare’s London.” In A Companion to Shakespeare, edited by David Scott Kastan. Oxford: Blackwell, 2000. 43-56.

Arnold, Janet. A Handbook of Costume. London: Macmillan, 1973.

—_. “Jane Lambarde’s Mantle.” Costume 14 (1980): 56-72.

- Patterns of Fashion: The Cut and Construction of Clothes for Men and Women, c. 1560-1620. London: Macmillan, 1985.

- Queen Elizabeth's Wardrobe Unlock'd: The Inventories of the Wardrobe of Robes prepared in July 1600. Leeds: Maney, 1988.

Arnott, James Fullarton, and John William Robinson. English Theatrical Literature, 1559-1900: A Bibliography, Incorporating Robert W. Lowe's A

Bibliographical Account of English Theatrical Literature, Published in 1888. London: The Society for Theatre Research, 1970.

Ashelford, Jane. Dress in the Age of Elizabeth I. London: B. T. Batesford, 1988.

- A Visual History of Costume: The Sixteenth Century. New York: Drama Book Publishers, 1983.

Ashley, Kathleen, and Wim Huskens, eds. Moving Subjects: Processional Performance in the Middle Ages and the Renaissance. Atlanta: Rodopi, 2001.

Ashton, Geoffrey. Catalogue of the Paintings at the Theatre Museum. London: Victoria and Albert Museum, 1992.

Astington, John. “The Ages of Man and the Lord Mayor’s Show.” In Other Voices, Other Views: Expanding the Canon in English Renaissance Studies, edited by Helen Ostovich, Mary U. Silcox, and Graham Roebuck. Newark: University of Delaware Press, 1999. 74-90.

—. English Court Theatre. Cambridge: Cambridge University Press, 1999.

_ _ "Rereading Illustrations of the English Stage.” Shakespeare Survey: An Annual Survey of Shakespeare Studies and Production 50 (1997): 151-70.

_. "Tarlton and the Sanguine Temperament.” Theatre Notebook 53, no. 1 (1999): 2-7. 
_. "The 'Unrecorded Portrait' of Edward Alleyn.” Shakespeare Quarterly 44 (1993): 73-86.

Aston, Margaret. England's Iconoclasts: Laws Against Images. Oxford: Oxford University Press, 1988.

Auerbach, Erna. Tudor Artists. London: Athlone Press, 1954.

“AVISTA Sessions 1996: Cloth, Clothing, and Textiles.” AVISTA Forum 10 (199697): 5-14.

Axton, Marie. "The Tudor Mask and Elizabethan Court Drama.” In English Drama: Forms and Development: Essays in Honour of Muriel Clara Bradbrook, edited by Marie Axton and Raymond Williams. New York: Cambridge University Press, 1977. 24-47.

Bailey, Amanda. "Staging Sumptuousness: Regulating Identity in Early Modern England.” Ph.D. diss., University of Michigan, 1998.

Baldwin, Frances Elizabeth. Sumptuary Legislation and Personal Regulation in England. Baltimore: Johns Hopkins University Press, 1926.

Barker, Harley Granville. Prefaces to Shakespeare. Princeton, N.J.: Princeton University Press, 1974.

Barroll, Leeds. Anna of Denmark, Queen of England: A Cultural Biography. Philadelphia: University of Pennsylvania Press, 2001.

. "Theatre as Text: The Case of Queen Anna and the Jacobean Court Masque." in Elizabethan Theatre 14, edited by A.L. Magnusson and C.E. McGee. Toronto: P. D. Meany, 1996, 175-93.

Barry, Jonathan, ed. The Tudor and Stuart Town: A Reader in England Urban History, 1530-1688. Harlow, Essex: Longman, 1990.

Bath, Michael. Speaking Pictures: English Emblem Books and Renaissance Culture. Harlow, Essex: Longman, 1994.

Baumgarten, Linda. What Clothes Reveal: The Language of Clothes in Colonial and Federal America. New Haven, Conn.: Yale University Press, 2002.

Bawcutt, N. W., ed. The Control and Censorship of Caroline Drama: The Records of Sir Henry Herbert, Master of the Revels 1623-73. Oxford: Clarendon Press, 1996. 
Beckerman, Bernard. "Philip Henslowe.” In The Theatrical Manager in England and America, edited by Joseph W. Donohue, 19-62. Princeton, N.J.: Princeton University Press, 1971.

- Shakespeare at the Globe 1599-1609. New York: Macmillan, 1962.

Beier, A. L. "Social Problems in Elizabethan London.” Journal of International History 9 (1978): 203-21.

Beier, A. L., and Roger Finlay, eds. London, 1500-1700: The Making of the Metropolis. London: Longman, 1986.

Benhamou, Reed. “The Restraint of Excessive Apparel: England 1337-1604.” Dress 15 (1989): 250-60.

Bentley, G. E. The Jacobean and Caroline Stage. 7 vols. Oxford: Clarendon-Oxford University Press, 1941-68.

- The Profession of Dramatist in Shakespeare's Time, 1590-1642. Princeton, N.J.: Princeton University Press, 1971.

—. The Profession of Player in Shakespeare's Time, 1590-1642. Princeton, N.J.: Princeton University Press, 1984.

Bergeron, David. "Elizabeth’s Coronation Entry (1559): New Manuscript Evidence.” English Literary Renaissance 8 (1978): 3-8.

—_. "The Elizabethan Lord Mayor's Show.” SEL: Studies in English Literature 10 (1970): 269-85.

—. English Civic Pageantry, 1558-1642. London: Edward Arnold, 1971.

- Twentieth-Century Criticism of English Masques, Pageants, and Entertainments. With a supplement on the folk play and related forms by Harry B. Caldwell. San Antonio: Trinity University Press, 1972.

- Practicing Renaissance Scholarship. Pittsburgh, PA: Duquesne University Press, 2000.

- ed. Pageantry in the Shakespearean Theater. Athens: University of Georgia Press, 1985.

— ed. Pageants and Entertainments of Anthony Munday. New York: Garland, 1985. 
—

Berline, Michael. “Civic Ceremony in Early Modern England.” Urban Yearbook (1986): 15-27.

Besant, Walter. London in the Time of the Stuarts. London: A. \& C. Black, 1903.

Bevington, David. “'Blake and wyght, fowll and fayer': Stage Pictures in Wisdom.” In The Wisdom Symposium, edited by Milla Cozart Riggio. New York: AMS Press, 1986. 18-38.

- From Mankind to Marlowe: Growth of Structure in the Popular Drama of Tudor England. Cambridge, Mass.: Harvard University Press, 1962.

—. Tudor Drama and Politics. Cambridge, MA: Harvard University Press, 1968.

Bevington, David, and Peter Holbrook, eds. The Politics of the Stuart Court Masque. Cambridge: Cambridge University Press, 1998.

Blackstone, Mary A. "Patrons and Elizabethan Dramatic Companies.” The Elizabethan Theatre 10 (1988): 112-32.

Blakemore, Colin, and Sheila Jennet, eds. The Oxford Companion to the Body. Oxford: Oxford University Press, 2002.

Boas, Frederick S. University Drama in the Tudor Age. Oxford: Oxford University Press, 1914.

Boase, T. S. R. "Illustrations of Shakespeare's Plays in the Seventeenth and Eighteenth Centuries.” Journal of the Warburg Institute 10 (1947): 83-108.

Bonahue, Jr., Edward T. “Citizen History: Stow’s Survey of London.” SEL: Studies in English Literature 38 (1998): 61-85.

Bosanquet, E. F. English Printed Almanacs ... to the Year 1600. London: The Bibliographical society at the Chiswick press, 1917.

Boulton, Jeremy. Neighbourhood and Society: A London Suburb in the Seventeenth Century. Cambridge: Cambridge University Press, 1987.

Bowden, Peter. The Wool Trade in Tudor and Stuart England. London: Macmillan, 1962.

Bowers, Rick. John Lowin and Conclusions Upon Dances (1607). New York: 
Garland, 1988.

Boynton, Lindsay. The Elizabethan Militia, 1558-1638. London: Routledge and Kegan Paul, 1967.

Bradbrook, M. C. The Collected Papers of Muriel Bradbrook. 4 vols. Brighton: Harveter, 1982-89.

—. John Webster: Citizen and Dramatist. New York: Columbia University Press, 1980.

—. "The Politics of Pageantry.” In The Collected Papers of Muriel Bradbrook. Brighton: Harvester, 1982-89. Vol. 4, 95-109.

- The Rise of the Common Player. New York: Cambridge University Press, 1962.

Brathwaite, Richard. “The Ape of Fashion.” An Excellent Piece of Conceipted Poetry. London: 1658.

—. The English Gentleman (1630). New York: W. J. Johnson, 1975.

—. The English Gentlewoman (1631). New York, Da Capo Press, 1970.

Braudel, Fernand. Capitalism and Material Life, 1400-1800. Trans. Miriam Kochan. London: Fontana/Collins, 1974.

Braunmuller, A. R. “'To the Globe I rowed': John Holles Sees A Game at Chess.” English Literary Renaissance 20:2 (1991): 340-56.

Brenner, Robert. Merchants and Revolution: Commercial Change, Political Conflict, and London Overseas Traders 1550-1653. Princeton, N.J.: Princeton University Press, 1993.

Brett-James, N. G. The Growth of Stuart London. London: Allen \& Unwin, 1935.

Brittin, Norman A. Thomas Middleton. New York: Twayne, 1972.

Brooke, Iris. English Costume in the Age of Elizabeth. London: A. \& C. Black, Ltd., 1933.

Brooks, Cleanth. The Well Wrought Urn: Studies in the Structure of Poetry. New York: Harcourt, Brace \& World, 1947.

Bruster, Douglas. Drama and the Market in the Age of Shakespeare. Cambridge: Cambridge University Press, 1992. 
Buck, Anne. Clothes and the Child: A Handbook of Children's Dress in England 1500-1900. New York: Holmes \& Meier, 1996.

Burke, Peter. Popular Culture in Early Modern Europe. Rev. ed. London: Scholar Press/Ashgate Publishing, 1994.

Burns, E. Jane. Courtly Love Undressed: Reading Through Clothes in Medieval French Culture. Philadelphia: University of Pennsylvania Press, 2002.

Canny, Nicholas. "The Permissive Frontier: The Problem of Social Control in English Settlements in Ireland and Virginia 1550-1650.” In The Westward Enterprise: English activities in Ireland, the Atlantic, and America 1480-1650, edited by K. R. Andrews, N. P. Canny, and P. E. H. Hair. Liverpool: Liverpool University Press, 1979. 17-44.

Capp, Bernard. "Separate Domains? Women and Authority in Early Modern England." In The Experience of Authority in Early Modern England, edited by P. Griffiths, A. Fox, and S. Hindle. Basingstoke: Macmillan, 1996.

Carlin, Norah. The Causes of the English Civil War. Malden, Massachusetts: Blackwell, 1999.

Carlson, Marvin, ed. Theatre Semiotics: Signs of Life. Bloomington: Indiana University Press, 1990.

Carson, Neil. A Companion to Henslowe's Diary. Cambridge: Cambridge University Press, 1988.

Cavanagh, John. British Theatre: A Bibliography 1901-1985. Mottisfont: Motley Press, 1989.

Cerasano, Susan P. “'Borrowed Robes,' Costume Prices, and the Drawing of Titus Andronicus.” Shakespeare Studies 22 (1994): 45-57.

Chakravorty, Swapan. Society and Politics in the Plays of Thomas Middleton. Oxford: Clarendon Press, 1996.

Chamberlain, John. The Chamberlain Letters. Edited by Elizabeth McClure Thomson. New York: G. P. Putnam’s Sons, 1965.

Chambers, E. K. The Elizabethan Stage. 4 vols. Oxford: Clarendon Press, 1923.

— . "The First Illustration to Shakespeare." The Library, 4th Series, V (1925): 326-30. 
- Notes on the History of the Revels Office Under the Tudors. London: A. H. Bullen, 1906.

Chapman, George, Ben Jonson, and John Marston. Eastward Ho. edited by R. W. Van Fossen. Baltimore: Johns Hopkins University Press, 1979.

Charney, Maurice. “Hamlet without Words.” English Literary History 32 (1965): 457-77.

Clark, Alice. The Working Life of Women in the Seventeenth Century. London: Routledge and Sons, 1919; rpt. London: Frank Cass, 1968.

Clark, Cumberland. Shakespeare and Costume. London: Mitre Press, 1937.

Clark, Peter, and Paul Slack. English Towns in Transition 1500-1700. Oxford: Oxford University Press, 1976.

Clay, Christopher G. A. Economic Expansion and Social Change: England, 15001700. 2 vols. Cambridge: Cambridge University Press, 1984.

Cogswell, Thomas. "Thomas Middleton and the Court, 1624: A Game at Chess in Context.” Huntington Library Quarterly 47:4 (1984): 273-88.

Cole, Mary Hill. The Portable Queen: Elizabeth I and the Politics of Ceremony. Amherst: University of Massachusetts Press, 1999.

Collinson, Patrick. The Elizabethan Puritan Movement. London: Cape, 1967.

Corbett, M., and M. Norton. Engraving in England in the Sixteenth and Seventeenth Centuries. Cambridge: 1964.

Cox, John D. The Devil and the Sacred in English Drama, 1350-1642. Cambridge: Cambridge University Press, 2000.

Cox, John D., and David Scott Kastan, eds. A New History of Early English Drama. New York: Columbia University Press, 1997.

Craik, T. W. The Tudor Interlude: Stage Costume, and Acting. Leicester: Leicester University Press, 1958.

Crane, Susan. The Performance of Self: Ritual, Clothing, and Identity During the Hundred Years War. Philadelphia: University of Pennsylvania Press, 2002.

Cressy, David. Birth, Marriage, and Death: Ritual, Religion, and the Life-Cycle in Tudor and Stuart England. Oxford: Oxford University Press, 1997. 
_. "Describing the Social Order in Early Modern England." Literature and History 3 (1976): 29-44.

_. "Gender and Cross-Dressing in Early Modern England.” Journal of British Studies 35, no. 4 (October 1996): 438-65.

Cumming, Valerie. Exploring Costume History, 1500-1900. London: Batsford Academic and Educational, 1981.

- Royal Dress, the Image and the Reality 1580 to the Present Day. London: B. T. Batsford, 1989.

—. A Visual History of Costume: The Seventeenth Century. London: Drama Book Publishers, 1984.

Cunnington, C. Willett, and Phillis Cunnington. Handbook of English Costume in the Seventeenth Century. London: Faber and Faber, 1954.

Cunnington, C. Willett, Phillis Cunnington, and Charles Beard, eds. A Dictionary of English Costume. 1960.

Cunningham, Phillis. Costume of Household Servants from the Middle Ages to 1900. London: Adam and Charles Black, 19974. - Medieval and Tudor Costume. London: Faber and Faber, 1968.

Cunningham, Phillis, and Anne Buck. Children's Costume in England: From the Fourteenth to the end of the Nineteenth Century. New York: 1965.

Cunningham, Phillis, and Catherine Lucas. Occupational Costume in England: From the Eleventh Century to 1914. New York: Barnes \& Noble, 1967.

Daly, Peter M. "Shakespeare and the Emblem: The Use of Evidence and Analogy in Establishing Iconographic and Emblematic Effects in the Plays.” In Shakespeare and the Emblem: Studies in Renaissance Iconography and Iconology, edited by Tibor Fabiny. Papers in English and American Studies, 3. Szeged: Department of English, Attila Jozsef University, 1984: 117-87.

Daniel, Howard, ed. Callot's Etchings. New York: Dover, 1974.

Davenport, Millia. The Book of Costume. 2 vols. New York: Crown, 1948.

Davidson, Clifford. "Iconography and Some Problems of Terminology in the Study of the Drama and Theatre of the Renaissance." Research Opportunities in Renaissance Drama 29 (1986-87): 7-14. 
- Illustrations of the Stage and Acting in England to 1580. Kalamazoo, Mich.: Medieval Institute Publications, 1991.

—. Technology, Guilds, and Early English Drama. Kalamazoo, Mich.: Medieval Institute Publications, 1996.

Davidson, Clifford, ed. Word, Picture, and Spectacle. Kalamazoo, Mich.: Medieval Institute Publications, 1984.

Dawson, Anthony B., and Paul Yachnin. The Culture of Playgoing in Shakespeare's England: A Collaborative Debate. Cambridge: Cambridge University Press, 2001.

De Grazia, Margreta, Maureen Quilligan, and Peter Stallybrass, eds. Subject and Object in Renaissance Culture. Cambridge: Cambridge University Press, 1996.

Dekker, Rudolf M., and Lotte C. van der Pol. The Tradition of Female Transvestism in Early Modern Europe. London: Macmillan, 1988.

Dekker, Thomas. Satiro-Mastix, or the vntrussing of the Humorous Poet. London: 1602. Edited by Hans Sherer. Louvain: Uystpruyst, 1907.

—. The Seven Deadly Sinnes of London. London: 1606.

—. The Shoemaker's Holiday. edited by Anthony Parr. New York: W W Norton, 1990.

—. The Wonderful Year, The Gull's Hornbook, Penny-Wise, Pound-Foolish, English Villanies Discovered by Latern and Candlelight, and Selected Writings, edited by E. D. Pendry. London: Edward Arnold, 1967.

De Marly, Diana. Costume on the Stage, 1600-1940. London: B. T. Batsford, 1982.

Demaubus, Thierry, “'Momentary visions of permanence' in the Stuart Masque or the Eloquence of Speech through Picture.” Connotations 10 (2000): 268-86.

Dessen, Alan C. Elizabethan Stage Conventions and Modern Interpreters. Cambridge: Cambridge University Press, 1984.

—. Recovering Shakespeare's Theatrical Vocabulary. Cambridge: Cambridge University Press, 1995.

Dessen, Alan C., and Leslie Thomson. A Dictionary of Stage Directions in English Drama, 1580-1642. Cambridge: Cambridge University Press, 1999. 
Dillon, Janette. "Fashion, Nation and Theatre in Late Sixteenth-Century London.” In Shakespeare and His Contemporaries in Performance, edited by Edward J. Esche. Aldershot, England: Ashgate, 2000. 161-76.

- Theatre, Court and City, 1595-1610. Cambridge: Cambridge University Press, 2000.

Dock, Stephen Varick. Costume and Fashion in the Plays of Jean-Baptiste Molière: A Seventeenth Century Perspective. Geneva: Editions Slatkine, 1992.

Dolan, Frances E. “Taking the Pencil Out of God's Hands: Art, Nature, and FacePainting in Early Modern England.” PMLA 108 (1993): 224-39.

Dollerup, Cay. "Danish Costume on the Elizabethan Stage.” Review of English Studies, no. 25 (1974): 53-58.

Dollimore, Jonathan. "Early Modern: Cross-Dressing in Early Modern England.” In Sexual Dissidence: Augustine to Wilde, Freud to Foucault. Oxford: Oxford University Press, 1991.

_. "Subjectivity, Sexuality, and Transgression: The Jacobean Connection." Renaisance Drama, no. 17 (1986): 53-81.

Donald, Moira and Linda Hurcombe, eds. Gender and Material Culture in Historical Perspective. New York: St. Martin’s Press, 2000.

Donne, John. “Satire IV.” In The Satires, Epigrams, and Verse Letters, edited by W. Milgate. Oxford: Clarendon Press, 1967.

Downer, Alan S. “The Life of Our Design.” Hudson Review 2 (1949): 242-63.

Drakakis, John. “'Fashion It Thus’: Julius Caesar and the Politics of Theatrical Representation.” Shakespeare Survey 44 (1992): 65-73; reprinted in Materialist Shakespeare: A History, edited by Ivo Kamps. London: Verso, 1995: 280-291.

Drake, Nathan. Shakespeare and His Times. 2 vols. London, 1817.

Drew-Bear, Annett. “Face-Painting in Renaissance Tragedy.” Renaissance Drama, no. 12 (1981): 71-93.

Dunlevy, Mairead. Dress in Ireland. New York: Holmes and Meier, 1989.

Dutton, Richard. Mastering the Revels. Iowa City: University of Iowa Press, 1991. 
ed. Jacobean Civic Pageants. Keele University/Ryburn Publishing, 1995.

E. T. The Lawes Resolution of Womens Rights. London: 1632.

Egan, Gabriel. "Ariel's Costume in the Original Staging of The Tempest.” Theatre Notebook 51, no. 2 (1997): 62-72.

Elam, Keir. The Semiotics of Theatre and Drama. New York : Menthuen, 1980.

Elias, Norbert. The History of Manners (1939): Volume One of The Civilizing Process. Trans. Edmund Jephcott. New York, 1978.

Elliott, John R., Jr. “Early Staging in Oxford.” In A New History of Early English Drama, edited by John D. Cox and David Scott Kastan. New York: Columbia University Press, 1997. 68-76.

Erickson, Amy Louise. Women and Property in Early Modern England. London: Routledge, 1993.

Erickson, Peter and Clark Hulse, eds. Early Modern Visual Culture. Philadelphia: University of Pennsylvania Press, 2000.

Ezell, Margaret J. M. The Patriarch's Wife: Literary Evidence and the History of the Family. Chapel Hill: University of North Carolina Press, 1987.

Fabiny, Tibor, ed. Shakespeare and the Emblem: Studies in Renaissance Iconography and Iconology. Papers in English and American Studies, 3. Szeged:

Department of English, Attila Jozsef University, 1984.

Farr, Dorothy M. Thomas Middleton and the Drama of Realism. New York: Harper \& Row, 1973.

Ferguson, Arthur B. The Chivalric Tradition in Renaissance England. Cranbury, N.J.: Associated University Presses, 1986.

Ferguson, Margaret W., Maureen Quilligan, and Nancy J. Vickers, eds. Rewriting the Renaissance: The Discourses of Sexual Difference in Early Modern Europe. Chicago: University of Chicago Press, 1986.

Finke, Laurie A. "Painting Women: Images of Femininity in Jacobean Tragedy." Theatre Journal 36 (1984): 357-70.

Finlay, Roger. Population and Metropolis: The Demography of London, 1580-1650. Cambridge: Cambridge University Press, 1981. 
Fisher, Frederick Jack. "The Development of London as a Centre of Conspicuous Consumption in the Sixteenth and Seventeenth Centuries." Transactions of the Royal Historical Society, 4th series, 30 (1948): 37-50; reprinted in London and the English Economy, edited by P. J. Corfield and N. B. Harte. London: The Hambledon Press, 1990): 105-18.

- London and the English Economy, 1500-1700, edited by P. J. Corfield and N. B. Harte. London: Hambledon Press, 1990.

— ed. Essays in the Economic and Social History of Tudor and Stuart England in Honour of R. H. Tawney. Cambridge: Cambridge University Press, 1961.

Fisher, Will. "The Renaissance Beard: Masculinity in Early Modern England.” Renaissance Quarterly 54 (2001): 155-82.

Fitzgeffrey, Henry. Satyres: And Satyricall Epigram's: With Certain Observations at Black-Fryers (1617). London: Miles Patrick, 1986.

Fleay, Frederick Gard. A Chronicle of the London Stage, 1559-1642. New York: Burt Franklin, 1890.

Foakes, R. A. Illustrations of the English Stage, 1580-1642. Stanford, Calif.: Stanford University Press, 1985.

Forse, James H. Art Imitates Business: Commercial and Political Influences in Elizabethan Theatre. Bowling Green, Ohio: Bowling Green University Press, 1993.

Frazer, Winifred L. “King Lear’s ‘Good Block.’” Shakespeare Quarterly 28 (1977): $354-55$.

Freudenberger, Herman. "Fashion, Sumptuary Laws and Business.” In Fashion Marketing: An Anthology of Viewpoints and Perspectives, edited by Gordon Wills and David Midgley. London: George Allen \& Unwin, 1973.

Friedenreich, Kenneth, ed. "Accompaninge the Players": Essays Celebrating Thomas Middleton, 1580-1980. New York: AMS Press, 1983.

Friedrichs, Christopher R. The Early Modern City, 1450-1750. London: Longman, 1995.

Friis, Astrid. Alderman Cockayne's Project and the Cloth Trade: The Commercial Policy of England in Its Main Aspects, 1603-1625. London: Oxford University Press, 1927. 
Frye, Susan, and Karen Robertson, eds. Women's Alliances in Early Modern England. Oxford: Oxford University Press, 1999.

Fuller, Thomas. The Worthies of England. 1662. Edited by John Freeman. London: Allen and Unwin, 1952.

Fumerton, Patricia. Cultural Aesthetics: Renaissance Literature and the Practice of Social Ornament. Chicago: University of Chicago Press, 1991.

Garber, Majorie. Vested Interests: Cross-Dressing and Cultural Anxiety. New York: Routledge, 1992.

. "The Logic of the Trasvestite: The Roaring Girl." In Staging the Renaissance, edited by David Scott Kastan and Peter Stallybrass. New York: Routledge, 1991. 221-34.

Garner, Shirley Nelson. “'Let Her Paint an Inch Thick’: Painted Ladies in Renaissance Drama and Society.” Renaissance Drama 20 (1989): 123-39.

Gent, Lucy, and Nigel Llewellyn, eds. Renaissance Bodies: The Human Figure in English Culture, c. 1540-1660. London: Reaktion Books, 1990.

Gibson, Joy Leslie. Squeaking Cleopatras: The Elizabethan Boy Player. Phoenix Mill, Gloucestershire: Sutton Publishing, 2000.

Gilbert, Allan H. The Symbolic Persons in the Masques of Ben Jonson. Durham, NC: Duke University Press, 1948.

Glanville, Philippa. “The City of London.” In The Cambridge Guide to the Arts in Britain, edited by Boris Ford, 165-77. Volume 4: The Seventeenth Century. Cambridge: Cambridge University Press, 1989.

Gordon, D. J. and Jean Robertson. Malone Society Collections III. Oxford: Oxford University Press, 1954.

Gosson, Stephen. The Schoole of Abuse. Edited by Edward Arber. London: Murray and Son, 1868.

Gowing, Laura. Domestic Dangers: Women, Words, and Sex in Early Modern London. Oxford: Clarendon Press, 1996.

Graves, R. B. Lighting the Shakespearean Grave, 1567-1642. Carbondale: Southern Illinois University Press, 1999.

Gras, Henk. Studies in Elizabethan Audience Response to the Theatre, 2 vols. New 
York: P. Lang, 1993.

Greenblatt, Stephen. Learning to Curse: Essays in Early Modern Culture. New York: Routledge, 1990.

—. Renaissance Self-Fashioning. Chicago: University of Chicago Press, 1980.

—. "Resonance and Wonder.” In Learning to Curse. New York: Routledge, 1990. 161-83.

—. Shakespearean Negotiations. Berkeley: University of California Press, 1988.

Greg, W. W. Dramatic Documents from the Elizabethan Playhouses. 2 vols. Oxford: Oxford University Press, 1931.

Grendler, Paul F., and Margaret L. King. Women of the Renaissance. Chicago: University of Chicago Press, 1991.

Gurr, Andrew. Playgoing in Shakespeare’s London. 2d ed. Cambridge: Cambridge University Press, 1996.

—. The Shakespearian Playing Companies. Oxford: Oxford University Press, 1996.

- The Shakespearean Stage, 1574-1642. 3d ed. Cambridge: Cambridge University Press, 1992.

Gurr, Andrew, and Mariko Ichikawa. Staging in Shakespeare's Theatre. Oxford: Oxford University Press, 2000.

Hall, Kim F. "Sexual Politics and Cultural Identity in The Masque of Blackness.” In The Performance of Power: Theatrical Discourse and Politics, edited by SueEllen Case and Janelle Reinelt. Iowa City: University of Iowa Press, 1991. 318.

- Things of Darkness: Economies of Race and Gender in Early Modern England. Ithaca: Cornell University Press, 1995.

Hall, Marcia B. Color and Meaning: Practice and Theory in Renaissance Painting. New York: Cambridge University Press, 1992.

Hancock, David. Citizens of the World: London Merchants and the Integration of the British Atlantic Community. Cambridge: Cambridge University Press, 1996.

Happé, Peter. English Drama before Shakespeare. New York: Longman, 1999. 
Harben, Henry A. A Dictionary of London. London: Herbert Jenkins, 1908.

Harding, Vanessa. "The Population of London, 1550-1700: A Review of the Published Evidence.” London Journal 15 (1990): 111-28.

Harner, James. Literary Research Guide. $3^{\text {rd }}$ ed. New York: MLA Publications, 1998. ed. The World Shakespeare Bibliography on CD-ROM. Cambridge: Cambridge University Press, 1996-present.

Harris, John, and Gordon Jiggott. Inigo Jones: Complete Architectural Drawings. London: Philip Wilson, 1989.

Harrison, William. The Description of England. edited by Georges Edelen. Ithaca: Cornell University Press, 1968.

Harte, N. B. "State Control of Dress and Social Change in Pre-Industrial England." In Trade, Government and Economy in Pre-Industrial England: Essays to F. J. Fisher, edited by D. C. Coleman and A. H. John. London: Weidenfeld \& Nicolson, 1976. 132-65.

Harte, N. B., and K. G. Ponting, eds. Cloth and Clothing in Medieval Europe: Essays in Memory of Professor E. M. Carus-Wilson. London: Heinemann, 11983.

- Textile History and Economic History: Essays in Honour of Miss Julia de Lacy Mann. Manchester: Manchester University Press, 1973.

Hattaway, Michael. Elizabethan Popular Theatre. London: Routledge, 1982.

Hazard, Mary E. Elizabethan Silent Language. Lincoln: University of Nebraska Press, 2000.

Heinemann, Margot. “Middleton’s A Game at Chess: Parliamentary-Puritans and Opposition Drama.” English Literary Renaissance 5 (1975): 232-50.

—. Puritanism and Theatre: Thomas Middleton and Opposition Drama Under the Early Stuarts. New York: Cambridge University Press, 1980.

Heller, Scott. "A Fresh Look at a Cryptic Drawing Puts Titus Andronicus in a New Light.” The Chronicle of Higher Education 4 June 1999, Section A19.

Henderson, Katherine Usher, and Barbara F. McManus, eds. Half Humankind: Contexts and Texts of the Controversy about Women in England, 1540-1640. Urbana: University of Illinois Press, 1985. 
Henslowe, Philip. Henslowe's Diary, $2^{\text {nd }}$ ed., edited by R. A. Roakes. Cambridge: Cambridge University Press, 2002.

Herbert, Sir Henry. The Dramatic Records of Sir Henry Herbert, Master of the Revels 1623- 1673. Edited by Joseph Quincy Adams. New Haven, Conn.: Yale University Press, 1917.

Highley, Christopher and John N. King, eds. John Foxe and His World. Burlington, VT: Ashgate, 2002.

Hillebrand, Harold Newcomb. The Child Actors. New York: Russell \& Russell, 1964.

Hilliard, Nicholas. A Treatise Concerning the Arte of Limning (c. 1615). Edited by R. K. R. Thornton and T. G. S. Cain. Manchester: Carcanet Press, 1992.

Hind, Arthur M. Engravings in England in the Sixteenth \& Seventeenth Centuries. 3 vols. Cambridge: Cambridge University Press, 1952, 1955, 1964.

Hinds, Allen B., ed. Calendar of State Papers, Venetian, vol. 15. London: Longman, Green, Longman, Roberts, and Green,1909.

Hodges, C. Walter. Enter the Whole Army: A Pictorial Study of Shakespearean Staging 1576-1616. New York: Cambridge University Press, 1999.

Hoenselaars, A. J. Images of Englishmen and Foreigners in the Drama of Shakespeare and His Contemporaries: A Study of Stage Characters and National Identity in English Renaissance Drama 1558-1642. Toronto: Associated University Press, 1992.

Hole, Christina. English Home-Life, 1500-1800. London: Hutchinson, 1976.

Hollander, Anne. Fabric of Vision: Dress and Drapery in Painting. London: National Portrait Gallery, 2002.

—. Seeing Through Clothes. New York: Viking Penguin, 1978.

—. Sex and Suits. New York : Kodansha International, 1995.

Holmes, Martin. “An Unrecorded Portrait of Edward Alleyn.” Theatre Notebook 5 (1950): 11-13.

Honigmann, E. A. J. “'There is a World Elsewhere’: William Shakespeare, Businessman.” In Images of Shakespeare, edited by Werner Habicht, D. J. Palmer, and Roger Pringle. Newark: University of Delaware Press, 1988. 
Hooper, Wilfred. “The Tudor Sumptuary Laws.” English Historical Review 20 (1915): 433-49.

Hope, Valerie. My Lord Mayor: Eight Hundred Years of London’s Mayorality. London: Weidenfeld and Nicolson, 1989.

Hotson, Leslie. The Commonwealth and Restoration Stage. Cambridge, Mass.: Harvard University Press, 1928.

Howard, Edwin Johnston, ed. Pleasant Quippes for Vpstart Newfangled Gentlewomen. Oxford, OH: Anchor Press, 1942.

Howard, Jean E. The Stage and Social Struggle in Early Modern England. New York: Routledge, 1994.

Howard, Skiles. The Politics of Courtly Dancing in Early Modern England. Amherst: University of Massachusetts Press, 1998.

Howard-Hill, T. H. Middleton's "Vulgar Pasquin”: Essays on A Game at Chess. Newark: University of Delaware Press, 1995.

Howarth, David. Lord Arundel and His Circle. New Haven, Conn.: Yale University Press, 1985.

—. "Merchants and Diplomats: New Patrons of the Decorative Arts in Seventeenth Century England.” Furniture History 20 (1984): 10-17.

Hudson, Kenneth. Pawnbroking: An Aspect of British Social History. London: The Bodley Head, 1982.

Hufton, Olwen. The Prospect Before Her: A History of Women in Western Europe, 1500-1800. New York: A. Knopf, 1996.

Hughes, Paul L., and James F. Larkin. Tudor Royal Proclamations. 3 vols. New Haven, Conn.: Yale University Press, 1964-69.

Hull, Suzanne W. Chaste, Silent \& Obedient: English Books for Women 1475-1640. San Marino, Calif.: Huntington Library, 1982.

Hunter, G. K. "Flatcaps and Bluecoats: Visual Signals on the Elizabethan Stage.” Essays and Studies 33 (1980): 16-47.

Hutton, Henry. Follies Anatomie: or Satyres and Satyricall Epigrams (1619). London: Reprinted for the Percy Society, 1842. 
Ingram, Martin. Church Courts, Sex, and Marriage in England 1570-1640.

Cambridge: Cambridge University Press, 1987.

Ingram, William. The Business of Playing: The Beginnings of Adult Professional Theater in Elizabethan London. Ithaca, N.Y.: Cornell University Press, 1992.

Inwood, S. A History of London. London: Macmillan, 1998.

Jack, S. M. Trade and Industry in Tudor and Stuart England. London: Allen \& Unwin, 1977.

Jack, Sybil. "The Revels Accounts: This insubstantial pageant faded leaves not a wrack behind?” Renaissance Studies 9 (1995): 1-17.

Jacquot, Jean, and Elige Konigston, eds. Les Fêtes de la Renaissance. 3 vols. Paris: Éditions du C.N.R.S., 1956-75.

James I. James I, The Political Works. Edited by Charles Howard McIlwain. New York: Russell and Russell, 1965.

James, Norman G. Brett. The Growth of Stuart London. London: G. Allen \& Unwin, 1935.

Janssen, Carole A. “The Waytes of Norwich and an Early Lord Mayor’s Show.” Research Opportunities in Renaissance Drama 22 (1979): 57-64.

Lisa Jardine. Still Harping on Daughters. Totowa, N.J.: Barnes \& Noble, 1983.

- Still Harping on Daughters: Women and Drama in the Age of Shakespeare. Totowa, N.J.: Barnes \& Noble, 1983.

- Worldly Goods: A New History of the Renaissance. New York: Nan A. Talese, 1996.

Jaster, Margaret Rose. "Fashioninge the Minde and Condicions: The Uses and Abuses of Apparel in Early Modern England.” Ph.D. diss., University of Maryland, College Park, 1994.

Jones, Ann Rosalind. "Dematerializations: Textile and Textual Properties in Ovid, Sandys, and Spencer.” In Subject and Object in Renaissance Culture, edited by Margreta de Grazia, Maureen Quilligan, and Peter Stallybrass. Cambridge: Cambridge University Press, 1996. 189-212.

- Maids and Mistresses: Cousins and Queens: Women's Alliances in Early Modern England. 1999. 
Jones, Ann Rosalind, and Peter Stallybrass. Renaissance Clothing and the Materials of Memory. Cambridge: Cambridge University Press, 2001.

. “'Rugges of London and the Diuell's Band': Irish Mantles and Yellow Starch as Hybrid London Fashion.” In Material London, ca. 1600, edited by Lena Cowen Orlin. Philadelphia: University of Pennsylvania Press, 2000. $128-49$.

Jones, D. W. “The 'Hallage' Receipts of the London Cloth Markets 1562-c. 1720.” Economic History Review, 2nd series, 25 (1972): 567-87.

Jones, Norman. “Shakespeare’s England.” In A Companion to Shakespeare, edited by David Scott Kastan. Oxford: Blackwell, 2000: 25-42.

Jonson, Ben. Five Plays. Edited by G. A. Wilkes. New York: Oxford University Press, 1981.

—. Ben Jonson's Literary Criticism. Edited by James D. Redwine, Jr. Lincoln: University of Nebraska Press, 1970.

- The New Inn. Ben Jonson. Edited by C. H. Herford, Evelyn Simpson, and Percy Simpson. Oxford: Clarendon Press, 1938.

—. Poetaster, Ben Johnson. Edited by C. H. Herford, Evelyn Simpson, and Percy Simpson. Oxford: Clarendon Press, Vol. 4, 3.4.197-98.

Jowers, Sidney, and John Cavanagh. Theatrical Costume, Masks, Make-Up and Wigs: A Bibliography and Iconography. New York: Routledge, 2000.

Kastan, David Scott. “Is There a Class in This (Shakespearean) Text?” Renaissance Drama 25 (1993): 101-21; reprinted in Political Shakespeare, edited by Stephen Orgel and Sean Keilen. New York: Garland Publishing, 1999. 1-22.

Kastan, David Scott and Peter Stallybrass. Staging the Renaissance:

Reinterpretations of Elizabethan and Jacobean Drama. New York: Routledge, 1991.

Kelly, Francis M. Shakespearian Costume. Revised by Alan Mansfield. New York: Theatre Arts Books, 1970.

Kelly, Francis M., and Randolph Schwabe. European Costume and Fashion: 14901790. New York: Scribner, 2002.

. Historic Costume: A Chronicle of Fashion in Western Europe. Salem, NH: Ayer Company, 1929. 
Kerridge, Eric. Textile Manufactures in Early Modern England. Manchester: Manchester University Press, 1985.

Kesler, Jackson. Theatrical Costume: A Guide to Information Sources. Detroit: Gale Research, 1979.

King, Donald, and Santina Levey. The Victoria and Albert Museum's Textile Collection: Embroidery in Britain from 1200 to 1750. London: Victoria and Albert Museum, 1993.

King, John N. Tudor Royal Iconography. Princeton, N.J.: Princeton University Press, 1989.

King, T. J. “The First Known Picture of Falstaff (1662): A Suggested Date for His Costume.” Theatre Research International 3 (1977): 19-22.

Kinney, Arthur F. Shakespeare by Stages: An Historical Introduction. Malden, MA: Blackwell, 2003.

Kinney, Arthur F., and David M. Swain, eds. Tudor England: An Encyclopedia. New York: Garland, 2000.

Kipling, Gordon. “Triumphal Drama: Form in English Civic Pageantry.” Renaissance Drama new series 8 (1977): 37-56.

Klein, Lisa M. "Your Humble Handmaid: Elizabethan Gifts of Needlework.” Renaissance Quarterly 50 (1997): 459-93.

Knowles, James. “Cecil’s Shopping Centre.” Times Literary Supplement, 7 February 1997: 14-15.

—_. “Jonson’s Entertainment at Britain’s Burse.” In Representing Ben Jonson, edited by Martin Butler. London: Macmillan, 1999. 114-51.

_. "The Spectacle of the Realm: Civic Consciousness, Rhetoric and Ritual in Early Modern London.” In Theatre and Government Under the Stuarts, edited by J. R. Mulryne and Margaret Shewring. Cambridge: Cambridge University Press, 1993. 157-89.

Knutson, Roslyn L. The Repertory of Shakespeare's Company, 1594-1613. Fayetteville: University of Arkansas Press, 1991.

Kolin, Philip C., and R. O. Wyatt, III. “A Bibliography of Scholarship on the Elizabethan Stage Since Chambers.” Research Opportunities in Renaissance Drama 15-16 (1972-73): 33-59. 
Komisarjevsky, Theodore. The Costume of the Theatre. New York: Benjamin Blom, 1968.

Korda, Natasha. "Household Kates: Domesticating Commodities in The Taming of the Shrew.” Shakespeare Quarterly 47.2 (1996): 109-31.

_ . "Houshold Property/State Property: Henslowe as Pawnbroker." Theatre Journal 48 (1996): 185-96.

- Shakespeare's Domestic Economies: Gender and Property in Early Modern England. Philadelphia: University of Pennsylvania Press, 2002.

Korda, Natasha, and Jonathan Gill Harris, eds. Staged Properties: Props and Properties in Early Modern Drama. New York: Cambridge University Press, 2002.

Lamar, Virginia A. English Dress in the Age of Shakespeare. Washington, D.C.: Folger Shakespeare Library, 1958.

Laver, James. The Concise History of Costume and Fashion. New York: Harry N. Abrams, 1969.

—. Costume in the Theatre. New York: Hill and Wang, 1964. ed. Costume of the Western World: Fashions of the Renaissance. New York: Harper and Brothers, 1951.

Lee, Jr., Maurice, ed. Dudley Carlton to John Chamberlain 1603-1624. New Brunswick, N.J.: Rutgers University Press, 1972.

Leggatt, Alexander. Jacobean Public Theatre. London: Routledge, 1992.

Leinwand, Theodore B. "London Triumphing: The Jacobean Lord Mayor's Show.” CLIO 11:2 (1982): 137-53.

Lemire, Beverly. Dress, Culture and Commerce: The English Clothing Trade before the Factory, 1660-1800. London: Macmillan, 1997.

Levin, Carole. The Heart and Stomach of a King: Elizabeth I and the Politics of Sex and Power. Philadelphia: University of Pennsylvania Press, 1994.

. “'We Princes, I Tell You, Are Set on Stages': Elizabeth I and Dramatic SelfRepresentation.” In Readings in Renaissance Women's Drama: Criticism, History, and Performance, 1594-1998, edited by S. P. Cerasano and Marion Wynne-Davies. New York: Routledtge, 1998. 
Levin, Richard. "The Economics and Erotics of Cross-Class Dressing in Early Modern (formerly Renaissance) English Drama." Journal of Theatre and Drama 3 (1997): 93-101.

Levine, Laura. "Men in Women's Clothing: Anti Theatricality and Effeminization from 1579-1642." Criticism 28, no. 2 (1986): 121-43.

- Men in Women's Clothing: Anti-theatricality and Effeminization, 15791642. Cambridge: Cambridge University Press, 1994.

Lewalski, Barbara K. "Lucy, Countess of Bedford: Images of a Jacobean Courtier and Patroness.” In The Politics of Discourse, edited by Kevin Sharpe and Stephen Zwicker. Berkeley: University of California Press, 1987. 52-77.

Lindley, David. "Embarrassing Ben: The Masques for Frances Howard.” English Literary Renaissance 16, no. 2 (1986): 343-59.

- The Trials of Frances Howard: Fact and Fiction at the Court of King James. London: Routledge, 1993.

Lindley, David, ed. Court Masques. Manchester: Manchester University Press, 1984.

Linthicum, Marie Channing. Costume in the Drama of Shakespeare and His Contemporaries. Oxford: Clarendon, 1936.

Lipson, E. A Short History of Wool and Its Manufacture. London: Heinemann, 1953.

Llewellyn, Nigel. The Art of Death: Visual Culture in the English Death Ritual c. 1500- c. 1800. London: Reaktion Books, 1991.

Loads, David, ed. John Foxe: An Historical Perspective. Brookfield: Ashgate, 1999.

Lobanov-Rostovsky, Sergei. "The Triumphs of Golde: Economic Authority in the Jacobean Lord Mayor’s Show.” ELH 60 (1993): 879-98.

Lodge, Edmund. Illustrations of British History. London: J. Chidley, 1838.

Lopez, Robert. "The Dawn of Medieval Banking.” In The Dawn of Modern Banking. New Haven, Conn.: Yale University Press, 1979.

Luborsky, Ruth Samson and E. Ingram. A Guide to English Illustrated Books 15361603, 2 vols. Tempe, Arizona: Medieval \& Renaissance Texts \& Studies, 1998.

Lunney, Ruth. Marlowe and the Popular Tradition. New York: Manchester 
University Press, 2002.

Lusardi, James P. and Henk Gras. “Abram Booth’s Eyewitness Account of the 1629 Lord Mayor’s Show.” Shakespeare Bulletin 11 (1993): 19-23.

Lytle, Guy Fitch, and Stephen Orgel, eds. Patronage in the Renaissance. Princeton, N.J.: Princeton University Press, 1981.

MacIntyre, Jean. Costumes and Scripts in the Elizabethan Theatres. Edmonton: University of Alberta Press, 1992.

MacIntyre, Jean, and Garrett P. J. Epp. “'Cloathes worth all the rest': Costumes and Properties.” In A New History of Early English Drama, edited by John D. Cox and David Scott Kastan. New York: Columbia University Press, 1977. 269_ 86.

MacLean, Ian. The Renaissance Notion of Women: A Study in the Fortunes of Scholasticism and Medical Science in European Intellectual Life. Cambridge: Cambridge University Press, 1980.

Manley, Lawrence. Literature and Culture in Early Modern London. Cambridge: Cambridge University Press, 1995.

— Pennsylvania State University Press, 1986.

Markham, Gervase. The English Hus-wife. London: 1615, 1631. Edited by Michael Best. Montreal: McGill-Queen’s University Press, 1986.

Marlowe, Christopher. Tamburlaine edited by J. S. Cunningham. New York: Manchester University Press, 1981.

Marly, Diana de. Costume on the Stage, 1600-1940. Totowa, NJ: Barnes \& Noble, 1982.

Marly, Diana de. Working Dress: A History of Occupational Clothing. London: B. T. Batsford, 1986.

Marshall, Rosalind. Costume in Scottish Portraits 1560-1830. Edinburgh: Scottish National Portrait Gallery, 1986.

Mauss, Marcel. The Gift: Forms and Functions of Exchange in Archaic Societies. Trans. Ian Cunnison. New York: Norton, 1967.

McCoy, Richard C. The Rights of Knighthood: The Literature and Politics of Elizabethan Chivalry. Berkeley: University of California Press, 1989. 
McCracken, Grant. "Dress Colour at the Court of Elizabeth I: An Essay in Historical Anthropology." Canadian Review of Sociology and Anthropology 22 (1985): 515-33.

McGee, C. E., and John C. Meagher. "Preliminary Checklist of Tudor and Stuart Entertainments: 1558-1603.” Research on Renaissance Drama 24 (1981): $51-155$.

__ . "Preliminary Checklist ... 1485-1558." Research on Renaissance Drama 25 (1982): 31-114

_ . "Preliminary Checklist .. . 1603-1613.” Research on Renaissance Drama 27 (1984): 47-126.

_. "Preliminary Checklist ... 1614-1625." Research on Renaissance Drama 30 (1988): 17-128.

McMillin, Scott. The Elizabethan Theatre and "The Book of Sir Thomas More". Ithaca, N.Y.: Cornell University Press, 1987.

McMillin, Scott and Sally-Beth Maclean. The Queen's Men and Their Plays. Cambridge: Cambridge University Press, 1998.

Meads, Chris. Banquets Set Forth: Banqueting in English Renaissance Drama. Manchester: Manchester University Press, 2002.

Meagher, John C. “The London Lord Mayor’s Show of 1590.” English Literary Renaissance 3 (1973): 94-104.

Mellencamp, Emma Hirsch. Renaissance Classical Costume, 1450-1515. Ann Arbor, Mich.: 1956.

Mercer, Eric. Elizabethan Art: 1553-1625. Oxford: 1962.

Merchant, W. Moelwyn. "Classical Costume in Shakespearean Productions.” Shakespeare Survey 10 (1957): 71-76.

Mertes, Kate. The English Noble Household 1250-1600: Good Governance and Political Rule. Oxford: Blackwell, 1988.

Middleton, Thomas. A Game at Chesse. edited by R. C. Bald. New York: Cambridge University Press, 1929.

—. A Game at Chess. edited by T. H. Howard-Hill. New York: Manchester University Press, 1993. 
—. Your Five Gallants. London: Richard Bonian, 1608.

Middleton, Thomas and William Rowley. The World Tost at Tennis. London: George Purslowe, 1620.

Millar, Oliver. The Age of Charles I: Painting in England 1620-1649. London: Tate Gallery, 1972.

- The Tudor, Stuart, and Early Georgian Pictures in the Collection of H. M. the Queen. London: Phaidon Press, 1977.

Miller, Daniel. Material Culture and Mass Consumption. Oxford: Blackwell, 1987.

Milton, Roger. The English Ceremonial Book. Newton Abbot: David and Charles, 1972.

Minchinton, W. E. The Growth of English Overseas Trade in the Seventeenth and Eighteenth Centuries. London: Methuen, 1969.

Mirkin, Ronnie. "Performing Selfhood: The Costumed Body as a Site of Mediation Between Life, Art and Theatre in the English Renaissance." In Body Dressing, edited by Joanne Entwistle and Elizabeth Wilson. New York: Berg, 2001. 143-64.

Mowat, Barbara A. “'The Getting Up of the Spectacle': The Role of the Visual on the Elizabethan Stage, 1576-1600.” In The Elizabethan Theatre IX, edited by G. R. Hibbard. Ontario: P. D. Meany, 1981. 60-76.

Mowl, Timothy. Elizabethan and Jacobean Style. London: Phaidon Press,1993.

Mullaney, Steven. "Mourning and Misogyny: Hamlet, The Revenger's Tragedy, and the Final Progress of Elizabeth I, 1600-1607." Shakespeare Quarterly 45 (1994): 139-62.

Mulryne, J. R. and Margaret Shewring, eds. Theatre and Government under the Early Stuarts. New York: Cambridge University Press, 1993.

Mumby, Frank A. The Girlhood of Queen Elizabeth: A Narrative in Contemporary Letters. Boston: Houghton Mifflin Co., 1910.

Munns, Jessica and Penny Richards. The Clothes That Wear Us: Essays on Dressing and Transgressing in Eighteenth-Century Culture. Newark: University of Delaware Press, 1999.

Murrell, V. J. “The Art of Limning.” Artists of the Tudor Court: The Portrait 
Miniature Rediscovered 1520-1620. Edited by Roy Strong. London: Victoria and Albert Museum catalogue, 1983.

Nakayama, Randall. “'I know she is a courtesan by her attire’: Clothing and Identity in The Jew of Malta.” In Marlowe's Empery: Expanding His Critical Contexts, edited by Sara Munson Deats and Robert A. Logan. Newark: University of Delaware Press, 2002. 150-63.

Nelson, Alan H., ed. Records of Early English Drama: Cambridge. Toronto: University of Toronto Press, 1989.

Nevinson, J. L. “Shakespeare’s Dress in His Portraits.” Shakespeare Quarterly 18 (1967): 101-6.

Newman, Karen. Fashioning Femininity and English Renaissance Drama. Chicago: University of Chicago Press, 1991.

Newton, Stella Mary. Renaissance Theatre Costume and the Sense of the Historic Past. London: Rapp and Whiting, André Deutsch, 1975.

Niccols, Richard. Thomas Overburies Vision. 1616. London: The Hunterian Club, 1873.

Nichols, John Gough, ed. The Diary of Henry Machyn. New York: AMS Press, 1968.

Nicoll, Allardyce. Stuart Masques and the Renaissance Stage. New York: Benjamin Blom, 1938.

Nicolls, John. The Progresses, Processions, and Magnificent Festivities of King James I. 3 vols. London: Society of Antiquarians, 1828.

Norris, Herbert. Costume and Fashion. 3 vols. New York: E. P. Dutton, 1927-38.

Nunn, Joan. Fashion in Costume, 1200-2000. London : Herbert Press, 1984.

O’Connor, Michael. “The Idolatrous Eye: Iconoclasm, Anti-Theatricalism, and the Image of the Elizabethan Theatre.” ELH 52 (1985): 279-310.

Ogden, Dunbar H. “Costume Change in the Liturgical Drama.” Early Drama, Art, and Music Review 21 (1999): 80-88.

_ . "Costumes and Vestments in the Medieval Music Drama.” In Material Culture and Medieval Drama, edited by Clifford Davidson. Kalamazoo, Mich.: Medieval Institute Publications, 1998. 1-57.

—. The Staging of Drama in the Medieval Church. Newark: University of 
Delaware Press, 2002.

Oldridge, Darren. Religion and Society in Early Stuart England. Brookfield: Ashgate, 1998.

Olian, Jo Anne. “Sixteenth-Century Costume Books.” Dress 3 (1977): 20-48.

Orgel, Stephen. “The Authentic Shakespeare.” Representations 21 (Winter 1988): 125.

"Gendering the Crown.” In Subject and Object in Renaissance Culture, edited by Margreta de Grazia, Maureen Quilligan, and Peter Stallybrass. Cambridge: Cambridge University Press, 1996. 133-65.

—. The Illusion of Power. Berkeley: University of California, 1975.

- Impersonations: The Performance of Gender in Shakespeare's England. Cambridge: Cambridge University Press, 1996.

—. "Jonson and the Amazons.” In Soliciting Interpretations: Literary Theory and Seventeenth-Century English Poetry, edited by Elizabeth D. Harvey and Katharine Eisaman Maus. Chicago: University of Chicago Press, 1990. 11939 .

—. The Jonsonian Masque. Cambridge, Mass.: Harvard University Press, 1965.

_. "Making Greatness Familiar.” In The Power of Forms in the English Renaissance, edited by Stephen Greenblatt. Norman, Okla.: Pilgrim Books, 1982.

—_. "Marginal Jonson.” In The Politics of the Stuart Court Masque, edited by David Bevington and P. Holbrook. Cambridge: Cambridge University Press, 1998. 144-75.

Orgel, Stephen and Roy Strong. Inigo Jones: The Theatre of the Stuart Court. 2 vols. Berkeley: University of California Press, 1973.

Orgel, Stephen and Sean Keilen, eds. Shakespeare and the Arts. New York: Garland, 1999.

Orlin, Lena Cowen. Private Matters and Public Culture in Post-Reformation England. Ithaca, N.Y.: Cornell University Press, 1994.

— Press, 2000. 
Orrell, John. “Antimo Galli’s Description of the The Masque of Beauty.” Huntington Library Quarterly 43 (1979): 13-23.

_ . "The London Stage in the Florentine Correspondence.” Theatre Research International 3 (1978): 157-76.

Outhwaite, R. B., ed. Marriage and Society: Studies in the Social History of Marriage. London: Europa, 1981.

Overbury, Sir Thomas. A wife now the widow of Sir T. Overbury... Whereunto are added many witty characters. London: A. Crooke, 1638.

Patterson, Annabel. Shakespeare and the Popular Voice. Oxford: Blackwell, 1989.

Peck, Linda Levy. "Building, Buying, and Collection in London, 1600-1625.” In Material London, c. 1600, edited by Lena Cowen Orlin. Philadelphia: University of Pennsylvania Press, 2000. 268-89.

Peck, Linda Levy, ed. The Mental World of the Jacobean Court. Cambridge: Cambridge University Press, 1991.

Percy, C. H. Herford and Evelyn Simpson. Ben Jonson. vol. 10. Oxford: Clarendon Press, 1954.

Pick, Richard. "The Worthy Ladies of Hardwick Hall.” Theatre History Studies 13 (1993): 115-34.

Platter, Thomas. Thomas Platter's Travels in England, 1599. Trans. and edited by Clare Williams. London: Jonathan Cape, 1937.

Pomeroy, Elizabeth W. Reading the Portraits of Queen Elizabeth I. Hamden, Conn: Archon Books, 1989.

Porter, Roy. London, A Social History. London: Hamish Hamilton, 1994.

Postlewait, Thomas. "From Event to Context to Event: A Problem in the Writing of Theatre History.” In Critical Theory and Performance, eds. Janelle Reinelt and Joseph Roach. Ann Arbor: University of Michigan Press, forthcoming 2003.

Potter, Robert. "The Cardinal's New Clothes: Politics and Morality in the 1520s." Research Opportunities in Renaissance Drama 31 (1992): 61-63.

Power, M. J. "London and the Control of the 'Crisis' of the 1590s." History 70 (1985): 371-85. 
_ . "A 'Crisis' Reconsidered: Social and Economic Dislocation in London in the 1590s.” London Journal 12 (1986): 134-45.

Press, Wilfred R., ed. The Professions in Early Modern England. London: Croom Helm, 1987.

Pressly, William L. Catalogue of Paintings in the Folger Shakespeare Library. New Haven, Conn.: Yale University Press, 1993.

Prior, Mary, ed. Women in English Society 1500-1800. London: Methuen, 1985.

Prockter, Adrian, and Robert Taylor. The A to Z of Elizabethan London. Lympne Catle, Kent: Harry Margary in association with the Guildhall Library, 1979.

Prynn, William. Histrio-Mastix (1633), 2 vols. New York: Johnson Reprint Corp., 1972.

- Documents Relating to the Proceedings against William Prynne. Edited by Samuel Rawson Gardiner. London: Camden Society, vol. 18, 1877.

—. The Unloveliness of Lovelockes (1628). Norwood, N.J.: W. J. Johnson, 1976.

Rackin, Phyllis. "Androgyny, Mimesis, and the Marriage of the Boy Heroine on the English Renaissance Stage.” PMLA 102 (1987): 29-41.

Rainoldes, John. Th’ Overthrow of Stage-Playes. London: 1599.

Ramsay, G. D. The City of London in International Politics at the Accession of Elizabeth Tudor. Manchester: Manchester University Press/Rowman and Littlefield, 1975.

__ "Cloth Workers, Merchant Adventures and Richard Hakluyt.” English Historical Review 92: 504-22.

—. "The Undoing of the Italian Mercantile Colony in Sixteenth-Century London.” In Textile History and Economic History: Essays in Honour of Miss Julia de Lacy Mann, edited by N. B. Harte and K. G. Point. Manchester: Manchester University Press, 1973. 22-49.

Rappaport, Steven. Worlds within Worlds: Structures of Life in Sixteenth-Century London. Cambridge: Cambridge University Press, 1989.

Reay, Barry. Popular Culture in Seventeenth-Century England. London: Croom Helm, 1985. 
Reynolds, Graham. “Elizabethan and Jacobean 1558-1625.” In Costume of the Western World, edited by James Laver. London: George G. Harrap, 1951. 127-88.

Reid, Aileen, and Robert Maniura, eds. Edward Alleyn: Elizabethan Actor, Jacobean Gentleman. London: Dulwich Picture Gallery, 1995.

Rich, Barnabe. The Honestie of this Age. London: 1614.

- The Irish Hubbub, or the English Hue and Crie. London: 1618.

Richards, R. D. The Early History of Banking in England. London: Frank Cass, 1958.

Richardson, George. Iconology, London 1779. 2 vols. New York: Garland, 1979.

Riewald, J. G. "The English Actors in the Low Countries, 1585-c. 1650: An Annotated Bibliography.” In Studies in Seventeenth Century English Literature, History, and Bibliography, edited by G. A. M. Janssens and F. G. A. M. Aarts. Amsterdam, 1984. 157-78.

Roche, Daniel. The Culture of Clothing: Dress and Fashion in the "Ancien Régime," translated by Jean Birrell. Cambridge: Cambridge University Press, 1994.

Rose, Mary Beth. “Women in Men’s Clothing: Apparel and Social Stability in The Roaring Girl.” English Literary Renaissance 14 (1984): 367-91.

Russell, Douglas. "Mannerism and Shakespearean Costume.” Educational Theatre Journal 16 (1964): 324-32.

Russell, Conrad, ed. The Origins of the English Civil War. London: Macmillan, 1973.

Russell, Jocelyne G. The Field of Cloth of Gold: Men and Manners in 1520. London: Routledge and Kegan Paul, 1969.

Rutter, Carol Chillington. Documents of the Rose Playhouse. Rev. ed. Manchester: Manchester University Press, 1999.

Rye, W. B. England as Seen by Foreigners in the Days of Elizabeth and James the First. London: John Russell Smith, 1865.

Schlueter, June. "Rereading the Peacham Drawing.” Shakespeare Quarterly 50 (1999): 171-84.

. “A Tragic Misunderstanding.” TLS 19 February 1999: 16. 
Schneider, Jane. “The Anthropology of Cloth.” Annual Review of Anthropology 16 (1987): 409-48.

. "Fantastical Colors in Foggy London: The New Fashion Potential of the Late Sixteenth Century.” In Material London, ca. 1600, edited by Lena Cowen Orlin. Philadelphia: University of Pennsylvania Press, 2000. 109-27.

_ . "Peacocks and Penguins: The Political Economy of European Cloth and Colors.” American Ethnologist 5 (1978): 413-38.

Schuman, Samuel. "Emblems and the English Renaissance Drama: A Checklist." Research Opportunities in Renaissance Drama 12 (1969): 43-56.

Scott, William. An Essay on Drapery, or The Complete Citizen. London: Printed by Eli All-de, for Stephen Pernell, 1635.

Seaver, Paul S. Wallington's World: A Puritan Artisan in Seventeenth-Century London. Stanford, Calif.: Stanford University Press, 1985.

Shapiro, James. Shakespeare and the Jews. New York: Columbia University Press, 1996.

Shapiro, Michael. Children of the Revels: The Boy Companies of Shakespeare's Time and Their Plays. New York: Columbia University Press, 1977.

- Gender in Play on the Shakespearean Stage: Boy Heroines and Female Pages. Ann Arbor: University of Michigan Press, 1994.

Sharpe, J. A. Crime in Early Modern England 1550-1750. London: Longman, 1984.

—. Early Modern England: A Social History 1500-1700. London: E. Arnold, 1987.

Shaw, Henry. Dress and Decoration of the Middle Ages. Cobb, California: First Glance Books, 1998.

Slack, Paul. Poverty and Policy in Tudor and Stuart England. London: Longman, 1988.

Smith, David L., Richard Strier, and David Bevington, eds. The Theatrical City: Culture, Theater, and Politics in London, 1576-1649. Cambridge: Cambridge University Press, 1995.

Smith, Hal H. "Some Principles of Elizabethan Stage Costume." Journal of the Warburg and Courtauld Institutes 25 (1962): 240-57. 
Smuts, R. Malcolm. Court Culture and the Origins of a Royalist Tradition in Early Stuart England. Philadelphia: University of Pennsylvania Press, 1987.

— . "Public Ceremony and Royal Charisma: The English Royal Entry in London, 1485-1642.” In The First Modern Society: Essays in History in Honour of Lawrence Stone, edited by A. L. Beier, David Cannadine, and James M. Rosenheim. Cambridge: Cambridge University Press, 1989. 65-93.

Southern, Richard. The Staging of Plays before Shakespeare. London: Faber \& Faber, 1973.

Sparke, Michael. Truth Brought to Light and Discovered by Time, or A Discourse and Historicall Narration of the first XIIII yeares of King Iames Reigne. London: Michael Sparke, 1651.

Spufford, Margaret. The Great Reclothing of Rural England: Petty Chapman and Their Wares in the Seventeenth Century. London: Hambledon Press, 1984.

Stallybrass, Peter. "Patriarchal Territories: The Body Enclosed.” In Rewriting the Renaissance, edited by M. Ferguson, M. Quilligan, and N. J. Vickers. Chicago: University of Chicago Press, 1986. 123-42.

_. "Worn Worlds: Clothes and Identity on the Renaissance Stage.” In Subject and Object in Renaissance Culture, edited by M. De Grazia, M. Quilligan, and P. Stallybrass. Cambridge: Cambridge University Press, 1996. 289-320.

—_ "Worn Worlds: Clothes, Mourning, and the Life of Things.” In Cultural Memory and the Construction of Identity, edited by Dan Ben-Amos and Liliane Weissberg. Detroit: Wayne State University Press, 1999. 27-44.

Stephenson, Henry Thew. Shakespeare’s London. New York: Henry Holt, 1905.

Stevens, David. English Renaissance Theatre History: A Reference Guide. Boston: G. K. Hall, 1982.

Stewart, Horace. History of the Worshipful Company of Gold and Silver WyreDrawers. London: The Leadenhall Press, 1891.

Stina-Ewbank, Inga. "More Pregnantly Than Words: Some Uses and Limitations of Visual Symbolism.” Shakespeare Survey 24 (1971): 13-18.

Stone, Lawrence. The Family, Sex, and Marriage in England 1500-1800. New York: Harper \& Row, 1977.

Stoughton, Thomas. The Christians Sacrifice. London: William Iones, 1622. 
Stow, John. The Survey of London. London: 1598, 1603. 2 vols. Edited by Charles Lethbridge Kingsford. Oxford: Clarendon Press, 1908.

- Annales of England. Continued by Edmund Howes. London: Richard Meighen, 1632.

Streitberger, W. R. Court Revels 1485-1559. Toronto: University of Toronto Press, 1994.

_. "Financing Court Entertainments, 1509-1558." Research Opportunities in Renaissance Drama 27 (1984): 21-45.

—. Malone Society Collections XIII. Oxford: Oxford University Press, 1986.

__ "Renaissance Revels Documents." Research Opportunities in Renaissance Drama 21 (1978): 11-16.

—. "The Revels at Court from 1541 to 1559.” Research Opportunities in Renaissance Drama 29 (1986-87): 25-45.

Strong, Roy. Art and Power: Renaissance Festivals, 1450-1650. Berkeley: University of California Press, 1984.

- The Cult of Elizabeth: Elizabethan Portraiture and Pageantry. Berkeley: University of California Press, 1977.

- The Elizabethan Image: Painting in England 1540-1620. London, The Tate Gallery, 1969.

—. The English Icon. New Haven, Conn.: Yale University Press, 1969.

—. English Renaissance Miniature. Ashton-upon-Lyne, Lancashire: Thames \& Hudson, 1983.

- Henry, Prince of Wales, and England's Lost Renaissance. London: Thames \& Hudson, 1986.

- Gloriana: The Portraits of Queen Elizabeth I. London: Thames, and Hudson, 1987.

—. Portraits of Queen Elizabeth I. Oxford: Clarendon Press, 1963.

- Splendor at Court: Renaissance Spectacle and the Theater of Power. Boston: Houghton Mifflin, 1973. 
—. Tudor and Jacobean Portraits. 2 vols. London: H. M. S. O., 1969.

Strong, Roy, and V. J. Murrell. Artists of the Tudor Court: The Portrait Miniature Rediscovered 1520-1620. London: Victoria and Albert Museum, 1983.

Stubbes, Phillip. The Anatomie of Abuses. 1583. Edited by Frederick J. Furnivall. The New Shakespeare Society, series 6, no. 4. London: Trubner, 1877-79.

Sturgess, Keith. Jacobean Private Theatre. New York: Routledge \& Kegan Paul, 1987.

Styan, J. L. Shakespeare’s Stagecraft. Cambridge: Cambridge University Press, 1967.

Sullivan, Mary. Court Masques of James I. New York: G. P. Putnam’s Sons, 1913.

Supple, Barry. Commercial Crisis and Change in England 1600-42: A Story in the Instability of a Mercantile Economy. Cambridge: Cambridge University Press, 1959.

Tawney, R. H. “The Rise of the Gentry, 1558-1640.” Economic History Review 11 (1941): 1-38.

Tawney, R. H., and Eileen Power, eds. Tudor Economic Documents: Being Select Documents Illustrating the Economic and Social History of Tudor England. 3 vols. London: Longman’s Green, 1965.

Teague, Francis. Shakespeare’s Speaking Properties. Lewisburg, Pa.: Bucknell University Press, 1991.

Thirsk, Joan. Economic Policy and Projects: The Development of a Consumer Society in Early Modern England. Oxford: Clarendon Press, 1978.

_. "The Fantastical Folly of Fashion: The English Stocking Knitting Industry, 1500-1700.” In Textile History and Economic History, edited by N. B. Hart and K. G. Pointing. Manchester: Manchester University Press, 1973. 50-74.

Thomson, Leslie. "The Meaning of Thunder and Lightning: Stage Directions and Audience Expectations.” Early Theatre (forthcoming).

Thomson, Peter. Shakespeare's Professional Career. Cambridge: Cambridge University Press, 1992.

Tickner, F. W. Women in English Economic History. London: Dent, 1923.

Tomkis, Thomas. Albumasar: A Comedy. Edited by Hugh G. Dick. Berkeley: 
University of California Press, 1944.

Tortora, Phyllis, and Keith Eubank. Survey of Historic Costume. 3d ed. New York: Fairchild Publications, 1998.

Trevor-Roper, H. R. The Gentry, 1540-1640: Economic History Review Supplement, I. Cambridge: Cambridge University Press, 1953.

Tuke, Thomas. A Treatise against Painting and Tincturing of Men and Women. London: 1616.

Tumbleson, Raymond D. “The Triumph of London: Lord Mayor's Day Pageants and the Rise of the City.” In The Witness of Times: Manifestations of Ideology in Seventeenth Century England, edited by Katherine Z. Keller. Pittsburgh, PA: Duquesne University Press, 1993. 53-68.

Twycross, Meg, and Sarah Carpenter. "Masks in Medieval English Theatre: The Mystery Plays.” Medieval English Theatre 3 (1981): 7-44, 69-113.

_. "Materials and Methods of Mask-making." Medieval English Theatre 4 (1982): 28-47.

Vecellio, Cesare. Vecellio’s Renaissance Costume Book. New York: Dover, 1977.

Venezky, Alice S. [Alice Griffin]. Pageantry on the Shakespearean Stage. Boston: Twayne, 1951.

Wagner, Eduard, Zoroslav Drobna, and Jan Durdik. Medieval Costume, Armour, and Weapons. New York: Dover, 2000.

Wallace, Charles William. Globe Theatre Apparel. London: for the author, 1909.

Walton, Penelope. “Textiles.” In English Medieval Industries: Craftsmen, Techniques, Products, edited by John Blair and Nigel Ramsay. London: Hambledon Press, 1991.

Waterhouse, E. K. Painting in Britain, 1530-1790. London: Penguin, 1953.

Watt, Teresa. Cheap Print and Popular Piety, 1550-1640. Cambridge: Cambridge University Press, 1991.

Weatherill, Lorna. Consumer Behaviour and Material Culture in Britain, 1660-1760. London: Routledge, 1988.

Webster, Tom. Godly Clergy in Early Stuart England. New York: Cambridge University Press, 1997. 
Wedel, Lupold Von. “Journey Through England and Scotland Made by Lupold Von Wedel in the Years 1584 and 1585," translated by Gottfried Von Bülow. Transactions of the Royal Historical Society, new series 9 (1895): 223-70.

Weinmann, Robert. Shakespeare and the Popular Tradition in the Theater: Studies in the Social Dimension of Dramatic Forms and Function. Edited by Robert Schwartz. Baltimore: Johns Hopkins University Press, 1978.

Weinstein, Rosemary. Tudor London. London: HMSO, 1994.

Weisner, Merry. "Spinsters and Seamstresses: Women in Cloth and Clothing Production.” In Rewriting the Renaissance: The Discourses of Sexual Difference in Early Modern Europe, edited by Margaret Ferguson, Maureen Quilligan, and Nancy Vickers. Chicago: Chicago University Press, 1986.

Wells, E. A. The British Hosiery and Knitwear Industry, Its History and Organization. New York: Barnes \& Noble, 1972.

Wells, Stanley, ed. Shakespeare: A Bibliographical Guide. New edition. Oxford: Clarendon Press, 1990.

Wells-Cole, Anthony. Art and Decoration in Elizabethan and Jacobean England. New Haven, Conn.: Yale University Press, 1997.

Whigham, Frank. Ambition and Privilege: The Social Tropes of Elizabethan Courtesy Theory. Berkeley: University of California Press, 1984.

Wickham, Glynne. Early English Stages. 3 vols. in 4 parts. New York: Columbia University Press, 1959-1972; reprinted, revised edition, 3 vols. in 5 parts: New York: Routledge, 2002.

Wickham, Glynne, Herbert Berry, and William Ingram, eds. English Professional Theatre, 1530-1660. Theatre in Europe: A Documentary History. Cambridge: Cambridge University Press, 2000.

Wilde, Oscar. “Shakespeare and Stage Costume.” Nineteenth Century (May 1885): 800-818; republished as "The Truth of Masks" in various collections of Wilde’s essays.

Williams, Clare. Thomas Platter's Travels in England, 1599. London: Jonathan Cape, 1959.

Williams, George Walton. "Second Thoughts on Lear's 'Good Block.'” Shakespeare Quarterly 29 (1978): 421-22. 
Wilson, Charles. "Cloth Production and International Competition in the Seventeenth Century.” Economic History Review, 2nd series, 13 (1960): 209-21.

Wilson, F. P. Malone Society Collections Volume X. Oxford: Oxford University Press, 1977.

Wilson, J. Dover. Life in Shakespeare’s England. 2d ed. Cambridge: Cambridge University Press, 1926.

Wilson, Richard. “'A Mingled Yarn’: Shakespeare and the Clothes Workers.” Literature and History 12 (1986): 164-80.

Wilson, Robert. An Edition of Robert Wilson's Three Ladies of London and Three Lords and Three Ladies of London. edited by H. S. D. Mithal. New York: Garland, 1988.

Wilson, Violet. Society Women of Shakespeare's Time. Port Washington, N.Y.: Kennikat Press, 1970.

Withington, Robert. English Pageantry: An Historical Outline. 2 vols. Cambridge, Mass.: Harvard University Press, 1918, 1920; republished: New York: B. Blom, 1963.

Wright, Louis B. Middle-Class Culture in Elizabethan England. Chapel Hill: University of North Carolina Press, 1935.

Wrightson, Keith. English Society 1580-1680. London: 1981; New Brunswick, N.J.: Rutgers University Press, 1982.

Yachnin, Paul. “A Game at Chess and Chess Allegory.” SEL: Studies in English Literature 22 (1982): 317-30.

_. "A Game at Chess: Thomas Middleton's 'Praise of Folly."” Modern Language Quarterly 48:2 (1987): 107-23.

Yarwood, Doreen. English Costume from the Second Century B.C. to 1950. London: B. T. Batsford, 1952.

Young, Alan. Tudor and Jacobean Tournaments. London: George Philip, 1987.

Young, K. “William Gager's Defence of the Academic Stage.” Transactions of the Wisconsin Academy of Sciences, Arts, and Letters 18 (1916): 593-638.

Zimmerman, Susan. "Disruptive Desire: Artifice and Indeterminacy in Jacobean Comedy.” In Erotic Politics, edited by Susan Zimmerman. New York: 
Routledge, 1992. 39-63.

Zimmerman, Susan, and Ronald F. E. Weisman, eds. Urban Life in the Renaissance. Newark: University of Delaware Press, 1989. 